UNIVERSIDADE DE SÃO PAULO

ESCOLA DE COMUNICAÇÕES E ARTES

Vera Cristina Sgambato Cury

RELAÇÕES ENTRE A NEUROCIÊNCIA E O ENSINO E APRENDIZAGEM DAS ARTES PLÁSTICAS 
Vera Cristina Sgambato Cury

\title{
RELAÇÕES ENTRE A NEUROCIÊNCIA E O ENSINO E APRENDIZAGEM DAS ARTES PLÁSTICAS
}

\begin{abstract}
Dissertação apresentada à Área de Concentração: Artes Plásticas da Escola de Comunicações e Artes da Universidade de São Paulo, como exigência parcial para a obtenção do título de Mestre em Artes, sob a orientação da Profa. Dra. Regina Stela Barcelos Machado
\end{abstract}


AUTORIZO A REPRODUÇÃO E DIVULGAÇÃO TOTAL OU PARCIAL DESTE TRABALHO, POR QUALQỦER MEIO CONVENCIONAL OU ELETRÔNICO, PARA FINS DE ESTUDO E PESQUISA, DESDE QUE CITADA A FONTE.

\section{Catalogação na Publicação \\ Serviço de Biblioteca e Documentação \\ Escola de Comunicações e Artes da Universidade de São Paulo}

\begin{tabular}{|l} 
Cury, Vera Cristina Sgambato. \\
Relações entre a neurociência e o ensino e aprendizagem das \\
artes plásticas / Vera Cristina Sgambato Cury. São Paulo: V. C. S. \\
Cury, 2007. \\
236 p. \\
Dissertação (Mestrado) - Escola de Comunicações e \\
Artes/USP, 2007. \\
Orientadora: Machado, Regina Stela Barcelos. \\
Bibliografia \\
1.Arte 2. Ensino e aprendizagem 3. Percepção 4. Neurociência \\
5. Cognição 6. Imaginação I. Machado, Regina Stela Barcelos II. \\
Título. \\
CDD 21 ed. 707.7
\end{tabular}




\section{FolHA DE APROVAÇÃO}

Vera Cristina Sgambato Cury

Relações entre a neurociência e

o ensino e aprendizagem das artes plásticas

Dissertação apresentada à Escola de Comunicações e Artes da Universidade de São Paulo, para a obtenção do título de Mestre em Artes. Área de Concentração: Artes Plásticas.

Aprovada em:

\section{Banca Examinadora}

Prof. Dr :

Instituição:

Assinatura:

Prof. Dr :

Instituição:

Assinatura:

Prof. Dr :

Instituição:

Assinatura:

São Paulo 
Para você... Naturalmente! 


\section{AGRADECIMENTOS}

"Cada um que passa em nossa vida, passa sozinho, pois cada pessoa é única e nenhuma substitui outra. Cada um que passa em nossa vida, passa sozinho, mas não vai só nem nos deixa sós. Leva um pouco de nós mesmos, deixa um pouco de si mesmo. Há os que levam muito, mas há os que não levam nada. Essa é a maior responsabilidade de nossa vida, e a prova que duas almas não se encontram ao acaso." Antoine de Saint-Exupéry

Agradeço a preciosa participação de todos os colaboradores deste trabalho, em especial:

a minha orientadora, Regina Machado, que esteve sempre atenta a minha caminhada, incentivando-me a cada descoberta;

ao Marcus Vinícius C. Baldo e à Maria Christina de Souza Lima Rizzi, pela aprendizagem no momento da Qualificação;

ao diretor do Instituto de Ciências Biomédicas da USP, Luiz Roberto Giorgetti de Britto, e ao chefe do Departamento de Fisiologia, Rui Curi;

ao prof. Luiz Eduardo Ribeiro do Valle, pelo respeito com que me acolheu em suas aulas, reuniões e em seu laboratório;

aos professores do Curso de Mestrado;

à Rhowena Matos, pela amizade, apoio constante e parceria em diversos trabalhos.

à Márcia Higuchi Kodama, pela valiosa e inestimável colaboração ao ler e comentar o texto;

aos amigos Altiere Carvalho, Camila Bruder, Klebert Toscano, Luiz Lana, Roberta Areas e Vivian Guedes, por toda a atenção em ouvir, ler e discutir esta pesquisa; 
aos companheiros do Departamento de Fisiologia e Biofísica do Instituto de Ciências Biomédicas da USP que muito me têm ensinado na prática cotidiana e nas reflexões continuadas sobre Arte, Ciência e Vida;

às revisoras Ana Claudia Dantas Ferreira e Rita de Sousa, sempre atentas à cada detalhe;

ao meu filho, Daniel Cury, à minha família e amigos que souberam compreender minhas ausências e colaborar com minhas descobertas. 


\section{RESUMO}

CURY, Vera Cristina Sgambato. Relações entre a neurociência e o ensino e aprendizagem das artes plásticas. 2007. 236f. Dissertação (Mestrado). Escola de Comunicações e Artes, Universidade de São Paulo, São Paulo, 2007.

Esse trabalho busca estabelecer relações entre a neurociência e o ensino e aprendizagem da arte, mantendo o foco nas artes plásticas. Desse modo o ato de desenhar, observar, perceber e imaginar, exercidos na ação artística, são considerados a partir do funcionamento do sistema nervoso. O conhecimento de como o encéfalo funciona pode dar subsídios importantes para futuras formulações metodológicas da área.

Palavras-chave: 1. Arte; 2. Ensino e aprendizagem; 3. Percepção; 4. Neurociência; 5. Cognição; 6. Imaginação. 


\section{ABSTRACT}

CURY, Vera Cristina Sgambato. Relations between neuroscience and the teaching and learning of plastic arts. 2007. 236f. Dissertation (Master's degree). School of Communication and Arts. University of São Paulo, São Paulo, 2007.

This work seeks to establish relations between neuroscience and the teaching and learning of art, having plastic arts as main focus. This way the act of drawing, observing, interpreting and imagining are considered from the functioning of the nervous system. The knowledge of how the nervous system, mainly the brain, works may provide important subsidies for future methodological formulations in the area.

Key-words: 1. Art; 2. Arts Education; 3. Perception; 4. Neuroscience; 5.Imagination;

6. Cognition 


\section{SUMÁRIO}

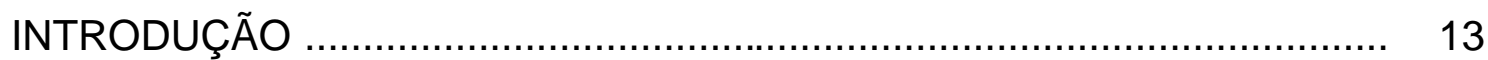

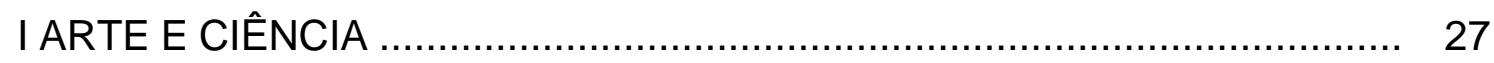

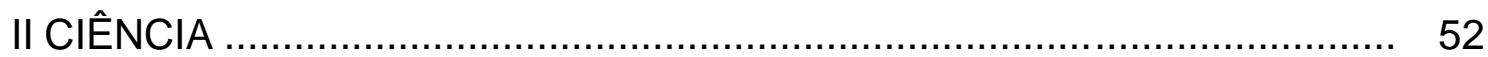

2.1 Imaginando o funcionamento do sistema nervoso ............................... 52

2.1.1 A organização do sistema nervoso e processamento da informação neural 55

2.1.2 Neurônios-espelho ..................................................................... 62

2.1.3 Emoção e o sistema límbico ........................................................... 66

2.1.4 Localização encefálica do sistema límbico ………………….......... 66

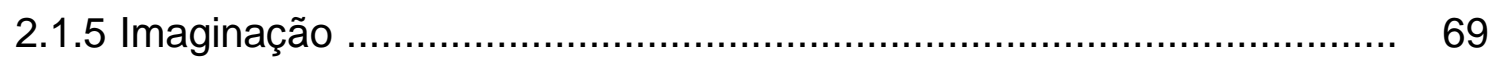

2.2 Percepção, um panorama sensorial ................................................ 74

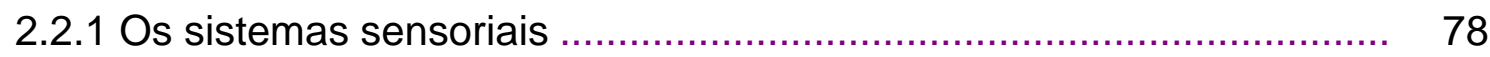

2.3 Memória e aprendizado …………............................................. 94

2.3.1 Plasticidade Neuronal .............................................................. 106

2.3.2 Localização das estruturas encefálicas envolvidas no processamento da memória

2.3.3 A evocação e o esquecimento ..................................................... 109

2.3.4 Enfim, o resumo.................................................................. 111

2.4 Aprendizado e mudança anatômica do córtex cerebral ......................... 112

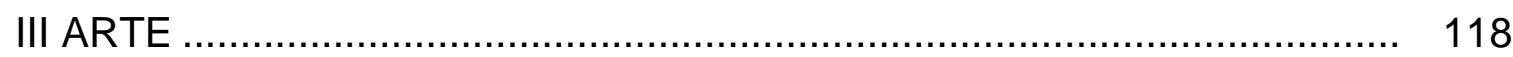

3.1 A arte e a evolução da espécie humana ............................................. 118

3.1.1 Hipóteses de como ocorreu o despertar .......................................... 121 
3.1.2 Origens da arte

3.1.3 Critérios para que os arqueólogos considerem um artefato como arte

3.1.4 Processos cognitivos simbólicos 135

3.1.5 Conclusão 137

3.2 Arte, percepção, observação e cognição 138

3.2.1 Observar 140

3.2.2 A observação, a arte, a ciência e o desenho 143

3.2.3 Observar, perceber, memorizar e imaginar 151

3.3 O ensino e a aprendizagem da arte 152

IV PESQUISAS 164

4.1 Neurociência e educação 164

4.1.1 Aprendizado e neurociência 164

4.1.2 Cooperação entre as áreas 167

4.1.3 Implicações educacionais 170

4.2 Pesquisas relacionadas com arte e neurociência . 173

CONSIDERAÇÕES FINAIS 179

REFERÊNCIAS BIBLIOGRÁFICAS 184

GLOSSÁRIO 194

ANEXOS 207

I HEMISFÉRIO CEREBRAL DIREITO E ESQUERDO ............................... 207

II A PSICOLOGIA EXPERIMENTAL E AS TEORIAS DA GESTALT ........... 218 III SANTIAGO RAMÓN Y CAJAL ............................................ 225

IV LISTA DE ILUSTRAÇÕES .............................................. 234 
"Para uma mente completa,

Estude a arte da ciência,

Estude a ciência da arte,

Aprenda a enxergar,

Perceba que tudo se conecta a tudo".

Leonardo da Vinci 


\section{INTRODUÇÃO}

Quando estava com nove anos de idade, tive a sorte de ter uma professora de arte na escola. A professora Vitória dava apenas aulas de arte e história da arte; ela era especial e especialista em uma só área: ARTE. Ela gostava, conhecia com profundidade e valorizava o que ensinava. No meio em que eu vivia, desenhar era considerado uma habilidade que se adquiria sozinho, se quisesse, era algo secundário e, na maioria das vezes, dispensável.

Que experiência fantástica tive nos dois anos em que fui sua aluna. Hoje, posso dizer que esses dois anos foram tão marcantes que, de certa forma, nortearam a minha escolha profissional. Até hoje me lembro das atividades que realizei em suas aulas: desenhos, pinturas, escultura com papier mâché, modelagem em argila, sempre um novo desafio que os alunos realizavam na classe e em casa. Quando, na aula seguinte, os alunos traziam os trabalhos realizados em casa e expunham para a classe, eu ficava fascinada observando as inúmeras variantes de um mesmo tema. Como era lindo ver o modo único e particular com que cada um expressava suas percepções. Quanta vida a observação daqueles trabalhos me transmitiram e quanto aprendi sobre minha potencialidade, participando das aulas da Professora Vitória.

As aulas de história da arte eram dadas com slides e livros. Aqueles livros grandes, com reprodução das obras de pintores famosos, nos quais ela apontava o tipo de pigmento usado na época, salientava a estilo do artista e habilmente transportava os alunos para um mundo que havia sido criado com a imaginação do artista e poderia ser recriado com a nossa imaginação. 
O tempo passou, os outros professores de arte se sucederam sem deixar marcas profundas. E eu me preparava para ser médica, na verdade queria ser psiquiatra. No colegial, optei pela área das ciências biológicas em período integral, isso significava passar todas as tardes no laboratório, acompanhando o professor na dissecação de animais (rato, sapo, cobra, pomba e peixe) e trabalhando em equipe: realizando experiências, preparando lâminas para serem observadas ao microscópio, desenhando as imagens observadas, discutindo os resultados dos experimentos, preparando relatórios e fazendo provas e mais provas. Meus colegas e eu nos preparávamos para sermos bons médicos, dentistas e farmacêuticos.

Mas, conforme se aproximava a data do vestibular, percebi que não me identificava com aquelas atividades a ponto de torná-las uma profissão. Afinal, os momentos que mais me satisfaziam aconteciam enquanto desenhava e pesquisava toda aquela infinidade de formas, cores e texturas das imagens que observava ao microscópio. Eu queria poder expressar algo mais pessoal, algo que não fosse estritamente descritivo e dedutivo.

Resolvi, nos últimos dois meses que antecediam o vestibular, ingressar no curso de Comunicação Visual. O desafio de prestar as provas na área de humanas, quando na verdade sempre me dediquei às atividades da área de biológicas, foi o de passar pela prova prática: a terrível prova de desenho, que era eliminatória!

Fui aprovada e as matérias que cursei na faculdade eram incríveis: desenho de observação, história da arte, antropologia, sociologia, teorias da comunicação, fotografia, desenho animado, história em quadrinhos, marcenaria, cerâmica, cinema, escultura, xilogravura, gravura em metal, serigrafia, esistência 
das matérias, composição gráfica, desenho geométrico, perspectiva, ergonomia entre outras. Muitas vezes, ao me ver executando os trabalhos em casa, meu pai perguntava: "Mas você está estudando mesmo ou será que tudo isso não é só diversão?" E eu respondia que eu era a pessoa mais feliz do mundo, pois estudava o que, para muitos, era considerado entretenimento. Os estágios que realizei foram na área industrial e gráfica.

Por um tempo fui free-lancer, criando logotipos e realizando a programação gráfica de micro empresas, enquanto cursava minha segunda graduação: Licenciatura Plena em Artes Plásticas. Havia percebido que não me bastava trabalhar com arte, eu queria saber como ensinar arte. Depois de todo esse percurso, me habilitei como Arte Educadora.

$\mathrm{Na}$ jornada rumo à minha profissionalização, busquei sempre atuar com realidades diversas. Assim sendo, atuei com diferentes classes sócioeconômicas, faixas etárias distintas, tanto na rede de ensino particular quanto na rede pública. Em cursos profissionalizantes e em cursos livres realizados no atelier.

Ao mesmo tempo, para que a prática do ensino da arte não se automatize, existem algumas questões que precisam ser sempre reconsideradas: $\mathrm{O}$ que é arte? Arte se ensina? É possível aprender através da arte? O que significa arte para mim? Como propiciar ao aluno uma experiência significativa no ensino da arte? Qual a importância da aprendizagem e do ensino da arte? Qual a qualidade específica da arte?

De etapa em etapa, de formulação em formulação, os passos se sucederam; e após tantos anos eu ainda continuo intrigada ao observar o efeito transformador que a arte é capaz de exercer nas pessoas. Da maneira como os alunos, independentemente da idade ou capacidade cognitiva, são capazes de 
desenvolver uma série de habilidades, muitas vezes diferente do conteúdo que havia sido dado.

Quanto mais me intrigava, mais atentamente observava. Ao dar aulas na periferia de São Paulo, ou mesmo no sertão da Bahia, regiões em que os alunos apresentam vários tipos de carência, desde econômica até nutricional, um fato sempre me chamou a atenção: era a partir das aulas de arte que o conteúdo das outras matérias parecia ser melhor absorvido. Como algo desta natureza é possível? Poderia a arte desenvolver algum tipo peculiar de inteligência?

Acompanhando o trabalho desenvolvido por meus colegas arteeducadores com crianças com dificuldade de alfabetização, adolescentes infratores, idosos em clínica de repouso, adictos internados em clínicas de recuperação, mães de sociedades de bairros, crianças de rua, pacientes em recuperação póstraumática ou mesmo emigrantes em fase de adaptação, observei o modo como públicos tão distintos podiam ser beneficiados com o ensino e aprendizagem da arte.

Mas, como essas coisas acontecem? Como é possível que em situações tão adversas (com poucos recursos de ordem material, nítidas deficiências nutricionais e carências de toda ordem) uma prática adequada de ensino e aprendizagem da arte possa gerar um aprendizado capaz de mobilizar forças que antes pareciam inexistentes?

Ao mesmo tempo em que procurava aprimorar minha prática de ensino, busquei elementos para melhor responder essas questões na filosofia, na psicologia e na pedagogia. Olhar por diferentes ângulos uma mesma questão pode ajudar a compor um entendimento mais abrangente do assunto.

Participando do VI Congresso Brasileiro de Autismo, em julho de 2003, tomei conhecimento de pesquisadores que, em seus trabalhos, estavam utilizando a 
técnica da Ressonância Magnética funcional (RMf), assim como outras técnicas de neuroimagem em suas pesquisas. Com essas técnicas eles avaliaram a atuação da amígdala, localizada no interior do encéfalo, nos estados emocionais.

Ao considerar as características de uma criança autista, que se caracteriza sempre por desvios qualitativos na comunicação, na interação social e no uso da imaginação e os resultados das pesquisas que demonstram o modo como um autista distribui sua atenção visual ao explorar uma imagem, fiquei imaginando: Como poderiam ser as aulas de arte para uma criança autista? Qual seria o resultado da RMf de um autista que tivesse tido aulas de arte, por um determinado período? Será que é possível investigar cientificamente como a ação artística atua no sistema nervoso?

Não se trata de considerar o ensino e aprendizagem da arte como Arte Terapia, mas sim como uma atividade capaz de potencializar o funcionamento cerebral de qualquer indivíduo. Afinal, como funciona o organismo enquanto o indivíduo realiza atividades artísticas (pintura, escultura, dança, música entre outras)?

Pensando nestas possibilidades, comecei a estruturar uma pesquisa, tendo como hipótese: Como o ensino e aprendizagem da arte podem potencializar o funcionamento cerebral?

As três disciplinas que cursei na ECA foram ótimas, aprendi muito no convívio com os professores, os pós-graduandos, o ambiente universitário e, de certa forma, eu me sentia em casa. Percebi que, independente de estar estudando em livros e artigos, os temas relativos à psicologia e neurociência cognitiva, participando dos simpósios de neuropsicologia da aprendizagem, tendo contato freqüente com profissionais que atuam nestas áreas, deveria ampliar meu 
conhecimento do assunto cursando algumas disciplinas oferecidas pelo NEC (Neurociência e Comportamento - Instituto de Psicologia/USP) e BMB (Instituto de Ciências Biomédicas-ICB/USP). Inscrevi-me, então, como aluna regular em três disciplinas: Neurofisiologia básica (BMB); Psicofisiologia da Atenção e da Memória (NEC); e Progressos em Neurofisiologia (BMB).

Com a inscrição concluída fiquei na expectativa de ser aceita. Quais seriam os pré-requisitos exigidos? A secretaria da pós-graduação da ECA não tinha como responder essa questão, aliás, ao ler os títulos das disciplinas selecionadas por mim, sugeriram que eu estava em área errada. As secretarias do NEC e BMB informaram que somente o docente responsável pela disciplina poderia me aceitar ou não.

Fui aceita! Porém todos os professores me preveniram que eu deveria ficar atenta ao prazo de cancelamento da matrícula, pois este era um curso de pósgraduação e o fato de estar numa área tão diferente da minha talvez me trouxesse problemas. Afinal, a avaliação é realizada com provas dissertativas e a maior parte do material a ser estudado são artigos e livros em inglês, mesmo eu tendo proficiência nessa língua, os conceitos já seriam difíceis em português, quanto mais em inglês.

As aulas começaram e logo uma pressão extra apareceu, era uma pressão constante, às vezes delicada, às vezes hostil e muitas vezes sutil, por parte dos professores para que eu cancelasse a matrícula, pois eles não gostariam de me deixar retida, mas de forma alguma seriam condescendentes na avaliação. Sempre frisaram que eu seria muito bem-vinda como aluna ouvinte, afinal esse é o próprio espírito e propósito da Universidade, mas, como aluna regular, meu desempenho deveria apresentar um rendimento compatível ao dos pós-graduandos da fisiologia, 
nutrição, biologia, fonoaudiologia, medicina, educação física, farmácia, psicologia, enfim, as áreas de graduação que predominantemente desenvolvem pesquisas em neurociência.

Das três disciplinas, cancelei a matrícula de apenas uma: Progressos em Neurofisiologia. Mas conversei com o professor e continuei assistindo assiduamente na condição de ouvinte. Muitos dos alunos inscritos cursavam também as mesmas disciplinas, portanto não tardou que esse convívio se estreitasse. Quando eles perceberam que eu levava a sério e estava realmente disposta a estudar e aprender, cada um, a seu modo, sempre me ajudou. Respondiam-me pequenas dúvidas durante as aulas, para que eu não perdesse o fio da meada. Respondiam-me algumas questões após a aula e outras antes das aulas. Eu procurava variar ao máximo a quem perguntar para não exaurir nenhum deles. Por isso, acabei conhecendo melhor a todos, desde a graduação de origem de cada um, sua história de vida, seus sonhos e objetivos, até o modo como cada área ordena os pensamentos para expressar uma resposta.

Depois de dois meses, uma das disciplinas passou a ter carga horária dobrada, nas quintas-feiras a aula de Neurofisiologia Básica ia das 8:15 às 12:00h e das 14:00 às 17:00h. Nem posso descrever o estado em que chegava a casa após essa maratona neurofisiológica. Eu não conseguia nem falar muito menos ouvir qualquer palavra, caía na cama e dormia e, várias vezes, acabava sonhando com neurônios, sinapses, neurotransmissores e elementos químicos. A sensação era de estar vivendo dentro de uma aula sem fim. Comecei a ir dormir mais cedo na quarta feira, pois além de tudo a matéria se avolumava e o nível de complexidade aumentava. A sorte é que eu adorava os temas, pois várias foram às aulas em que mais da metade das palavras eram totalmente desconhecidas, em português, 
imagine em inglês!

No começo, quando lia os artigos em inglês, compreendia $20 \%$ no máximo, mas entendendo ou não depois participava das discussões. Enfim, no final do semestre já entendia $40 \%$ dos artigos em inglês. Desenvolvi uma estratégia que me ajudou muito, estivesse eu compreendendo ou não, me concentrava e mantinha a atenção do começo ao fim. No final da aula fazia um balanço do que havia conseguido absorver e do quanto havia percebido que desconhecia a existência.

Nunca fingi que sabia, sempre perguntei (aos alunos e professores) expondo as dúvidas com clareza. Porém, procurava estar sempre atenta para que minhas limitações não atrapalhassem a fluência das aulas.

Eu nem lembrava mais qual tinha sido a última prova que tinha feito na vida. Afinal, nas artes plásticas, a maioria das matérias é prática. Quando a data das provas estava se aproximando, alguns alunos me convidaram para ir estudar com eles, independente do grau de conhecimento específico de cada um. Desta forma, conseguimos estabelecer um ritmo que contemplou a todos e estudamos para as três provas.

Claro que eu precisava estudar também sozinha, senão nunca daria conta deste desafio. Para muitos, bastava tirar a nota necessária, mas para mim eu precisava muito mais, eu precisava aprender e aprender rápido, pois aquele era só o começo, além de aprender sobre o funcionamento do sistema nervoso eu precisava relacionar este novo conhecimento à prática e ao ensino da arte, e, infelizmente, não havia encontrado nada na literatura a esse respeito. Ou eu conseguia fazer essas associações ou iria para casa com a nota, mas sem o objetivo do meu trabalho.

E o tempo foi passando, eu fiz as provas e tirei $B$ em todas as disciplinas. Comemoramos todos: os alunos, os professores e eu. 
O mais difícil, no entanto, era conseguir conceber a forma como eles enfocavam suas questões. Parecia tão estranho! Nos enfoques em que eu não via interesse algum, para eles era de interesse máximo e vice-versa. A escala de valores, as prioridades e objetivos eram totalmente diversos. Para mim, em tudo havia cor, enquanto que, para eles, tudo era preto e branco, quando não escrito com lápis bem clarinho! Às vezes me perguntavam alguma coisa sobre o meu trabalho, mas nem sempre ouviam a resposta; outras vezes não entendiam a resposta. Fomos percebendo que, embora vivêssemos no mesmo mundo, habitávamos universos diferentes. A comunicação se estabelecia quando um prestava atenção no outro, sem imposição de conceitos. O fluir prazeroso de informações e vivências ocorria quando existia flexibilidade de pensamento. Porém, essa porta de comunicação se fechava œm o uso de posturas rígidas, que pretendiam impor a suposta superioridade de uma área em relação à outra. Cada área tinha algo a complementar e enriquecer a outra.

Já podia ir embora, tinha os créditos necessários e o conhecimento básico suficiente para alguém da área de artes plásticas, mas ponderei: se já havia chegado até aquele ponto, talvez fosse interessante seguir um pouco mais. Se ativasse um pouco mais as áreas cerebrais responsáveis pela memória e aprendizagem, como o córtex e o hipocampo, estimulando os processos bioquímicos responsáveis pelo registro dessas memórias, eu estaria construindo memórias de longa duração e o conhecimento adquirido com tanto esforço não seria esquecido após um breve período. Já estava relacionando o que havia aprendido sobre memória em minhas decisões cotidianas. Os conhecimentos adquiridos já não eram apenas elementos estranhos, ou objetos de estudo distantes de outra área do saber.

Matriculei-me na disciplina Neurotransmisão Serotoninérgica (BMA) e 
assisti como ouvinte as disciplinas: Comunicação celular no sistema nervoso (BMB), Introdução aos métodos de investigação e ensino da ciência (BMB).

Na matéria matriculada apresentei meu primeiro seminário aos pósgraduandos da área: Aprendizado, Memória e receptores serotononérgicos.(com o detalhe de ter produzido meu primeiro power point). Um super desafio! Tirei nota $A$, foi fantástico!

Fui voluntária de vários experimentos realizados no Laboratório de Psicofisiologia da Atenção e no Laboratório de Cronobiologia. Acompanhei aulas de neuroanatomia. Fotografei todo processo de Imunohistoquímica, um método histológico no qual visualizamos neurônios contendo proteínas receptoras e neurotransmissores, da serotonina $(5 \mathrm{HT})$ no encéfalo de ratos. Assisti defesas de doutorado e mestrado (sempre tem um amigo terminando). O Luiz Camêlo, doutorando em fisiologia, sempre perguntava: "Vera, quando é nossa qualificação?”, e, em seguida, comentava sorrindo: "Sim, pois a qualificação de Vera é a qualificação de todos nós". Acompanhei por dois anos as reuniões semanais do Laboratório de Psicofisiologia da Atenção, com o Prof. Luiz Eduardo Ribeiro do Valle.

Mas, eu sou uma Arte Educadora, que no momento estava estudando neurociências. Por mais que o ambiente dos laboratórios já não fosse hostil ou desconhecido; por mais que estivesse cercada de alunos e professores que aprendi a admirar ao entender os objetivos, os métodos, a análise dos resultados de suas pesquisas; por mais que fosse bem recebida e considerada por todos, ainda assim sentia muita falta de poder expressar da forma artística, e não apenas científica, as minhas opiniões, pesquisas, anotações e relatórios de atividades.

Foi então que vi uma possibilidade de suprir essa lacuna na disciplina 
Introdução aos métodos de investigação e ensino da ciência. A primeira parte desta aula era a apresentação de um seminário realizada por um aluno regular. Este devia, em exatamente 20 minutos, apresentar clara e objetivamente sua pesquisa de mestrado ou doutorado. Essa apresentação era avaliada por todo o grupo considerando as questões como forma e conteúdo, próprias de comunicações científicas. Após a aula, o apresentador recebia dos participantes da disciplina uma ficha escrita com as considerações, críticas e elogios referentes à sua apresentação. Ao invés de utilizar a linguagem escrita e seguir o roteiro de forma e conteúdo, das fichas de avaliação, resolvi utilizar a linguagem visual. Afinal, em arte, forma é conteúdo.

Portanto, entregava a minha avaliação uma semana mais tarde, pois precisava de tempo para desenhar, pintar e elaborar um suporte adequado para cada caso. Não sabia qual seria a reação dos colegas ao receberem esse tipo de avaliação, nada convencional, mesmo assim arrisquei. $O$ resultado foi muito interessante. Quando entregava a avaliação, explicava algum detalhe sobre a escolha das cores, o desenvolvimento da idéia, a coerência entre o tipo do suporte (sempre relacionado com o conteúdo do seminário), o ritmo da apresentação, o tom da fala, e a expressão do apresentador.

Ao superar a surpresa inicial, os comentários mais freqüentes com relação ao tipo de avaliação que adotei eram sempre: "Como a forma de uma avaliação é tão diferente da outra!"; "Como você tem tantas idéias?"; "Nossa, vou guardar de recordação junto com o meu trabalho." Acabei criando um tipo de avaliação que era sempre esperada com expectativa, recebida com um abraço espontâneo e um agradecimento verdadeiro. Precisei enviar as últimas avaliações pelo correio, pois as aulas terminaram e nenhum aluno queria deixar de receber sua 
avaliação colorida.

Para comemorar a despedida desta turma tão especial, pedi ao professor se poderia levar brigadeiro de colher no intervalo de nossa última aula. Então, inventei seis sabores de brigadeiro: amargo com castanhas, branco com cerejas, tradicional (para os mais conservadores), amargo com damasco, tradicional com café, branco com raspas de chocolate ao leite. Adorei a confraternização: colheres, pratinhos, copinhos, todos se servindo juntos, não teria o mesmo significado se os doces tivessem sido servidos em forminhas.

Eles comentaram que nunca tinham visto tantos sabores de brigadeiros, eu disse que também não conhecia antes de haver inventado. Então, perguntaram se eu havia escrito as receitas, e percebi que, como tenho facilidade e prazer em inventar coisas, geralmente se torna cansativo registrar o que já realizei. Não havia escrito as receitas! Como, então, alguém poderia reproduzi-las? Nos experimentos científicos sempre é necessário um protocolo metodológico de procedimentos, para que esses possam ser replicados e os resultados obtidos novamente analisados.

Reconheci que não havia registrado de maneira adequada experiências ricas em minha prática de ensino. Essas poderiam ser recursos valiosos, tanto para minhas futuras avaliações como para outros profissionais. O fato de confiar excessivamente em minha memória e em minha fluência para inventar algo novo em cada situação me levou a negligenciar este aspecto. Hoje, tendo estudado a psicofisiologia da memória, considero também como incentivo para efetuar registros adequadamente, a questão de que a memória modifica-se com agilidade, as conexões sinápticas dentro desse sistema podem ser reforçadas ou enfraquecidas. Além disso, podem ocorrer alterações estruturais e funcionais 
permanentes. Portanto, registrar já não me parece engessar uma experiência, como muitas vezes considerei.

Deste convívio surgiu o convite para participar do Curso de Verão, realizado durante o mês de Janeiro em 2005 e 2006, e ministrado pelos pósgraduandos do Departamento de Fisiologia /ICB. O curso fornece aos alunos da graduação, vindos de vários estados do Brasil, uma visão integrada da fisiologia entre seus diversos sistemas. Como o diferencial deste curso é propiciar ao aluno a vivência do conteúdo, preparei a palestra Ciência e Arte, considerando como a ciência e a arte se relacionam, fazendo parte do cotidiano de nossas considerações, decisões e ações.

Seguiram-se a criação e apresentação dos seminários: Arte e Sistema Atencional (Laboratório de Psicofisiologia da Atenção) e Percepção e Arte (Laboratório de Fisiologia Sensorial "Roberto Vieira").

Solicitação de uma seleção de quadros, dos grandes mestres da pintura ocidental, que pudessem ilustrar e levar o espectador a vivenciar o tema: "Assimetria interlateral no curso temporal da atenção voluntária". Essa seleção de imagens foi apresentada por Beatriz Castro-Barros, finalizando sua qualificação de doutorado.

A participação no simpósio Neurociência no século XXI, homenagem a Santiago Ramón y Cajal, prêmio Nobel de medicina e fisiologia em 1906, com uma série de seis painéis apresentando a vida e obra de Cajal, cientista que sempre integrou arte e ciência com maestria.

E com o esforço contínuo de relacionar o conhecimento das duas áreas, de tentar expor o conteúdo contido na ação artística para leigos-cientistas e do funcionamento do sistema nervoso para leigos-arte/educadores, acabei 
aprendendo coisas que não estão em nenhum livro. Muitas vezes me surpreendi aprendendo aspectos incríveis de arte ao estar estudando neurofisiologia, outras vezes fui capaz de fazer associações de temas antes inimagináveis.

Sou uma arte educadora que, ao estudar neurociências, teve a oportunidade de conviver e acompanhar algumas pesquisas realizadas nos laboratórios do ICB I, e lá pude descobrir a beleza da fisiologia, do organismo funcionando como um todo, de cada órgão exercendo sua função através de uma constante comunicação celular.

Hoje sou capaz de conceber a arte e o ensino e aprendizagem da arte também por uma abordagem biológica e inserida ao longo do desenvolvimento evolutivo do ser humano. E é com esse enfoque que desenvolvi essa dissertação. 


\section{ARTE E CIÊNCIA}

Arte e ciência, independente de atuarem em campos distintos, relacionam-se de diversas maneiras. Vários são os pontos convergentes e divergentes entre essas duas áreas. Por exemplo: tanto a arte como a ciência utiliza uma observação apurada para a realização de suas pesquisas, porém observam seus objetos de estudo a partir de pontos de vista distintos.

Os desafios de uma área podem, muitas vezes, parecer uma questão desinteressante para a outra, embora os resultados das pesquisas desenvolvidas por cada uma sejam de vital importância para o ser humano e para ambas. Pois, o conhecimento gerado nas duas áreas fornece o substrato necessário ao ser humano para que este possa fomentar novas investigações.

A ciência procura desvendar a constituição e os mecanismos de funcionamento de seu objeto de estudo; ocupa-se com a descrição e previsão de fatos. Atua medindo, calculando, inferindo, dissecando, formulando e testando hipóteses que poderão construir teorias, que, por sua vez, serão testadas experimentalmente, podendo ser replicadas, para então serem aceitas ou refutadas. A ciência procura saber, captar, apreender o máximo do fenômeno estudado com a mínima interferência pessoal. Ser impessoal é importante e necessário, considerado uma prioridade.

A arte busca a expressão, constrói seu conhecimento atuando de modo a compreender como se manifesta seu objeto de estudo e com quais qualidades e atributos se apresenta. É gerada a partir de uma intenção e utiliza-se de símbolos visuais, sonoros, cinéticos ou outros para produzir suas obras. A linguagem simbólica é estruturada numa composição organizando: a cor, a forma, o 
movimento, o som, a emoção, o ritmo e demais atributos que possam representar a intenção proposta. Seu propósito é interagir com o meio, relacionando-se, trocando informações, sensações e gerando novas maneiras de ver e apreender o seu objeto de estudo. A arte pode apropriar-se, interagir e, se necessário, interferir no fenômeno observado.

Mas, é interessante notar que entre tantas diferenças na maneira de conduzir suas pesquisas e apresentar seus resultados, existe um ponto central, comum tanto à arte como à ciência. Essas duas atividades são produtos da fluidez cognitiva, própria do ser humano; são fenômenos que vêm sendo produzidos pela espécie humana a pelo menos 43.000 anos.

Ao exercer atividades artísticas, o homem utiliza e gera conhecimentos que se transformam em produtos. Esses produtos irão fazer parte da formação da cultura.

Da mesma maneira, o homem, ao exercer atividades científicas, produz, com o resultado de suas pesquisas, outro tipo de conhecimento, que também se transforma em produto e também irá fazer parte da cultura.

Cultura é o modo como indivíduos ou comunidades respondem às suas próprias necessidades e desejos simbólicos. Engloba a língua, as idéias, as crenças, os costumes, os códigos, as ferramentas, as instituições, a arte, a religião, a ciência, enfim, toda a produção na esfera da atividade humana. Todo ser humano, sem exceção, ao nascer trás uma herança genética e recebe uma herança cultural. Com um patrimônio de 50 mil anos, nossa herança cultural é, no mínimo, bem vasta.

O antropólogo norte-americano Ralph Linton (1893-1959), exemplifica a difusão cultural em um texto admirável. Ele descreve o começo do dia do homem americano: 
O cidadão norte-americano desperta num leito construído segundo padrão originário do Oriente Próximo, mas modificado na Europa Setentrional, antes de ser transmitido à América. Sai de baixo de cobertas feitas de algodão, cuja planta se tornou doméstica na Índia; ou de linho ou lã de carneiro, um e outro domesticado no Oriente Próximo; ou de seda, cujo emprego foi descoberto na China. Todos esses materiais foram fiados e tecidos por processos inventados no Oriente Próximo. Ao levantar da cama, faz uso dos "mocassins" que foram inventados pelos índios das florestas do Leste dos Estados Unidos e entra no quarto de banho cujos aparelhos são uma mistura de invenções européias e norte-americanas, umas e outras recentes. Tira o pijama, que é vestuário inventado na Índia e lava-se com sabão que foi inventado pelos antigos gauleses, faz a barba que é um rito masoquístico que parece provir dos sumerianos ou do antigo Egito. Voltando ao quarto, o cidadão toma as roupas que estão sobre uma cadeira do tipo europeu meridional e veste-se. As peças de seu vestuário têm a forma de vestes de pele originais dos nômades das estepes asiáticas; seus sapatos são feitos de peles curtidas por um processo inventado no antigo Egito e cortados segundo um padrão proveniente das civilizações clássicas do Mediterrâneo; a tira de pano de cores vivas que amarra no pescoço é sobrevivência dos xales usados pelos croatas do século XVII. Antes de tomar o seu breakfast, ele olha a rua através da vidraça feita de vidro inventado no Egito; e, se estiver chovendo, calça galochas de borracha descoberta pelos índios da América Central e toma um guarda chuva inventado no sudoeste da Ásia. Seu chapéu é feito de feltro, material inventado nas estepes asiáticas. De caminho para o breakfast, pára para comprar um jornal, pagando-o com moedas, invenção da Líbia antiga. No restaurante, toda uma série de elementos bmados de empréstimo o espera. $O$ prato é feito de uma espécie de cerâmica inventada na China. A faca é de aço, liga feita pela primeira vez na Índia do Sul; o garfo é inventado na Itália Medieval; a colher vem de um original romano. Começa o breakfast com uma laranja vinda do Mediterrâneo Oriental, melão da Pérsia, ou talvez uma fatia de melancia africana. Toma café, planta abissínia, com nata e açúcar. A domesticação do gado bovino e a idéia de aproveitar o seu leite são originadas do Oriente Próximo, ao passo que o açúcar foi feito pela 
primeira vez na Índia. Depois das frutas e do café, vem waffles, os quais são bolinhos fabricados segundo uma técnica escandinava, empregando como matéria-prima o trigo, que se tornou planta doméstica na Ásia Menor. Rega-se com xarope de maple, inventado pelos índios das florestas do Leste dos Estados Unidos. Como prato adicional talvez coma um ovo de uma espécie de ave domesticada na Indochina ou delgadas fatias de carne de um animal domesticado na Ásia Oriental, salgada e defumada por um processo desenvolvido no Norte da Europa. Acabando de comer, nosso amigo se recosta para fumar, hábito implantado pelos índios americanos e que se consome uma planta originária do Brasil; fuma cachimbo, que procede dos índios da Virginia, ou cigarro, proveniente do México. Se for fumante valente, pode ser que fume mesmo um charuto, transmitido à América do Norte pelas Antilhas, por intermédio da Espanha. Enquanto fuma, lê notícias do dia, impressas em caracteres inventados pelos antigos semitas, em material inventado na China e por um processo inventado na Alemanha. Ao inteirar-se das narrativas dos problemas estrangeiros, se for bom cidadão conservador, agradecerá uma divindade hebraica, numa língua indoeuropéia, o fato de ser cem por cento americano (LINTON apud: LARAIA, 1988 p. 109-112).

Lendo esse texto e imaginando o percurso que o homem percorreu, desde a idade da pedra até os dias de hoje, torna-se claro o que significa o processo cultural para nossa civilização. Todas as ações desse "homem americano", que pode representar a todos nós, fazem uso de invenções que, ao serem concebidas, utilizaram ciência e arte.

Arte e ciência aparecem integradas nos produtos produzidos por uma cultura. E todos nós estamos envoltos numa cultura. Então, se arte e ciência são produzidas pelo homem, e fazem parte de nossa cultura, de que forma arte e ciência ocorrem em nossas ações cotidianas?

Ou será que arte é atividade exclusiva de artistas e ciência é produzida 
apenas por cientistas? De que modo você utiliza a arte e a ciência já disponíveis na cultura? E, como e quando você gera arte e ciência em sua vivência cotidiana?

Para responder essas questões, é melhor retornarmos ao ponto de partida. E, para o ser humano, o ponto de partida de suas ações vem de sua cabeça, da sua atividade neuronal encefálica. O início das invenções humanas normalmente está na capacidade de formular uma pergunta.

Por incrível que pareça tudo começa com uma pergunta. Cada vez que formulamos uma pergunta, todo nosso sistema nervoso passa a trabalhar com o potencial já armazenado, na geração de uma resposta, que para nos seja dotada de sentido. Uma resposta que nos satisfaça e que inevitavelmente nos conduzirá a outras perguntas. É o processo cognitivo, característico do ser humano. Através do acionamento dessa fluidez cognitiva é que estamos aptos a fazer ciência e também arte.

Assim como precisamos formular perguntas, também precisamos ouvilas para depois respondê-las. E, é no silêncio que podemos ouvir, com nitidez, as perguntas que povoam nossa mente. Muitas vezes, quando olhamos para o céu, no silêncio de uma noite escura e estrelada, quando sentindo a sensação de imensidão é que ouvimos nossas próprias perguntas com maior clareza.

E olhando para o céu estrelado, que perguntas o modo de pensar científico tem formulado ao longo do tempo? E quais são as perguntas que o modo de pensar artístico, tem feito ao longo do tempo?

Perguntas diferentes, baseadas no foco da atenção e na motivação com que foram formuladas, irão gerar respostas diferentes e usarão meios distintos para concretizar suas respostas. Então, a partir das respostas obtidas, o que foi realizado? Quais foram as obras da ciência e quais foram as obras da arte? 
Quando o homem, ao olhar para o céu estrelado, se questionou sobre distâncias, órbitas, formação e constituição das estrelas, possibilidades de se locomover no espaço, do que é formado o espaço, constituição dos elementos físicos e químicos da atmosfera, o homem construiu aviões, foguetes, mapeou o céu, observou a órbita dos planetas, coletou dados, construiu aparelhos para darem suporte tecnológico para suas pesquisas, enfim, explorou o espaço e levou a si mesmo a pisar na lua e sondas espaciais a andar na superfície de Marte.

E quando o homem olhou para o mesmo céu estrelado com outro foco atencional? Que questões surgiram ao observar um verdadeiro espetáculo de brilhos e formas? Como expressar as diversas sensações percebidas? Que formas podem ser transpostas para os objetos que nos cercam? Que estórias se pode inventar? Que imagens poderiam transmitir a grandiosidade do universo? Como seriam os habitantes de mundos distantes? Quais enigmas mantêm esse imenso quadro celeste em constante movimento?

E a partir deste tipo de questionamento o homem criou histórias, desenhos, esculturas, a ficção científica, poemas e poesias; obras capazes de trabalhar com o desconhecido e colocá-lo ao alcance do entendimento humano; ao alcance da imaginação, na qual podem ser manipulados, concebidos e transformados. O homem trouxe a beleza e as sensações percebidas na galáxia para conviver no cotidiano, formando peças utilitárias, criando artefatos, brinquedos e tantos outros objetos que nos cercam.

E continuando a olhar para o céu, mas agora mais de pertinho, admirando um céu azul sem nuvens com um bando de pássaros voando, talvez imigrando para algum lugar distante, o que o homem teria observado? Como ele percebeu a harmonia das aves que se movem em uma determinada direção? Quais 
formas Ihe chamaram a atenção? Que gama de cores ele notou? Que tipo de movimento, que ritmos, noções de distâncias, percepção do espaço e do tempo ele teve? Que perguntas teria formulado?

O homem, observando e ouvindo o canto dos pássaros, criou instrumentos musicais e compôs melodias. Ao sentir a leveza e a harmonia do vôo, e querer expressá-las com seu corpo, criou a dança, os passos e saltos de ballet. Em forma de versos e poemas conversou longamente com as aves. Na pintura, um festival de cores coloriu plumas e penas. E, na escultura, nos brinquedos e nos utilitários, os pássaros foram desenhados e moldados das mais variadas formas. Assim, suas reproduções viajaram por todo o mundo, perfazendo maior quilometragem que a dos pássaros verdadeiros.

E observando o mesmo céu azul em que pássaros voam em bando, o homem fez outras tantas perguntas. Por que o céu azul? Como é possível se sustentar no ar? Como as aves sabem em que direção voar? De que tipo de matéria são formadas as penas das aves?

E observando as características das aves, formulou os princípios da aerodinâmica, desenvolveu a biologia estudando o comportamento dos animais em seu habitat; a fisiologia, a anatomia, a física, a mecânica entre tantas outras especialidades. 


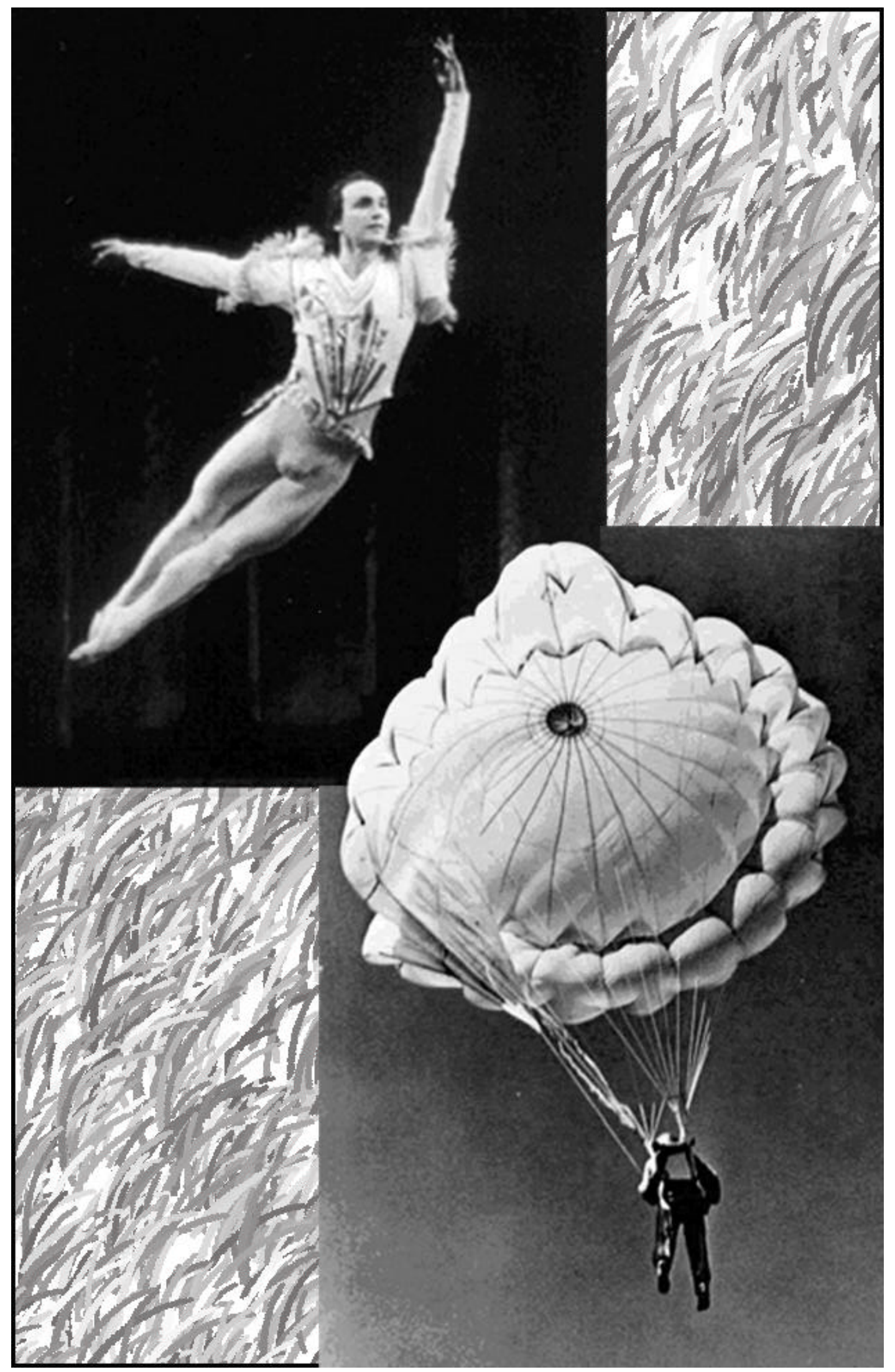

Ao observar as duas fotografias acima, o salto de ballet e o salto de pára-quedas, à primeira vista pode ser que relacionemos o ballet com a arte e o 
pára-quedas com a ciência. Porém, ao analisarmos um pouco mais, logo perceberemos que no salto de ballet existe muito conhecimento sobre anatomia (uma ciência), caso contrário o bailarino lesionaria seus tendões e certamente não poderia dar mais nenhum salto.

Do mesmo modo, pode haver uma ação artística ao se executar um salto de pára-quedas. Assim, separar arte e ciência em uma atividade não é uma tarefa simples. E separar a ciência e a arte em objeto, sem descaracterizar completamente esse mesmo objeto é praticamente impossível. Por exemplo, na foto abaixo vemos uma BMW Z4; se retirarmos "toda"de ciência ou "toda"a arte utilizada para fabricar esse modelo, a BMW Z4 continuaria sendo uma BMW Z4? Certamente, não!

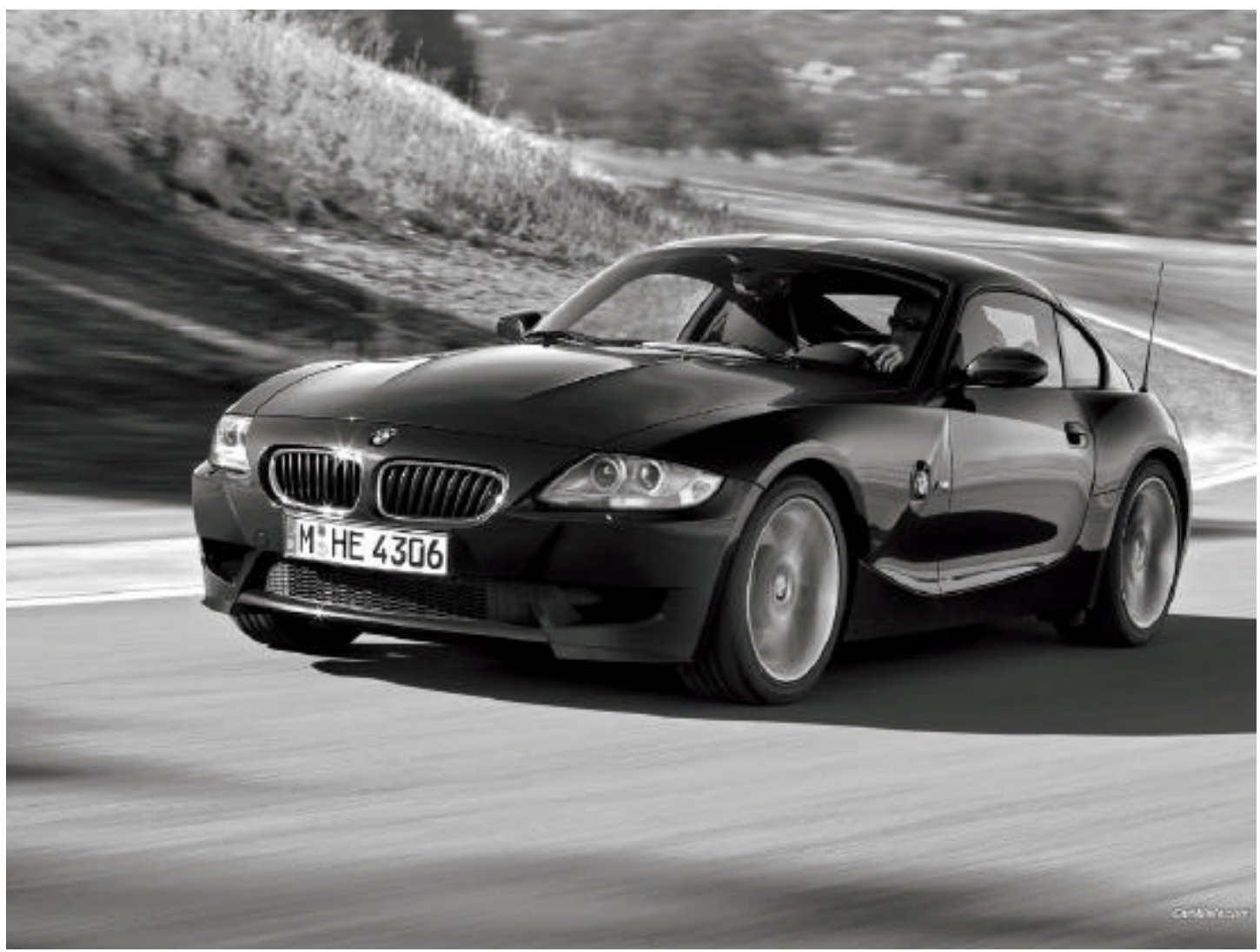

Embora arte e ciência se apresentem de modo integrado, mesclandose nos produtos culturais inventados pelo homem, a criação de novos produtos da 
arte ou da ciência se realiza a partir de estratégias distintas. Os artistas criam suas produções, geralmente nos ateliês, a partir da concepção do significado da arte. E, os cientistas realizam suas pesquisas e descobertas a partir de métodos científicos realizados habitualmente em laboratórios.

Em geral é um trabalho de equipe, realizado por muitas mãos. Contudo, vale lembrar que o manusear das mãos é uma atividade coordenada pelo encéfalo. Assim sendo, como funcionaria um encéfalo capaz de realizar tarefas tanto artísticas quanto científicas? Será que o homem comum é capaz de fazer ciência e arte ao mesmo tempo? Ou será que essa é uma possibilidade apenas reservada às mentes geniais?

Robert e Michèle Root-Bernstein vêm estudando o tema criatividade há mais de uma década. Robert é professor de fisiologia na Michigan State University e Michèle é historiadora. Suas pesquisas buscam responder as seguintes questões: Será que temos condições de entender o que é a imaginação criativa? $E$, se entendermos, será possível exercitá-la, treiná-la e educá-la?

Estes pesquisadores têm se dedicado a recolher, estudar e interpretar as histórias contadas por pensadores, artistas, cientistas e inventores eminentes. Num de seus estudos, analisaram cientistas de grande sucesso, entre os quais muitos laureados com o Prêmio Nobel, e identificaram uma enorme freqüência de vocações artísticas entre eles. Em sua publicação de $1997^{1}$, Root-Bernstein enumera 73 cientistas renomados, encontrando entre eles 25 músicos e compositores; 29 pintores, escultores, gravadores, desenhistas; 19 poetas, novelistas e teatrólogos. A lista a seguir destaca alguns dos nomes citados nesse trabalho:

\footnotetext{
${ }^{1}$ Root-Bernstein, Robert. Discovering. Replica Books; 1st Replic edition, 1997.
} 
Poetas, novelistas, teatrólogos ${ }^{2}$ :

- Hill, Archibald V. (1886-1977)

- Richet, Charles* (1850-1935)

- Ross, Sir Ronald* (1857-1932)

- Sherrington, Charles* (1857-1952)

- Bernard, Claude (1813- 1878)

- Jenner, Edward (1749-1823)

Músicos e compositores ${ }^{3}$

- Békésy, Georg von* (1889-1972)

- Monod, Jaques* (1910-1976)

- Ross, Sir Ronald ${ }^{*}$ (1857-1932)

- Theorell, Axel Hugo Theodor* (1903-1982)

- Helmholtz, Hermann von (1863-1931)

- Holmes, Oliver Wendell (1809-1894)

- Jenner, Edward (1749-1823)

- Laennec, R-T-H (1781-1826)

- Schweitzer, Albert (1875-1965)

Pintores, escultores, gravadores, desenhistas ${ }^{4}$

- Adrian, Edgar Lord* (1889-1977)

- Banting, Sir Frederick* (1891-1941)

\footnotetext{
${ }^{2}$ Todos os nomes marcados com * são ganhadores do Prêmio Nobel em medicina e fisiologia.

${ }^{3}$ Todos os nomes marcados com * são ganhadores do Prêmio Nobel em medicina e fisiologia.

${ }^{4}$ Todos os nomes marcados com * são ganhadores do Prêmio Nobel em medicina e fisiologia.
} 
- Ramon-y-Cajal, Santiago* (1852-1934)

- Pasteur, Louis (1822-1890)

- Jung, Carl Gustave (1875-1961)

- Charcot, Jean Martin (1825-1893)

- Loewi, Otto (1873-1961)

- Fleming, Sir Alexander* (1881-1955)

- Florey, Sir Howard* (1898-1968)

- $\mathrm{G}$, Edwin S.* (1868-1946)

- Guillemin, Roger* (1924)

- Luria, Salvadore (1912-1991)

- Holley, Robert* (1922- 1993)

Em seu livro, Centelhas de Gênios, os autores demonstram a necessidade da articulação entre arte e ciência para o fomento da criatividade e capacidade de inovação. Já no prefácio apontam para o fato de que "o pensamento criativo ocorre anteriormente à fala, antes que entrem em cena a lógica ou a lingüística, manifestando-se em emoções, intuições, imagens e sensações corporais", comuns aos processos vivenciados por artistas e cientistas. As ferramentas mentais utilizadas nestes processos cognitivos permitem conexões surpreendentes entre ciências, arte, humanidades e tecnologias, pois, utilizando a imaginação criativa, todos pensam da mesma maneira. Entre essas ferramentas essenciais à educação em todos os níveis, estão: potencializar a imaginação, observar, evocar imagens, abstrair, reconhecer padrões, formar padrões, estabelecer analogias, pensar com o corpo, ter empatia, pensar de modo dimensional, criar modelos, brincar, transformar, sintetizar. 
$\mathrm{Na}$ história de nossa civilização, o homem que integrou, de modo magistral, arte e ciência no seu viver, foi Leonardo da Vinci. Nas duas áreas ele produziu obras de valor e relevância, que são consideradas como patrimônio da humanidade. Através de um estudo minucioso dessas obras, temos a oportunidade de imaginar como funcionava a mente desse mestre, como ele articulava e ordenava o conhecimento que adquiriu observando a natureza.

Já se passaram mais de quinhentos anos desde a morte de Leonardo da Vinci. Ele viveu bem antes de Galileu e Newton. Entrava na penúltima década de sua vida quando Cabral descobriu o Brasil.

Para apreciar melhor e ter parâmetros para avaliar a vitalidade das formas expressivas e do conteúdo significativo de suas obras é necessário ter esse tempo em mente.

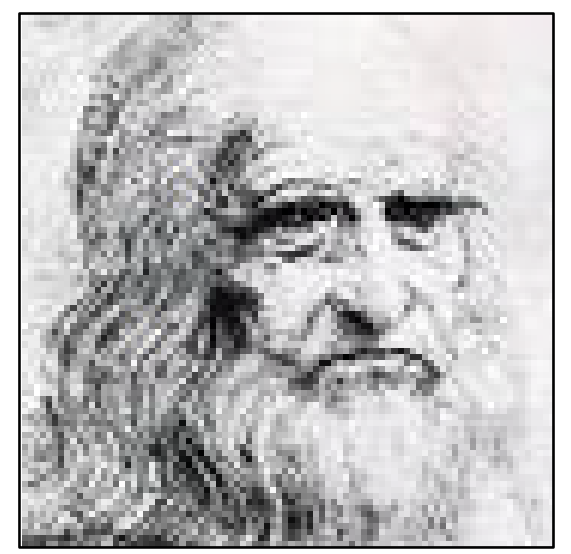

Leonardo (1452-1519) nasceu em Vinci, uma pequena cidade próxima a Florença, na Itália do século XV, época da Alta Renascença. Florença havia se tornado um centro cultural dos mais importantes do mundo ocidental, onde a economia, a cultura, a ciência e as artes prosperavam.

Leonardo passou a infância imersa na natureza, "costumava passar longas horas nos campos e bosques perto de sua casa, observando e desenhando plantas, pássaros, morcegos, lagartas, cachorros, cavalos, até mesmo inventado figuras de animais imaginários, como brincadeira para assustar as pessoas" (FAYGA, 2003, p. 7).

Desde cedo demonstrou interesse em buscar respostas e compreender os mecanismos intrínsecos de como os organismos funcionam. O desenho foi um 
dos instrumentos que utilizou para desvendar os enigmas do universo. Todo o conhecimento que adquiriu e a forma como este foi construído transparece em suas obras.

Os interesses universais deste mestre se encontram em diversas áreas, nas quais o artista desempenhou seus papéis de anatomista, botânico, engenheiro civil e militar, arquiteto, urbanista, hidrólogo, cartógrafo, inventor e pintor.

Vários trabalhos de Leonardo não foram terminados; inúmeras de suas invenções não chegaram a ser construídas na época. O grande legado de Da Vinci vem através das anotações registradas em seus cadernos. Ele preencheu cerca de 5.000 páginas com esboços meticulosos, acompanhados de anotações detalhadas escritas de forma invertida (da direta para a esquerda) que após sua morte levaram cerca de 250 anos para virem a público.

Depois de grandes campanhas pela publicação e tradução, a partir de 1880, os manuscritos de Leonardo da Vinci tornaram-se cada vez mais conhecidos dos estudiosos e do público; hoje vários deles podem ser consultados através da internet. Eles são absolutamente excepcionais. O acesso aos originais desses cadernos, mesmo que on-line, faz toda a diferença no desenvolvimento de uma pesquisa. A pesquisa realizada a partir da consulta da fonte primária é fundamental, principalmente quando se trata da obra de Leonardo Da Vinci, que tem sido explorada e deturpada por cinco séculos.

Ernest Gombrich, professor e historiador da arte, ao referir-se aos cadernos de Da Vinci escreveu:

Quanto mais se lêem esses cadernos, menos se pode entender como um ser humano foi capaz de se destacar de forma tão excelsa num sem-número de diferentes campos de pesquisa e de dar 
importantes contribuições para quase todos eles. Talvez uma das razões resida no fato de Leonardo ser um artista florentino e não um erudito de formação acadêmica. Pensava que a função do artista era explorar o mundo visível, tal como seus predecessores tinham feito, só que mais completamente e com maior intensidade e precisão (GOMBRICH, 1888, p. 221).

A única forma válida de conhecimento para Da Vinci era olhar para as coisas reais e os fenômenos, os quais olhou com intensidade e os representou com a maior originalidade. Sua concepção era que o ato de ver abrangia os dois sentidos do verbo, que são olhar para e compreender. O objetivo de Leonardo, de ver no sentido de compreender, só podia ser realizado pela análise da própria visão. O olho era, para ele, o instrumento maior dos cinco sentidos - uma concepção tradicional muito influenciada por Platão e Aristóteles - audição, tato, paladar e olfato ficavam abaixo da visão. O olho era o mestre analítico de todas as pesquisas visuais. Para Da Vinci, o ato de olhar e desenhar era uma maneira de compreender as leis da natureza, e é com base nessa compreensão que o artista alimentava sua fantasia (imaginação) para poder inventar e criar suas obras.

Os desenhos de Leonardo Da Vinci ultrapassavam as descrições de um tema; eram também um meio de investigar, compreender e predizer o mundo natural à sua volta. Sua ousadia e seus interesses variados lhe permitiram fazer observações e descobertas em várias áreas científicas, da anatomia à geologia. Nas palavras de Da Vinci, "O desenho é de tamanha excelência que não apenas demonstra as obras da natureza, mas outras infinitas, além daquelas criadas pela natureza" (ZÖLLNER, 2005).

Leonardo explorou os segredos do corpo humano, dissecando mais de 30 cadáveres. Tarefa bastante audaciosa para a época, considerando as 
perseguições do clero e as precárias condições de iluminação, ventilação e técnicas de preservação dos cadáveres.

Seus primeiros desenhos anatômicos datam de 1497-1499 e refletem grande conhecimento da anatomia da superfície do corpo humano, porém pouca familiaridade com os órgãos internos; nessa época Da Vinci começa a planejar um livro de anatomia com colaboração de Marcantonio Della Torre, um professor da Universidade de Pavia, porém este projeto não chegou a se realizar. Leonardo Da Vinci seguiu dissecando e desenhando, não só cadáveres humanos como também animais, especialmente cavalos. Foi um dos primeiros a aprofundar os mistérios do crescimento da criança no ventre materno.

Os desenhos anatômicos de seus últimos anos em Milão revelam que a prática da observação minuciosa aliada a sua destreza pictórica, sua capacidade de visualizar a forma e deduzir a função, culminaram no desenvolvimento de uma técnica de ilustração anatômica até então inexistente.

Nas palavras de William Hunter (1718-1783), professor de anatomia da Royal Academy of Arts em Londres de 1769 até 1772:

Eu esperava ver apenas vulgares desenhos de anatomia nos quais um pintor pode encontrar alguma utilidade para o exercício do seu mister. Mas para minha grande surpresa, constatei que Leonardo adquirira um conhecimento muito vasto, e muito profundo. Quando considero os esforços que ele dedicou a cada parte do corpo, a superioridade do seu gênio universal, os seus profundos conhecimentos da mecânica e da hidráulica e o cuidado que põe em examinar todas as coisas que desenha, não tenho a menor dúvida de que Leonardo foi, no seu tempo, o maior anatomista do mundo (HUNTER aput: ZÖLLNER, 2005, p. 90). 
Nada existia na natureza que não despertasse a sua curiosidade e não desafiasse o seu engenho. Investigou as leis das ondas e correntes; passou anos analisando o vôo de insetos e pássaros, o que iria ajudá-lo a inventar uma máquina voadora. Esse invento era uma espécie de asa-delta onde vemos um homem amarrado a um complicado mecanismo de quatro asas, cada um com doze metros de comprimento. Leonardo tinha convicção de que um dia esse invento se tornaria uma realidade.

E esse não foi o único invento de Da Vinci, existem muitos outros, por exemplo: o helicóptero, a bicicleta, o sistema de respiração para mergulho, o martelo pilão, as almofadas de bolas, a escada mecânica, o macaco, o robô, os blindados e outras tantas máquinas de guerra. Várias dessas invenções não foram construídas e testadas na época, porém hoje praticamente todas já foram estudadas e construídas $^{5}$, seguindo criteriosamente as anotações dos cadernos de Da Vinci, e utilizando os materiais sugeridos disponíveis na época em que foram concebidas. 0 incrível é que essas invenções, além de geniais, funcionam!

As formas de pedras e nuvens, o efeito da atmosfera sobre a cor de objetos distantes, as leis que governam o crescimento de árvores e plantas, a harmonia de sons, tudo isso era objeto de sua incessante pesquisa e seria a base tanto de sua arte como de sua ciência.

Leonardo jamais aceitava o que lia sem verificar com seus próprios olhos. Sempre que deparava com um problema, tentava realizar um experimento que o resolvesse.

Seu modo de conceber a visão como análise e a representação como infinitamente variada foi um legado de sua formação artística florentina. A arte

\footnotetext{
${ }^{5}$ O Museu de Ciência e Tecnologia de Milão possui uma exposição permanente das réplicas das invenções de Leonardo da Vinci. <http://www.museoscienza.org/Default.htm>.
} 
florentina do século XV contava com a invenção da perspectiva, divulgada em um livreto fundamental, sobre a pintura, do escritor e arquiteto Leona Battista Alberti, escrito em 1435.

A perspectiva linear aliava procedimentos racionais com a concepção imaginária de uma nova cena, e colocava a invenzione em união íntima com a scienza. A invenzione era definida como a criação de algo novo, real ou plausível (numa paráfrase do grande orador Cícero, da antiga Roma), enquanto a scienza era um corpo de conhecimentos baseados em princípios racionais e comprováveis. Num nível mais profundo, era uma aliança entre a fantasia (imaginação) e o intelleto (o poder racional da mente). Em tudo isso é importante ter em mente que os termos empregados por Da Vinci em língua italiana têm, com freqüência, diferentes conotações hoje, e justamente por isso estão em negrito (KEMP, 2005).

Leonardo utilizou a perspectiva de um modo único e genial na composição de seu mural $A$ Última Ceia. Entre as obras de Leonardo, A Última Ceia tornou-se uma das mais famosas imagens da arte ocidental. A Última Ceia é um mural de grandes dimensões $(9,10 \mathrm{~m} \times 4,20 \mathrm{~m})$, foi encomendada em 1495 pelo duque Ludovico il Mouro para o refeitório do Convento de Santa Maria delle Grazie, em Milão. O tamanho monumental e o tema bastante complexo - o momento em que os discípulos ouvem, consternados, Cristo anunciar que será traído por um deles - exigiram do artista a integral dedicação e intensa concentração, o máximo empenho intelectual e emocional, enfim, sua experiência e total capacidade artística.

A pintura de um tema bíblico como a Última Ceia nasceu obviamente de sua fantasia ${ }^{6}$ (imaginação), Ao considerar, o olho como sendo sempre um aliado do intelecto, Da Vinci não suprime ou diminui a importância da fantasia em suas

\footnotetext{
${ }^{6}$ Leonardo Da Vinci utiliza o palavra fantasia com o mesmo sentido que atribuímos, nos dias de hoje, à palavra imaginação.
} 
criações. Assim sendo, também é verdade que o retratos que pintou não são simples transcrições diretas daquilo que via.

Para poder pintar com o maior cuidado as delicadas nuances e transições do colorido, tendo a possibilidade de fazer eventuais correções e retocar certos trechos da imagem, Leonardo inventou uma nova técnica. Diferente do tradicional afresco (que exige rapidez e definição imediata ao ser aplicar, em uma única camada, o reboco ainda úmido já misturado aos diversos pigmentos) a nova técnica incluía uma segunda camada de gesso, como suporte de uma liga de têmpera (com óleo) para receber o colorido mais fluído e delicado das pinceladas.

Talvez só possamos apreciar totalmente a extraordinária proeza de Leonardo nessa composição se voltarmos a refletir como os artistas dessa geração tinham batalhado para combinar as exigências do realismo com as do padrão convencional [...] A composição parece ter aquele equilíbrio sem esforço e aquela harmonia das pinturas góticas [...] subitamente sentimo-nos diante de um fragmento de realidade tão convincente e tão impressionante [...] devemos, além de toda técnica, admirar a profunda intuição de Leonardo sobre a natureza íntima do comportamento e das reações dos homens, e do poder de imaginação que o capacitou a colocar a cena ante os nossos olhos (GOMBRICH, 1988, p. 226).

Georgio Vasari ${ }^{7}$ relatou o processo de trabalho utilizado por Leonardo da Vinci neste mural. Ele subia no andaime e aí ficava de pé, dias inteiros de braços cruzados, apenas observando o que já havia feito, antes de dar outra pincelada. Depois saía com seu bloco de anotações fazendo esboços de fisionomias e posições diversas do corpo humano, reunindo material para compor um desenho

\footnotetext{
7 Giorgio Vasari (Arezzo, 1511 - Florença, 1574) foi um pintor e arquiteto italiano conhecido principalmente por suas biografias de artistas italianos.
} 
que refletisse a personalidade de cada discípulo. As pessoas representadas nesta ceia são retratos de várias pessoas da corte e de milaneses da época em tamanho natural. Ao retornar ao Convento de Santa Maria delle Grazie muitas vezes trabalhava freneticamente, durante dias, e novamente passava a observar e analisar o que já havia pintado. Foi o resultado desse pensamento que ele nos legou e, mesmo em seu estado deteriorado, A Última Ceia continua sendo uma das grandes obras produzidas pelo homem, que retrata o próprio gênero humano ZÖLLNER, 2005).

O mural levou três anos para ser concluído. Nos anos imediatos à sua conclusão tornourse uma sensação não só entre os artistas, que o copiaram ampla e imediatamente em uma variedade de escalas e técnicas, como também os visitantes importantes e curiosos que foram ver a obra em Milão, incluindo aí o rei da França e sua corte. O comentário geral de todos era de que $A$ Última Ceia parecia mais uma obra da natureza que da arte.

Infelizmente, duas décadas após a conclusão do mural, a camada colorida começou a deteriorar-se. Os problemas apontados foram a umidade excessiva do local, a química da própria mistura da têmpera e deficiências no prépreparo da parede antes de receber a pintura. $O$ fato é que, restaurada e repintada por vários séculos, nem sempre de maneira apropriada, o que podemos ver hoje é apenas a infra-estrutura deste incrível mural, mesmo assim, até os dias de hoje continua sendo uma das imagens mais reproduzidas no mundo inteiro.

Martin Kemp, historiador da arte e especialista no estudo da obra de Leonardo Da Vinci há 30 anos, argumenta que,

Cada ato de olhar e desenhar era, para Leonardo, um ato de análise, e é com base nessas análises que o criador humano pode refazer o mundo. Assim, a máquina voadora e a Mona Lisa refazem, 
comparativamente, o mundo natural segundo os próprios termos desse mundo, em perfeita obediência às causas e aos efeitos naturais. Uma é um "pássaro" artificial; a outra uma reprodução da experiência visual da presença física da pessoa (KEMP, 2005, p. 49).

Outra de sua obra, a Mona Lisa ${ }^{8}$, é o retrato mais famoso do mundo. Como Gombrich bem escreveu:

Uma fama tão grande quanto a da Mona Lisa não é uma bênção completa para uma obra de arte. Ficamos tão habituados a vê-la em postais e até publicidade, que se torna difícil olhá-la com os olhos isentos como a pintura feita por um homem real, retratando uma mulher real, de carne e osso. Mas vale a pena esquecer o que sabemos, ou acreditamos saber, sobre o quadro, e examiná-lo como se fôssemos as primeiras pessoas a fixar os olhos nele. O que logo nos impressiona é o grau surpreendente com que Lisa parece viva. Ela parece realmente olhar para nós e possuir um espírito próprio. Como um ser vivo, parece mudar ante os olhos e estar um pouco diferente toda vez que voltamos a olhá-la. Até mesmo em fotografias do quadro sentimos esse estranho efeito, mas diante do original, no Museu do Louvre, em Paris, a sensação é quase sobrenatural. Por vezes, ela parece zombar de nós; outras vezes, temos a impressão de surpreender uma sombra de tristeza em seu próprio sorriso. Tudo isso tem um ar misterioso, e assim é; muito freqüentemente, é esse efeito de uma grande obra de arte. Não obstante, Leonardo certamente sabia como obteve esse efeito, e por que meios. $\mathrm{O}$ grande observador da natureza sabia mais sobre a forma como usamos os olhos do que qualquer pessoa do seu tempo ou antes dele (GOMBRICH, 1988, p. 228).

Essa era a tarefa essencial de Leonardo, ver e observar a natureza

\footnotetext{
${ }^{8}$ Mona Lisa (Óleo sobre madeira, 1503-1506, $77 \mathrm{~cm} \times 53 \mathrm{~cm}$ ). O quadro está exposto no Museu do Louvre, em Paris. Os livros de história da arte concordam em dizer que a dama florentina pintada no quadro era Lisa Gherardini, esposa de um influente comerciante de Florença, Francesco di Bartolomeo di Zanoli de Giocondo. A obra é chamada por vários nomes: como Mona Lisa, o mais conhecido, e La Gioconda.
} 
com os olhos sempre novos, descobrir e comprazer-se na criação de novas harmonias de cor e luz.

Leonardo considerava que o pintor deve deixar ao espectador algo para adivinhar. Se os contornos não são desenhados com maior firmeza de traço, se a forma é deixada um pouco indefinida, como desaparecendo numa sombra, a impressão de secura e rigidez será evitada. Essa é a famosa invenção de Da Vinci, chamada Sfumato - um lineamento esbatido e cores esfumaçadas que permitem a uma forma fundir-se com outra e deixar sempre algo para alimentar a imaginação.

Fayga Ostrower ${ }^{9}$, analisando a estrutura formal dessa composição, demonstra que esta é baseada em uma proporção chamada "seção áurea". Tanto a silhueta triangular da figura como suas principais subdivisões que definem a altura e a movimentação da cabeça, do corpo, das diagonais dos braços cruzados e das mãos podem ser identificadas dentro do padrão da seção áurea (OSTROWER, 2004).

E é com técnica e poesia, com ciência e arte, que Da Vinci consegue mostrar algo que vai além da própria pessoa retratada. À primeira vista, não se percebe a complexidade dos múltiplos relacionamentos formais que dão sustentação aos inúmeros significados que coexistem no conteúdo expressivo da imagem. Uma das características da obra de Leonardo é a existência de uma poderosa síntese, que integra todos os elementos e transmite uma extraordinária harmonia. Fayga expressa suas impressões com as seguintes palavras:

O sorriso da Mona Lisa! Enigmático, fugidio, suave, talvez melancólico, mas sempre um sorriso. Leonardo captou-o como se fosse um sopro na eternidade, existindo por um instante e desde sempre. Ainda seu olhar! Vindo do fundo da alma, parece penetrar

\footnotetext{
${ }^{9}$ Fayga Ostrower (Polônia, 1920 - Brasil 2001) é uma renomada artista plástica brasileira, atuou como gravadora, pintora, desenhista, ilustradora, teórica da arte e professora.
} 
em nossa alma também, fala-nos de sentimentos para os quais não existem palavras e levando-nos às infinitas distâncias do Universo. $\mathrm{E}$ não é só a Mona Lisa que sorri, é a paisagem toda. Pois tudo está imerso na misteriosa luminosidade, onde o claro e o escuro se interpenetram de tal modo - o escuro passando para dentro do claro e o claro para dentro do escuro - que se torna impossível dizer onde termina a luz e onde começam as sombras (OSTROWER, 2003, p. 26).

Embora a Mona Lisa fosse um retrato encomendado, o quadro nunca foi entregue. Leonardo o guardou para si, levando-o consigo por todos os lugares onde viveu e trabalhou. Aos 64 anos, Leonardo aceitou o convite do jovem rei da França, Francisco I, para morar em Cloux, para onde levou o quadro da Mona Lisa e guardou até a morte. Após sua morte, o quadro permaneceu na corte francesa e hoje está exposto no Museu do Louvre, em Paris.

Leonardo foi um grande artista entre outros grandes artistas de sua época. Não faltaram grandes mestres nem obras-primas durante a renascença. Desde os artistas dos Países Baixos, que demonstravam aguda observação da natureza e suprema paciência para os pormenores e exatidão de detalhes, até Andréa Mantegna (1431-1506), artista italiano que utilizou da perspectiva para gerar representações imponentes e grandiosas, acentuadas por efeitos dramáticos e teatrais. Além desses, estavam em plena atividade grandes mestres renascentistas como, Michelangelo, Rafael, Ticiano e Boticelli. A marca desses grandes mestres é que eles sabem detalhar o que for preciso, ou então generalizar, sem jamais perder a justa medida e o sentido conjunto da composição. Portanto, ser grande entre os grandes não é uma tarefa fácil.

Não obstante, algo a mais se manifestava na personalidade de Leonardo da Vinci. Sua ousadia, seus interesses variados e seu sistema de 
pesquisa the permitiram fazer observações e descobertas relevantes não só no campo das artes, mas também em todas as áreas em que atuou.

Leonardo da Vinci era um artista-cientista, uma pessoa de uma visão realista fantástica, que estaria em destaque em qualquer época que vivesse. Leonardo representou um ideal que não se pode mais alcançar: o "homem da Renascença", que era capaz de dominar simultaneamente muitas formas do conhecimento. Leonardo foi um notável anatomista, botânico, engenheiro civil e militar, arquiteto, urbanista, hidrólogo, cartógrafo, inventor e pintor. Com a avalanche do conhecimento, que começou no lluminismo e na Era Industrial, e que continua com uma velocidade espantosa em nossa atual Era da Informação Globalizada, é improvável que um único homem, seja ele artista e/ou cientista, possa abranger algo que seja maior que o seu campo de especialidade.

Mas, seja qual for a especialidade à qual nos dediquemos, com certeza nosso trabalho terá maior alcance caso seja desenvolvido com ciência e arte.

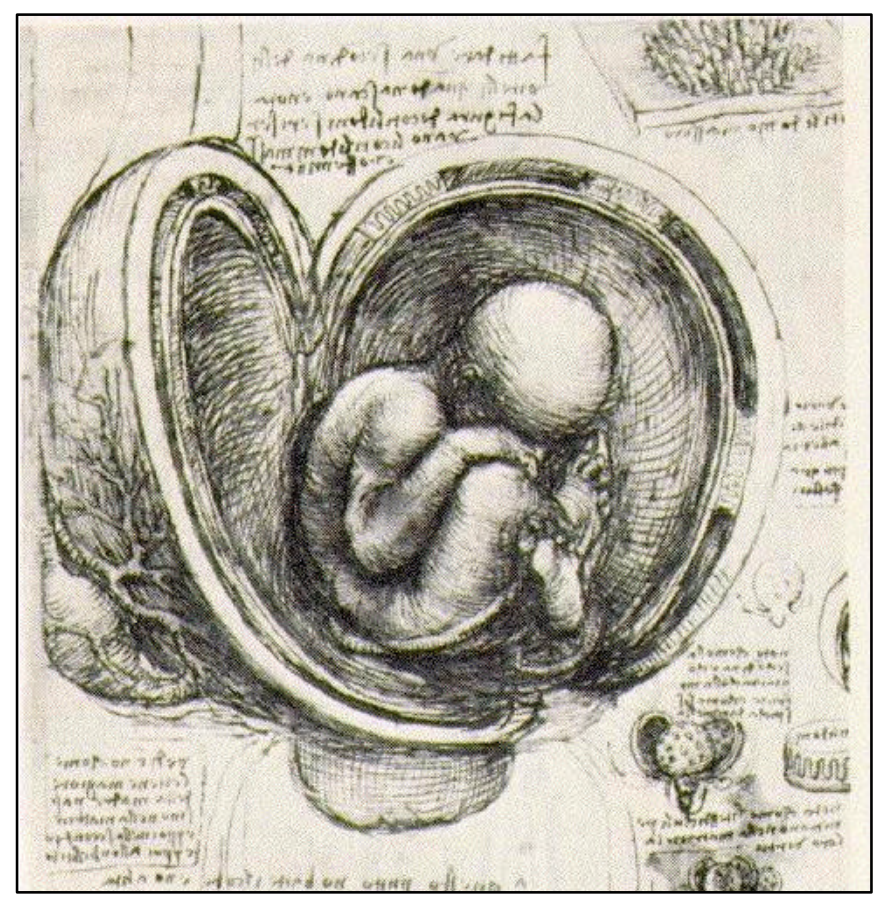



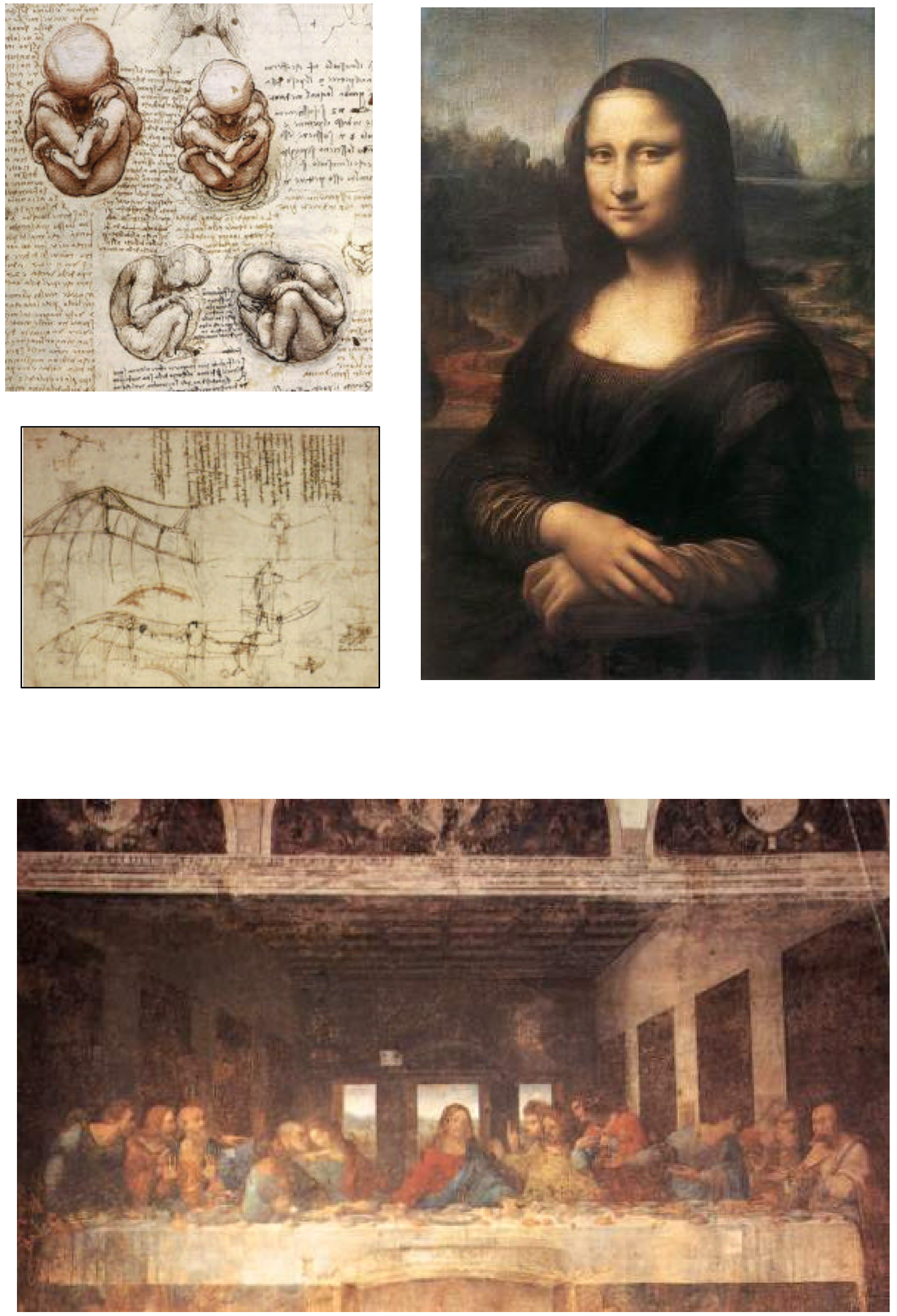


\section{CIÊNCIA}

\subsection{Imaginando o funcionamento do sistema nervoso}

Aprender, ensinar, correr, pintar, desenhar, dançar, cantar... Cada uma destas ações é planejada, executada e posteriormente analisada com o funcionamento do nosso sistema nervoso. Assim sendo, é o sistema nervoso que oferece o suporte para que possamos praticar uma ação artística.

É comum observar o encantamento das pessoas que estudam o sistema nervoso em ação. Os gregos diziam que se maravilhar é o primeiro passo no caminho da sabedoria, e que quando deixamos de nos maravilhar, estamos em perigo de deixar de saber. Torna-se um espetáculo maravilhoso visualizar as inúmeras possibilidades de conexões neurais realizadas no encéfalo para que um simples movimento possa ser efetuado.

Não são apenas as estrelas no universo que fascinam o homem com o seu impressionante número. Em um outro universo, o nosso universo biológico interno, uma gigantesca 'galáxia' com centenas de milhões de pequenas células nervosas que formam o cérebro e 0 sistema nervoso comunicam-se umas com as outras através de pulsos eletroquímicos para produzir atividades muito especiais: nossos pensamentos, sentimentos, dor, emoções, sonhos, movimentos, e muitas outras funções mentais e físicas, sem as quais não seria possível expressarmos toda a nossa riqueza interna e nem perceber o nosso mundo externo, como o som, cheiro, sabor, e também luz e brilho, inclusive o das estrelas.(CARDOSO, 1998).

Mesmo leigos na área de neurociência, sem o domínio do vocabulário 
específico normalmente utilizado, com o uso da imaginação são capazes de visualizar a complexidade e a magnífica competência do sistema nervoso exercendo sua função. A sensação é de estar ouvindo uma orquestra, muita bem ensaiada, executando uma complexa sinfonia.

Portanto, apenas imagine as situações que são descritas a seguir, não se prenda ao fato de não conhecer o vocabulário específico. Num primeiro momento busque apenas compreender o sentido geral de como o sistema nervoso funciona, independente de sua complexidade. Simplesmente visualize as situações que serão descritas a seguir.

Você já deve ter batido palmas em várias situações; chamando a atenção de alguém, acompanhando uma música ou aplaudindo um espetáculo com diferentes intensidades e ritmos. Mesmo algo tão simples e corriqueiro, como o bater de palmas, requer a atividade coordenada entre milhões de neurônios. Se você estivesse realizando uma Ressonância magnética funcional ${ }^{10}$ (RMf), as imagens produzidas do seu cérebro em ação mostrariam áreas distintas iluminadas, significando que estas consomem mais energia durante a atividade de bater palmas. Em outras palavras, as áreas que aparecem iluminadas são as regiões do seu cérebro que estão mais ativas enquanto você bate palmas.

Bater palmas ativaria grupos de neurônios em pelo menos três áreas distintas do encéfalo ${ }^{11}$ : o córtex frontal, ativado ao se tomar decisões conscientemente; o córtex motor, que emite as instruções para que os braços e mãos se movimentem; e o cerebelo, que supervisiona o processo inteiro e ajusta suas ações para que se apresentem adequadas às necessidades externas, tais

\footnotetext{
${ }^{10}$ Técnica utilizada atualmente para fazer exames de imagens do funcionamento cerebral, em tempo real, enquanto a pessoa faz ou sente alguma coisa.

${ }^{11} \mathrm{O}$ encéfalo é formado por três órgãos: o cérebro, o tronco encefálico e o cerebelo. Portanto o cérebro é o principal órgão constituinte do encéfalo.
} 
como o posicionamento de uma mão em relação à outra.

E, se você estivesse recordando algo do seu passado, do momento em que conseguiu andar de bicicleta sozinho, estaria ativando o hipocampo, uma das estruturas no interior do encéfalo envolvida no processamento da memória; mas como andar de bicicleta é também uma atividade motora, é provável que regiões relacionadas com as áreas motoras também se iluminem.

Recordar o cheiro da terra molhada depois de uma chuva ativa áreas relacionadas à memória e ao bulbo olfativo. E como essas memórias geralmente trazem um componente emotivo, entra em atividade o sistema límbico, que inclui o hipotálamo e a amígdala.

Claro que o sistema nervoso funciona continuamente. Alterando apenas a intensidade e as modulações geradas por uma extensa atuação de neurotransmissores e receptores nas transmissões sinápticas.

O encéfalo funciona em um sistema integrado, raramente uma parte funciona isolada. Estas partes apenas foram descritas separadamente para facilitar a visualização e o entendimento de suas funções e a forma como se relacionam.

Por exemplo, o homem, ao tocar um violino, ativa simultaneamente várias áreas encefálicas (córtex motor, córtex sensorial e áreas de associação), para realizar a mesma ação, conforme ilustra a figura a seguir.

Tocar violino é a expressão de um comportamento complexo. O comportamento pode ser definido como qualquer tipo de movimento em um organismo vivo. Assim sendo, o comportamento tem tanto uma causa como uma função. Embora a flexibilidade e a complexidade de um comportamento possam variar muito, o encéfalo é o órgão que exerce o controle destas funções. O encéfalo pode ser comparado a um maestro, que organiza e utiliza continuamente a atividade 
sensorial e motora para executar uma sinfonia. Neste exato momento, o seu encéfalo está executando a sua sinfonia!

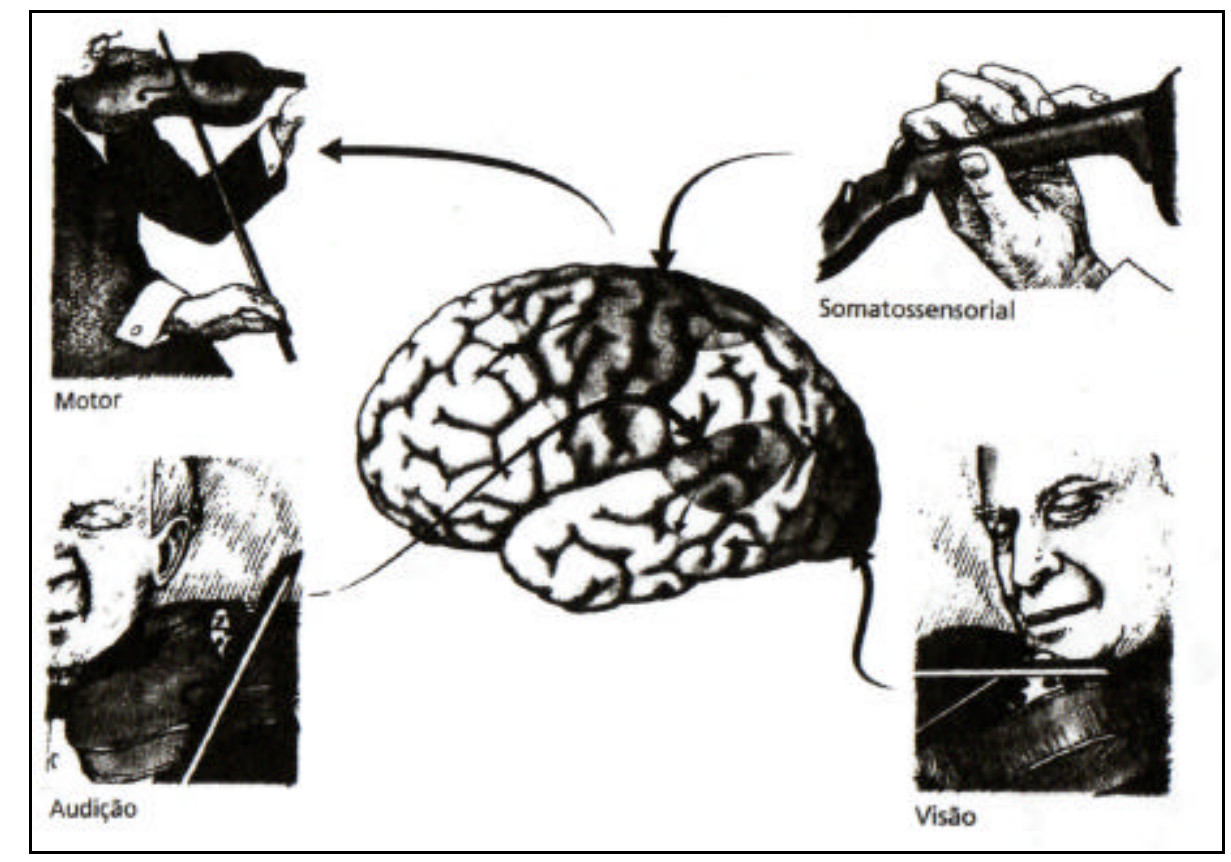

\subsubsection{A organização do sistema nervoso e processamento da informação} neural

Acordar, trabalhar, comer, divertir-se, andar, dormir, sonhar, sentir e, inclusive, imaginar, são atividades realizadas e coordenadas por nosso sistema nervoso. O sistema nervoso é responsável pelo ajustamento do organismo ao ambiente. Sua função é perceber e identificar as condições ambientais externas, bem como as condições reinantes dentro do próprio corpo e elaborar respostas que adaptem a essas condições. 


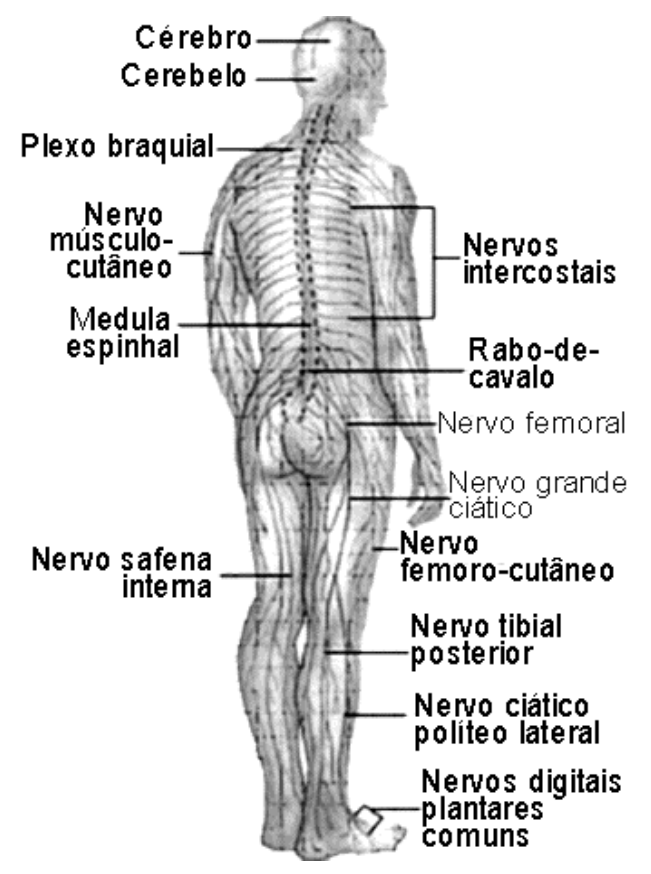

Para realizar uma variedade tão grande de atividades, o sistema nervoso se ramifica por todo o corpo. Ele está subdividido em Sistema Nervoso Periférico (SNP) e Sistema Nervoso Central (SNC), conforme mostra o quadro abaixo. Neste trabalho, será enfocado apenas o funcionamento do sistema nervoso central e como se relacionam os neurônios, os estados mentais, o conhecimento e a aprendizagem.

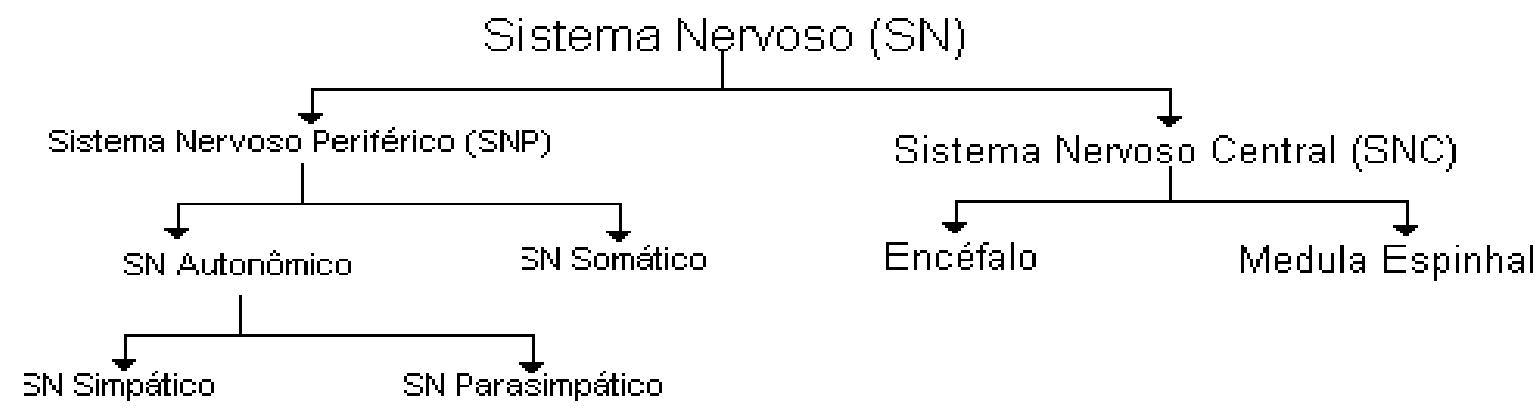

O encéfalo é formado por três componentes: o cérebro, o tronco encefálico e o cerebelo.

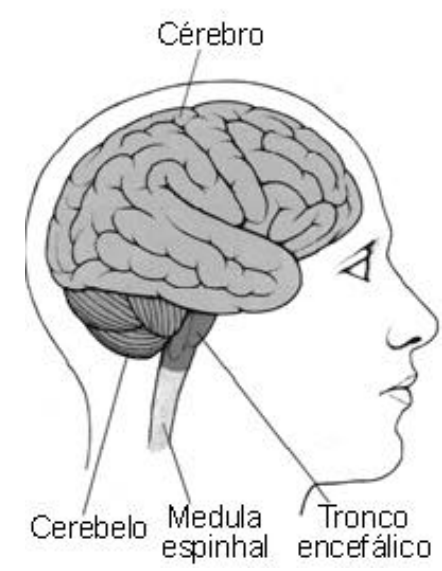

O tronco encefálico regula automaticamente funções fundamentais do organismo. Ele auxilia no ajuste da postura, no controle da respiração, da deglutição e do ritmo cardíaco, no controle da velocidade com que o organismo consome os alimentos e no aumento do estado de vigília em caso de necessidade. 
O cerebelo, localizado abaixo do cérebro e imediatamente acima do tronco encefálico, coordena os movimentos do corpo. Com a informação que recebe do cérebro e a informação sobre a posição dos membros superiores e inferiores e sobre seu grau de tônus muscular, o cerebelo auxilia o corpo a realizar movimentos suaves e precisos.
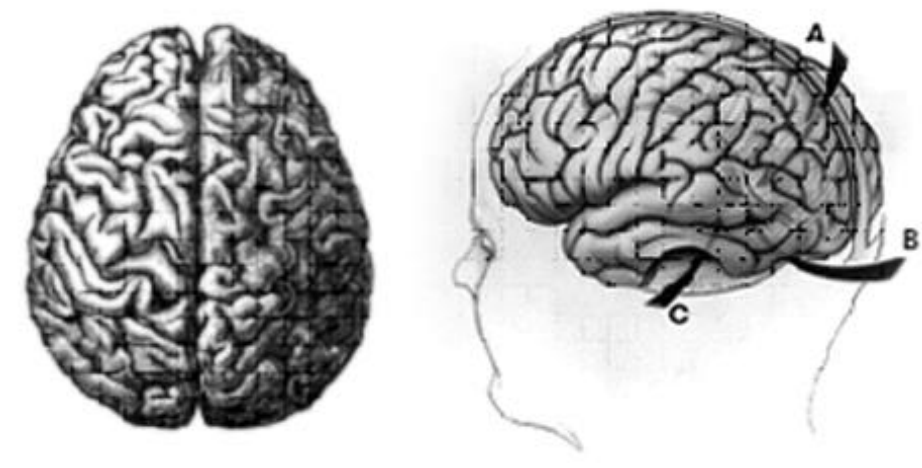

O cérebro é dividido em duas metades — os hemisférios cerebrais esquerdo e direito - conectadas, em sua parte central, por fibras nervosas conhecidas como corpo caloso. O corpo caloso atua como ponte, permitindo que os hemisférios troquem informações.

Cada hemisfério, por sua vez, é dividido em lobos, que se especializam em diferentes tarefas.

- Lobo frontal (frente) - Responsável pela elaboração do pensamento e planejamento da ação.

- Lobo Parietal (alto) - Relaciona-se com a sensação e o processamento espacial.

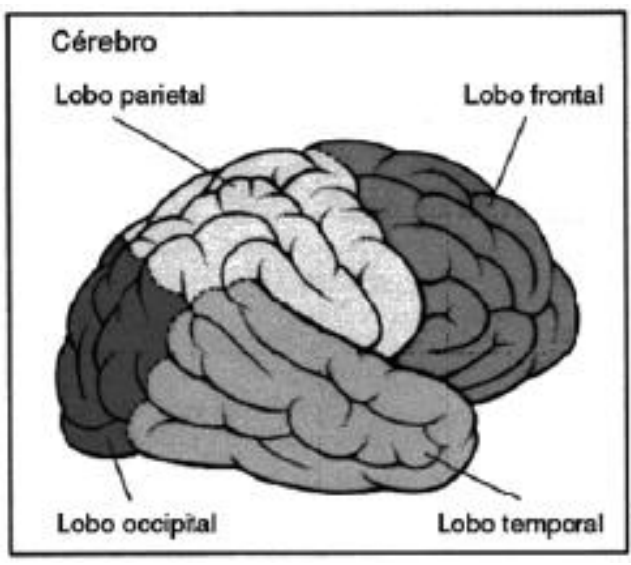

- Lobo temporal (lateral) - É relacionado primariamente com o sentido de audição, possibilitando o reconhecimento de tons específicos e intensidade do som. Tumor ou acidente afetando esta região 
provoca deficiência de audição ou surdez. Esta área também exibe um papel no processamento da memória e reconhecimento de objetos.

- Lobo Occipital (parte de trás) - Responsável pelo processamento da informação visual. Danos nesta área promovem cegueira total ou parcial.

Diferentes partes do cérebro desempenham diferentes tarefas de processamento de informações. Esse princípio da localização funcional se revela verdadeiro em quase todos os níveis de organização cerebral. O cérebro é um conjunto de estruturas que se situa no topo da coluna vertebral. As estruturas inferiores se empenham em coordenar as funções corporais básicas (respiração, digestão, movimentos voluntários, por exemplo), a expressar os impulsos básicos (como fome e desejo sexual) e processar as emoções primárias (medo, por exemplo). As estruturas superiores, que evoluíram mais tarde e por cima das estruturas inferiores, são mais desenvolvidas nos humanos que em qualquer outro animal. A parte de evolução mais recente, o neocórtex, é uma camada fina de neurônios que envolvem a superfície do cérebro. É aí que o pensamento ocorre e onde residem três quartos dos neurônios de um cérebro humano.

Naturalmente, essa é uma caracterização genérica, já que cada lobo se subdivide em redes interligadas de neurônios especializados em cada processamento específico da informação. Tarefas complexas, como adição ou reconhecimento de palavras, dependem da ação coordenada de várias dessas redes neurais especializadas, localizadas em diferentes partes do cérebro. Qualquer dano a uma dessas redes ou às conexões entre elas pode deteriorar a capacidade 
que elas coordenam, e para cada anomalia corresponde um déficit específico.

A unidade
básica do sistema nervoso é
a célula nervosa,
denominada neurônio.
Sendo unidades funcionais
de informação, os neurônios

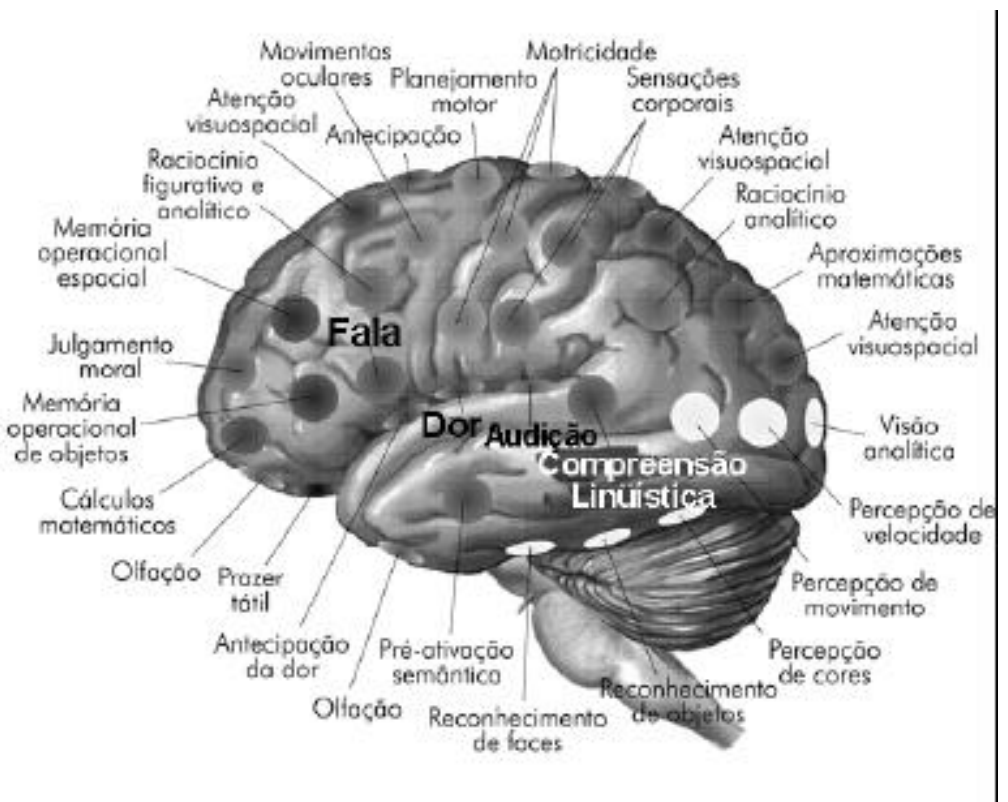
operam em grandes conjuntos, e não isoladamente. Esses conjuntos de neurônios associados formam os chamados circuitos ou redes neurais. Por exemplo, os neurônios da retina, que captam as imagens formadas pela luz ambiente, só se tornam capazes de propiciar a visão se veicularem os sinais elétricos que geram em resposta à luz a outros neurônios localizados na própria retina e depois no cérebro. Cada um deles realiza uma pequena parte do trabalho cooperativo que ao final possibilitará ler um livro, ver um filme ou admirar uma obra de arte.

O neurônio, que é uma célula extremamente estimulável, é capaz de perceber as mínimas variações que ocorrem em torno de si, reagindo com uma alteração elétrica que percorre sua membrana. Essa alteração elétrica é o impulso nervoso.

Cada neurônio pode conectar-se a milhares de outros, permitindo que os sinais da

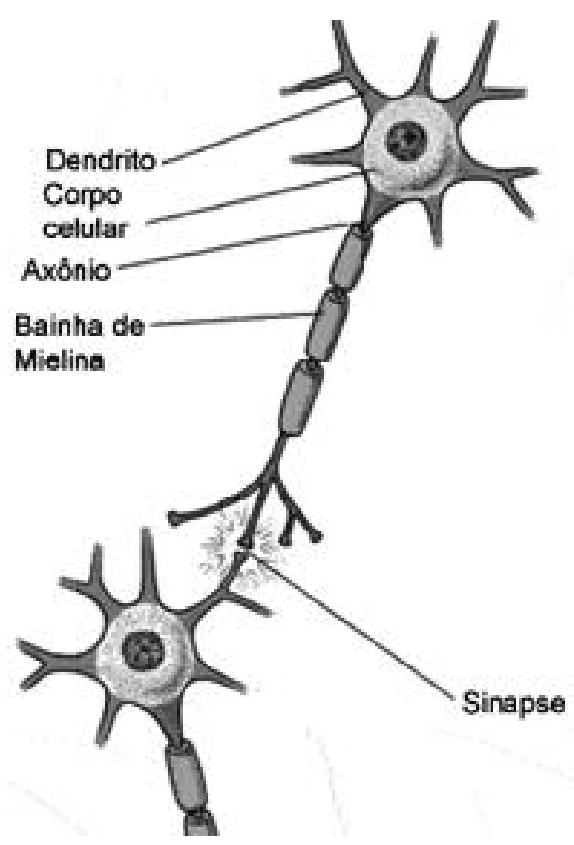


informação fluam em grande quantidade e em muitas direções ao mesmo tempo.

Existem diversos tipos de neurônios, com diferentes funções dependendo da sua localização e estrutura morfológica, mas em geral constituem-se dos mesmos componentes básicos:

- o corpo do neurônio (soma), constituído de núcleo e pericário, que dá suporte metabólico à toda célula;

- o axônio (fibra nervosa) é o prolongamento único e grande que aparece no soma. É responsável pela condução do impulso nervoso para o próximo neurônio, podendo ser revestido ou não por mielina;

- os dendritos são prolongamentos menores em forma de ramificações (arborizações terminais) que emergem do final do axônio, sendo, na maioria das vezes, responsáveis pela comunicação entre os neurônios através das sinapses.

Além dos neurônios, o sistema nervoso apresenta-se constituído pelas células glia, ou células gliais, cuja função é dar sustentação aos neurônios e auxiliar

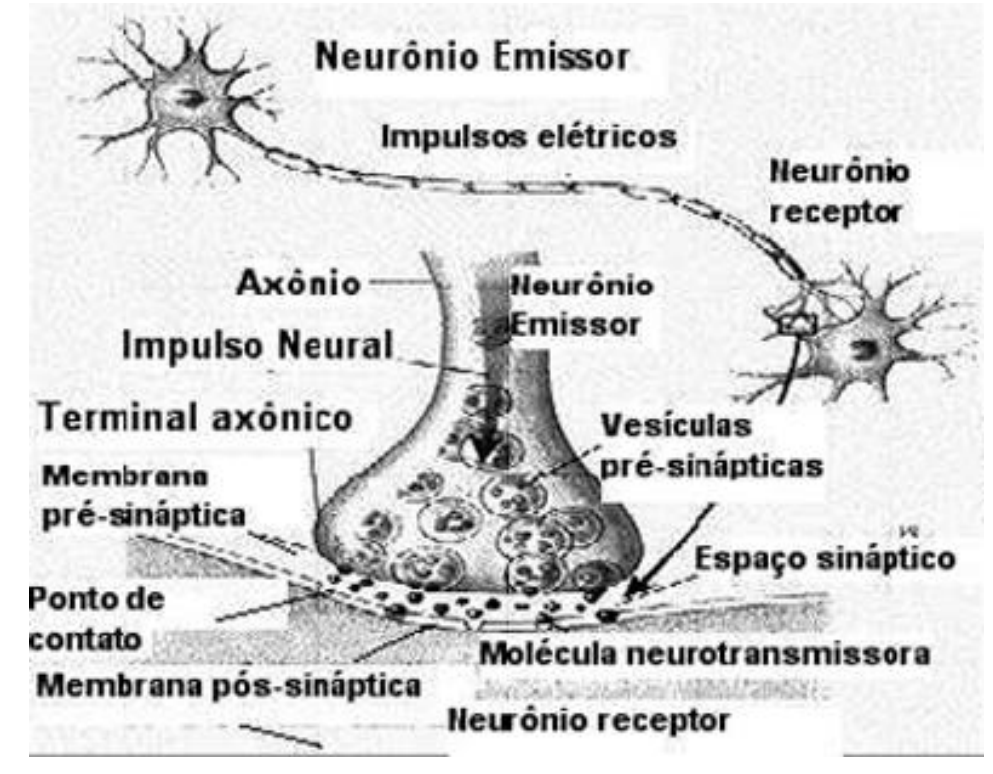

o seu funcionamento. As células da glia constituem cerca de metade do volume do nosso encéfalo. Há diversos tipos de células gliais. Os astrócitos, por exemplo, dispõem-se ao longo dos capilares sanguíneos do encéfalo, controlando a 
passagem de substâncias do sangue para as células do sistema nervoso. Os oligodendrócitos e as células de Schwann enrolam-se sobre os axônios de certos neurônios, formando envoltórios isolantes denominados como bainha de mielina.

O cérebro contém aproximadamente 100 bilhões de neurônios e trilhões de células da glia. No espaço de contato entre os neurônios (sinapse ${ }^{12}$ ), o axônio que transmite a informação secreta uma pequena quantidade de substâncias químicas, denominadas neurotransmissores. Essas substâncias estimulam os receptores localizados no dendrito do neurônio seguinte para que este inicie uma nova corrente elétrica. Diferentes tipos de nervo utilizam diferentes neurotransmissores para transmitir informações através das sinapses. O axônio poderá estar envolto por um tipo de isolante, a bainha de mielina, cuja função é semelhante ao isolamento dos fios elétricos.

Num dado momento, um grande número de neurônios entra em atividade simultaneamente, e cada um dos chamados "padrões de atividade" corresponde a um determinado estado mental. À medida que a eletricidade flui através das conexões entre neurônios (sinapses), enviando a sinalização em códigos, outro conjunto de neurônios é ativado e o cérebro passa a outro estado mental. Ao contrário dos bits do computador, que estão ligados ou desligados, o nível de ativação dos neurônios muda continuamente, permitindo variações incrivelmente sutis do estado mental.

Sendo os estados mentais produzidos por padrões de atividade neural, o conhecimento, definido como aquilo que dirige o fluxo cognitivo de um estado mental para outro, deve ser codificado nas conexões neurais. Isso significa que a aprendizagem se dá seja pelo crescimento de novas sinapses, seja pelo

${ }^{12}$ Sinapses são junções formadas com outras células nervosas onde o terminal pré-sináptico de uma célula faz contato com a membrana pós-sinaptica de outra. São nestas junções que os neurônios são excitados, inibidos ou modulados. Existem dois tipos de sinapses, a elétrica e a química. 
fortalecimento ou enfraquecimento das sinapses existentes. Na verdade, há evidência de ambos os mecanismos, o primeiro mais presente nos cérebros jovens; o segundo, nos cérebros mais maduros. Vale notar que a entrada de qualquer novo conhecimento de longo prazo no cérebro requer a modificação de sua anatomia.

\subsubsection{Neurônios-espelho}

Existem diversos tipos de neurônios, com diferentes funções dependendo da sua localização e estrutura morfológica. Entre eles estão a célula de purkinge, o neurônio estrelado, o neurônio unipolar, neurônio piramidal, neurônio multipolar, neurônio monopolar visual, o interneurônio, o motoneurônio e tantos outros.

Uma das descobertas mais importantes das neurociências nos últimos tempos são os chamados neurônios-espelho. Os neurocientistas que os descobriram são Giacomo Rizzolatti e colaboradores, da Universidade de Parma, na Itália. Estes neurônios foram primeiramente encontrados nas áreas do córtex préfrontal de macacos. São neurônios que disparam (entram em atividade acentuada) não apenas quando o animal realiza a ação (o que já era previsto que acontecesse), mas também disparam quando o animal está apenas observando uma outra pessoa realizar a ação (o que foi uma surpresa). O artigo relatando essa importante descoberta foi publicado em 1996.

Desde então, várias equipes pesquisaram o papel dos neurôniosespelho no movimento e em outras funções. Agora, no entanto, o foco dos pesquisadores está naquilo que parece ser uma função adicional dessas células - a maneira como disparam em resposta a algo observado. A descoberta desse 
mecanismo, feita há cerca de uma década, sugere que nós também fazemos mentalmente tudo a que assistimos alguém fazer. Ela explica como aprendemos a sorrir, conversar, caminhar, dançar ou mesmo jogar tênis.

Numerosas pesquisas têm demonstrado que o cérebro humano tem múltiplos sistemas de neurônios-espelho especializados em executar e compreender não apenas as ações dos outros, mas também as suas intenções, o significado social do comportamento deles e suas emoções. Os neurônios-espelho já foram encontrados nas áreas do córtex pré-motor e parietal inferior (associados a movimentos de percepção), bem como no lobo parietal posterior, no sulco temporal superior e na ínsula, regiões que correspondem a nossa capacidade de compreender o sentimento de outra pessoa, entender a intensão e usar a linguagem.

Numerosas pesquisas têm demonstrado que o cérebro humano tem múltiplos sistemas de neurônios-espelho especializados em executar e compreender não apenas as ações dos outros, mas suas intenções, o significado social do comportamento deles e suas emoções. Os neurônios-espelho já foram encontrados nas áreas do córtex pré-motor e parietal inferior (associados a movimentos de percepção), bem como no lobo parietal posterior, no sulco temporal superior e na ínsula, regiões que correspondem a nossa capacidade de compreender o sentimento de outra pessoa, entender a intenção e usar a linguagem.

Encontradas em várias partes do cérebro, essas células disparam em resposta a cadeias de ações relacionadas a intenções. Algumas são acionadas quando uma pessoa estende a mão para pegar um copo ou observa alguém pegar um copo; outras disparam quando a pessoa coloca o copo sobre a mesa e, outras ainda, quando a pessoa estende a mão para pegar uma escova de dente e etc. 
Descobriu-se também que os seres humanos têm neurônios-espelho muito mais perspicazes, flexíveis e altamente evoluídos do que os encontrados nos macacos, um fato que teria resultado na evolução de habilidades sociais mais sofisticadas nos seres humanos.

Em entrevista ao jornal norte-americano New York Times, Rizzolatti (apud: DOBBS, 2006, p. 46-51) disse: "Somos criaturas requintadamente sociais. Os neurônios-espelho nos permitem captar a mente dos outros não por meio do raciocínio conceitual, mas pela simulação direta. Sentindo e não pensando".

Em 1998, Rizzolatti e Arbib descobriram que uma das regiões particularmente ricas em neurônios-espelho é a área de Broca ${ }^{13}$. Segundo Michael Arbib, neurocientista da University of Southern California, toda a linguagem pode estar baseada no funcionamento dos neurônios-espelho. Tal sistema, encontrado na parte frontal do cérebro, contém circuitos superpostos para a língua falada e a linguagem dos sinais. Num artigo publicado na revista Trends in Neuroscience, em março de 1998, Arbib descreve como gestos de mão e movimentos complexos da língua e dos lábios usados na formação de sentenças fazem uso do mesmo mecanismo.

Para Vilayanur Ramachandran (MENTE \& CÉREBRO, 2006, no 161), neurocientista da Universidade da Califórnia de San Diego, os neurônios-espelho vão fazer pela psicologia o que o DNA fez pela biologia: um sistema de referências unificador capaz de explicar o funcionamento de nossa mente. Daí, por exemplo, podermos compreender como os seres humanos deram "um grande salto à frente" cerca de 50 mil anos atrás, quando adquiriram novas habilidades que tornaram possível a cultura humana, como o uso de linguagem, de ferramentas e da arte. Até

\footnotetext{
${ }^{13}$ Área responsável pelo processamento da linguagem.
} 
então, os estudiosos vinham tratando a cultura como fundamentalmente separada da biologia. Patricia Greenfield (MENTE\&CÉREBRO, 2006, nº 161), psicóloga da UCLA, considera que "Agora vemos que os neurônios-espelho absorvem a cultura diretamente, com cada geração ensinando a próxima por meio do convívio social, imitação e observação".

Dado que os neurônios-espelho são tão fundamentais para a compreensão, faz sentido que falhas entre eles possam criar problemas profundos. De fato, parece que déficits podem ajudar a explicar dificuldades que vão de reserva excessiva a autismo. Alguns cientistas acreditam que o autismo pode estar relacionado a neurônios-espelho malformados. No artigo publicado na revista "Nature Neuroscience", de autoria de Mirella Dapretto, neurocientista da UCLA, revela que, embora muitas pessoas autistas consigam identificar expressões emocionais, como a risteza no rosto de outra pessoa, e até mesmo imitar olhares tristes, não percebem o significado emocional da emoção imitada. Mesmo observando outras pessoas, não sabem como é se sentir triste, com raiva, desgostoso ou surpreso.

Os neurocientistas Gallese \& Goldman, em estudo divulgado na revista especializada Trends in Cognitive Sciences (1988, p. 493-501), sugerem que os neurônios-espelho são acionados ao vermos alguém bocejar ou mesmo rir. Isso explicaria tanto o riso como o bocejo contagioso. Deste modo, os neurônios-espelho não agiriam apenas ao observar um gesto ou uma emoção, mas seriam acionados também pelo simples som dela.

As investigações com neurônios-espelho aumentaram bastante nos últimos cinco anos, e parece certo que irá crescer ainda mais. Se seu enorme poder explicativo for apoiado em resultados mais robustos, esses neurônios poderão ser 
tratados como o DNA da neurociência. Enquanto isso, os neurônios-espelho explicam algumas maravilhas intrigantes.

\subsubsection{Emoção e o sistema límbico}

Não é possível entender quem somos ou como interagimos com o mundo sem considerar a nossa vida emocional. $E$ todas as emoções têm um correlato neural. Feliz, triste, medroso, ansioso, exultante, abalado, desapontado, culpado, apaixonado são alguns termos usados para descrever os estados emocionais. Nossa linguagem, utilizada para denominar as emoções, é rica e variada. O desafio da neurociência é estudar os componentes da comunicação neuronal necessários para gerar os estados emocionais.

As mesmas emoções que geram alterações fisiológicas como: alterações na freqüência cardíaca, na pressão sanguínea e nas secreções hormonais incluem também certas reações motoras, principalmente movimentos dos músculos faciais para produzir expressões. Assim como são também as emoções que estão no âmago da expressão artística, desde a poesia, passando pelo cinema, até a pintura. De fato, uma razão pela qual as pessoas apreciam a arte é que ela evoca emoções, que independente de serem agradáveis ou desagradáveis, foram habilmente captadas, reordenadas e transmitidas nas obras de arte.

\subsubsection{Localização encefálica do sistema límbico}

No interior do encéfalo, há um conjunto de estruturas coletivamente conhecido como sistema límbico, responsável pelo comportamento emocional. As 
principais estruturas desse sistema são a amígdala, o hipocampo, os corpos mamilares e o giro do cíngulo. Essa região do encéfalo também tem sido chamada de cérebro emocional e estabelece conexões com o córtex frontal.

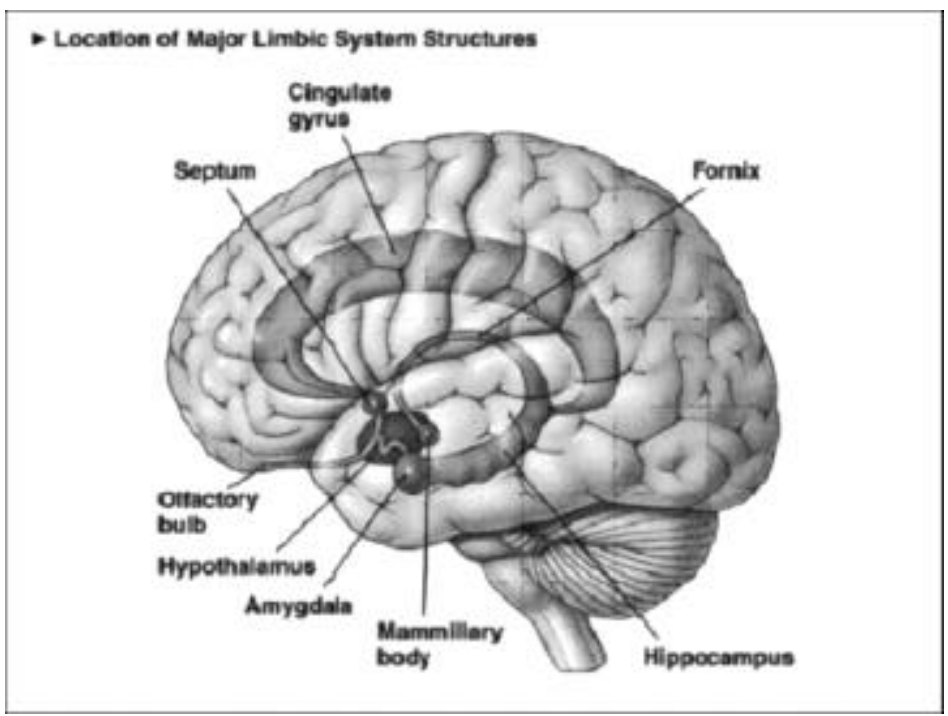

Quando essas
conexões são danificadas ou
alteradas devido a tensão ou
medo, o discernimento social é
prejudicado, assim como o
desempenho cognitivo, porque
os aspectos emocionais da
aprendizagem, inclusive a

reação à recompensa e ao risco, ficam comprometidos. Existem exemplos clínicos, citados por Antonio Damásio (DAMÁSIO, 1996) em que a interação entre a parte emocional e a parte cognitiva do cérebro ficou prejudicada em casos de lesão. Suzana Herculano-Houzel, neurocientista da Fiocruz, no Rio de Janeiro, relata que:

Damásio transformou as emoções, seu principal interresse de estudo, em um tema legítimo da neurociência experimental. Em suas mãos, o que antes era tradicionamente domínio exclusivo da psicologia e da filosofia, por ser considerado assunto puramente subjetivo e, portanto, imensurável, passou a ter bases biológicas. Para ele, a emoção não é uma abstração mental, mas um processo que envolve corpo e cérebro, uma idéia que ele expôs no livro $O$ erro de Descartes. Além de demonstrar como as emoções contribuem na tomada de decisões, Damásio propõe que elas nascem da interação entre o corpo e o cérebro, e sugere que emoção, na verdade, é uma seqüência de dois processos: ter uma emoção, e depois senti-la. Ter uma emoção seria o que acontece quando o cérebro, induzido por uma lembrança, uma cena ou uma situação real, provoca alterações 
no corpo - aceleração dos batimentos cardíacos, suor, queda da pressão arterial, por exemplo. Sentir a emoção, ou ter um sentimento, é o que aconteceria no passo seguinte, quando o cérebro registra aquelas alterações no corpo (HERCULANOHOUZEL, 2004, p142)

Damásio enfatizou um aspecto importante da ligação entre emoção e fatores cognitivos, em sua hipótese do marcador somático ${ }^{14}$. Esta hipótese determina que sinais "marcadores" surgidos de emoções e sentimentos agem para guiar o comportamento e as tomadas de decisões, em um processo que se estabelece normalmente de modo inconsciente.

Em outras palavras, a hipótese do marcador somático de Damásio sugere como as emoções estão normalmente ligadas a pensamentos, decisões e ações de uma pessoa. Em um estado emocional típico, certas regiões do encéfalo enviam mensagens a muitas outras áreas encefálicas e a grande parte do restante do corpo por meio de hormônios e do sistema nervoso autônomo. Essas mensagens produzem uma alteração global no organismo, e esse estado alterado influencia o comportamento, geralmente de maneira inconsciente.

Competência emocional inclui - mas não se limita a - a capacidade de estar consciente de si mesmo, de autocontrole e compaixão, de resolver œnflitos e cooperar. Psicologicamente, o processo emocional é rápido, automático, não filtrado pela atenção, e corresponde ao que alguns descrevem como impulsivo. Aspectos desse processo emocional constituem o temperamento ou a personalidade do indivíduo. Esses aspectos, geralmente, escapam à instrução cognitiva normal, mas

\footnotetext{
${ }^{14}$ A hipótese do marcador somático tem mais ou menos a seguinte forma: Indivíduos normais ativam os chamados "estados somáticos" (alterações na freqüência cardíaca e respiração, dilatação das pupilas, sudorese, expressão facial, etc.) em resposta à punição associada às situações sociais. Por exemplo, uma criança quebra alguma coisa valiosa e é punida severamente por seus pais, evocando estes estados somáticos. Da próxima vez que ocorrer uma situação similar, os marcadores somáticos são ativados e a mesma emoção associada à punição é sentida. De modo a evitar isto, a criança suprime o comportamento indesejado.
} 
tornam-se importantes quando se enfrenta uma situação vivencial ou educacional nova. Algumas pessoas demonstram medo quando enfrentam uma nova situação; outras mostram frustração; outras uma excitação positiva.

Pesquisas sobre a função da amígdala e o processo emocional estão permitindo aos pesquisadores entender a complexidade envolvida na aquisição da competência emocional, uma vez que ela exige uma comunicação entre a parte emocional e cognitiva do cérebro. Em breve, esses resultados poderão sugerir várias abordagens interessantes a serem utilizadas no sistema educacional.

\subsubsection{Imaginação}

A imaginação é um fenômeno cognitivo, estudado primeiramente por Wilhelm Wundt na virada do século XX. A habilidade em criar e experimentar situações virtuais, de combinar informações de forma pouco comum ou de inventar imagens mentais sempre foi alvo de muita controvérsia entre filósofos e psicólogos.

No período que vai das primeiras décadas do século $X X$ ao início dos anos 70 , a hegemonia das pesquisas behavioristas impediu a continuidade da investigação das representações mentais. Somente com Roger Shepard, na universidade Stanford, o tema das representações pictóricas voltou a ser pesquisado numa série de experimentos envolvendo a rotação de imagens. Os resultados advindos dessas pesquisas reintroduziram o tema das representações pictóricas no centro das atenções da ciência cognitiva.

Então, Steven Kosslyn, psicólogo cognitivo da Universidade de Harvard, partiu da iniciativa de Shepard para empreender novos testes que visavam ampliar o número de provas empíricas sobre a existência e flexibilidade da imagética 
mental.

Após uma série de pesquisas, Kosslyn propôs, então, uma teoria imagética sobre as representações mentais figurativas, na qual as imagens são tão importantes para compreensão da cognição quanto o método proposicional.

O psicólogo canadense Zenon Pylyshyn não ficou nada satisfeito com o retorno do modelo imagético. Para Pylyshyn, o processo cognitivo é totalmente computacional e o comportamento do sistema pode ser explicado por propriedades intrínsecas de leis biológicas. Em outras palavras, os cientistas descutiam se a imaginação usava regiões específicas do cérebro, ou se ela apenas reativava as partes do cérebro usadas pelos sentidos. Conforme Suzana Herculano-Houzel comenta:

Aos poucos, e graças à engenhosidade e insissistência de Kosslyn, no meio dos anos 90, foi ficando claro que imaginar, 'ver com os olhos da mente', é ativar a visão pelo lado de dentro: sem que haja um estímulo para os olhos, a imaginação faz funcionar as partes do cérebro que vêem. Kosslyn usou máquinas de imageamento cerebral, que detectam quais partes do cérebro consomem mais energia enquanto a pessoa faz, ou sente, alguma coisa. Mas o que ele pediu aos seus voluntários era até então impensável num experimento científico: que imaginassem ver as figuras que ele tinha acabado de mostrar. Afinal, como saber o que a pessoa tinha realmente imaginado? Era um experimento em que o pesquisador não controlava praticamente nada. No entanto, os resultados eram consistentes de uma pessoa para outra. Kosslyn foi experimentando com as mais diferentes tarefas: imaginar objetos conhecidos, rostos, figuras novas, o caminho de casa. Em todos os casos, o cérebro se comportava como se a pessoa estivesse "vendo", apesar de ter os olhos fechados. Imaginar uma letra minúscula, por exemplo, ativava uma região menor nas áreas visuais no cérebro que imaginar letras maiúsculas - exatamente como quando vemos letras de tamanhos 
diferentes. E agora, no final do ano 2000, foi encontrada a pista que faltava: ver ou imaginar objetos acaba ativando os mesmos neurônios no cérebro. O experimento foi feito por dois pesquisadores da Caltech, associados a um neurocirurgião da Universidade da Califórnia. Juntos eles estudaram nove pacientes que sofriam de epilepsia intratável, e por isso foram submetidos a uma cirurgia para a implantação no cérebro de eletrodos que permetiriam a localização do foco da doença. Ao posicionar os eletrodos, os pesquisadores aproveitaram para analisar a atividade de neurônios ao redor, enquanto pediam aos pacientes para olharem figuras e depois imaginá-las ${ }^{15}$ (HERCULANO-HOUZEL, 2004, p152).

Imaginação é a representação mental das coisas (objetos, eventos, ambientes, etc.) que presentemente não estão sendo percebidas pelos órgãos sensoriais. Por exemplo, recorde uma de suas primeiras experiências na escola. Quais foram algumas das visões, dos sons e até dos aromas que você teve naquela ocasião? Embora essas sensações não lhe sejam imediatamente acessíveis nesse momento, ainda assim você pode imaginá-las. De fato, a imaginação mental pode representar coisas que jamais haviam sido observadas pelos seus sentidos em momento algum; por exemplo, imagine o que seria estar andando no deserto do Saara. As imagens mentais podem, mesmo, representar coisas que absolutamente não existem fora da mente da pessoa que as cria; exemplificando, o avião antes de haver sido criado por Santos Dumont.

A maioria das pesquisas sobre a imaginação, na psicologia cognitiva, focalizou a imaginação visual, a representação mental do conhecimento visual (p.ex., objetos ou ambientes) não-visível presentemente aos olhos.

Pesquisas recentes demonstraram que a imaginação pode envolver

\footnotetext{
${ }^{15}$ Os pacientes costumam ficar acordados durante a cirurgia do cérebro, pois o cérebro não tem receptores de dor.
} 
representações mentais em quaisquer modalidades sensoriais (audição, olfato, paladar, etc.) não apenas na modalidade visual. Imagine um alarme de incêndio, sua canção favorita; o aroma de um perfume, de bacon frito ou de uma cebola; o sabor de um limão, ou de seu doce favorito. Pelo menos hipoteticamente, cada forma de representação mental está sujeita à investigação e alguns cientistas estudaram cada uma das representações sensoriais.

Kosslyn, no momento, está conduzindo experimentos que mostram que o cérebro emocional tem conexões com as regiões perceptivas do cérebro. Uma dessas partes do cérebro, o lobo occiptal, não só está engajado na percepção, mas também na construção de imagens mentais ou visualização. Pesquisas que utilizam as técnicas de neuroimagem funcional têm mostrado, repetidamente, que o ato de imaginar ou visualizar ativa muitas das mesmas regiões do cérebro ativadas pela percepção.

Recentes pesquisas que utilizaram neuroimagens funcionais mostraram que, quando os sujeitos visualizavam estímulos aversivos (por exemplo, um rosto espancado ou um corpo queimado), certas regiões do cérebro ficavam mais ativas do que quando o sujeito visualizava estímulos neutros (por exemplo, uma lâmpada ou uma cadeira). Essas regiões, inclusive a ínsula anterior (dentro do sistema límbico), são responsáveis pelo registro de mudanças autônomas no corpo. Como o Dr Stephen Kosslyn observou em sua palestra no Fórum de Alto Nível, realizado pela OCDE, na Espanha em 2001, a pesquisa está começando a demonstrar que a visualização de fatos aversivos não só é registrada no cérebro, mas também afeta o corpo alterando o sistema hormonal. Isso pode afetar indiretamente as capacidades cognitivas, uma vez que o nível de testosterona afeta a capacidade espacial. Vencer uma competição eleva o nível desse hormônio no 
sangue, enquanto uma derrota baixa o nível do hormônio. Portanto, é possível que a simples visualização de tais situações também possam afetar esse hormônio, que, por sua vez afetaria as capacidades espaciais. Atualmente, várias equipes de pesquisadores estão envolvidas no andamento dessa modalidade de investigação científica.

Para os arte educadores, o uso da imaginação na aprendizagem tem sido desde sempre uma força pedagógica. Afinal, mesmo antes de sabermos os mecanismos neurais da imaginação, o ser humano naturalmente já a utilizava a milênios.

Porém, o acesso aos resultados de pesquisas científicas referentes ao processo cognitivo da imaginação pode trazer informações valiosas a serem incorporadas na área pedagógica.

Portanto, reforço a sugestão: Imagine, apenas imagine, 0 funcionamento do Sistema Nervoso!

Entre nossas características culturais únicas, a arte é talvez a mais nobre invenção humana. Imaginem, por exemplo, a necessidade de recrutamento de bilhões de neurônios, milhares de músculos, imensa capacidade sensorial, visual e auditiva, a espantosa capacidade de memória envolvida para saber de cór e executar um concerto para tocar uma serenata de Chopin ao piano. São bilhões e bilhões de neurônios, treinados ao longo de anos de prática, espalhados por todas as regiões do cérebro, e trabalhando em harmonia para produzir um resultado de uma complexidade inimaginável. (CARDOSO \& SABBATINI, 2000). 


\subsection{Percepção, um panorama sensorial}

Nibil est in intellectu quod prius non fuerit in sensu.

Não há nada na nossa mente, do mundo que nos circunda, que não tenha passado pelo nosso aparelho sensorial.

O estudo de como se dá a percepção, de como se relacionam aspectos psicológicos e neurofisiológicos na captação, interpretação e construção dos estímulos sensoriais é de importância simplesmente fundamental. Afinal, tudo que nós sabemos sobre o mundo vem-nos com nossos sentidos. É através da percepção que realizamos a conexão entre o mundo exterior e o mundo interior.

As sensações são a porta de entrada do mundo em nosso organismo. E a ordenação dessas sensações, através de uma construção dotada de um sentido pessoal, é a percepção. Portanto, a percepção apresenta um nível de complexidade mais alto do que a sensação, e por isso mesmo ultrapassa os limites estruturais dos sistemas sensoriais, envolvendo também outras partes do sistema nervoso, de funções não-sensoriais.

Através da percepção, construímos e ordenamos perceptos, compondo um mundo que nos faz sentido e no qual podemos interagir.

Desde o tempo dos filósofos gregos, pensadores de cada geração têm se perguntado: Como a experiência interage com a organização inata da mente? Como percebemos o mundo, aprendemos uns sobre os outros e lembramos aquilo que experienciamos? Nas últimas décadas, neurocientistas têm utilizado observações experimentais de estudos biológicos da cognição para enfocar de um modo novo, algumas das questões filosóficas clássicas a respeito da natureza da mente e da experiência consciente. Conforme Bryan Kolb, neurocientista da 
University of Lethbridge no Canadá, assinalou:

Talvez o princípio mais simples das funções do encéfalo seja o fato dele ser responsável pelo comportamento. No entanto, esse princípio tem mais coisa por trás que se possa inicialmente pensar. Para que 0 encéfalo produza comportamento, ele precisa ter informações sobre o mundo ao seu redor - tamanho, formato, movimento, e assim por diante. Sem essas informações, o encéfalo não pode saber como orientar e direcionar o corpo para produzir uma resposta adequada, especialmente quando a resposta necessária for algum comportamento complexo, como apanhar uma bola. Para realizá-los, o sistema nervoso tem órgãos projetados para receber as informações do mundo e converte-las em atividade biológica capaz de produzir experiências subjetivas da realidade. Para nos movimentarmos, portanto, o encéfalo produz o que nós acreditamos ser realidade. Essas experiências subjetivas da realidade são essenciais para a execução de qualquer tarefa complexa (KOLB, 2002, p.38).

A questão da percepção se torna mais intrigante ao constatar que, o que nós percebemos com nossos sentidos não corresponde exatamente às características físicas dos estímulos ao nosso redor.

Nós recebemos ondas eletromagnéticas de diferentes freqüências, mas percebemos cores: vermelho, verde, laranja, azul ou amarelo. Recebemos ondas de pressão, mas ouvimos palavras e músicas. Entramos em contato com uma infinidade de compostos químicos dissolvidos no ar ou na água, mas sentimos cheiros e gostos.

O ser humano é constantemente bombardeado por informações sensoriais, que o atingem através de diferentes órgãos. Nestes locais, existem células receptoras especializadas que captam o tipo de energia correspondente e a 
transformam em energia elétrica. Pois esta é a energia capaz de trafegar pelo sistema nervoso e conduzir informações.

O percurso dessa sinalização elétrica em nosso organismo é ativado por uma verdadeira orquestra neuronal. Neurônios se conectaram através das sinapses envolvendo receptores e neurotransmissores numa comunicação eletroquímica. Informações foram transduzidas, enviadas, transformadas e recebidas por vias neurais, caminharam por nervos atingindo outros sistemas, até a possível finalização em um movimento muscular. É o comportamento se formado e se expressado numa ação, realizado em milissegundos e muitas vezes de modo inconsciente.

Embora todo esse sistema operando seja fantástico, ainda assim é limitado. O ser humano é capaz de captar, com o sistema sensorial, apenas uma parcela das radiações eletromagnéticas ao redor.

Todos os seres vivos têm um conjunto de sentidos que possibilitam ao organismo elaborar respostas e interagir aos estímulos do meio. Ao longo da evolução da espécie, esses sentidos foram indispensáveis para desenvolver habilidades sensitivas e propiciar a sobrevivência. Portanto, nosso sistema nervoso foi moldado por um longo período evolutivo e reage somente a uma escala reduzida de comprimento de ondas eletromagnéticas.

Ao se submeter a um exame de Raio-X não vemos nem sentimos a radiação que transpassa nosso corpo. Nós não podemos ver a luz com o comprimento de onda ultravioleta, embora as abelhas possam; assim como não podemos detectar a luz infravermelha, embora as cascavéis possam.

Com tantos desafios e atributos, a percepção sempre constituiu um tema de fascínio extremo, para onde convergiram a atenção e a contribuição de 
várias áreas através dos tempos. Entre elas a filosofia, a neurociência, a física, a fisiologia, a psicologia, a arte em geral, a educação, entre outras. Cada área apresenta seus estudos com uma maneira própria de abordagem, coerente com os métodos e perspectivas utilizadas.

Walter Freeman (2005), professor de neurobiologia, ao sintetizar em um artigo os resultados de 30 anos de trabalho com seu grupo na Universidade de Berkeley, apresenta a fisiologia da percepção como sendo o processo que permite passar da pura e simples captação de mensagens sensoriais (forma, cor, som, gosto, odor ou impressões táteis) ao reconhecimento de algo familiar e dotado de sentido.

Todo o processo perceptivo ocorre no organismo com a atuação do sistema nervoso, em particular nas regiões neurais que compõe os sistemas sensoriais. Para facilitar a compreensão é útil a definição de conceitos utilizados na área neurocientífica. Roberto Lent, neurocientista da Universidade Federal do Rio de Janeiro (UFRJ), define:

[...] sensação como sendo a capacidade que os animais apresentam de codificar certos aspectos da energia física e química que os rodeia, representando-os como impulsos nervosos capazes de ser decodificados pelos neurônios. A sensação permite a existência dos sentidos, ou seja, as diferentes modalidades sensoriais que advêm da tradução pelo sistema nervoso das diversas frmas de energia existentes no ambiente. A energia luminosa, por exemplo, em certas condições dá origem ao sentido da visão. A energia mecânica vibratória pode originar o sentido da audição, mas pode também se transformar em tato ou em dor. Sistemas sensoriais, então, representam os conjuntos de regiões do sistema nervoso, conectados entre si, cuja função é possibilitar as sensações. Percepção é um tanto diferente. Trata-se da capacidade que alguns 
animais apresentam — nem todos — de veicular os sentidos a outros aspectos da existência, como o comportamento, no caso dos animais em geral, e o pensamento, no caso dos seres humanos. O sentido da audição nos permite detectar diferentes sons, mas é a percepção auditiva que nos permite identificar, apreciar e lembrar uma música (LENT, 2004, p.169).

É na espécie humana que a percepção está mais desenvolvida, possibilitando habilidades de planejar e construir novos objetos, alguns destinados a ampliar ainda mais a sua capacidade perceptual; indagar-se sobre a origem, o passado e o futuro das coisas percebidas e até mesmo imaginar coisas imperceptíveis (mesmo na ausência de qualquer estimulação sensorial correspondente). Enfim, proporcionado ao ser humano a capacidade que o distingue dos outros animais: a habilidade de produzir cultura.

\subsubsection{Os sistemas sensoriais}

Somos capazes de perceber o mundo que nos rodeia através de nossos sistemas sensoriais. Em cada sistema sensorial, o contato com o mundo externo ocorre através de células especializadas chamadas de receptores sensoriais. Cada receptor é sensível a uma forma de energia física. Entretanto, todas as formas de energia dos estímulos são transformadas em energia elétrica. 0 processo pelo qual a energia do estímulo é transduzida se dá em dois estágios: a transdução do estímulo e a codificação neural.

O Sistema Auditivo é especializado na decodificação dos sons, converte as alterações na pressão do ar, associadas às ondas sonoras em atividade neural transmitida para o encéfalo. Essa tarefa é realizada em várias etapas que são 
muito bem descritas e estudadas pela neurofisiologia. (LENT, 2004; p. 243)

O som é uma criação do encéfalo e não existe sem ele. Quando uma mão bate em um tambor não produz nenhum som, a menos que alguém esteja lá para ouvi-lo. O ato de tocar um tambor simplesmente é capaz de produzir alterações na pressão atmosférica. Essas alterações na pressão assumem a forma de ondas, geradas por moléculas de ar que vibram.

A modalidade auditiva divide-se em algumas submodalidades: discriminação de intensidade sonora, discriminação tonal, identificação de timbres, localização espacial dos sons e compreensão da fala e sons complexos.

Além de detectar alterações muito pequenas na pressão atmosférica, o sistema auditivo também é muito habilidoso em perceber sons diferentes ao mesmo tempo. Enquanto você está fazendo uma atividade, é capaz de diferenciar outros tipos de sons a seu redor, como o trânsito na rua, pessoas conversando nas proximidades, passos no corredor, entre outros. Do mesmo modo, quando ouvimos música, é possível detectar os sons de diferentes instrumentos e vozes. Parece óbvio? Isto todo mundo sabe? Saber não sabe. Percebe e constata, o que é muito diferente! Você só pode perceber sons distintos simultaneamente, porque as diferentes freqüências de alteração na pressão atmosférica, associadas a cada som, estimulam os diferentes neurônios em seu sistema auditivo. É uma verdadeira façanha neurofisiológica que só pode ser realizada se houver neurônios ativados para essa função.

A percepção de sons é apenas o início de uma experiência auditiva. Para obter informações sobre os eventos em seu meio, o encéfalo interpreta os sons e analisa seus significados. Esses processos são ilustrados claramente no modo como se usa o som para se comunicar com outras pessoas, tanto pela linguagem 
como pela música.

A linguagem e a música diferem de outros impulsos auditivos de várias maneiras fundamentais. São sons que transmitem um significado especial. A análise do significado do som é mais complexa que a simples detecção de sua presença. Para analisar e produzir o significado dos sons e da fala, o encéfalo teve de desenvolver sistemas especiais localizados nos lobos temporais esquerdo e direito, respectivamente.

A linguagem oral e a habilidade musical não são apenas interligadas como sistemas complementares no encéfalo. Também são inter-relacionadas quanto ao conceito, pois ambas se baseiam no uso do som. Desse modo, para compreender como o ser humano se envolve em cada um desses comportamentos, examina-se primeiramente a natureza do som e como o ouvido humano e o sistema nervoso são estruturados para detectá-lo. Existem muitos artigos sobre essas questões publicados em revistas especializadas.

O Sistema Somatosensorial nos diz o que se passa com o nosso corpo, fornecendo informações sobre as sensações corporais. É formado por submodalidades, dentre as quais as principais são: o tato, que corresponde à percepção das características dos objetos que tocam a pele; a propriocepção, que consiste na capacidade de distinguir a posição estática e dinâmica do corpo e suas partes; a termossensibilidade, que permite perceber a temperatura dos objetos e do ar que nos envolve; a dor, que é a capacidade de identificar estímulos muito fortes, potenciais ou reais causadores de lesões em nossos tecidos. (KANDEL, 2003).

Este sistema contribui para que possamos compreender como nos posicionamos no mundo. Permite distinguir o que o mundo faz para nós do que nós fazemos para ele. Por exemplo, quando alguém lhe empurra para o lado, seu 
sistema somatosensorial the informa que você foi empurrado. Da mesma forma, caso você se jogue para o lado, seu sistema somatossensorial lhe informa que você fez o movimento. O fisiologista C.S. Sherrington (KANDEL, 2003), em 1890, descobriu a chamada sensibilidade proprioceptiva, que é fundamental para a nossa experiência do corpo. Quando caminhamos, corremos ou saltamos, estamos constantemente conscientes do que nosso corpo sente, e sabemos onde nos encontramos no espaço. A maior parte do tempo temos essa consciência sem perceber. Ao aprender uma nova habilidade, como andar de bicicleta, nadar, tocar um novo instrumento ou dirigir um carro também temos consciência de nossa sensibilidade proprioceptiva. Cada uma dessas habilidades exige um período de aprendizado e prática consciente. À medida que os movimentos necessários para andar de bicicleta ou tocar piano são dominados, eles são realizados cada vez mais inconscientes. Quando não precisamos mais pensar como tocar uma música ao piano, começamos realmente a produzir música verdadeiramente.

Para se ter uma idéia da extensão e importância das funções que esse sistema exerce, basta considerar o fato de que: se perdermos a visão, a audição ou ambas, ainda somos capazes de nos mover, entretanto, se perdêssemos a conexão com o sistema somotossenrorial, rapidamente os movimentos ficariam tão debilitados que poderiam inclusive comprometer a sobrevivência.

Entre os sistemas sensoriais este é o único que tem células receptoras distribuídas por todo o corpo, tanto na superfície da pele como também internamente nas camadas epiteliais. São os neurônios destes receptores que levam informações até a medula espinal. Nela, duas vias somatossensoriais se projetam até o encéfalo e, por fim, até o córtex somatossensorial.

A densidade dos receptores sensoriais varia muito nos diferentes locais 
do corpo, não apenas na pele, mas também nos músculos, tendões e articulações. As partes do corpo muito sensíveis ao tato ou capazes de movimentos refinados como as mãos, pés, lábios e olhos possuem muito mais receptores somatossensoriais.

Com estas informações, o entendimento do que é o tato, seu uso e suas possibilidades certamente se ampliam. Seria possível dançar, se movimentar ou saber onde e como você está sem a atuação deste sistema somatossensorial? A resposta é simples: não!

O Sistema Gustativo permite sentir o paladar e selecionar o alimento de acordo com o desejo e necessidades do próprio corpo. O paladar é principalmente uma função dos botões gustativos na boca, mas é sabido que o olfato contribui de forma significativa para a percepção gustativa. A experiência do paladar dada pela textura do alimento é detectada por receptores táteis da boca, assim como a presença de algumas substâncias no alimento, como a pimenta, estimulam as terminações de dor e condicionam muito a experiência do paladar.

Para análise prática do paladar, as propriedades dos receptores foram reunidas em quatro categorias gerais, denominadas sensações gustativas primárias. Elas são: ácido, salgado, doce e amargo. Alguns cientistas sugerem a existência de mais uma categoria de sabor, o umami, suscitado pelo glutamato. As centenas de sabores diferentes que podem ser percebidas são resultado de combinações das sensações elementares. O sabor amargo, quando ocorre em grande intensidade, faz geralmente com que o indivíduo rejeite o alimento. Essa reação é uma importante função objetiva da sensação do sabor amargo, porque várias toxinas mortais encontradas nas plantas venenosas são alcalóides, que causam sensação intensamente amarga. 
O forte elo entre gosto e prazer, ou talvez desprazer, é a base do fenômeno de aprendizado de aversão ou predileção a um gosto. Aprende-se rapidamente a evitar uma comida se sua ingestão causa, ou é associada, a disfunção gastrointestinal.

Quando o estímulo vem através do ar será decodificado pelo Sistema Olfativo. O olfato é talvez nosso sentido mais evocativo. É comum indivíduos considerarem esse sentido como secundário, mas essa não é a realidade, ele é essencial para a sobrevivência sendo a forma mais eficiente de comunicação e interpretação do meio circundante. Todos os cheiros ou odores que sentimos nos levam a uma experiência perceptual.

A vivência individual indica sempre uma relação entre um cheiro que sentimos e uma determinada substância emitida de perto ou a distância por uma fonte qualquer: uma flor, um animal, um alimento. O mecanismo neural responsável pela olfação é realizado por uma cadeia de neurônios que começa no nariz. As paredes internas do nariz são cobertas por uma mucosa, na qual estão incrustados os neurônios quimiorreceptores da olfação. Os sinais neurais serão então transmitidos ao bulbo olfatório, através de um sofisticado sistema de sinalização formado por circuitos neurais especializados.

Poucas pessoas são capazes de reconhecer sabores até familiares como: chocolate, café ou alho; sem a colaboração do olfato. A capacidade de sentir cheiros é muito maior que a capacidade de sentir sabores. Podemos detectar centenas de cheiros diferentes, e nossos antepassados tinham essa capacidade maior que a nossa, pois observa-se um grande número de pseudo-gens no sistema olfativo.

Todos os odores e gostos que reconhecemos são registrados no 
encéfalo com uma combinação de informações adicionais. Usualmente, o mais leve aroma é suficiente para resgatar vívidas memórias e evocar situações vivenciadas.

O Sistema Visual. A maioria de nossas impressões sobre o mundo e nossas memórias dele é baseada na visão. A informação visual domina nossas percepções e molda a maneira como pensamos. "Uma razão para o fato da visão ser tão importante é que ela nos torna capazes de perceber a informação a distância, encarregando-se do que é denominado de percepção exteroceptiva. Não necessitamos estar em contato imediato com o estímulo para processá-la" (GAZZANIGA, 2006; p.168).

O sistema visual analisa a luz. Essa energia eletromagnética pode vir diretamente de algo que a produz, com uma lâmpada ou o sol, ou indiretamente de uma fonte luminosa, após ser refletida por um ou mais objetos. Em qualquer um dos casos, a energia luminosa vem do mundo exterior, atravessa a pupila e entra no olho atingindo a retina. A partir da estimulação dos receptores na retina, começamos 0 processo de criação de um mundo visual.

De modo bastante sintetizado o processamento visual pode ser exemplificado da seguinte forma: Imagine que você está observando um quadrado laranja. O olho é apenas o primeiro componente deste sistema sensorial. No seu interior encontra-se a retina, composta de células fotorreceptoras (cones e bastonetes), onde se realizam os primeiros passos do processamento visual. A retina transmite a informação visual devidamente transduzida e codificada, através do nervo óptico e do núcleo geniculado lateral, para o córtex cerebral. No encéfalo tem então início o processamento que permitirá: 
- A detecção de bordas em V1 (córtex visual primário);

- Na Via Ventral: a visão das cores em V4, a discriminação das formas em IT (córtex temporal inferior);

- Na Via Dorsal: a detecção de movimentos em V5 ou MT (córtex temporal medial) e da localização espacial.

Esquema simbolizando as principais vias visuais.

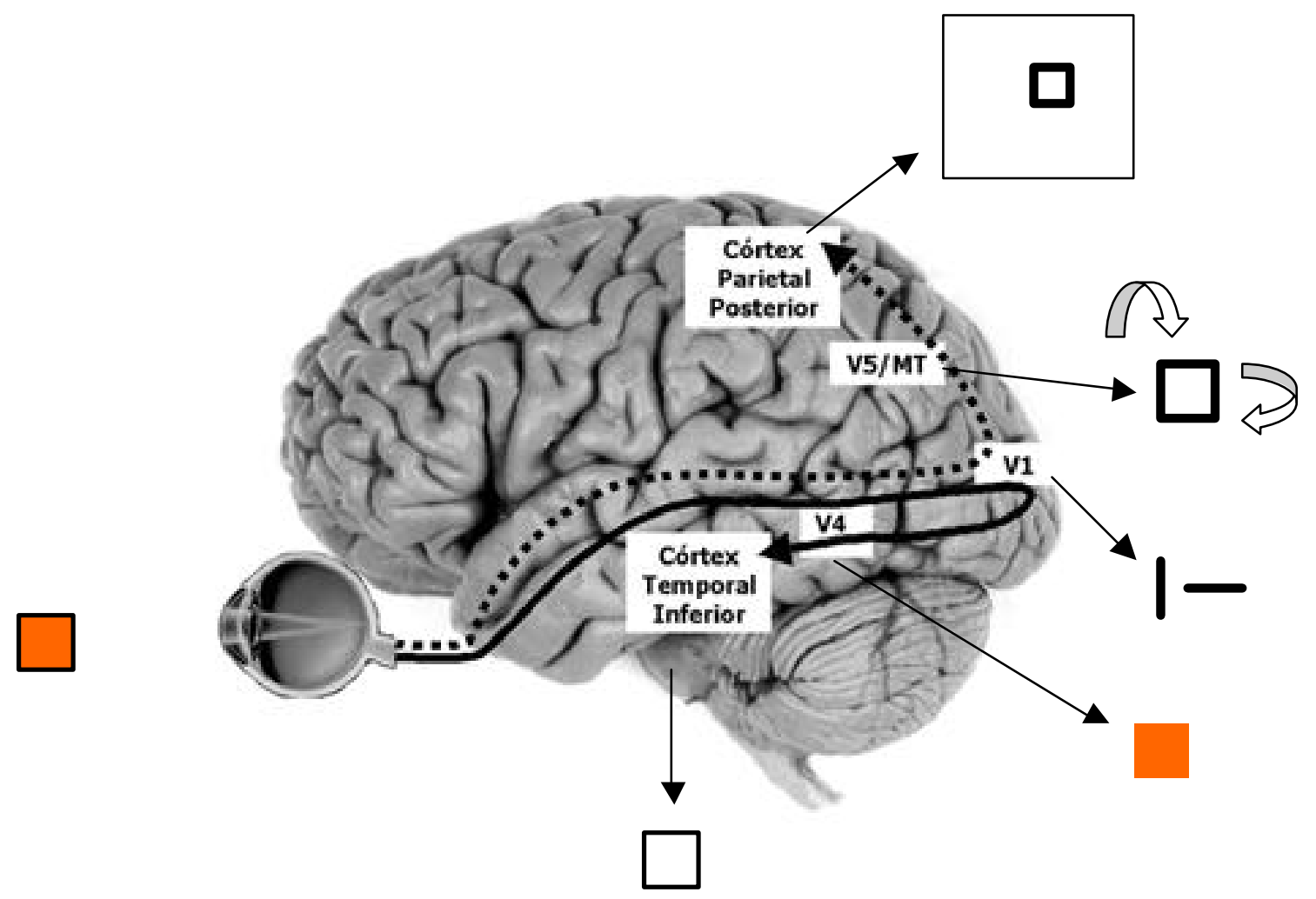

Para entender melhor a ilustração acima, na linha pontilhada representa-se a via dorsal (“onde”), responsável pela percepção de características tais como movimento e localização do objeto. Em linha contínua destaca-se a via ventral (“o quê"), envolvida no processamento de cor e forma. (KANDEL, 2000).

Embora experimentemos a percepção visual como um fenômeno consciente unificado, nossas percepções são construídas a partir de diversos componentes. Desses componentes, apenas alguns são acessíveis à experiência consciente. A experiência consciente parece estar associada ao processamento na 
via ventral. Isso significa que nos tornamos conscientes do formato e da cor do objeto como um resultado das operações neurais por meio das quais chegamos a reconhecer e a identificar o objeto visualizado. Por outro lado, o conhecimento que obtemos da via dorsal sobre como e onde segurar o objeto visualizado é inconsciente. Vários experimentos e pesquisas já demonstraram esse fato.

"Forma, movimento, profundidade e cor. Simplesmente olhar o mundo e reconhecer um rosto, ou apreciar uma paisagem requer uma atividade neuronal imensa, maior do que a utilizada para solucionar problemas lógicos ou jogar xadrez" (KANDEL, 2000, p. 492).

Ver cores não é apenas um prazer, é um recurso importante para aumentar a nossa percepção de detalhes e permitir-nos identificar melhor os objetos em meio a cenas visuais complexas. Nossa percepção das cores, formas e posição de objetos no espaço depende de inúmeros fatores, alguns deles celulares, outros ambientais, outros ainda de natureza cultural.

Os sistemas sensoriais foram pincelados acima isoladamente para facilitar a compreensão e mostrar a extensão e importância de cada um. Mas, o funcionamento é simultâneo e nenhum deles continuaria existindo se não houvesse uma utilidade e uma função ativa no organismo. Iván Izquierdo, neurocientista pesquisador da memória, na PUC/RS, realça, constantemente em suas palestras, o fato de que "Não há dúvida de que a função faz o órgão". A natureza naturalmente vai suprimindo e substituindo o que não é útil em um organismo.

Durante a maior parte de nossa existência não nos damos conta de nosso corpo. Muita coisa acontece com ele minuto a minuto, mas só as mais significativas são registradas pela consciência. Embora, geralmente tenhamos a impressão de estar no controle de todos os pensamentos e comportamentos, 
exercendo como senhores absolutos o controle de nossa vontade.

No entanto, embora a consciência não se dê conta de tudo, o sistema nervoso recebe e processa continuamente todas as informações sobre a posição e o movimento das partes do corpo e do corpo como um todo, sobre o estado de nossas vísceras, sobre a textura, a forma e a temperatura dos objetos que tocamos e sobre a integridade de nossos tecidos. Essas informações são selecionadas, filtradas e encaminhadas a diferentes regiões neurais, que as vão utilizar de diversas maneiras. A parte que atingirá a consciência servirá para orientar o comportamento e o raciocínio, podendo ser armazenada na memória para utilização posterior. A parte inconsciente servirá para coordenar nossos movimentos de modo a manter a postura e o equilíbrio corporal, e para ajustar o funcionamento dos órgãos e das vísceras de acordo com as necessidades fisiológicas.

$\mathrm{O}$ ato de perceber e construir um repertório mnemônico fornece ao indivíduo o certificado de posse do conhecimento adquirido. Afinal, ninguém pode construir perceptos por você! Esta é uma atividade pessoal, única e intransferível. Os seus perceptos são construídos a partir da atividade neuronal gerada em determinadas áreas de seu encéfalo, quando sua atenção é dirigida ao objeto de sua observação. A possibilidade de registrar o resultado desta experiência envolve o acionamento dos mecanismos relacionados à formação de diferentes tipos de memória. A formação de um representativo repertório mnemônico propicia ao indivíduo maior variabilidade, flexibilidade e adaptabilidade na formulação de suas ações no mundo.

A maior parte daquilo que sabemos sobre o mundo não foi construída em nosso encéfalo ao nascer, mas foi adquirida por meio da experiência e mantida pela memória - o nome e o rosto de nossos amigos e das pessoas que amamos, álgebra e geografia, 
política e esportes, assim como a música de Haydn, Mozart e Beethoven. Como resultado, somos quem somos em grande parte porque aprendemos e lembramos. A memória, porém, não é apenas um registro de experiências pessoais: ela permite que recebamos instrução e é uma poderosa força para o progresso social (KANDEL, 2003; p. 14).

Para se ter uma idéia da beleza dos sistemas funcionando integrados, processando em milissegundos uma quantidade fantástica de informações, imagine apenas um momento do seu dia, uma pequena cena, talvez rotineira do seu cotidiano. Imagine que você está tomando um cafezinho. Na cena rememorada relacione a atividade neural necessária para que você possa identificar os elementos fornecidos pela visão (a forma da xícara, a cor do café e da xícara, o movimento da mão em relação à xícara e do líquido dentro da xícara, a localização da xícara na mesa); pela audição (som, timbre e tons), pela somestesia (tato, propriocepção, dor e termosensibilidade); pelo gosto advindo do paladar (doce e amargo) e pelos cheiros, os aromas vindos vívidos da memória evocada desta cena escolhida.

Imagine tudo isso acontecendo simultaneamente, seguidamente em todas as horas do dia. São bilhões de neurônios em atividade constante. Propiciando a manifestação da sua vida.

Se a manifestação da vida já é bela em si, o que se poderia dizer da vida manifestada com arte? Bons artistas deixam suas marcas ao longo da história, que permanecem justamente por traduzirem um conhecimento útil para o homem e para humanidade.

O sabor de uma madeleine mergulhada no chá é uma das mais famosa evocações da experiência sensitiva na literatura. A descrição de Proust sobre a 
natureza consciente da sensação e da memória permite profundos vislumbres sobre o tema abordado. O texto abaixo foi escolhido por Eric Kandel, neurobiologista da Columbia University, para ilustrar, em seu livro "Princípios da Neurociência", as sensações expressas por uma pessoa.

[...] um dia no inverno, quando eu voltava para casa, minha mãe, vendo que eu estava com frio, ofereceu-me chá, algo que eu normalmente não bebia. No começo eu resisti e então, sem nenhuma razão particular, mudei de idéia. Ela serviu um desses bolinhos rechonchudos chamados "madeleines", que parecem ter sido moldados numa concha de crustáceo. Então, mecanicamente, desanimado após um dia melancólico e com a perspectiva de um amanhã monótono, encostei meus lábios numa colherada do chá no qual eu tinha mergulhado um pedaço de bolinho. Tão logo aquele líquido quente misturado com pedacinhos do bolinho tocou meu palato, senti um calafrio e parei para entender o que estava acontecendo comigo. Um prazer indescritível invadiu meus sentidos. Um prazer isolado, destacado, sem alusão da sua origem. De uma só vez as vicissitudes da vida se tornaram indiferentes para mim, seus desastres inócuos, sua brevidade ilusória _ esta nova sensação teve em mim um efeito de preenchimento equivalente ao do amor e de sua preciosa essência; ou melhor, esta essência não estava em mim, ela agora era eu (PROUST, apud: KANDEL, 2003, p. 407).

O artista gráfico holandês, Mauritius Cornelius Escher (1898-1971), colocou a percepção como tema central de suas obras. As cenas que ele elaborou nunca poderiam existir senão na dimensão das imagens artísticas, levando o espectador a se equilibrar constantemente nos limites do que seria a realidade, a ilusão e ativando vividamente sua imaginação. 
Segundo o médico e físico alemão Hermann von Helmholtz (18211894), nossa percepção é construída por meio de inferências que inconscientemente fazemos sobre o mundo à nossa volta. Essas inferências são contrastadas com informações que o organismo colhe do ambiente. Cada vez que essas expectativas não são correspondidas, ajustamos nossos perceptos, criando novas inferências e testando novas conjecturas (BALDO, 2003).

Escher desafia o espectador a realizar essas inferências em todas as suas obras, sempre se renovando, evitando a mesmice e a monotonia.

A Arte como forma de linguagem visual nos comunica um conteúdo, mas não ao nível apenas anedótico ou ilustrativo, reproduzindo algum objeto ou episódio incidental. Seu conteúdo é bem mais profundo. Por isso nos comove e instiga nossa formulação dos conceitos apresentados de forma pictórica. A apreciação das gravuras de Escher é capaz de ampliar e instigar a capacidade perceptiva do espectador.

No universo de Escher, o que sobe desce, o que está dentro está fora e o modelo pode ser a própria representação. Os efeitos gráficos são conseguidos com uma técnica primorosa e o uso da perspectiva, sugerindo uma representação subvertida. Enfim, Escher traduz visualmente, em sua obra, o resultado de suas introspecções relacionadas ao significado da percepção.

Na gravura ao lado, "Mão segurando um espelho esférico" de 1934, Escher compõem um auto-retrato em que tanto se auto percebe, como ao mesmo tempo mostra ao espectador suas percepções. Com uma síntese visual demonstra seu entendimento sobre o que é a percepção. 
Ao observar a obra temos mais informação do ambiente circundante do que se estivéssemos sentados no próprio ambiente.

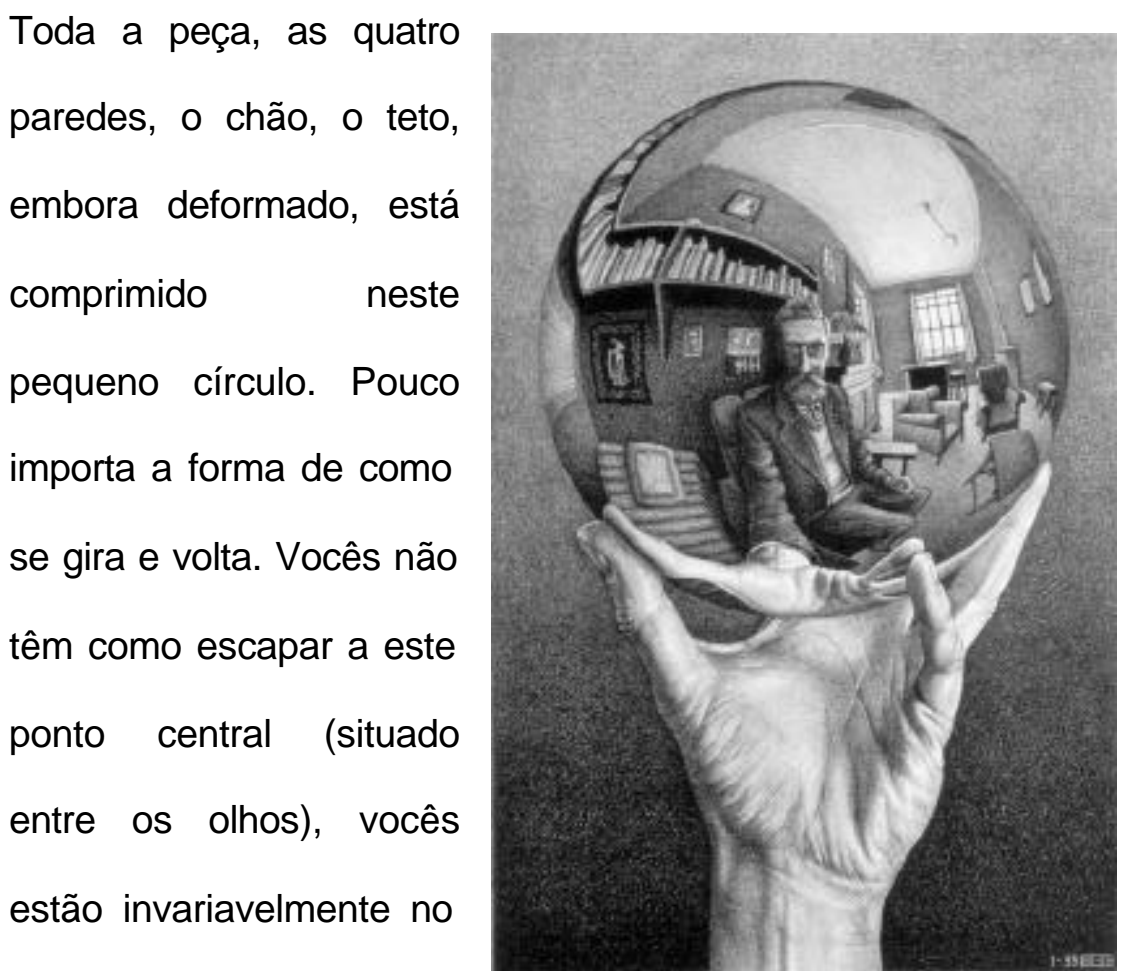

Centro de vosso Universo. (ESCHER, apud: ACILLOTTI, 2004)

Ações no mundo, transformando o

entorno, deixam uma assinatura. A assinatura do indivíduo começa na base bioquímica de suas

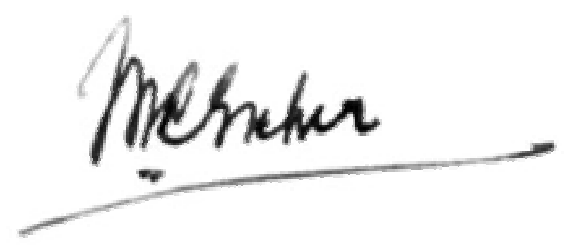
memórias e termina no registro gráfico-gestual de seu nome. É a assinatura de sua obra!

O influente escultor francês, Auguste Rodin (1840-1917) registra suas percepções em suas obras utilizando todos os sistemas sensoriais, porém quando consideramos uma expressão tridimensional, é importante salientar a atuação do sistema somatossensorial. Afinal, realizando ou apreciando uma escultura precisamos movimentar-nos fisicamente ao redor dela para que possamos perceber suas formas. A sensação de uma forma escultural não é decifrada apenas por 
intermédio da visão, mas principalmente pelo toque da mão deslizando sobre ela. Rodin considerava que a escultura tinha de ser feita de dentro para fora. Ele fazia vários desenhos de suas obras antes de modelá-los em argila, a fim de, segundo ele, testar até que ponto suas mãos já sentiam o que seus olhos viam. Certa vez comentou:

Para o meu trabalho de modelagem tenho de possuir não só o total conhecimento da forma humana, mas também uma profunda percepção em relação a todos os seus aspectos. Tenho, por assim dizer, de incorporar as linhas do corpo humano e elas precisam tornar-se parte de mim mesmo... Somente então posso ter certeza de que estou compreendendo (RODIN, apud: ROOT-BERNSTEIN, 2001, p. 167).

O corpo em movimento era o meio de Rodin expressar emoção. Ele sempre buscou expressar os sentimentos internos através da mobilidade dos músculos. Existe um fato que reflete bem o seu modo de trabalhar: certa vez, durante um ataque de raiva, sua esposa entrou no atelier e pôs-se a andar pela sala aos gritos. Podin fez o molde de seu rosto enraivecido, sem olhar para o barro. "Obrigado, minha querida", ele disse no final do episódio. "Foi excelente."

Se tomarmos como exemplo sua obra $O$ pensador, uma das esculturas mais conhecidas no mundo. Abaixo ela é mostrada em vários ângulos.
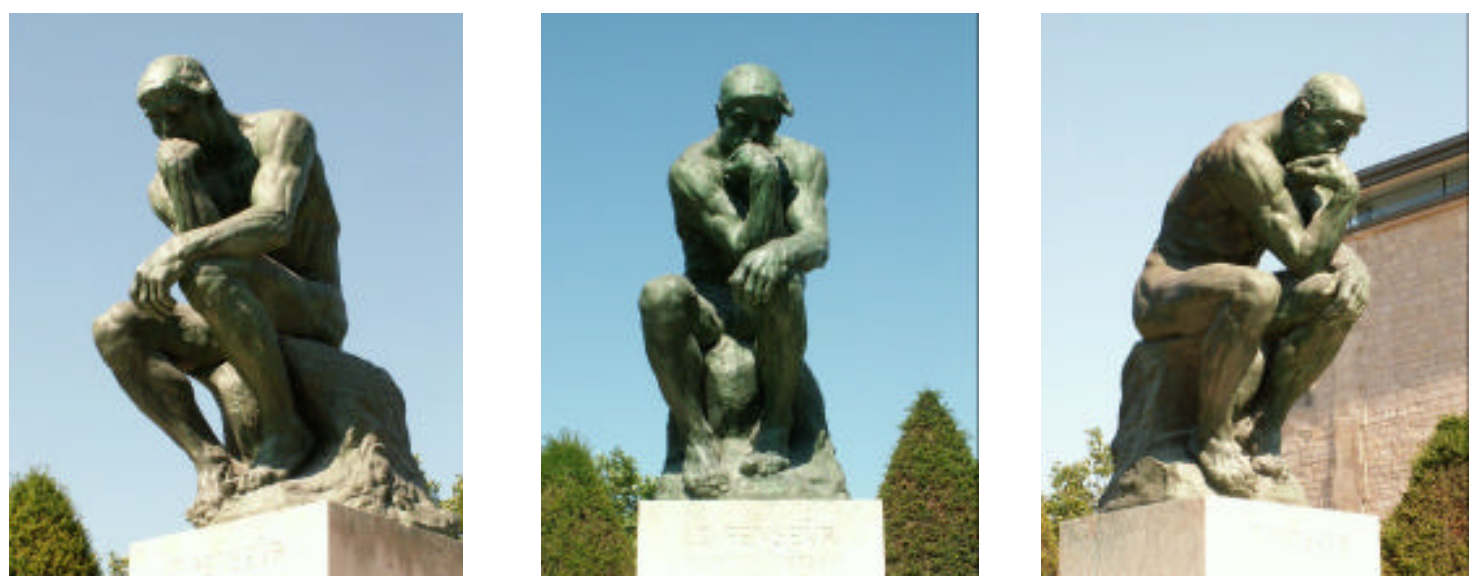
Um homem nu, que Rodin pretendia fosse o representante de todos os poetas, todos os artistas, todos os inventores, está sentado sobre uma pedra em atitude de tensa e intensa contemplação. Rodin escreveu: "O que faz meu pensador pensar é o fato de que ele pensa não só com o cérebro, com o cenho franzido, as narinas dilatadas e lábios comprimidos, mas com cada músculo de seus braços, costas e pernas, com o punho cerrado e dedos dos pés retesados." (RODIN, apud: ROOT-BERNSTEIN, 2001, p.167).

O espectador pode experimentar essas sensações ao apreciar a obra, ou até mesmo imitando a postura do Pensador. Por exemplo, observe a figura do Pensador acima. Agora, sem olhar mais para a ilustração, posicione o seu corpo imitando da melhor forma a postura do Pensador. Por um instante mantenha a posição do Pensador, feche os olhos e procure perceber seu corpo por dentro. Retorne a imagem e certamente você notará que posicionou braços, mãos, pernas e pés de maneira ligeiramente incorreta. Para conseguir imitar o Pensador, será necessário não apenas imitar a posição correta, mas também o tensionamento correspondente dos músculos. Ao procurar imitar o Pensador de Rodin, você vivenciou uma experiência proprioceptiva.

Músicas, melodias, danças, esculturas, pinturas, poemas, realizadas em todos os períodos da história da arte, traduzem uma época, foram geradas com o funcionamento dos sistemas sensoriais e expressam sua mensagem também com o acionamento dos sistemas sensoriais de quem as observa e com essas interage.

Por que será que duas pessoas não percebem do mesmo modo uma música ou um quadro? O que leva a pessoa a não perceber igualmente a mesma música se a ouvir em momentos diferentes? Fisiologicamente há duas razões para isso. Primeiro, as capacidades sensoriais dos neurônios auditivos são ligeiramente 
diferentes nos indivíduos, tanto pelo genoma distinto, como por diferentes experiências e influências ambientais. Segundo, o mesmo indivíduo atravessa diversos estados fisiológicos e psicológicos ao longo do dia e da vida, e esses estados de consciência, estados emocionais, saúde, doença são capazes de modificar as informações que os sentidos veiculam, provocando percepções diferentes.

O outro componente é o aprendizado pessoal que cada indivíduo constrói ao longo da vida. O produto da percepção está intimamente ligado com a memória e o aprendizado que serão os temas abordados do próximo capítulo.

\subsection{Memória e aprendizado}

Nossas memórias registram nossas vidas. Quando uma pessoa perde sua memória, ela não perde sua vida, mas sim as anotações de seus registros, dos fatos memorizados e anteriormente ordenados. Com as memórias de uma vida escreve-se uma biografia. Por exemplo:

Guimarães Rosa, sua consagração definitiva viria com o romance Grande sertão veredas. Eleito para a Academia Brasileira de Letras em 1963, só tomaria posse em 1967... ou... João Guimarães Rosa (1908-1967) nasceu em Cordisburgo (MG). Formado em Medicina, exerceu a profissão até 1934, quando ingressou na carreira diplomática, tendo servido na Alemanha, Colômbia e França... ou... Joãozito, como era chamado, com menos de sete anos começou a estudar francês sozinho, por conta própria. Somente com a chegada do Frei Canísio Zoetmulder, frade franciscano holandês, em março de 1917, pode iniciar-se no holandês e prosseguir os estudos de francês, agora sob a supervisão daquele 
frade... no curso ginasial matricula-se no Colégio Arnaldo, de padres alemães e, imediatamente, iniciou o estudo do alemão, que aprendeu em pouco tempo. Era um poliglota, conforme um dia disse a uma prima, estudante, que fora entrevistá-lo:

Falo: português, alemão, francês, inglês, espanhol, italiano, esperanto, um pouco de russo; leio: sueco, holandês, latim e grego (mas com o dicionário agarrado); entendo alguns dialetos alemães; estudei a gramática: do húngaro, do árabe, do sânscrito, do lituânio, do polonês, do tupi, do hebraico, do japonês, do tcheco, do finlandês, do dinamarquês; bisbilhotei um pouco a respeito de outras. Mas tudo mal. E acho que estudar o espírito e o mecanismo de outras línguas ajuda muito à compreensão mais profunda do idioma nacional. Principalmente, porém, estudando-se por divertimento, gosto e distração. (RELEITURAS, GUIMARÃES ROSA - BIOGRAFIA)

Ao estudar, aprender, colecionar fatos e acontecimentos, armazenar e elaborar cultura, estamos ativando o encéfalo. O encéfalo trabalha incessantemente enquanto aprendemos e armazenamos nossas memórias.

$\mathrm{E}$, onde estarão as memórias? Certamente vamos encontrá-las passeando pelos pensamentos e brincando com a imaginação. Mário Quintana, com seu humor característico, dizia que "imaginação é a memória que enloqueceu". E, Guimarães Rosa, sem falar da memória diretamente, em dois parágrafos resume, de modo único, o tema deste capítulo.

Contar é muito dificultoso. Não pelos anos que já se passaram. Mas pela astúcia que tem certas coisas passadas de fazer balancê, de se remexerem dos lugares. A lembrança da vida da gente se guarda em trechos diversos: uns com os outros acho que nem não misturam. Contar seguido, alinhavado, só mesmo sendo coisas de rasa importância. Assim é que eu acho, assim é que eu conto. O senhor 
foi bondoso de me ouvir. Tem horas antigas que ficaram muito mais perto da gente do que outras de recente data. O senhor mesmo sabe; e se sabe, me entende. Toda saudade é uma espécie de velhice (ROSA, apud: MACHADO, 1989, p. 78).

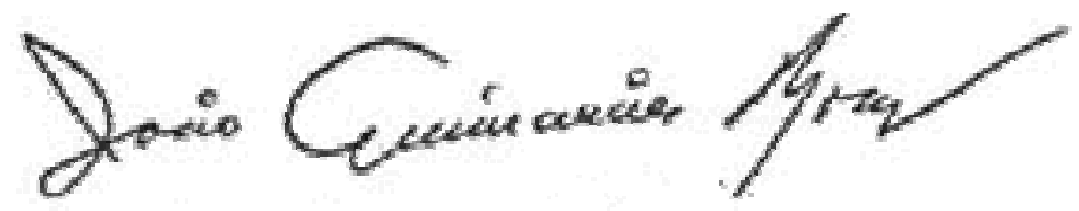

Existem muitas maneiras de aprender, podemos aprender observando, pensando, repetindo até a exaustão, brincando e inclusive estudando. O que fica na memória é o que nós aprendemos, mas nem tudo que aprendemos ficou na memória! Embora a memória seja um fator essencial para a consciência de si mesmo, ela é simultaneamente repleta de mistérios.

O lingüista Noan Chomsky declarou, certa vez, que nossa ignorância pode ser dividida em problemas e mistérios. Certamente a memória, também pode ser dividida em problemas e mistérios. Quando nos defrontamos com um mistério, ficamos entre maravilhados e perplexos, sem ao menos uma idéia de como seria a explicação. Porém, quando estamos diante de um problema, podemos não saber a solução, mas temos insights, acumulamos um conhecimento crescente sobre ele e temos uma vaga idéia do que buscamos.

Os cientistas transformam os mistérios da memória em problemas a serem investigados. E de pergunta em pergunta, de experimento em experimento, (experimentos os mais diversos utilizando ratos; aplysia, a lesma marinha; drosophila, a mosca-das-frutas; beija-flor; pombos; macacos e humanos) formaram uma teoria a respeito do funcionamento da memória e do aprendizado.

Esses estudos (de como ocorre o aprendizado e de como as memórias são armazenadas) iniciam-se com a filosofia, depois a psicologia, a seguir a biologia 
e continua com a neurociência. Portanto, o estudo científico da memória e do aprendizado é uma longa história.

Muitos comportamentos importantes são aprendidos. Na verdade, nós somos quem somos, em grande parte, devido ao que aprendemos, a forma como aprendemos e ao que lembramos. Assim, aprendizagem e memória são o suporte para todo o nosso conhecimento, habilidades e planejamento. Com o repertório mnemônico formamos um banco de dados para que possamos considerar o passado, nos situarmos no presente e prevermos o futuro.

A análise de como ocorre o aprendizado e de como são armazenadas as memórias no encéfalo, tem motivado várias pesquisas na área: da biologia, da psicologia e da neurociência. Segundo Kandel, "A memória promete ser a primeira das faculdades mentais a ser compreensível em uma linguagem que estabeleça uma ponte entre as moléculas e a mente, ou seja, das moléculas às células, e daí, aos sistemas encefálicos e ao comportamento". (KANDEL, 2003 p.15).

Qual a relação entre aprendizado e memória? O aprendizado é o processo através do qual nós adquirimos o conhecimento sobre o mundo, enquanto a memória é o processo pelo qual o conhecimento é codificado, retido e, posteriormente recuperado.

O aprendizado e a memória podem ser subdivididos, hipoteticamente, nos principais estágios: codificação, armazenamento e evocação.

A codificação refere-se ao processamento da nova informação a ser armazenada. A codificação envolve duas fases: aquisição e consolidação. A aquisição registra as informações em arquivos sensoriais e estágios de análise sensorial, enquanto a consolidação cria uma forte representação da informação através do tempo. 0 armazenamento, resultado da aquisição e da consolidação, cria e 
mantém um registro permanente. Finalmente, a evocação utiliza a informação armazenada para criar uma representação consciente ou executar um comportamento aprendido com um ato motor (GAZZANIGA, 2006, p. 320).

Como a memória possui um componente temporal, faz sentido categorizá-la segundo o tempo pelo qual armazenamos uma informação. Uma classificação habitual é, de acordo com o tempo transcorrido entre sua aquisição e o momento em que são evocadas:

- a memória utra-rápida (ou imediata), cuja retenção não dura mais que alguns segundos (segundos, minutos);

- a memória de curto prazo (ou curta duração), que dura minutos ou horas e serve para proporcionar a continuidade do nosso sentido do presente (horas ou poucos dias);

- a memória de longo prazo (ou de longa duração), que estabelece engramas ${ }^{16}$ ou traços duradouros (dura dias, semanas, meses, ou mesmo anos).

Roberto Lent coloca um exemplo da cena cotidiana que ilustra muito bem essa classificação da memória:

Você se dirige à sala de aula para realizar uma prova difícil. No caminho, alguém te intercepta e pergunta quais assuntos cairão na prova. Você começa a responder, e precisa reter por alguns segundos a primeira palavra para emitir a segunda com coerência; a seguir, precisa reter a segunda para emitir a terceira, e assim por diante. Você utilizou a sua memória ultra-rápida: se alguém lhe

16 Engrama é o somatório total das alterações no encéfalo que codificaram inicialmente uma experiência e que então constituem o registro daquela experiência. 
perguntar logo depois quais são exatamente as palavras que pronunciou ao responder sobre os temas da prova, não se lembrará. Ao chegar à sala de aula, um colega lhe pergunta se foi homem ou mulher a pessoa que a interceptou no caminho. Você responderá corretamente utilizando a sua memória de curta duração, e se concentrará na prova. Alguns dias depois, tudo que restará em sua memória daquele dia na universidade provavelmente será a prova, ou talvez apenas as questões mais difíceis dela, que foram armazenadas na sua memória de longa duração. (LENT, 2004, p. 593).

Também é possível classificar as memórias de acordo com o tipo de informação: declarativa ("saber que") e de procedimentos ("saber como"); ou semântica (a linguagem, ou outros códigos) e episódica (memória de eventos ou episódios).

A primeira vista, ao tomar conhecimento da classificação citada acima, poderíamos pensar que esta é uma tarefa fácil ou apenas descritiva. Mas, além dos limites entre um tipo de memória e outro nem sempre serem definidos, também é preciso demonstrar como um organismo armazena suas memórias nas células.

Iván Izquierdo, neurocientista que estuda a memória, na PUC/RGS, descreve claramente essa questão:

Apesar de algumas tentativas iniciais, nunca foi realmente possível distinguir claramente entre estes tipos de memória. Uma memória declarativa (sabemos que pôr os dedos na tomada é perigoso) se converte, pela repetição, numa memória de procedimentos (automaticamente, sabemos como não colocar os dedos nas tomadas), ou num hábito. Um conhecimento semântico — o inglês é adquirido em forma episódica (através de aulas) e pode ser evocado em forma episódica ou não. Por outro lado, não há evidência consistente de que os diversos tipos de memória correspondam a representações neuronais diferentes (IZQUIERDO, 2002). 
Tipos e características da memória

\begin{tabular}{|c|c|c|}
\hline \multirow{4}{*}{ 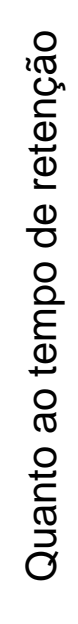 } & Tipos e subtipos & Características \\
\hline & Ultra-rápida & $\begin{array}{l}\text { Dura de frações de segundos a alguns } \\
\text { segundos; memória sensorial. }\end{array}$ \\
\hline & Curta duração & $\begin{array}{l}\text { Dura minutos ou horas, garante o sentido de } \\
\text { continuidade do presente. }\end{array}$ \\
\hline & Longa Duração & $\begin{array}{l}\text { Dura horas, dias ou anos, garante o registro } \\
\text { do passado autobiográfico e dos } \\
\text { conhecimentos do indivíduo. }\end{array}$ \\
\hline \multirow{9}{*}{ 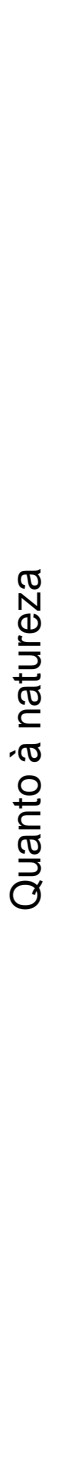 } & Explícita ou declarada & Pode ser descrita por meio de palavras. \\
\hline & Episódica & $\begin{array}{l}\text { Tem uma referência temporal; memória de } \\
\text { fatos seqüenciados. }\end{array}$ \\
\hline & Semântica & $\begin{array}{l}\text { Envolve conceitos atemporais; memória } \\
\text { cultural. }\end{array}$ \\
\hline & $\begin{array}{l}\text { Implícita ou não- } \\
\text { declarativa }\end{array}$ & Não pode ser descrita por meio de palavras. \\
\hline & $\begin{array}{l}\text { De representação } \\
\text { percentual }\end{array}$ & $\begin{array}{l}\text { Representa imagens sem significado } \\
\text { conhecido; memória pré-consciente. }\end{array}$ \\
\hline & De procedimentos & Hábitos, habilidades e regras. \\
\hline & Associativa & $\begin{array}{l}\text { Associa } 2 \text { ou mais estímulos } \\
\text { (condicionamento clássico), ou um estímulo a } \\
\text { uma certa resposta (condicionamento } \\
\text { operante). }\end{array}$ \\
\hline & Não associativa & $\begin{array}{l}\text { Atenua uma resposta (habituação) ou a } \\
\text { aumenta (sensibilização) através da repetição } \\
\text { de um mesmo estímulo. }\end{array}$ \\
\hline & Operacional & $\begin{array}{l}\text { Permite o raciocínio e o planejamento do } \\
\text { comportamento. }\end{array}$ \\
\hline
\end{tabular}

Fonte: Lent, 2004, p. 593. 
Nossa habilidade de lembrar eventos não se reflete na operação de um único sistema de memória, mas em uma combinação de, no mínimo, duas estratégias usadas pelo encéfalo para adquirir informação. Uma das estratégias é denominada de memória declarativa (ou memória explícita), requerendo participação consciente e envolvendo o hipocampo e o lobo temporal. A outra é a memória não-declarativa (ou memória implícita), a qual não requer participação consciente, utilizando estruturas não corticais.

Memória declarativa (ou explícita) Para que possamos reconhecer esse tipo de memória em nossa realidade diária, Kandel (2003, p. 81), em seu livro Memória: da mente às moléculas, sugeriu que se faça o seguinte exercício:

- Por um momento, tente recordar o nome de um amigo, talvez um colega de escola ou faculdade;

- A seguir, lembre-se de um determinado episódio que envolva esse amigo - uma conversa importante, um evento significativo, talvez uma viagem especial;

- Recrie o episódio em sua imaginação, movendo-se mentalmente ao tempo e ao lugar onde ele ocorreu.

Uma vez que o contexto tenha sido reconstruído, pode parecer surpreendente a facilidade com que você recorda a cena e aquilo que ocorreu. Assim, uma pessoa pode mergulhar em uma série de recordações, algumas vezes acompanhadas por fortes emoções e por uma noção irresistível de familiaridade pessoal com aquilo que está sendo evocado. É interessante que, ao realizar um exercício de evocação como essa, uma pessoa não depende de qualquer capacidade retrospectiva bem desenvolvida, nem precisa de treinamento ou instruções. Lembranças vívidas do passado são coisas que todos possuímos e podemos lembrar diariamente, sem esforço (KANDEL, 2003, p. 81). 
A memória declarativa é a memória para eventos, fatos, palavras, face, música - todos os vários fragmentos do conhecimento que fomos adquirindo durante uma vida de experiência e aprendizado, conhecimento que pode potencialmente ser declarado, ou seja, trazido à mente de uma forma verbal ou como uma imagem mental. A memória declarativa é também denominada memória explícita ou memória consciente.

Quando falamos em trazer à mente um evento passado, seja lembrança de um amigo ou um pensamento passageiro sobre um evento ocorrido anteriormente neste mesmo dia, estamos falando da memória em seu sentido mais comum, que nos é o mais familiar. Estamos falando da memória como uma recordação consciente, assim também será necessário um esforço consciente para recordá-la, ou seja, percebemos estar acessando as informações armazenadas. A memória declarativa está sub-caracterizada em:

- Episódica (a memória para determinados tempos e lugares). A memória episódica está envolvida a eventos datados, isto é, relacionados ao tempo. Usamos a memória episódica, por exemplo, quando lembramos da festa de aniversário de 15 anos.

- Semântica (a memória para os fatos). Abrange a memória utilizada para descrever o conhecimento organizado do mundo. Na evocação desse tipo de informação não precisamos lembrar de qualquer evento passado em particular. Basta saber que certos objetos são familiares ou que certas associações entre as características do objeto estão corretas. Assim, a memória semântica envolve conceitos atemporais. Usamos a memória semântica ao aprender 
que Brasília é a capital do Brasil, ou que os neurônios se comunicam por meio de neurotransmissores.

Nós usamos a memória episódica quando nos lembramos que vimos ontem as primeiras flores da primavera ou que ouvimos a Sonata ao Luar, de Beethoven, vários meses atrás. Nós usamos a memória semântica para guardar e lembrar de conhecimentos objetivos, o tipo de conhecimento que aprendemos na escola e nos livros. No entanto, todas as memórias explícitas podem ser concisamente expressas em afirmações declarativas, tais como No verão passado visitei minha avó em sua casa de campo (conhecimento episódico) ou $\mathrm{O}$ cobre é mais pesado que a água (conhecimento semântico) (KANDEL, 2000 p. 1231).

A organização e a flexibilidade do conhecimento semântico são surpreendentes. Consideremos uma imagem visual complexa, como a fotografia de um cavalo. Através da experiência, essa imagem visual torna-se associada a outras formas de conhecimento sobre cavalos, de tal forma que, enfim, quando fechamos nossos olhos e pensamos sobre a imagem de um cavalo, a imagem é baseada em uma representação rica do conceito de um cavalo. Quanto mais associações tivermos feito sobre a imagem de um cavalo, melhor nós codificamos tal imagem e melhor ainda poderemos nos recordar das características de um cavalo no futuro.

Além disso, tais associações caem em diferentes categorias. Por exemplo, sabemos que um cavalo é um ser vivo, em vez de inanimado, que é um animal e não uma planta, que vive em um ambiente particular e que tem características físicas e padrões de comportamento particulares e emite um repertório de sons. Além disso, sabemos que os cavalos são usados para realizar certas tarefas e que eles têm nomes específicos. A palavra cavalo é associada a 
todos esses pedaços de informações e qualquer um desses pedaços pode abrir o acesso a todo o nosso conhecimento sobre cavalos. Como esse exemplo ilustra, "nós construímos o conhecimento semântico através de associações feitas ao longo do tempo. A capacidade de recordarmos e utilizarmos esse conhecimento - nossa eficácia cognitiva - parece depender de quão bem essas associações organizaram as informações que retivemos."(KANDEL, 2000, p. 1235).

Memória não-declarativa (ou implícita) - Não precisa ser verbalizada (declarada). Essa memória é recordada inconscientemente e fortemente conectada às condições de estímulo originais sob as quais a aprendizagem ocorreu. Kandel descreve vários procedimentos que realizamos diariamente, de forma automatizada e inconsciente, por isso mesmo não nos damos conta, repare,

[...] quando somos apresentados a um visitante, estendemos a nossa mão para um cumprimento. Podemos olhar para o céu em um dia nublado e ter alguma idéia sobre a probabilidade de chuva. Quando lemos, como adultos, executamos habilidades complexas de movimentos oculares e de compreensão de texto que foram aperfeiçoadas durante milhares de horas de prática. Quão confiável ou precisamente fazemos tais coisas depende de nossa experiência passada e das oportunidades que tivemos para nos instruirmos e praticarmos. Mas aprendemos de fato, e chegamos a desempenhar essa e incontáveis outras tarefas sem perceber que estamos utilizando a memória (KANDEL, 2003, p. 191)

Essa é a memória utilizada para procedimentos e habilidades reflexas motoras ou perceptuais. Por exemplo, a habilidade para dirigir, jogar bola, dar um nó no cordão do sapato, nadar, etc. Apresenta quatro subtipos:

- memória adquirida e evocada por meio de "dicas" (Priming) ou memória de representação perceptual - que corresponde à imagem de um evento, preliminar à compreensão do que ele 
significa. Um objeto, por exemplo, pode ser retido nesse tipo de memória implícita antes que saibamos o que é, para que serve, etc. Considera-se que a memória pode ser evocada por meio de "pistas" (fragmentos de uma imagem, a primeira palavra de uma poesia, certos gestos, odores ou sons).

- memória de procedimentos - refere-se às habilidades e hábitos. Conhecemos os movimentos necessários para andar de bicicleta, nadar, dirigir um carro, sem que seja preciso descrevê-lo verbalmente.

- memória associativa - associa dois ou mais estímulos (condicionamento clássico), ou um estímulo a uma certa resposta (condicionamento operante).

- memória não-associativa - está estritamente relacionada a algum tipo de resposta ou comportamento. Empregamos a memória associativa, por exemplo, quando começamos a salivar pelo simples fato de olhar para um alimento apetitoso, por termos, em algum momento de nossa vida associado seu aspecto ou cheiro à alimentação. Por outro lado, usamos a memória não associativa quando, sem nos darmos conta, aprendemos que um estímulo repetitivo, por exemplo, o barulho dos pingos da chuva não traz riscos, o que nos faz relaxar e ignorá-lo.

A memória de operacional ${ }^{17}$ é crucial tanto no momento da aquisição como no momento da evocação de toda e qualquer memória, declarativa ou não. Através dela armazenamos temporariamente informações que serão úteis apenas

\footnotetext{
${ }^{17}$ Muitos especialistas consideram memória de curta duração e memória operacional como sendo a mesma.
} 
para o raciocínio imediato e a resolução de problemas, manter uma conversação ou para a elaboração de comportamentos, podendo ser esquecidas logo a seguir. Em outras palavras, ela mantém a informação viva durante poucos segundos ou minutos, enquanto ela está sendo percebida ou processada. Armazenamos em nossa memória de curta duração, por exemplo, o local onde estacionamos o automóvel, uma informação que será necessária até o momento de chegarmos até o carro $^{18}$.

\subsubsection{Plasticidade neuronal}

O que muda exatamente no encéfalo quando aprendemos e depois lembramos? Tudo que acontece no encéfalo depende de alterações na comunicação (sinalização) entre neurônios, que, por sua vez, dependem de atividade de determinadas moléculas dentro dos neurônios.

Cada neurônio contribui para o comportamento e para a atividade mental, conduzindo ou deixando de conduzir impulsos. O processo de memorização é complexo, envolvendo sofisticadas reações químicas e circuitos interligados de neurônios em diferentes regiões cerebrais.

Os neurônios, quando são ativados, desencadeiam a liberação de substâncias químicas (neurotransmissores) nas sinapses, se comunicando geralmente com dendritos de outros neurônios. Assim, para que as memórias sejam criadas, é preciso que as células nervosas formem novas interconexões e novas moléculas de proteína.

As alterações celulares decorrentes da aprendizagem e memória são

\footnotetext{
${ }^{18}$ Esta forma de memória é sustentada pela atividade elétrica de neurônios do córtex pré-frontal. Esses neurônios interagem com outros, através do cortex entorrinal, inclusive do hipocampo, durante a percepção, aquisição ou evocação.
} 
chamadas de plasticidade. Toda vez que você aprende alguma coisa ou adquire alguma experiência, as células do seu cérebro sofrem uma alteração que refletirá em seu comportamento.

Assim sendo, a plasticidade neuronal é definida como sendo a propriedade do sistema nervoso que permite o desenvolvimento de alterações estruturais em resposta à experiência, e como adaptação a condições mutantes e a estímulos repetidos.

\subsubsection{Localização das estruturas encefálicas envolvidas no processamento da memória}

A memória não está localizada em uma estrutura isolada no cérebro; ela é um fenômeno biológico e psicológico envolvendo uma aliança de sistemas cerebrais que funcionam juntos. As principais regiões encefálicas envolvidas no processamento da memória estão descritas a seguir.

O lobo temporal é uma região no cérebro que apresenta um significativo envolvimento com a memória. Ele está localizado abaixo do osso temporal (acima das orelhas), assim chamado porque os cabelos nesta região frequentemente são os primeiros a ser tornarem brancos com o tempo.

Existem consideráveis evidências apontando esta região como sendo particularmente importante para armazenar eventos passados.

O lobo temporal contém o neocórtex temporal, que pode ser a região potencialmente envolvida com a memória a longo prazo.

Nesta região também existe um grupo de estruturas interconectadas entre si que parece exercer a função da memória para fatos e eventos (memória declarativa), entre elas está o hipocampo, as estruturas corticais circundando-o e as 
vias que conectam estas estruturas com outras partes do cérebro.

O hipocampo ajuda a selecionar onde os aspectos importantes para fatos e eventos serão armazenados e está envolvido também com o reconhecimento de novidades e com as relações espaciais, tais como o reconhecimento de uma rota rodoviária.

A amígdala, por sua vez, se comunica com o tálamo e com todos os sistemas sensoriais do córtex, através de suas extensas conexões. Os estímulos sensoriais vindos do meio externo como som, cheiro, sabor, visualização e sensação de objetos, são traduzidos em sinais

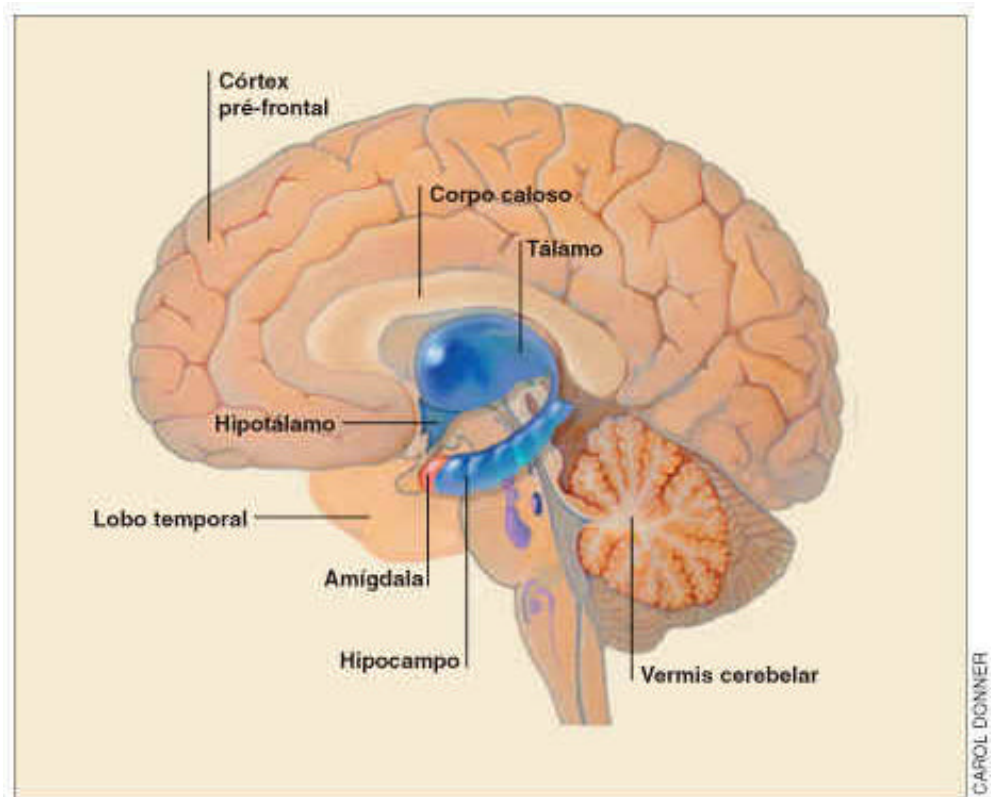
elétricos, e ativam um circuito na amígdala que está relacionado à memória, o qual depende de conexões entre a amígdala e o tálamo.

Conexões entre amígdala e hipotálamo, onde as respostas emocionais provavelmente se originam, permitem que as emoções influenciem a aprendizagem, porque elas ativam outras conexões da amígdala para as vias sensoriais, por exemplo, o sistema visual.

O Córtex pré-frontal exibe também um papel importante na resolução de problemas e planejamento do comportamento. Uma razão para se acreditar que o córtex pré-frontal esteja envolvido com a memória, é que ele está interconectado com o lobo temporal e o tálamo. 


\subsubsection{A evocação e o esquecimento}

As memórias não são armazenadas de forma integral e, mesmo estabelecidas e consolidadas, não são permanentes. Este é o fenômeno do esquecimento: somos melhores na generalização e na abstração de conhecimentos do que na retenção de um registro literal de eventos. O esquecimento é fisiológico e ocorre continuamente, enfraquecendo o traço de memória do que foi aprendido. De fato, esquecer é uma função essencial ao bom funcionamento da memória: seria impossível, e pouco prático, evocar com riqueza de detalhes todas as informações que necessitamos num único dia.

Para Iván Izquerdo, não existe dúvida de que o aspecto mais notável da memória é o esquecimento. Embora possamos armazenar tantas experiências quanto possível, podemos dizer que tão importante quanto o armazenamento de informações é o seu esquecimento. O fenômeno do esquecimento é fisiológico e desempenha um papel adaptativo. Imagine só se fôssemos capazes de "guardar" tudo aquilo que vivenciamos com uma riqueza de detalhes, seria praticamente impossível, pois levaríamos boa parte do nosso tempo recordando cada detalhe vivenciado.

No conto Funes, o memorioso, o escritor Jorge Luis Borges relata a história de Funes, uma pessoa que tinha uma memória fantástica e nunca esquecia de nada. Esse personagem lembrava de absolutamente tudo e, por causa disso, não conseguia pensar de forma genérica. E, ao não ter a capacidade de esquecer, diminuía em muito sua capacidade de aprender.

Ainda resta considerar a diferença entre as memórias esquecidas e as 
memórias extintas. As memórias esquecidas permanecem latentes e não são evocadas, a menos que ocorra uma circunstância especial como a apresentação, de uma forma muito precisa, do estímulo (da situação) utilizado para adquiri-las e/ou com uma intensidade muito aumentada, uma "dica" muito apropriada. As memórias extintas podem ser evocadas, as memórias esquecidas não. A extinção se produz no hipocampo e na amígdala basolateral e requer expressão gênica, síntese de proteínas e vários outros processos bioquímicos e tem uma clara aplicação terapêutica no tratamento de fobias: síndrome do pânico, ansiedade generalizada e, sobretudo, estresse pós-traumático.

A evocação da memória, por sua vez, não é simplesmente a reativação de fragmentos distribuídos que constituem o engrama, representação da informação no sistema nervoso. Lembrar implica num processo ativo de reconstrução e não se assemelha a assistir a uma fita de vídeo do passado. Pode acontecer que apenas alguns fragmentos do engrama sejam ativados, ou podemos confundir pensamentos e associações provocados diretamente pela mesma dica, e vários estudos têm demonstrado a falibilidade da memória humana.

Além disso, o humor e a motivação também podem influenciar o quê, e o quanto, nós lembramos; este fenômeno é denominado de dependência de estado.

O conteúdo emocional das memórias também afeta a maneira como são armazenadas e, portanto, a sua evocação, a facilidade com que são lembradas. Por exemplo, as pessoas recordam especialmente bem eventos acompanhados de elevada emocionalidade. As emoções melhoram a memória declarativa (aquela para fatos, idéias e eventos, e toda a informação que pode ser trazida ao reconhecimento consciente e expressa através da linguagem) através da ativação da amígdala. 


\subsubsection{Enfim, o resumo...}

A memória é um processo dinâmico e está sujeita à ativação de diferentes funções mentais e encefálicas, o que a torna bastante variável para o mesmo indivíduo e mais ainda de indivíduo para indivíduo. O desempenho da memória depende da combinação entre aspectos de maturação nervosa, de contexto e da demanda atencional, emocional e motivacional da atividade realizada.

Você ainda lembra do texto do Guimarães Rosa, que foi citado no início deste capítulo? Que memória!Talvez valha a pena recordá-lo:

Contar é muito dificultoso. Não pelos anos que já se passaram. Mas pela astúcia que tem certas coisas passadas de fazer balancê, de se remexerem dos lugares. A lembrança da vida da gente se guarda em trechos diversos: uns com os outros acho que nem não misturam. Contar seguido, alinhavado, só mesmo sendo coisas de rasa importância. Assim é que eu acho, assim é que eu conto. O senhor foi bondoso de me ouvir. Tem horas antigas que ficaram muito mais perto da gente do que outras de recente data. O senhor mesmo sabe; e se sabe, me entende. Toda saudade é uma espécie de velhice (ROSA, apud: MACHADO, 1989, p. 78).

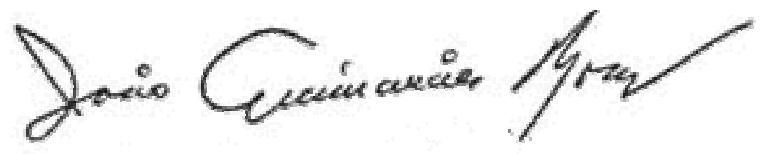

Regina Machado já chamou Guimarães Rosa de o mago da palavra. Esse brilhante escritor também pode ser considerado o mestre da memória. Não apenas por sua excelente memória e erudição.

Mestre, pois com a simplicidade que só os sábios adquirem, codificou, armazenou e evocou, de forma única: A Memória com Ciência e Arte. 


\title{
2.4 Aprendizado e mudança anatômica do córtex cerebral
}

Aprender é mudar! Mudar por dentro e por fora. Quem aprende de verdade muda o jeito de pensar a vida, muda a forma de falar, muda a postura do andar!

Se pensar, falar e andar são atos coordenados pelo encéfalo, então algo deve ser mudado também no interior do encéfalo para que a pessoa possa se manifestar de uma maneira diferente. Será que quando aprendemos algo e o registramos como memória(s), algo também se altera no encéfalo? Essa pergunta é respondida por Eric Kandel, prêmio Nobel de medicina e fisiolgia em 2000:

\begin{abstract}
À medida que adquirimos novas informações e armazenamos como memórias, acredita-se que novas alterações anatômicas se estabeleçam no encéfalo. Esse princípio simples tem profundas implicações. Uma vez que todos somos criados em ambientes de certo modo diferentes e temos, de alguma forma, diferentes experiências, a arquitetura do encéfalo de cada pessoa é modificada de forma única. Mesmo gêmeos idênticos, não terão encéfalos idênticos, pois certamente terão experiências de vida diferentes (KANDEL, 2003, p. 212).
\end{abstract}

Desde o começo do século XX que Ramon y Cajal $^{19}$ postulou corretamente que "O homem é o escultor de seu próprio cérebro". Na década de 1950, também um dos pioneiros da pesquisa em comportamento biológico, Donald Hebb, acreditava que a memória implicava em mudanças estruturais nos circuitos neurais. Porém, naquela época, esses cientistas ainda não dispunham de evidências experimentais para que suas hipótese pudessem ser comprovadas.

\footnotetext{
${ }^{19}$ Santiago Ramón y Cajal, prêmio Nobel de medicina e fisiologia em 1906, é considerado o pai da neurociência (ver anexo III).
} 
Nos últimos 20 anos houve um grande avanço nas neurociências, especialmente em relação aos mecanismos fisiológicos e moleculares da formação, consolidação e evocação da memória. Atualmente, está estabelecido que a aprendizagem pode levar a alterações estruturais no encéfalo. A cada nova experiência do indivíd uo, constata-se que redes de neurônios ${ }^{20}$ são rearranjadas, outras tantas sinapses são reforçadas e múltiplas possibilidades de respostas ao ambiente tornam-se possíveis. A experiência pode se dar por uma aprendizagem ativa ou pela convivência em lugares enriquecidos com indivíduos, cores, música, sons, livros, cheiros e outros estímulos.

Este processo de modificação sináptica é chamado de plasticidade neuronal. Cada experiência vivenciada estimula o processo de plasticidade neuronal em diferentes espécies, que vão desde os invertebrados até os humanos. Define-se a plasticidade neuronal como sendo a propriedade do sistema nervoso que permite o desenvolvimento de alterações estruturais em resposta à experiência, e como adaptação a condições mutantes e a estímulos repetidos.

A plasticidade neuronal está presente em todas as etapas do desenvolvimento, inclusive na fase adulta e durante o envelhecimento. A capacidade de modificação do sistema nervoso em função de suas experiências, tanto em indivíduos jovens como em adultos, foi reconhecida apenas nas últimas décadas (ROSENZWEIG, 1996).

A neuroanatomista americana Marian Diamond (1987) realizou um experimento com ratos, que tem sido muito comentado e constantemente citado. Ela foi capaz de demonstrar que os animais que foram criados em um ambiente

\footnotetext{
${ }^{20}$ Os neurônios são células especializadas, cuja principal função é comunicar-se com outros neurônios e com os órgãos que realizam as ações (como os músculos e o coração). Em conseqüência do processamento de uma fantástica quantidade de informações, a atividade integrada dos neurônios determina e modula o comportamento dos indivíduos.
} 
enriquecedor, uma gaiola cheia de brinquedos e dispositivos, tais como bolas, rodas, escadas, rampas, etc., desenvolviam um córtex cerebral significativamente mais espesso do que aqueles criados em um ambiente mais limitado, sem os brinquedos ou vivendo isolados. O aumento da espessura do córtex não era devido apenas a um maior número de células nervosas (natural da etapa do desenvolvimento do rato); mas havia também um aumento expressivo de ramificação de seus dendritos e das interconexões com outras células, conforme está ilustrado na figura abaixo.
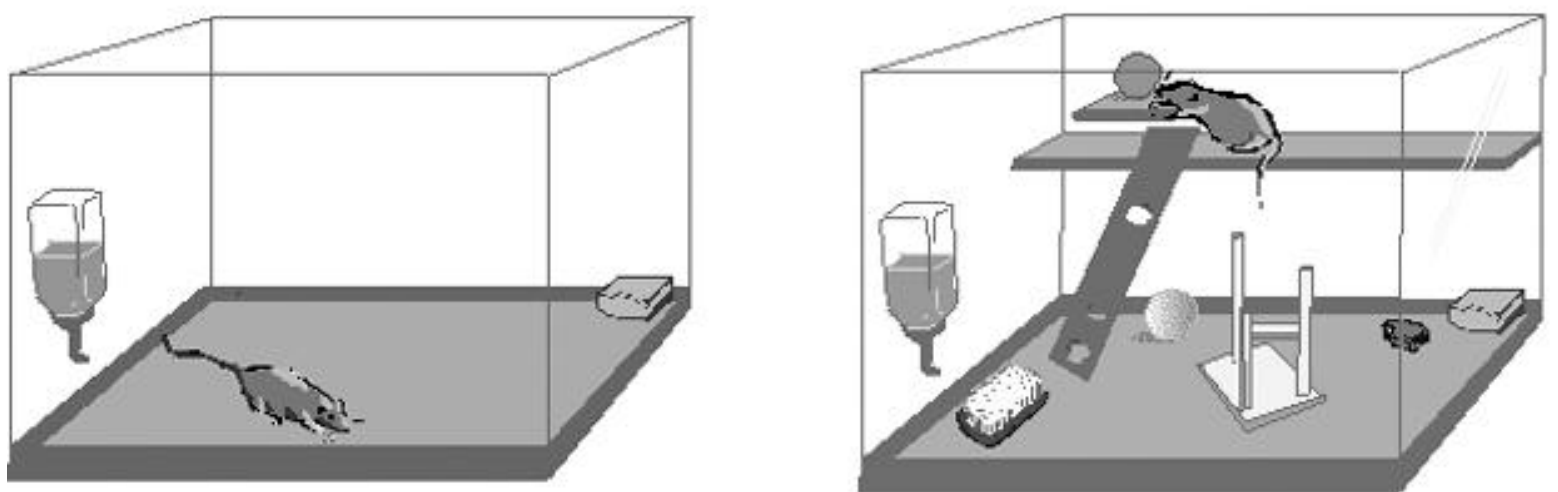

\begin{tabular}{|l|l|l|} 
(Stellates) \\
Ambiente pobre em objetos
\end{tabular}




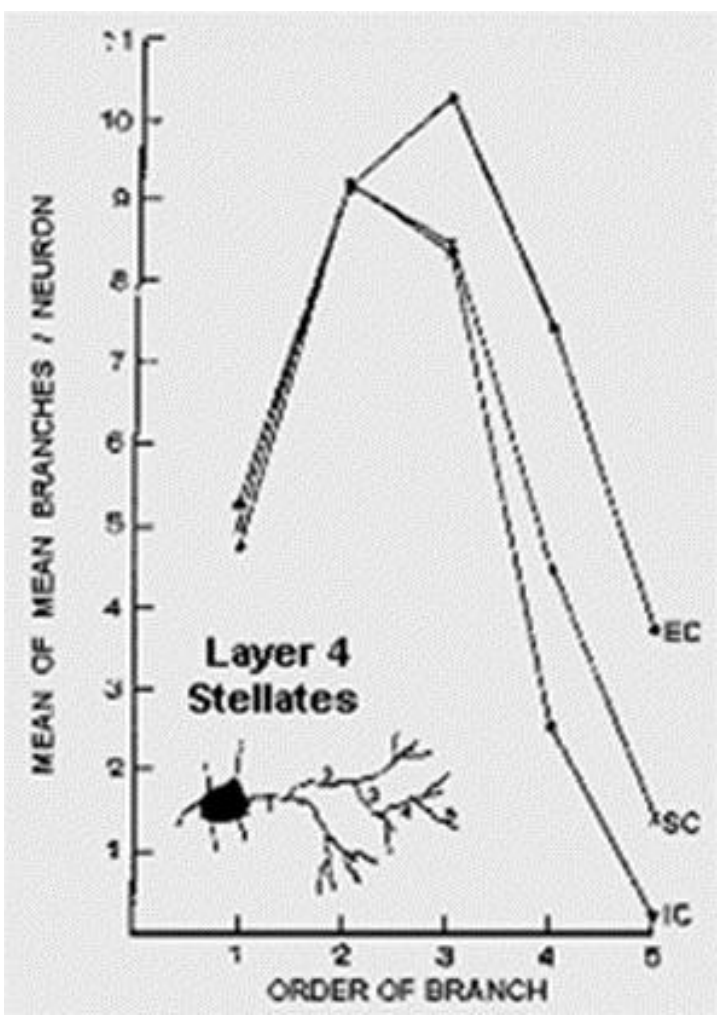

O gráfico à esquerda mostra como o número médio de ramificações observadas nas células estelares ${ }^{21}$, que são encontradas na quarta camada do córtex visual do rato, é maior nos animais criados em ambientes enriquecedores (reta identificada como EC, isto é, condição enriquecedora) do que nos animais criados juntos em grupos sociais, (identificados como SC, ou condição de grupo social), porém desprovidos de brinquedos. Por sua vez, os ratos SC apresentam um número maior de ramificações nas células estelares do que os animais criados isolados e sem brinquedos (IC, ou grupo de condição de isolamento). Uma diferença ainda maior pode ser vista nas ramificações de quarto e quinto níveis. Em outras palavras: as ramificações originadas do corpo da célula não aumentam devido a uma experiência sensorial, motora ou social mais rica; o inverso é verdadeiro para as ramificações no ponto dos longos processos neuronais. Isso constitui uma evidência de que as células estelares crescem e geram novas ramificações naquelas pré-existentes, e isso é um resultado muito significativo.

As partes das células estelares que crescem são os dendritos ${ }^{22}$, e consequentemente, o crescimento das ramificações dos dendritos só pode significar que os processos de intercomunicação nas células do córtex ${ }^{23}$ aumentaram e que

\footnotetext{
${ }^{21}$ Células estelares são neurônios arredondados e seus axônios não deixam o Córtex, sua função é estabelecer as conexões com as colunas corticais.

${ }^{22}$ É através dos dendritos que um neurônio recebe os impulsos nervosos de outras células, que são transmitidos através do corpo celular e, a partir daí, para o axônio.

${ }^{23}$ Córtex é a camada mais externa do cérebro. A espessura do córtex cerebral varia de dois a seis milímetros.
} 
mais dendritos torna-os mais efetivos em termos de regulação da atividade dos circuitos neuronais.

Esse aumento de densidade sináptica desenvolvido em ambientes motivacionalmente enriquecidos foi constatado em ratos. Não está provado, ainda, com o devido rigor científico, que o mesmo ocorra com seres humanos.

Embora ainda não existam evidências diretas, tais como as observadas por Diamond em ratos, é do conhecimento científico o fato de que as tarefas de ativação mental são acompanhadas por muitas mudanças, tais como mudanças no metabolismo cerebral (consumo de glucose por células cerebrais, aumento do fluxo e temperatura do sangue). Essas mudanças podem agora ser observadas diretamente através de novos instrumentos de imagens computadorizadas, como, por exemplo, as imagens por ressonância magnética funcional (RMf) e a tomografia de emissão de pósitron (PET).

Fluxo Sanguíneo Cerebral (CBF) durante uma tarefa de ativação mental. O sujeito controle normal, linha de base (esquerda) e tarefa matemática (direita). Nesse indivíduo, o aumento da perfusão durante as tarefas matemáticas é visível tanto na área frontal inferior e parietal esquerda.

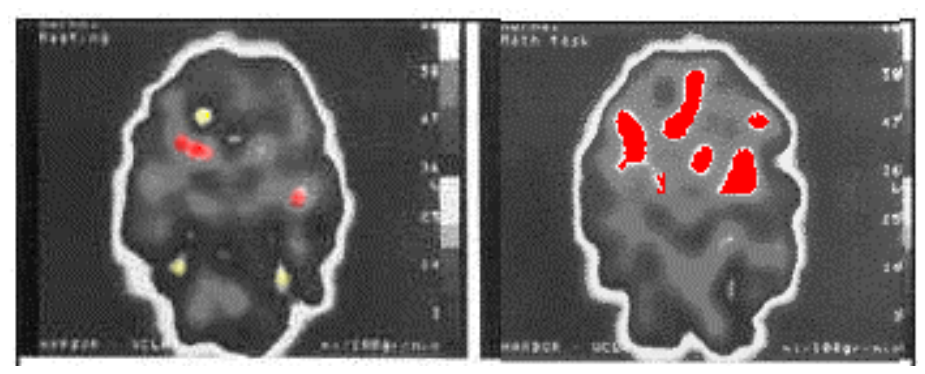

Fonte: Villanueva-Meyer et. cols. - Alasbimn Journal

No passado, sem as técnicas de imagem do cérebro, era difícil coletar provas neurocientíficas diretas da aprendizagem de humanos. Até pouco tempo, os 
cientistas acreditavam que, uma vez completado seu desenvolvimento, o cérebro era incapaz de mudar, particularmente em relação às células nervosas, ou neurônios.

Hoje já está estabelecido que o encéfalo, mesmo tendo uma estrutura arquitetônica pré-estabelecida, é passível de permanentes mudanças construtivas, assim como também são o repertório comportamental e as memórias do indivíduo. As evidências científicas indicam que a plasticidade sináptica é a responsável pela capacidade de transformação dos neurônios e pela aquisição das memórias, e que a manutenção de atividades criativas e estimulantes pode melhorar a evocação da memória. Embora alguns desses prováveis mecanismos já tenham sido identificados, ainda há muito a ser descoberto e decifrado. A memória e a plasticidade estão, sem dúvida, entre as mais interessantes e enigmáticas fronteiras das neurociências.

Existem suficientes evidências que demonstram que a educação e o entorno emocional esculpem o encéfalo e modificam sua forma de processar a informação. Esse processo ocorre através da ativação de partes específicas do encéfalo, em resposta a estímulos externos fundamentais, como o movimento, a percepção e as emoções.

A compreensão das vantagens e limitações das tecnologias de imagem do encéfalo é o primeiro passo para entender como a neurociência cognitiva poderá colaborar com a educação. Para os educadores, os resultados advindos destas pesquisas podem trazer uma importante contribuição para a elaboração de currículos que levem em conta as características do funcionamento encefálico. 


\section{ARTE}

\subsection{A arte e a evolução da espécie humana}

A Terra foi formada há aproximadamente cinco bilhões de anos; a vida surgiu há cerca de 3,5 bilhões de anos, homenídeos, definidos pelo hábito de caminhar como bípedes, provavelmente evoluíram de um macaco africano há cerca de seis milhões de anos. A partir dos Australopithecus, desenvolveram-se espécies mais parecidas com os humanos, entre elas o Homo habilis, o Homo erectus, o Homo de nienderthalis e o Homo sapiens arcaico.

Um vasto período de milhões de anos separa o

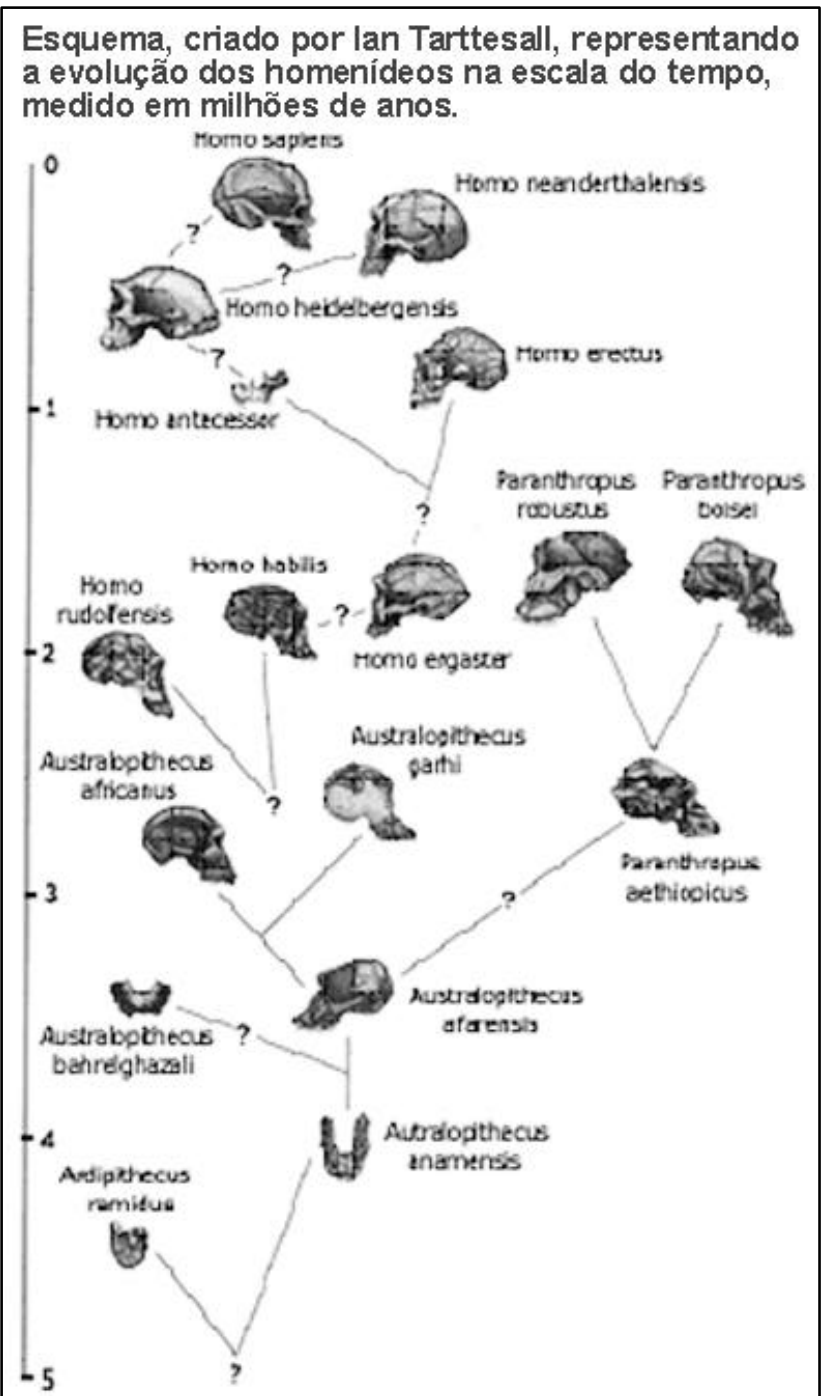

Esquema, criado por lan Tarttesall, representando medido em milhões de anos. 
arcaico e o Homo neanderthalensis.

O comportamento dessas três espécies Homo, a 150 mil anos atrás, não denotava muita diferença. Porém, surgem indícios de que algo singular estava ocorrendo:

No Oriente Médio, vemos o Homo sapiens sapiens não apenas enterrando seus mortos dentro de covas - como, na verdade, também fazem o Homo neanderthalensis - mas depositando partes das carcaças de animais junto aos mortos, aparentemente como se fossem oferendas. Na África do Sul estão usando torrões de ocre vermelho ${ }^{24}$, e também afiando pedaços de ossos para fazer arpões. São os primeiros utensílios feitos de outro material que não a pedra ou a madeira (MITHEM, 2002, p. 36).

Outro marco acontece a aproximadamente 60 mil anos, no Sudoeste da Ásia, o Homo sapiens sapiens constrói embarcações e faz a primeira travessia até a Austrália. No Oriente Médio as lascas de pedras agora são longas e finas: parecem de fato camadas de lâminas. Porém, é na África e na Europa, por volta de 50 mil anos atrás, que rapidamente o cenário se transforma ${ }^{25}$. A restrita série de ferramentas de pedra agora deu lugar a uma grande diversidade de objetos fabricados com vários materiais diferentes, incluindo osso e marfim. O Homo sapiens sapiens começa a mudar o entorno que lhe cerca com comportamentos inéditos construindo moradias, costurando vestimentas com agulhas de osso, esculpindo, pintando nas paredes, enterrando os mortos e criando ornamentos. O Homo sapiens arcaico e o Homo neanderthalensis aos poucos desaparecem, o Homo sapiens

\footnotetext{
${ }^{24} \mathrm{O}$ ocre vermelho é uma forma de minério de ferro.

${ }^{25} \mathrm{Na}$ áfrica do Sul o arqueólogo norueguês Christopher Henshilwood descobriu a Caverna Blombos, com uma coleção impressionante de ferramentas sofisticadas e artefatos ornamentais que datam de 75 mil anos. As descobertas de Blombos oferecem forte evidência de que pelo menos um grupo de Homo sapiens possuía a mentalidade moderna antes de 50 mil anos. Os artigos foram publicados em 2001 e 2002.
} 
sapiens agora claramente estabelece o ritmo e se torna a única espécie de Homo sobre a face da terra.

Esse período do Paleolítico Superior (cerca de 50 mil anos atrás), marcado por abruptas transições no comportamento da espécie humana, é denominado pelos arqueólogos de explosão cultural, ou despertar do ser humano ou o big bang da cultura humana.

Ainda que existam diversas discordâncias sobre como e quando surgiu o despertar cultural, existe consenso entre os arqueólogos com relação aos seguintes fatos referentes a esta época:

- a produção de ferramentas mais especializadas, nas quais a forma e o tipo de pedra são adequados à tarefa a ser realizada;

- o aparecimento de sofisticadas formas de representação artística, variando de estatuetas às pinturas nas cavernas de Chauvet ${ }^{26}$, na França;

- uma explosão nos artigos cuja função é decorativa ou ornamental: os dentes, os escudos, os pingentes perfurados;

- as primeiras evidências de sepultamento de indivíduos com objetos depositados em seus túmulos.

Como a explosão cultural foi realizada pelo Homo sapiens sapiens não a partir do momento em que este surge no mundo, mas após terem transcorridos

\footnotetext{
${ }^{26}$ No dia 18 de dezembro de 1994, Jean-Marie Chauvet e mais dois exploradores descobriram uma caverna, na França, que foi, posteriormente, batizada de Chauvet em homenagem a seu descobridor. A exploração revelou quatro câmaras de galerias em uma extensão de cerca de 500 metros. Juntas, as quatro câmaras continham mais de 300 animais pintados e gravados, juntamente com pontos, padrões geométricos e gravações a mão por meio de estêncil. Essas pinturas foram datadas entre 32 mil e 31 mil anos atrás. É possível realizar uma visita virtual a essa caverna acessando o seguinte endereço: <http://www.culture.gouv.fr/culture/arcnat/ chauvet/en/>.
} 
pelo menos 70 mil anos, surge a seguinte pergunta: $O$ que teria ocorrido com 0 Homo sapiens sapiens? Qual(is) evento(s) teria propiciado tamanha mudança comportamental?

Infelizmente não há resposta conclusiva para essa questão. Para situar-nos melhor é necessário lançar novamente um olhar no caminho sinuoso da evolução. A evolução humana percorreu um caminho de desvios e viradas e encontrou impasses ocasionais. A parte mais antiga da nossa história ainda permanece bastante obscura. Dizemos que foi quando criaturas com aparência de macacos se acostumaram a caminhar sobre as duas pernas. A partir dessa inovação essencial, a evolução humana pode ser vista como uma série de pelo menos três, ou talvez quatro eventos repentinos e profundos espaçados ao longo de grandes períodos de tempo em que pouca coisa ocorreu.

Richard Klein, paleantropólogo na Universidade de Stanford, argumenta o seguinte:

Até 50 mil anos atrás, a anatomia e o comportamento humanos parecem ter-se desenvolvido de maneira relativamente lenta, mais ou menos harmoniosa. Após o período de 50 mil anos, a evolução anatômica cessou, enquanto a revolução comportamental se acelerou de forma acentuada. Pela primeira vez havia desabrochado entre seres humanos a capacidade para a produção de cultura, baseada numa quase infinita aptidão para inovar (KLEIN, 2002, p.19).

\subsubsection{Hipóteses de como ocorreu o despertar}

Qual teria sido o(s) eventos(s) ocorridos com o Homo sapiens sapiens que proporcionou o surgimento do despertar cultural? 
Muitos arqueólogos que tentaram explicar o despertar cultural defendem uma causa estritamente social, tecnológica ou demográfica, é o caso de Randall White, Sally McBrearty e Allison Brooks, que postulam que a circunstância que talvez mais tenha estimulado comportamentos culturais avançados foi 0 crescimento populacional. A presença de mais pessoas aumentava a pressão sobre recursos, forçando nossos ancestrais a divisar maneiras mais inteligentes de obter comida e material para a fabricação de ferramentas. Mais gente também elevava as chances de encontros entre os grupos. Contas, pintura corporal e mesmo manufatura de ferramentas estilizadas podem ter funcionado œmo indicadores da filiação e do status de um indivíduo em um clã, o que teria sido importante em situações de disputa por recursos escassos.

Nos últimos anos, um número pequeno, mas crescente, de arqueólogos como Christopher Henshilwood, passou a rejeitar as teorias que pregam uma grande explosão cultural em favor de um modelo fundamentalmente diferente. Segundo eles, não houve atraso entre o desenvolvimento do corpo e da mente. Em vez disso, argumentam, o comportamento humano moderno desenvolveurse durante um longo período, num processo mais apropriadamente descrito como evolução do que revolução.

Steven Mithen, arqueólogo da Universidade de Reading, constrói um argumento em que compara o funcionamento da mente com o funcionamento do canivete suíço, para explicar essa questão:

Observamos realmente uma explosão cultural começando há cerca de 43 mil anos na Europa, com a produção dos primeiros trabalhos artísticos, e eu sugeriria que isso pode ser explicado por novas conexões entre os domínios das inteligências técnica, social, naturalista. Os três processos cognitivos, antes isolados, agora funcionavam juntos, criando o novo processo cognitivo que podemos chamar de simbolismo visual, ou simplesmente arte (Mithen, 2002, p. 262). 
Uma pequena minoria, a exemplo de Richard Klein, defende uma causa biológica, apoiada na suposição de uma mutação genética.

Os próprios arqueólogos salientam que, ao contrário do despertar em si, suas explicações são mais uma questão de crenças pessoais ou de filosofia que de provas.

As mudanças expressas pelo comportamento ${ }^{27}$, no período do despertar cultural, que são estudadas através de indícios e vestígios nas pesquisas arqueológicas, apontam uma relação direta com o desenvolvimento neurofisiológico de nossos ancestrais. Afinal, não é possível o ser humano planejar e executar uma ação sem haver uma atuação neuronal correspondente e competente para a finalidade em questão. Portanto, alguns fatores devem ter favorecido um desenvolvimento maior da capacidade cognitiva, que até então vinha sendo demonstrada.

Uma explicação neurológica para a explosão cultural após o marco de 50 mil anos não atende a um importante critério para avaliação da validade de uma hipótese científica: ela não pode ser testada ou refutada pela experimentação ou pelo exame de fósseis humanos relevantes. Os encéfalos humanos chegaram ao tamanho atual centenas de milhares de anos antes, mas os crânios pouco revelam sobre o funcionamento dos encéfalos que eles continham. Não há nada nos crânios datados de um período anterior em torno de 50 mil anos atrás que mostre a ocorrência de uma mudança neurológica significativa. A hipótese neurológica, no entanto, corresponde a um critério científico importante: constitui a explicação mais

\footnotetext{
${ }^{27}$ As duas transformações comportamentais realmente impressionantes, associadas exclusivamente ao Homo sapiens sapiens, aconteceram muito depois do tamanho do encéfalo humano moderno ter evoluído. A primeira foi o despertar cultural entre 50 mil e 30 mil anos atrás e inclui o aparecimento dos artefatos artísticos, da tecnologia complexa e da religião. A segunda foi o início das atividades agrícolas com o cultivo de plantas e domesticação de animais, cerca de 11 mil anos atrás.
} 
simples e econômica para a evidência arqueológica disponível. E, é nessa evidência, mesmo incompleta e imperfeita, que devemos confiar para reconstruir o nosso passado evolutivo.

É ponto pacífico que temos de observar o encéfalo para compreender os processos cognitivos em qualquer espécie. Os cientistas que estudam a evolução do encéfalo sugerem que um aumento relativo no tamanho desse órgão, possivelmente aumentou a quantidade de informações que o encéfalo humano poderia processar, o que permitiu o desenvolvimento de modelos mentais mais sofisticados. O encéfalo é um órgão de processamento de informação, e desde o Australopithecus, o encéfalo humano aumentou quase três vezes de tamanho. $\mathrm{O}$ aumento desse órgão só se tornou possível graças às mudanças ocorridas na circulação sanguínea, o que permitiu que um encéfalo de maior tamanho fosse adequadamente resfriado e nutrido. Tal evolução foi estimulada provavelmente pela seleção natural de padrões de comportamento mais complexos.

Porém, a partir do Homo sapiens sapiens que surgiu há cerca de 150 mil anos atrás, o tamanho do encéfalo, determinado pelas medidas dos crânios pertencentes aos fósseis encontrados, não mais apresenta alterações anatômicas.

O renomado neurocientista Eric Kandel, da Columbia University, argumenta:

Os seres humanos têm a capacidade única de comunicar para os outros aquilo que aprenderam, e, assim, podem criar culturas que podem ser transmitidas de geração em geração. As realizações humanas parecem expandir-se sempre, porém 0 tamanho do encéfalo humano aparentemente não aumentou de forma significativa desde que o Homo sapiens apareceu, de acordo com os registros fósseis, há diversas centenas de milhares de anos. $\mathrm{O}$ que determinou mudanças culturais e progressos durante esses milhares de anos não foi um aumento do tamanho do encéfalo, tampouco uma mudança em sua estrutura. Foi, antes de tudo, a capacidade intrínseca do encéfalo humano de capturar o que aprendemos pela fala e pela escrita e de ensinar tais coisas a outros (KANDEL, Memória, p.14). 
Na constituição do encéfalo existe um elemento vital, responsável pela habilidade cognitiva referente à simbolização, é o córtex pré-frontal, a partir do qual vários comportamentos podem ser formulados. Conforme comenta Antonio Damásio, neurologista da Universidade de lowa, essa é uma área do cérebro considerada como o centro executivo, responsável pelo pensamento abstrato e simbólico, por planejar o futuro, dirigir a atenção para uma tarefa, modular o afeto e as emoções, assim como adiar uma gratificação e lidar com as frustrações. Além disso, essa área está intimamente ligada às funções de resolver problemas novos, planejar a ação futura, a atenção, a memória, a percepção e o seqüênciamento temporal. É também a área na qual se apresenta a maior diferença, ao comparamos o encéfalo da nossa espécie e dos outros animais (DAMÁSIO, 2001).

Porém, somente com o desenvolvimento do córtex pré-frontal ainda não haveria possibilidade do Homo sapiens sapiens manifestar os comportamentos registrados durante o despertar cultural. O córtex pré-frontal funciona de maneira integrada com outras estruturas encefálicas, responsáveis pelo mecanismo neurofisiológico da atenção, da percepção, da memória e de nossas ações (comportamentos).

Como Marcus Vinícius Baldo, professor de Fisiologia Sensorial do Instituto de Ciências Biomédicas da Universidade de São Paulo, ICB/USP, apontou:

O sistema nervoso evoluiu de tal forma que uma grande complexidade estrutural e funcional foi alcançada não tanto pelas vias aferentes, responsáveis por canalizar as informações sensoriais, ou pelas vias eferentes, responsáveis por emitir as respostas motoras, mas por circuitos que intermedeiam essas vias de entrada e saída. Os complexos circuitos neurais que se localizam entre as vias sensoriais e motoras são os principais responsáveis 
pela riqueza, flexibilidade e plasticidade de nossos comportamentos. Isso se manifesta na enorme diversidade de estímulos que podem ser reconhecidos por nossos sistemas sensoriais, na multiplicidade de graus de liberdade com que nossas ações são organizadas pelos sistemas motores e, sobretudo, pela rica plástica relação que se estabelece entre esses dois conjuntos. Não só possuímos um grande repertório de respostas comportamentais para um conjunto de estímulos oriundos do ambiente, mas podemos, além disso, alterar e ajustar respostas já existentes, ou ainda criar novas respostas, tornando nosso repertório comportamental cada vez mais otimizado e adaptado ao ambiente (BALDO, In: CURI (org), 2007).

O neurocientista V. Ramachandran, considerando que uma das descobertas mais importantes das neurociências nos últimos tempos são os chamados neurônios-espelho ${ }^{28}$, especula que estes poderiam ter um significado importante no surgimento do despertar:

A mudança possivelmente ocorrida no Homo sapiens foi uma adaptação genética que deu a neurônios-chave a capacidade de espelhamento que eles têm agora, abrindo caminho para avanços acelerados na compreensão, comunicação e aprendizado. Pela primeira vez, a informação podia ser espalhada, ampliada e modificada para criar a dinâmica intelectual e social da cultura. Os neurônios-espelho foram cruciais no desenvolvimento de habilidades sociais elaboradas, redes sociais e infra-estrutura de conhecimento que chamamos cultura - do uso de ferramentas ao deleite com Shakespeare, da caça colaborativa ao hip-hop (Scientific American, ano XIV, no 161, p. 51).

As considerações expostas acima expõem o contexto em que se insere a hipótese neurológica, a evolução do encéfalo humano e o aparecimento das

\footnotetext{
${ }^{28}$ Os neurônios são a unidade básica do sistema nervoso e operam em grandes conjuntos, como unidades funcionais de informação. Esses conjuntos de neurônios associados formam os chamados circuitos ou redes neurais que constituem o encéfalo. O neurônio-espelho é um tipo específico de neurônio descoberto em 1996.
} 
funções cognitivas modernas. Aliás, uma explicação de como esse novo fenômeno extraordinário surgiu continua sendo ao mesmo tempo a questão mais intrigante e desconcertante da biologia.

\subsubsection{Origens da arte}

Ao buscar as possíveis origens da arte, podemos recuar com segurança a cerca de 50 mil anos, quando surgem os artefatos considerados artísticos pelos arqueólogos, no início do período Paleolítico Superior. Esta época, considerada o despertar do ser humano, representa de fato o momento no qual o homem demonstra a sua capacidade cognitiva de trabalhar com símbolos, a sua habilidade absolutamente moderna de produzir cultura.

O registro arqueológico mostra que a arte do Paleolítico Superior não é um produto de circunstâncias confortáveis, realizada num tempo ocioso; ela foi criada por indivíduos que viviam sob condições de grande estresse. O florescimento da arte paleolítica na Europa ocorreu em condições ambientais extremamente duras, na época da última glaciação. As paisagens se tornaram extremamente gélidas na medida em que as placas de gelo começaram a retrair-se e o clima alterna-se drasticamente entre períodos de clima úmido e períodos de clima frio e seco, terminando com um rápido período de aquecimento global, há 10 mil anos.

\subsubsection{Critérios para que os arqueólogos considerem um artefato como arte}

A definição de arte é específica de cada cultura e também difere através dos tempos. Na verdade, muitas das sociedades que criam maravilhosas pinturas rupestres não têm uma palavra que denote a arte nas suas línguas. Para a 
inclusão de algum artefato na categoria arte, os arqueólogos consideram que este deve ser uma representação figurativa ou indique pertencer a um código simbólico, por exemplo, pela repetição dos mesmos motivos. A fase mais inicial do Paleolítico Superior oferece um vasto panorama de exemplos dos dois casos. Vários sítios foram explorados na Ásia, na Europa e na África, nos permitindo uma visão amplificada do possível significado da arte para o desenvolvimento do ser humano.

Em relação à arte figurativa da Europa Central podemos citar quatro sítios datados com cerca de 33 mil anos: Vogelherd, Hohlenstein-Stadel, Geibenklösterle, todos na Alemanha, e Stratzing/Krems-Rehberg, na Áustria. A maior coleção individual, dez estatuetas, é originária de Vogelherd Cave, e consiste em dois mamutes, um cavalo, três felinos, um baixo relevo de cabeça de mamute, um baixo relevo de leão, um bisão totalmente esculpido, uma cabeça de leão e uma figura antropomórfica.

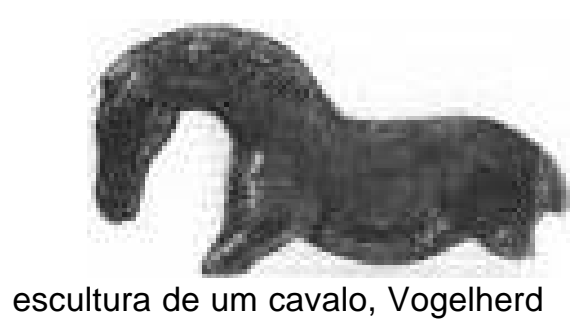

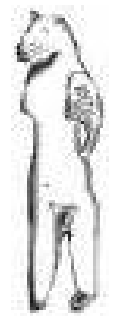

homem-leão, Vogelherd

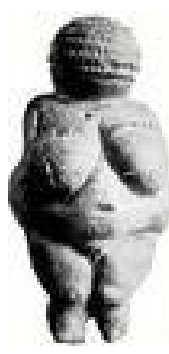

Vênus, Willendorf

As pinturas rupestres da caverna de Chauvet, na França, descobertas em 1994, foram datadas com carbono-14 e têm cerca de 30 mil anos de idade. A gruta de Chauvet se abre numa sucessão de vastas salas por uma extensão de 500 metros. Ela não era habitada, uma vez que fragmentos de sílex talhado e os restos de animais trazidos pelo homem são raros. Em compensação, fragmentos muito numerosos de carvão vegetal, provenientes provavelmente de tochas e fogueiras para iluminação ou para fabricação de pigmentos, estão presentes no chão. Cerca de 425 figuras de animais foram encontradas, isoladas ou reunidas em grandes 
composições. Esses animais frequentemente representados em movimento, distinguem-se por seu naturalismo e dinamismo. A natureza dos animais representados e as técnicas utilizadas tornam essas figuras excepcionais. Os mais

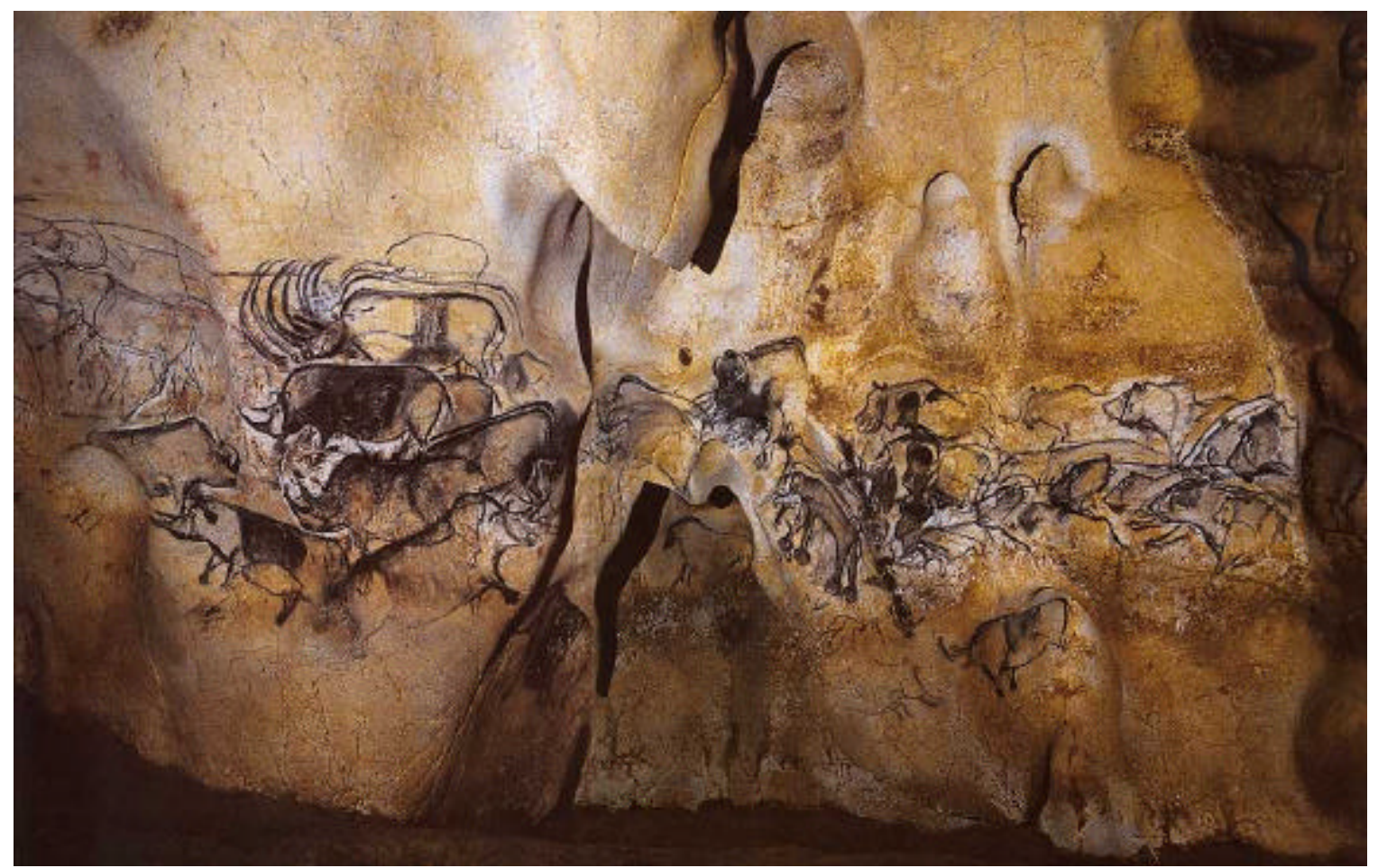

abundantes são os rinocerontes (65), os leões (74) e os mamutes (66). Os cavalos,

as renas, os bisões e uma coruja; representados em menor número, são igualmente pinturas extraordinárias.

\section{Essa caverna}

está no mesmo nível da

caverna de Lascaux, e certamente da de Altamira, na Espanha, no que diz respeito à natureza espetacular da sua arte.

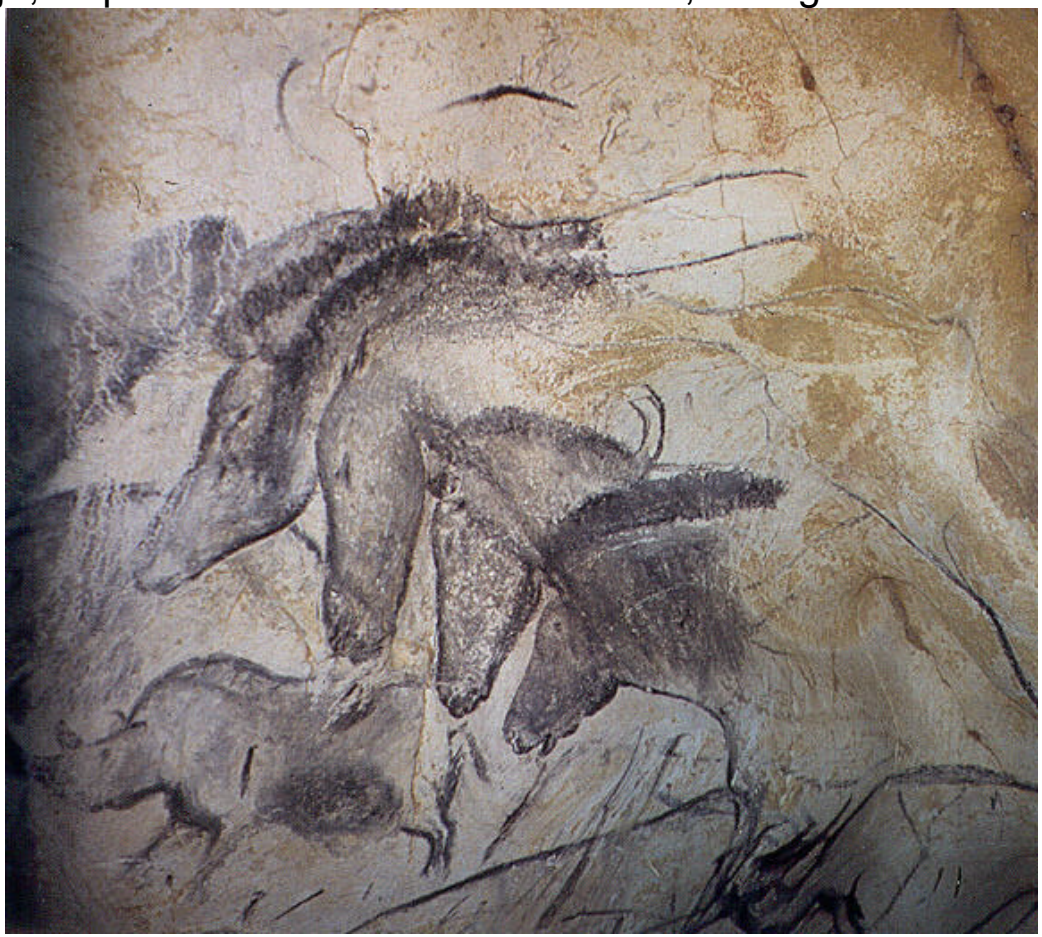


Steven Mithen, arqueólogo da Universidade de Reading, faz um breve inventário que traça um panorama da produção artística deste período:

Na África, descobriram-se placas de pedra de 27,5 mil anos de idade onde foram pintadas representações de animais, e contas de cascas de ovos de avestruz de 39 mil anos de idade. $\mathrm{Na}$ Ásia Oriental, as primeiras contas datam de 18.000 a 13.000 anos atrás e provêm da caverna de Longgupo, na China. Gravações em argila nas paredes de cavernas da Austrália forma datadas de 23.000 - 15.000 anos atrás, e é provável que parte da arte rupestre seja tão antiga quanto 40.000 anos. Nos abrigos em rochas de Mandu Mandu descobriu-se uma coleção de vinte mil contas feitas de conchas e datadas de 34.000 - 30.000 anos atrás (MITHEN, p. 43).

As evidências arqueológicas mostram que, por volta de 30 mil anos atrás, a capacidade de realizar arte era um atributo universal da mente humana moderna. E isso implica na capacidade de gerar símbolos visuais. Embora a definição de um símbolo visual seja notoriamente difícil, Steven Mithen (2002, p. 255) aponta pelo menos cinco propriedades cruciais para que um objeto possa ser considerado um símbolo visual:

- A forma do símbolo pode ser arbitrária em relação ao referente. Essa é uma das características fundamentais da linguagem, mas também se aplica aos símbolos visuais. Por exemplo, o símbolo "2" não se parece com dois em nada.

- Um símbolo é criado com a intenção de comunicar.

- Pode ocorrer uma defasagem espaço-temporal considerável entre um símbolo e seu referente. Por exemplo, eu poderia desenhar uma imagem de algo que aconteceu há muito tempo, ou de algo que 
penso que possa acontecer no futuro.

- O sentido específico de um símbolo pode variar entre indivíduos e, de fato, entre culturas. Isso freqüentemente depende dos seus conhecimentos e experiências.

- O mesmo símbolo pode tolerar um certo grau de variabilidade, seja ele imposto deliberadamente ou não. Por exemplo, somos capazes de entender a letra de diferentes pessoas, embora as formas específicas de cada letra não sejam iguais.

Um bom exemplo de símbolos visuais, que podem ser considerados arte em rochas, durante o paleolítico, é a imagem de uma série de curvas encaixadas em formato de $\mathbf{U}$ em Natal Drakensberg, que estão circundadas por pequenos insetos voadores (Lewis-Willians, 1995). A pintura representa uma colméia, provavelmente refletindo a grande predileção que todos os caçadorescoletores têm pelo mel. Entretanto, Lewis-Williams também explica como é provável que essa imagem tenha um significado entrópico e também reflita o trabalho de xamãs. Mithen considera que

Realmente, não há como duvidar que as imagens criadas no Paleolítico Superior também possuíam significados múltiplos e simbólicos complexos, que envolvem as cinco propriedades já relacionadas. Os aqueólogos têm mais chances de reconstruir o sentido "externo" da arte que os significados "internos", os quais exigem um acesso ao mundo mitológico perdido da mente da préhistórica (MITHEN, 2002, p. 258). 
Randall White ${ }^{29}$, arqueólogo especialista no estudo da arte portátil (do tipo que se encontra no solo) do Paleolítico Superior, sugere que a dificuldade em definir o que é arte tem sido um sério impedimento para explicar sua origem. Dentre as várias pesquisas que já realizou encontra-se um estudo detalhado no sítio de La Souquette, no sudoeste da França. Neste local foram encontradas peças consideradas ornamentos pessoais; são uma produção de contas de marfim que foram gravadas imitando conchas do mar. Após extenso levantamento da distribuição desses itens por toda Europa, e pesquisa demonstrando o tempo e o esforço extraordinários para que cada conta de marfim fosse manufaturada (cerca de três horas cada), White enfatiza que deveríamos conceber essas contas como objetos de arte, em vez de banalizá-las chamando-as de simples objetos decorativos.

Randall White acredita que as contas de marfim, as conchas perfuradas, os dentes furados de animais e outros ornamentos ou objetos de arte portáteis são tão simbólicos quanto os rinocerontes de carvão vegetal desenhados pelos artistas aurignacianos do início do Paleolítico Superior nas paredes da caverna de Chauvet, ou do bisão multicor pintado pelos magdalenianos no final do Paleolítico, no teto de Altamira. As populações do Paleolítico Superior quase sempre retratavam os animais que caçavam ou comiam, a julgar pelos fragmentos de comida encontrados nos sítios. Mas também mostravam comumente espécies que pouco caçavam e deviam ser raras na paisagem. Portanto, a escolha dos temas das pinturas era

\footnotetext{
${ }^{29}$ A pesquisa de White, arqueólogo da Universidade de Nova York, mostra que a produção de contas dos primeiros aurignacianos exigia tempo e esforço extraordinários, o que ressalta a possibilidade de terem um sentido simbólico. O processo de manufatura envolvia passos múltiplos, a saber: modelar uma haste em marfim ou em pedra macia, buscando um formato semelhante ao de um lápis; inserir sulcos ou ranhuras com a distância de um a dois centímetros entre elas em volta da haste; aplicar pressão para quebrar as pré-formas cilíndricas de contas entre os sulcos; criar um furo para que elas pudessem ser penduradas, seja com 0 ato de goivar cada pré-forma no interior a partir das extremidades, ou seja com o método de perfuração rotativa; e, finalmente, usar um abrasivo natural para tornar as contas uniformes, raspando-as para que adquirissem um formato padronizado. Os experimentos de White mostram que uma única concha geralmente exigia cerca de uma a três horas de trabalho, mas alguns sítios do Paleolítico Superior contêm centenas ou até mesmo milhares de conchas.
} 
arbitrária, e provavelmente ligava-se às crenças locais sobre a forma de natureza se organizar ou sobre a relação entre a natureza e a sociedade. As populações do Paleolítico Superior eram igualmente arbitrárias ao produzir ornamentos ou objetos de arte portáteis, e a escolha variava amplamente ao longo do tempo e do espaço. No primeiro intervalo aurignaciano, antes do período de 30 mil anos atrás, os povos produziram contas de marfim e colares de dentes de animais, sobretudo na França e na Rússia; perfuravam conchas para pendurá-las em áreas que hoje compreendem a Espanha, a França, e a Itália; produziram esculturas tridimensionais de animais, essencialmente na Europa Central; e gravavam em blocos de calcário apenas numa área pequena do sudoeste da França. Já que nenhum dos dbjetos era utilitário, a escolha do que produzir estava quase com certeza enraizada nas variadas crenças locais sobre a ordem natural ou social (WHITE In: KLEIN, 2004 p. 219).

Contas, pingentes e outros objetos usados como adornos, com freqüência são descobertos em túmulos, de maneira marcante nos túmulos de 28 mil anos de idade de Sungir, na Rússia. Neste local foram encontrados os túmulos de um homem de 60 anos e de dois adolescentes, de sexo masculino e feminino. Cada um desses indivíduos foi adornado com milhares de contas de marfim,

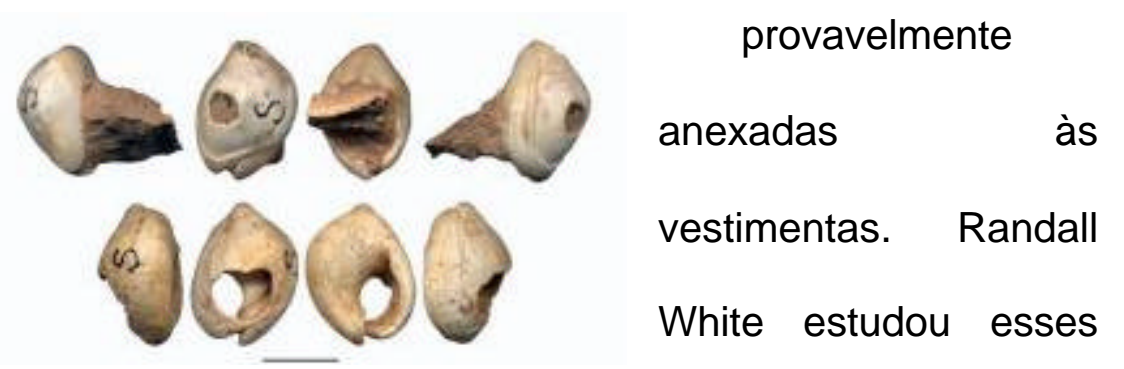
túmulos e fornece as seguintes descrições:

O homem foi adornado com 2.936 contas e fragmentos dispostos em linhas encontradas em todas as partes de seu

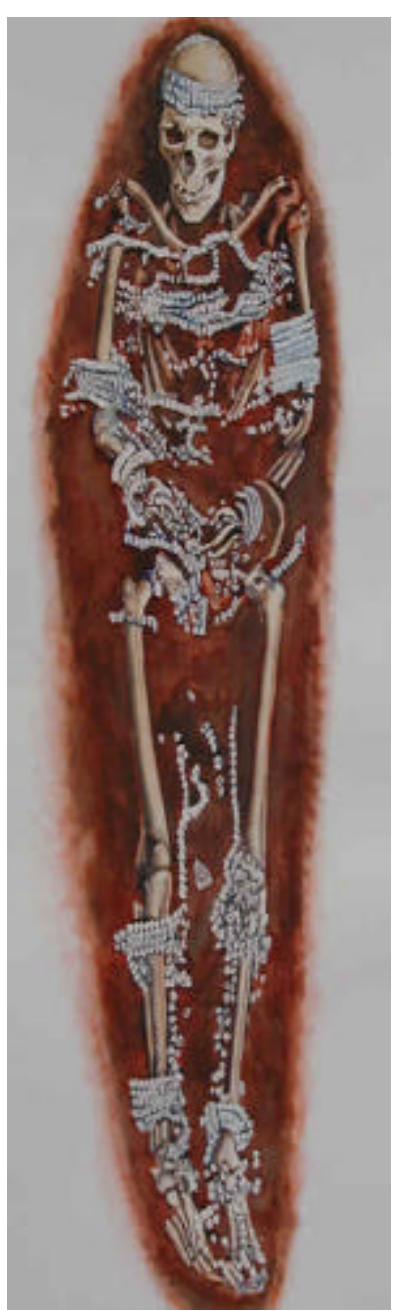


corpo; sua cabeça foi aparentemente coberta por um capelo adornado com contas e vários dentes de raposa. Seus braços e antebraços foram ambos decorados por uma série de (25 ao todo) braceletes de marfim polido de mamute, alguns exibindo traços de tinta preta... Ao redor de seu pescoço exibia um pequeno pingente liso de xisto, pintado de vermelho, mas com um pequeno ponto preto em um dos lados... O que se presume ser um rapaz estava coberto de contas em linha - 4.903 delas - de aproximadamente 2/3 do tamanho das contas do homem, embora exatamente do mesmo formato. Ao contrário do homem, no entanto, ele tinha em torno de sua cintura - aparentemente os restos de um cinto decorado mais de 250 caninos de raposa polar. Sobre seu peito encontrava-se um pingente de marfim escarvado na forma de um animal. Em sua garganta repousava um alfinete de marfim, aparentemente o fecho de algum tipo de capa. Sob seu ombro esquerdo havia uma grande escultura de um mamute de marfim. À sua esquerda repousava um segmento médio de fêmur humano muito robusto e extremamente polido, cuja cavidade medular estava preenchida de ocre vermelho. À sua direita... via-se uma pesada lança de marfim, feita a partir de uma presa lanosa de mamute aprumada... Próxima a ela está um disco entalhado de marfim disposto verticalmente no solo. Aquela que presumivelmente era uma moça tinha 5.274 contas e fragmentos (com tamanho de também aproximadamente 2/3 daquele das contas do homem) cobrindo seu corpo. Ela também usava um capelo de contas e trazia igualmente um alfinete de marfim em sua garganta, mas no seu túmulo não se encontrava nenhum dente de raposa, nem trazia pingentes em seu peito. Todavia, de ambos os lados encontrava-se um número de pequenas "lanças" de marfim, mais apropriados ao tamanho de seu corpo do que do rapaz que a acompanhava. Também ao seu lado estão dois bastões furados feitos de chifre de veado, um dos quais decorado com trilhas de pontos escarvados. Finalmente, ela estava acompanhada por uma série de três discos de marfim perfurados no centro e treliça, semelhante à aquela adjacente ao dos restos do presumido rapaz. (In: MITHEN, 2002, p. 278). 
Realmente é difícil estabelecer uma divisão entre o que é uma artefato artístico, um ornamento, um instrumento ou uma ferramenta. As interpretações variam de acordo com a concepção de arte que for adotada. Muitas ferramentas podem, na verdade, ser considerados um tipo de instrumento totalmente novo: um artefato de arte. $\mathrm{E}$ todos os tipos de artefatos refletem uma integração entre a capacidade criativa, o ambiente social e o meio ambiente do indivíduo.

\subsubsection{Processos cognitivos simbólicos}

Em fevereiro de 2006, na Rádio BBC de Londres, um programa de entrevistas e debates (disponível na internet) cujo tema era: The day we learned to think, reuniu um grupo de renomados arqueólogos. Entre eles estavam Richard Klein (Stanford University), Alison Brooks (George Washington University), Terrence Deacon (University of Califórnia, Berkeley), Randall White (Universidade de Nova York), Jean-Jaques Hublin (University of Bordeaux) e Chris Henshilwood (Universidade de Bergen, Noruega). A discussão girou em torno das evidências encontradas em vários sítios arqueológicos que assinalam quando deixamos de ser animais e nos tornamos realmente humanos.

Richard Klein considera que:

[...] se tivesse que apontar um fato isolado que pudesse ser considerado uma marca do homem moderno, essa seria a capacidade de inovar, a criatividade, a habilidade de introduzir e inventar coisas novas o tempo todo. Nenhuma outra espécie demonstra essa característica em seu comportamento (KLEIN, apud: BBC, 2006).

Já para Radall White, "Considera-se um marco evolutivo as evidências da aquisição e manipulação da linguagem através dos símbolos. A aquisição da 
habilidade de falar, de conferir significado ao mundo ao redor, de pensar, as maneiras de comunicar e socializar informações”(WHITE, apud: BBC, 2006).

Os dois arqueólogos, embora desenvolvam distintas linhas de raciocínio e argumentos no decorrer de suas pesquisas, e cheguem a conclusões diferentes para explicar o despertar cultural; nesta ocasião sintetizaram em suas falas as habilidades consideradas marcantes na evolução da espécie humana. 0 que essas proezas comportamentais têm mais claramente em comum é possuir como fundamento a aquisição de processos cognitivos simbólicos. Esses processos naturalmente só existem a partir de um encéfalo suficientemente desenvolvido, capaz de dar suporte neurológico a esses comportamentos.

Segundo lan Tattersal, curador da divisão de antropologia do Museu Americano de História Natural, em Nova York:

Esses processos cognitivos simbólicos referem-se à habilidade de abstrair elementos da experiência e representá-los com símbolos mentais individuais, como elementos distintos. Ao separar os elementos dessa forma, os seres humanos são capazes de recriar constantemente na mente o mundo e aspectos individuais dele. $\mathrm{E} O$ que torna isso possível é a habilidade de formar e manipular símbolos mentais correspondentes aos elementos que percebemos dentro e fora de nós mesmos. Membros de outras espécies em geral apresentam níveis altos de raciocínio intuitivo, reagindo a estímulos do ambiente de forma um tanto complexa, mas apenas os seres humanos são capazes de combinar e recombinar símbolos mentais de forma arbitrária e fazer questões como "E se?”. É a habilidade de fazer isso, acima de todo o resto, que constitui a base de nossa propalada criatividade (Scientific American, Especial Evolução, p. 72). 
Com a utilização dos processos cognitivos simbólicos, o ser humano habilita-se a produzir arte. Portanto, podemos sugerir que a arte, é um fenômeno cultural produzido e reconhecido através do sistema cognitivo do ser humano. Esse sistema provavelmente teve sua evolução neurofisiológica com o desenvolvimento do córtex pré-frontal e uma crescente elaboração de nossos circuitos neurais, indispensáveis para que o Homo sapiens sapiens apresentasse a capacidade de formular e executar os comportamentos expressos no decorrer do despertar cultural.

\subsubsection{Conclusão}

No estudo dos seres humanos modernos, é importante reconhecer que grande parte de nosso comportamento não é inato ao sistema nervoso, mas, sim, culturalmente aprendido. A capacidade de produzir cultura, baseada numa forte aptidão para inovar, acabou desenvolvendo uma capacidade sem precedentes do ser humano se adaptar ao ambiente, provavelmente pela conjunção do desenvolvimento neurofisiológico do ser humano e da cultura por este produzida. Isto deu origem ao círculo cada vez mais rápido de feedback positivo, e nestas condições a evolução cultural ganhou um ritmo espantoso e continuamente acelerado, que continua até os dias de hoje.

Nosso ancestral, o Homo sapiens sapiens, com o utilização do encéfalo, desenvolveu a capacidade de formular representações simbólicas, como a fala e a linguagem, a arte pictórica, a escultura, a música, os adornos corporais, as ferramentas, a ciência, a domesticação de animais, a agricultura, e as crenças espirituais, como os ritos funerais. Todas essas invenções são produtos de um processo cultural, e são transmissíveis entre seres humanos através do aprendizado. 


\subsection{Arte, percepção, observação e cognição}

Entre nossas características culturais únicas, a arte é talvez a mais nobre invenção humana. Ou, de outra forma, a arte é uma das mais inquietantes e eloqüentes produções do homem.

O ser humano tem produzido arte há cerca de 50 mil anos. Ao longo desse período, a arte tem apresentado diversos formatos, já que está intimamente vinculada ao seu tempo. Por isso que, ao buscarmos definições para arte, podemos esbarrar em conceitos até contraditórios e que pouco a pouco foram sendo incorporados pela cultura.

Luigi Pareyson, filósofo da arte italiano, em seu livro Os problemas da estética, argumenta sobre as definições da arte. Ele considera:

As definições mais conhecidas da arte, recorrentes na história do pensamento, podem ser reduzidas a três: ora a arte é concebida como um fazer, ora como um conhecer, ora como um exprimir. Estas diversas concepções ora se contrapõem e se excluem umas às outras, ora, pelo contrário, aliam-se e se combinam de várias maneiras. Mas permanecem, em definitivo, as três principais definições da arte (PAREYSON,1989, p. 32).

$\mathrm{Na}$ Antiguidade a arte foi entendida como um fazer em que era, explícita ou implicitamente, acentuado o aspecto executivo, fabril, manual. Desde essa época estabeleceu-se um equívoco, que é a falta de distinção entre a arte propriamente dita e o ofício ou a técnica do artesão.

$\mathrm{Na}$ época do romantismo, prevaleceu a terceira definição da arte, a arte como expressão, que fez com que a beleza da arte consistisse não na adequação a 
um modelo ou cânone externo de beleza, mas na beleza da expressão, isto é, na íntima coerência das figuras artísticas com o sentimento que as anima e suscita.

A concepção da arte como um conhecer aparece em todo decurso do pensamento ocidental. Nessa definição, Pareyson argumenta que

[...] a arte é interpretada como conhecimento, visão, contemplação, em que o aspecto executivo e exteriorizador é secundário, senão supérfluo, entendendo-o ora como a forma suprema ora como a forma ínfima do conhecimento, mas, em todo caso, com visão da realidade: ou da realidade sensível na sua plena evidência, ou de uma realidade metafísica superior e mais verdadeira, ou de uma realidade espiritual mais íntima, profunda e emblemática (PAREYSON,1989, p. 34).

Essas três concepções revelam características essenciais da arte, contanto que não sejam isoladas entre si ou absolutilizadas.

Considerando o fato de que, em todas as operações humanas também podemos encontrar um caráter expressivo, um caráter cognitivo e um caráter executivo, o que, afinal, distinguiria e qualificaria a arte como tal?

Essa dupla exigência de reconhecer a presença da arte em todas as atividades humanas e especificar a arte, propriamente dita, como atividade distinta das demais, dá lugar a muita discussão e é um importante problema no campo da estética.

O fazer, o expressar e o conhecer fazem parte da concepção, mas não são a manifestação artística. A arte tem como ponto de partida a intenção, e:

[...] qualifica de modo especial e característico as três funções citadas. Por exemplo, ela revela, frequentemente, um sentido das coisas e faz com que um particular fale de modo novo e inesperado, 
ensina uma nova maneira de olhar e ver a realidade; e estes olhares são reveladores sobretudo porque são construtivos, como o olho do pintor, cujo ver já é um pintar e para quem contemplar se prolonga no fazer (PAREYSON,1989, p. 31).

Entre as modalidades que a arte apresenta, estão as artes plásticas, a arte dramática, a arte literária, a arte musical e a dança.

As artes plásticas, também consideradas como artes visuais, incluem tradicionalmente o desenho, a pintura, a gravura, a escultura, o desenho industrial e a arquitetura. No decorrer do processo de formação da cultura, naturalmente o campo de atuação das artes visuais amplia-se, e outras manifestações artísticas que possam ser analisadas sob o ângulo da visão podem ser incluídas. Neste caso, são consideradas também outras modalidades de arte, tais como: a fotografia, as artes gráficas, os quadrinhos, a cenografia, a publicidade, o cinema, a televisão, o vídeo, a computação gráfica e outros tipos de mídia que tenham como característica a visualidade.

Nossa concepção do que significa ver e observar irá moldar a forma como observamos, interpretamos e ordenamos nossa maneira de pensar. Ao aprofundar a maneira de ver, observar, expressar e comunicar as imagens que nos rodeiam (desenhadas, pintadas, gravadas, impressas, modeladas, fotografadas, filmadas, televisionadas, etc) temos a oportunidade de compreendê-las e, consequentemente, transformá-las. Assim, ao invés de meros espectadores de um cenário visual, passamos a interagir ativamente com o ambiente que nos cerca.

\subsubsection{Observar}

O que significa o ato de observar para a vida de uma pessoa? Qual a importância da observação na vida do ser humano? 
A manutenção da vida depende da eficácia com que um indivíduo possa exercer sua habilidade de observar. Ela envolve a observação das reações advindas do funcionamento do próprio corpo, do relacionamento do corpo com o meio que o cerca (possibilitando desde atitudes básicas de sobrevivência, como atravessar uma rua movimentada, até o relacionamento social adequado) e culmina na atitude introspectiva que propicia a formulação de pensamentos e idéias. Portanto, podemos sugerir que a qualidade de vida de uma pessoa é diretamente proporcional a qualidade de suas observações.

Para que a observação se realize é necessário que o sistema atencional seja acionado. William James, psicólogo do séc. XIX, descreveu a atenção da seguinte forma:

Todo mundo sabe o que é atenção. Vai tomando conta da mente, de forma clara e viva, e para aquele que assim não se encontra, vários objetos ou raciocínios parecem simultaneamente possíveis. Focalização, concentração da consciência são sua essência. Isso implica a retirada de algumas coisas de forma a lidar efetivamente com outras, e é uma condição que é oposta ao estado confuso, aturdido, dispersivo... (JAMES, apud: GAZZANIGA, 2006, p. 263).

A Atenção pode ser direcionada de diversas maneiras e com diferente intensidade, conforme a condição que o observador apresenta. A atenção pode ser capturada involuntariamente, em milissegundos, por uma campainha que toca ou por uma luz que pisca intensamente; como também pode ser deliberadamente dirigida ao foco de um interesse pessoal e neste permanecer por minutos ou horas.

A atenção voluntária é aquela que a pessoa, deliberadamente, dirige a 
um objeto. Esse objeto ${ }^{30}$ pode ser tanto externo (referente ao meio exterior do organismo) como interno (referente ao meio interno do organismo).

A atenção voluntária e/ou involuntária é que aciona e modula o funcionamento sincronizado de várias regiões encefálicas, a partir da necessidade ou demanda do organismo.

Ancorada na motivação e no objetivo, a atenção de uma pessoa pode permanecer por horas focalizada em um determinado objeto. Neste caso, a atenção propiciou e manteve a concentração. Os objetos (físicos ou abstratos) que se encontrão a nossa volta, só adquirem existência para nós a partir da atenção que dedicamos a eles.

Observar é apenas uma das maneiras que a pessoa tem de prestar atenção. Para a maioria das pessoas, a noção de observar se restringe aos aspectos da percepção visual. Ao ouvir a sugestão OBSERVE, é quase automático fixar o olhar buscando alguma informação. Mas observar, que é apenas uma das maneiras de dirigir a atenção, é realizado com a participação de todos os sentidos. Observa-se com todos os sentidos (o visual, auditivo, olfativo, gustativo, táctil e proprioceptivo), mesmo que tenhamos a impressão que de estarmos apenas olhando algo.

O ato de observar é parte integrante da vida e é essencial para sobrevivência. Assim sendo, é observando que se aprende, se ensina e se pratica qualquer atividade todos os dias de uma vida.

Quando observamos com as mãos, formamos uma imagem tátil, bem como uma imagem de movimento da mão. Quando observamos com o nariz, formamos uma imagem olfativa, que pode desempenhar um papel importante num

\footnotetext{
${ }^{30}$ A palavra objeto está sendo utilizada no sentido psicológico do termo. Refere-se a qualquer coisa (física ou abstrata) na qual se deposite a atenção.
} 
invento científico ou artístico e assim por diante. O que conseguimos observar, conseguimos imaginar; e o que conseguimos imaginar, conseguimos conceber.

A partir da observação aprendemos a andar, falar, interpretar o significado dos gestos, brincar, escrever, desenhar e tantas quantas sejam as atividades realizadas pelo ser humano.

\subsubsection{A observação, a arte, a ciência e o desenho}

Uma observação apurada se faz necessária tanto para as atividades artísticas como para as atividades científicas. Existem muitos recursos para desenvolver, dirigir, focalizar e ampliar a capacidade de observar (de dirigir a atenção), e uma delas é o desenho.

O desenho é uma notação gráfica realizada a partir das observações (prévias ou posteriores) de um objeto observado. Nesse sentido, o desenho é um instrumento valioso para a ação cognitiva. Pois, enquanto se está desenhando, também se está conhecendo o objeto desenhado. Não apenas a forma, mais alta, mais arredondada, menos acentuada..., mas inclusive as qualidades intrínsecas do objeto observado.

Em se tratando das artes visuais, a palavra observar nos remete, naturalmente, à lembrança do desenho de observação.

Picasso relatou como aprendeu a desenhar com seu pai, que era professor de arte:

Lembro de meu pai me dizendo: 'Vejo de bom grado a idéia de você se tornar pintor, mas não deve começar a pintar enquanto não souber desenhar bem, e isso é muito difícil'. Então ele me deu o pé 
de uma pomba para praticar. Apareceu depois para olhar meu trabalho e criticá-lo. Meu pai me obrigou a desenhar o pé da pomba muitas e muitas vezes. Por fim chegou o dia em que ele me deu permissão para ir em frente e desenhar o que eu quisesse... Quando eu estava com 15 anos, conseguia desenhar rostos e corpos, e composições muito grandes, muitas vezes sem modelos; simplesmente porque, ao praticar com o pé da pomba, aprendi a captar o mistério das linhas, e até de nus. Tendo aprendido a observar uma coisa, aprendi a observar e descrever todas as outras (PICASSO, apud: ROOT-BERNSTEIN, 2001, p. 42).

Desenhar significa concentrar a atenção no objeto (imaginário ou real) e coordenar o sistema motor com o sistema sensorial na execução de uma ação. Ou seja, os olhos (e os outros órgãos sensoriais) têm de ser treinados, tanto na observação (percepção dirigida) quanto na notação, conjuntamente. $O$ ato de observar enquanto se desenha aciona mecanismos neurais que possibilitam que a pessoa possa compreender o objeto observado de outra forma. Esse é um aprendizado que exige tempo e esforço, e as lembranças das horas empreendidas numa tarefa dessa natureza podem lhe remeter a doces ou tortuosas recordações.

Tanto tempo e esforço empregados para aprender a desenhar, será que vale a pena? Será que esse foi um tempo bem empregado ou totalmente desperdiçado? Qual a utilidade de traçar algumas linhas num papel se a pessoa nem ao menos deseja ser artista?

Grandes mestres, tanto artistas como cientistas, compreenderam que a facilidade manual está intrinsecamente ligada à maestria da observação - e viceversa. Na verdade, muitos acreditam que aquilo que a mão não consegue desenhar, os olhos não conseguem enxergar e a mente formular.

Ramón y Cajal, prêmio Nobel em fisiologia e medicina em 1906, 
relatou, em sua autobiografia, que sua capacidade de observar acompanhava seu prazer em desenhar desde a infância:

[...] eu estava com oito ou nove anos e tinha uma irresistível vontade de desenhar, de colorir as paredes recém pintadas da vila com todo tipo de desenhos, cenas militares e touradas... mas como não podia desenhar em casa, pois meu pai considerava o desenho uma distração nefasta... saía ao campo... e desenhava cavalos, carretas, vilarejos e paisagens que me parecessem interessantes... e que guardava como ouro em pó... traduzindo meus sonhos no papel, tendo meu lápis como uma varinha mágica, eu criei o mundo que desejei, habitado por todas aquelas coisas que nutriam meus sonhos... tudo passava através de meu lápis agitado (RAMÓN y CAJAL, 1939, p.18).

O tempo passou, e Cajal, até o final de sua vida, nunca deixou de desenhar. Para ele o desenho era ao mesmo tempo tanto uma maneira de entender o tema escolhido como também uma ferramenta capaz de dar suporte à sua imaginação. E como tudo isso era realizado com prazer, esse ciclo se autoalimentava gerando o que é denominado como um ciclo de feedback positivo.

Ao tornar-se médico e assumir a Cátedra de Anatomia, Cajal passou infinitas horas desenhando e estudando. Ele desenhava o que observava tanto na dissecação dos cadáveres como nas lâminas ao microscópio. Desenhou todas as ilustrações de seus estudos de anatomia geral. A maioria das pessoas provavelmente supõe que ele desenhava diretamente a partir do que via, mas não era assim. Cajal relatou que passava a manhã preparando e observando dúzias de seções do cérebro ou da coluna vertebral. E então, depois do almoço, desenhava aquilo de que se lembrava. Em seguida, comparava seus desenhos com os preparados. Analisava as diferenças, depois desenhava de novo, repetindo esse 
processo muitas e muitas vezes. Só quando os desenhos que fazia de memória captavam a essência do que ele tinha visto numa série inteira de preparados é que os considerava prontos.

Seus desenhos captavam tão acuradamente a essência da anatomia neurológica que, até hoje, mesmo com toda a tecnologia da fotografia digital, muitos autores de livros didáticos ainda os preferem, por sua clareza e concisão. Ao contrário de uma fotografia, que é a imagem de um espécime único, cheio de detalhes desnecessários, os desenhos de Cajal mostram aos estudantes o que eles devem procurar em meio ao aglomerado de detalhes de seus próprios espécimes.

E foi através dessa prática que, e passo em passo, de desenho em desenho, de investigação em investigação, Cajal chegou a formular, testar e comprovar a Teoria Neuronal, com a qual recebeu o premio Nobel ${ }^{31}$.

Como Cajal bem sabia, só olhar, mesmo que pacientemente, não basta. Parte do ato de ver é saber o que olhar ou procurar. Desse modo, o verdadeiro talento consiste em fazer uma discriminação visual que seja ao mesmo tempo sintética e abrangente. E o desenho pode se tornar uma ferramenta valiosa nesse processo.

Cajal descreve sua incessante busca científica com uma metáfora, onde compara as mariposas com os neurônios contidos na massa cinzenta encefálica. "Como el entomólogo a caza de mariposas de vistosos matices, mi atención perseguía, en el vergel de la sustancia gris, células de formas delicadas y

\footnotetext{
${ }^{31}$ O estudo detalhado do sistema nervoso teve início no século XIX. Antes das descobertas de Cajal, os conhecimentos sobre a estrutura individual do sistema nervoso e as conexões entre os neurônios eram puramente especulativos. Essa falta de conhecimento era principalmente devido ao fato que os métodos apropriados para visualizar os neurônios não eram apropriados ou mesmo disponíveis. Entretanto, em 1873, Camillo Golgi desenvolveu um método que pela primeira vez tornava possível observar os neurônios em sua totalidade em preparações histológicas: soma (corpo), dendritos e axônios. Dessa forma, os neurônios marcados com o método de Golgi indicaram os seus detalhes morfológicos refinados, e conduziram, finalmente, à sua caracterização e classificação, bem como ao estudo de suas possíveis conexões, feito por Cajal.
} 
elegantes, las misteriosas mariposas del alma cuyo batir de alas, quién sabe si esclarecerá, algún día, el secreto de la vida mental”. (RAMÓN y CAJAL, 1939, p. 20).

Com seu "lirismo científico", como ele mesmo denominava, Cajal foi capaz não só de observar, classificar e descrever o neurônio, como também visualizou, formulou e comprovou a maneira pela qual os neurônios se comunicam. Na época essa formulação foi surpreendente. (ver anexo)

Kandel apropriadamente percebeu que "o que distinguiu Cajal de seus contemporâneos foi sua capacidade de superar a descrição anatômica. Ele tinha capacidade de olhar para a estrutura estática - uma secção anatômica no microscópio - e obter noções sobre o seu funcionamento.”(KANDEL, 2003, p. 41).

Observar, e traduzir de alguma forma o que observamos, é realmente uma faculdade mental, uma tarefa cognitiva. Não conseguimos sensibilizar a atenção se não soubermos para o que olhar e como olhar. Como escreveu Rudolf Arnheim, "As operações cognitivas chamadas de pensamento não são privilégio de processos mentais superiores ou ulteriores à percepção, mas os ingredientes essenciais da percepção propriamente dita." (ARNHEIM, 1980).

A observação, quando acompanhada pelo desenho, disciplina e reforça a atenção; assim como desenvolve tanto a capacidade de observação (sistema sensorial) quanto de manipulação (sistema motor).

$\mathrm{Na}$ verdade, muitos de nossos maiores cientistas fizeram os cursos regulares de educação artística, entre os quais Louis Pasteur, Joseph Lister, Frederick Banting, Charles Best, Albert Michelson, sir W. Lawrence e sir W. Henry Bragg, Mary Leakey, Desmond Morris, Konrad Lonrenz e Bert Holldobler. Embora as aulas de desenho para cientistas e médicos sejam muito mais raras hoje em dia do que no 
passado, ainda se reconhece que, nas palavras do médico Edmundo Pellegrino, 'A habilidade do médico começa com o olho - seu principal instrumento de diagnóstico... O médico e o artista estão unidos por sua necessidade de uma percepção visual especial. Os dois vêem; mas, para ambos, a visão precisa transcender as aparências. Como diz Paul Klee, A arte não transforma o visível; torna visível. O médico precisa ir além das imagens para compreende o que aflige o paciente (ROOT-BERNSTEIN, 2001, p. 55).

O observar que transcende as aparências poderia ser considerado imaginação? A partir de que ponto uma observação pode tornar-se imaginação? Esses limites não são nítidos. Talvez porque ao observar naturalmente ativemos a imaginação e vice-versa.

É observando e imaginando que novas idéias são concebidas. Essa parece ser uma maneira de estimular e despertar a mente para várias invenções. $E$ era assim que agia Leonardo da Vinci. Leonardo da Vinci recomendava a si mesmo e aos outros:

Observem uma parede cheia de manchas, ou feita com vários tipos de pedras; se você tiver de criar um cenário, poderá descobrir uma semelhança com diferentes tipos de paisagens, ornadas com montanhas, rios, rochas, árvores, planícies, amplos vales e colinas em varias disposições: ou, também, poderá ver batalhas e figuras em ação ou estranhos rostos e trajes, e uma infindável variedade de objetos que podem ser reduzidos a formas completas e bem desenhadas (DA VINCI, apud: KEMP, 2005).

Da Vinci era um grande observador, nenhum de seus precedentes ou contemporâneos produziu nada comparável em alcance, brilho especulativo e intensidade visual. Em seus cadernos de anotações, muitos de seus desenhos são 
acompanhados de palavras, assim como longos textos que escreveu raramente deixavam de ter ilustrações. Leonardo era um supremo visualizador, um mestre manipulador de esculturas mentais, e quase tudo que escreveu se baseava na prática de sua observação e representação.

Para Da Vinci, nenhum conhecimento era válido se não fosse derivado da experiência. Ele atribuía grande valor ao experimento - embora não da maneira sistematicamente moderna, "ciência experimental". Ficava tão satisfeito com as provas derivadas de suas observações dos fenômenos em seu estado natural e com os resultados de experimentos pensados, quanto com os testes controlados usando situações especificamente planejadas. Às vezes, quando realmente realizava um teste planejado, escrevia "sperimentata" sob o desenho correspondente - para indicar que os resultados observados eram conclusivos.

Contudo, é interessante notar que essa forma rigorosa de observar não suprimia sua imaginação. Ao contrário, tão grande era a fertilidade de sua imaginação - que ele chamava de fantasia - que esse modo de observar de "pés no chão" preparou uma sólida base da qual Leonardo pode alçar vôo, de modo surpreendente. O ideal que estabeleceu para sua fantasia era o de expressar grandes verdades sobre a base segura do conhecimento de todas as coisas naturais.

Desde o primeiro momento, ao conceber uma obra, Leonardo da Vinci exercia sua fantasia de um modo extraordinário e inovador. Ele produzia um vulcão cerebral no papel. Observando seus cadernos de anotações, notamos que, em algumas páginas (ao contrário de outras), ele escrevia furiosamente, sobrepondo alternativas em emaranhados densos e pulando de uma parte da folha para outra, cheio de idéias, algumas sugeridas de modo instantâneo, acidental, dentro da 
própria confusão gráfica. Como escreveu:

Oh pintor! Quando compuseres tua narrativa pintada, não desenha os membros das tuas figuras com contornos firmes, ou acontecerá contigo o que acontece com muitos pintores que desejam que cada pequeno traço de carvão seja definitivo... Já refletiste sobre os poetas que, ao compor seus versos, são incansáveis em sua busca da bela literatura e não se importam em apagar alguns daqueles versos a fim de melhorá-los? Portanto, pintor, decide de modo geral a posição dos membros de tuas figuras e atenta primeiro para os movimentos apropriados às atitudes mentais das criaturas na narrativa, mais do que a beleza ou à qualidade de seus membros. Deverias entender que se essa composição rudimentar termina por ser adequada à tua intenção, ela ficará ainda mais satisfatória ao ser, subseqüentemente, adornada com a perfeição condizente a todas as tuas partes (DA VINCI, apud: ZÖLLNER, 2005, p. 60).

Ele percebia claramente que a fantasia (imaginação) abre para o observador um leque de possibilidades, que posteriormente serão selecionadas durante o processo da invenção.

O observar dá sentido a uma sensação e ativa a imaginação. Esse sentido poder ser registrado de diversas formas: desenhando, escrevendo, compondo música, falando, atuando, dançando... Se considerarmos, por exemplo, a literatura, temos que escrever e ler já exige um aprendizado, mas para se tornar um escritor ou poeta, esse aprendizado terá de se estender aos outros domínios. Os domínios da imaginação, da fantasia, da invenção e da criação.

Escrever, como toda e qualquer atividade, também requer uma capacidade de observação aguçada. O escritor, assim como o pintor, ou o ator, ou o cientista, ou o estudante, ou o professor... não só vive experiências, ele as analisa também e as transforma em suas obras. O desenvolvimento da trama verossímil 
depende de um vasto conhecimento de como os outros reagem a palavras, gestos e atos. Estimular a sensação no leitor também depende da percepção da sensação em si mesmo.

Não é por acaso, que tantos poetas e romancistas estudaram as artes visuais, entre eles William Blake, J.W. von Goethe, G. K. Chesterton, Thomas Hardy, Mikhail Lermontov, Alfred, lord Tennyson, Theodore $\mathrm{H}$. White, Henry Miller e e.e.cummings..... William Makepeace Thackeray, por exemplo, não fazia apenas anotações escritas para seus livros, usava também lápis e pincel, com as irmãs Brontë, Antoine Saint-Exupéry, George Du Maurier e J. R. R. TolKien desenhavam a ação que queriam descrever com palavras (ROOT-BERNSTEIN, 2001, p. 54).

\subsubsection{Observar, perceber, memorizar e imaginar}

Nós construímos o conhecimento através de associações feitas ao longo do tempo. A capacidade de recordarmos e utilizarmos esse conhecimento nossa eficácia cognitiva - parece depender de quão bem essas associações organi zaram as informações que retivemos.

Inicialmente, todo conhecimento do mundo é adquirido por meio da observação, da atenção dedicada ao que é visto, ouvido, cheirado, saboreado ou sentido por dentro do corpo. Essas percepções do mundo são importantes para conseguir discernir tipos de ação, abstrair seus princípios, fazer analogias entre as propriedades das coisas, criar modelos de comportamento e inovar de maneira produtiva. Com os resultados dessas ações registramos nossas memórias, formando um repertório mnemônico, com o qual formulamos novas respostas para os desafios que nos rodeiam, gerando assim um ciclo de aprendizado constante. Mas o que guia 
o modo de formular as respostas advém da fluência imaginativa. Da imaginação que é elemento imprescindível no processo cognitivo e que atua desde a facilitação da comunicação humana até a construção de surpreendentes invenções.

O artista e coreógrafo Oskar Schlemmer, em 1942, perto do final da sua vida, percebendo como o seu observar demonstrava a expressão de sua individualidade, comentou:

Recentemente terminei uma série de pinturas, inspiradas no que vejo bem à minha volta: vistas de minha janela emoldurando as janelas vizinhas, feitas à noite, entre as nove e as nove e meia, logo depois do black-out. Quando a noite está caindo e se contrasta com fragmentos de bege-laranja-marrom-branco-preto do interior, produz efeitos óticos incríveis. Estou vivenciando com intensidade desconhecida os efeitos místicos da natureza, e observo que, com o passar dos anos, a gente continua aprendendo a ver de maneiras novas e diferentes (SCHLEMMER, apud: ROOT-BERNSTEIN, 2001, p. 57).

$\mathrm{E}$, com o conhecimento neurocientifico atual, seguramente podemos dizer que, enquanto Schlemmer observava e pintava seus quadros, também estava esculpindo o seu cérebro com o movimento de sua imaginação.

\subsection{0 ensino e a aprendizagem da arte}

Seria, prática da observação, a melhor recomendação a quem deseja passar a vida aprendendo? Sob o meu ponto de vista, a melhor recomendação seria aprender a praticar a observação com arte e a arte da observação.

Observar com arte significa observar de um modo sempre novo. É 
como se você estivesse olhando pela primeira vez aquilo que já viu milhares de vezes, e isso acontece quando o observador se atenta para as qualidades do objeto observado, ou melhor, aos atributos deste objeto, aquilo que oferece sustentação para a existência daquela forma. Esse tipo de observar "renovado" mantém acesa a chama da capacidade de apreender. Manifesta um modo individualizado, particular de prestar atenção.

A arte da observação consiste em, além de observar, ser capaz de vivenciar, experimentar e estabelecer empatia com o que se está observando. Esse tipo de observação conduz o observador a realizar descobertas. Nesse mesmo sentido, o bioquímico Szent-Györgyi afirmou que "A descoberta consiste em ver o que todos vêem e pensar o que ninguém pensou'32. (ROOT-BERNSTEIN, 2001, p. 52).

O físico alemão Albert Einstein ${ }^{33}$ praticava a arte da observação e afirmou categoricamente que, no trabalho criativo, "a imaginação é mais importante que o conhecimento".

\footnotetext{
${ }^{32} \mathrm{O}$ bioquímico Albert Szent-Györgyl descobriu a vitamina $C$ através de algumas observações igualmente rotineiras: "Suponho que fui levado por meu fascínio pelas cores; elas me dão um prazer infantil. Comecei com a pergunta, 'Por que a banana fica marrom quando é cortada?'". Acabou descobrindo que as plantas têm compostos chamados polifenóis que interagem com o oxigênio para produzir cor marrom ou preta - seu equivalente de uma casca de ferida. Essa observação levou Szent-Györgyl à seguinte "Há duas categorias de plantas - aquelas que ficam pretas são danificadas, e aquelas que não têm mudança de cor... Por que não há mudança de cor em algumas plantas danificadas?". A resposta era que essas plantas têm vitamina C, um composto semelhante ao açúcar, que impede a oxidação dos polifenóis e sua transformação em compostos protetores marrons ou pretos. Você pode avaliar o teor de vitamina C de diferentes frutas com bastante precisão simplesmente notando quais as que ficam marrons quando danificadas (banana, por exemplo) e as que não ficam (laranja, por exemplo) (ROOT- BERNSTEIN, 2001, p. 50).

${ }^{33}$ Einstein era um mestre na arte, que teve também expoentes em Galileu e Maxwell, de construir experimentos mentais - produzidos apenas na imaginação e que estão além de nossa capacidade de realizá-los diretamente no laboratório - para refletir sobre os princípios básicos da física. Já em 1895, com 16 anos, começou a refletir sobre a questão do éter e a propagação da luz. Concebeu de início um experimento mental que o acompanharia por 10 anos: o que ocorre se acompanharmos uma onda luminosa com a mesma velocidade dela? Ela ficaria 'congelada', em uma estranha forma de onda não movente? Para Einstein, esse experimento mental juvenil foi o primeiro passo para a teoria da relatividade especial. Em 1902, com dois amigos, Habicht e Maurice Solovine (1875-1958), criou um 'clube' informal, a Academia Olímpia. Leram e discutiram longamente vários autores clássicos, incluindo obras de físicos e filósofos. Nessa última categoria, entre os que mais o influenciaram, estava Poincaré.
} 
Vários educadores percebem o quanto a ação artística acrescenta ao aluno, favorecendo a construção do conhecimento a partir da individualidade e da experiência:

As artes fornecem um dos mais potentes sistemas simbólicos das culturas e auxiliam os alunos a criar formas únicas de pensamento. Em contato com as artes e ao realizarem atividades artísticas, os alunos aprendem muito mais do que pretendemos, extrapolam o que poderiam aprender no campo específico das artes. E, como o ser humano é um ser cultural, essa é a razão primeira para a presença das artes na educação escolar (FERREIRA, 2001, p. 32).

Ana Mae Barbosa, arte educadora brasileira, publicou, em 1975, o livro Teoria e Prática da Educação Artística. Neste livro, no capítulo IV, Arte-Educação: uma Experiência Programada, a autora descreve, sempre relacionando a teoria e a prática da ação artística, o trabalho que realizou na Escolinha de Arte de São Paulo, no período de agosto de 1970 a junho de 1971. Considerando o relato, A teoria posta em prática (p. 77-81) de Ana Mae, fui relacionando as atividades descritas com o funcionamento do sistema nervoso (quadro abaixo). A intenção de realizar esse tipo de análise é mostrar, ao alcance da imaginação do leigo, o intenso trabalho neuronal necessário para realizar uma atividade artística. 


\begin{tabular}{|c|c|}
\hline Ana Mae (trecho de aula) & Comentários \\
\hline $\begin{array}{l}\text { "Colocando a teoria em prática, } \\
\text { nossa primeira tarefa consistiu em } \\
\text { despertar a percepção relacionada } \\
\text { com o fenômeno do movimento, que } \\
\text { é um agente capaz de produzir e } \\
\text { modificar imagens. Procuramos } \\
\text { enfatizar o aspecto dinâmico do } \\
\text { objeto, levando as crianças ao } \\
\text { Jockey Clube de São Paulo, onde } \\
\text { tiveram oportunidade de observar } \\
\text { cavalos em movimento, correndo, } \\
\text { treinando, comendo, etc. A } \\
\text { concentração em um objeto - } \\
\text { cavalo - fez com que fosse } \\
\text { ressaltada a sua diversidade de } \\
\text { ação. O ponto de apoio do } \\
\text { observante deslocou-se para a ação, } \\
\text { para o movimento, ao invés de se } \\
\text { deter apenas nas qualidades do } \\
\text { objeto. A fluência foi a habilidade } \\
\text { mental que se pretendeu } \\
\text { desenvolver, exercitando o } \\
\text { pensamento visual no sentido de } \\
\text { captar o maior número possível de } \\
\text { diferentes categorias de ação". }\end{array}$ & $\begin{array}{l}\text { Despertar a percepção está colocado no sentido de } \\
\text { gerar, construir novos perceptos, tendo como foco } \\
\text { atencional o movimento dos cavalos. Quando } \\
\text { focamos nossa atenção voluntariamente, estamos } \\
\text { acionando determinadas áreas encefálicas e } \\
\text { aumentando nestas a quantidade de potenciais de } \\
\text { ação, intensificando a comunicação neuronal que } \\
\text { ali se estabelece. Desta atividade neuronal, } \\
\text { conforme sua intensidade e continuidade, é } \\
\text { possível a formação de memória de longa duração, } \\
\text { crescimento de dendritos e modificação anatômica. } \\
\text { A ênfase no movimento aciona os neurônios de MT } \\
\text { (medial temporal) ou V5 localizados na via dorsal, } \\
\text { que terão sua atividade potencializada. Produzir e } \\
\text { modificar imagens significa realizar uma atividade } \\
\text { intensa em todas as vias do sistema visual com a } \\
\text { participação efetiva do córtex frontal. Ao observar o } \\
\text { movimento também o sistema motor se coloca em } \\
\text { alerta, basta lembrar da função dos neurônios- } \\
\text { espelho. Se a atividade proposta fosse apenas o } \\
\text { desenho de observação, a área encefálica mais } \\
\text { intensamente ativada seria na via ventral, que é } \\
\text { especializada no reconhecimento da cor e da forma } \\
\text { dos objetos, determinando o que é que estamos } \\
\text { olhando. Nesta atividade, perceptos também se } \\
\text { formam, mas a atividade encefálica é mais } \\
\text { localizada e envolve menor número de vias. }\end{array}$ \\
\hline $\begin{array}{l}\text { "Outra preocupação foi explorar o } \\
\text { objeto em diferentes contextos e } \\
\text { observar as modificações em sua } \\
\text { aparência, embora suas qualidades } \\
\text { permanecessem as mesmas. Nesse } \\
\text { sentido, organizamos uma visita a } \\
\text { duas lojas de objetos variados - } \\
\text { roupas, sapatos, flores, carros, } \\
\text { brinquedos, bicicletas etc. -e } \\
\text { depois a um jardim público, próximo } \\
\text { a ruas bem movimentadas, onde as } \\
\text { crianças puderam observar os } \\
\text { mesmos objetos em outro contexto: } \\
\text { em uso e em ação, no caso de } \\
\text { roupas, automóveis, etc.; e em seu } \\
\text { ambiente natural, no caso das flores } \\
\text { e folhagens. O objetivo era expô-las } \\
\text { a diferentes aspectos de uma mesma } \\
\text { realidade, enfatizando a fluência } \\
\text { perceptiva." }\end{array}$ & $\begin{array}{l}\text { O sistema nervoso tem uma maneira própria de } \\
\text { trabalhar. Conhecer como este sistema opera } \\
\text { possibilita potencializar o seu desempenho. As } \\
\text { Teorias da Gestalt, propostas por psicólogos } \\
\text { experimentais, muito contribuíram para o } \\
\text { entendimento de como a percepção se processa. } \\
\text { (ver anexo Gestalt). Na descrição da atividade } \\
\text { acima foram vivenciadas as constantes das forças } \\
\text { de organização que os gestaltistas chamam de leis } \\
\text { de organização da forma perceptual. São esses } \\
\text { princípios que explicam porque vemos as coisas de } \\
\text { determinada maneira e não de outra. O ato de } \\
\text { observar e comparar nas diversas cenas cotidianas, } \\
\text { o texto e o contexto; a figura e o fundo; direciona o } \\
\text { sistema atencional que procede uma busca por } \\
\text { varredura. Além disso, ao manter a concentração } \\
\text { no tema proposto, o sistema nervoso tem } \\
\text { possibilidade de gerar perceptos reforçados, uma } \\
\text { vez que serão gerados com a ativação neuronal } \\
\text { sincronizada de uma maior variedade de vias. }\end{array}$ \\
\hline
\end{tabular}




\begin{tabular}{|c|c|}
\hline Ana Mae (trecho de aula) & Comentários \\
\hline $\begin{array}{l}\text { "Tendo idêntico objetivo em mente, } \\
\text { tivemos uma sessão de observação } \\
\text { visual e táctil, com desenho opcional } \\
\text { de materiais e objetos existentes na } \\
\text { sala de aula e usados pelas crianças } \\
\text { em suas atividades. Foi escolhido } \\
\text { então pelo grupo um dos materiais } \\
\text { observados - o papel - para que } \\
\text { fosse estudada sua função em } \\
\text { diferentes contextos, caminhando-se } \\
\text { nesta segunda etapa para o } \\
\text { exercício da flexibilidade adaptativa." }\end{array}$ & $\begin{array}{l}\text { A atenção direcionada às sensações advindas de } \\
\text { dois sistemas sensoriais (visual e somatosensorial) } \\
\text { reforça a possibilidade de associações a serem } \\
\text { registradas. Os eventos registrados a partir da } \\
\text { ativação de várias vias estão altamente conectados } \\
\text { e interligados. Portanto, deixam vários registros na } \\
\text { memória, o que facilitará sua evocação. Vale notar } \\
\text { a participação ativa do córtex frontal no que se } \\
\text { refere ao planejamento e à escolha da próxima } \\
\text { atividade. }\end{array}$ \\
\hline $\begin{array}{l}\text { "Primeiro fomos a uma fábrica de } \\
\text { papel, onde dois níveis dinâmicos } \\
\text { foram observados: o movimento das } \\
\text { máquinas e a dinâmica da } \\
\text { transformação do produto. Seguiu-se } \\
\text { uma visita a uma empresa editora, } \\
\text { onde as crianças observaram o uso } \\
\text { do papel, desde o desenho das } \\
\text { estórias em quadrinhos até o } \\
\text { processo de sua impressão gráfica. } \\
\text { Essa experiência teve como } \\
\text { resultado uma clara definição do } \\
\text { relativo valor do material, não só do } \\
\text { ponto de vista qualitativo, como } \\
\text { também do ponto de vista } \\
\text { quantitativo. As crianças, por } \\
\text { exemplo, descobriram que, enquanto } \\
\text { em uma fábrica o estrago de algumas } \\
\text { resmas de papel é insignificante, } \\
\text { numa editora, trezentas folhas de } \\
\text { papel de desenho que se estraguem } \\
\text { representam uma perda." }\end{array}$ & $\begin{array}{l}\text { Observar significa direcionar a atenção } \\
\text { voluntariamente; em toda ação voluntária, há a } \\
\text { participação do córtex frontal. Mas, o sistema } \\
\text { límbico (sistema responsável pelo processamento } \\
\text { emocional) não é desativado enquanto realizamos } \\
\text { tarefas cognitivas. Razão e emoção estão sempre } \\
\text { presentes, ainda que em proporções variadas, na } \\
\text { atividade encefálica. O processo de observar um } \\
\text { ciclo produtivo completo (da fabricação do papel até } \\
\text { a impressão gráfica) facilita a comparação dos } \\
\text { estágios de produção. Para que essa comparação } \\
\text { se concretize, é necessária a participação ativa de } \\
\text { vários sistemas integrados atuando } \\
\text { simultaneamente, entre eles: o hipocampo, o córtex } \\
\text { frontal, córtex entorrinal e o sistema límbico. }\end{array}$ \\
\hline $\begin{array}{l}\text { "De volta à escola, elas desenharam } \\
\text { suas próprias estórias em } \\
\text { quadrinhos, estimuladas } \\
\text { principalmente pelo fato observado } \\
\text { de que, salvo raras exceções, as } \\
\text { revistas em quadrinhos editadas no } \\
\text { Brasil são meras traduções de } \\
\text { revistas americanas. A estrutura da } \\
\text { linguagem da estória em quadrinhos } \\
\text { - ação em seqüência - deu } \\
\text { movimento ao esquema infantil. } \\
\text { Nessa experiência, os elementos } \\
\text { imaginativos foram manipulados em } \\
\text { alto grau, e acentuadas as diferentes } \\
\text { definições valorativas do objeto (no } \\
\text { caso, o papel)". }\end{array}$ & $\begin{array}{l}\text { Nesta atividade vários sistemas estão interagindo } \\
\text { de modo coordenado: o sistema sensorial, o } \\
\text { sistema motor, o córtex frontal, o sistema límbico e } \\
\text { áreas relacionadas a linguagem. Todos esses } \\
\text { sistemas estão sendo acionados a partir da atuação } \\
\text { da atenção voluntária. A atenção, a percepção e a } \\
\text { memória estão atuando de maneira integrada, } \\
\text { ativando a imaginação. Essa imaginação, quando } \\
\text { selecionada e devidamente registrada, apresenta- } \\
\text { se no resultado desse trabalho, que pode ser } \\
\text { considerado como um registro da manifestação da } \\
\text { individualidade. }\end{array}$ \\
\hline
\end{tabular}




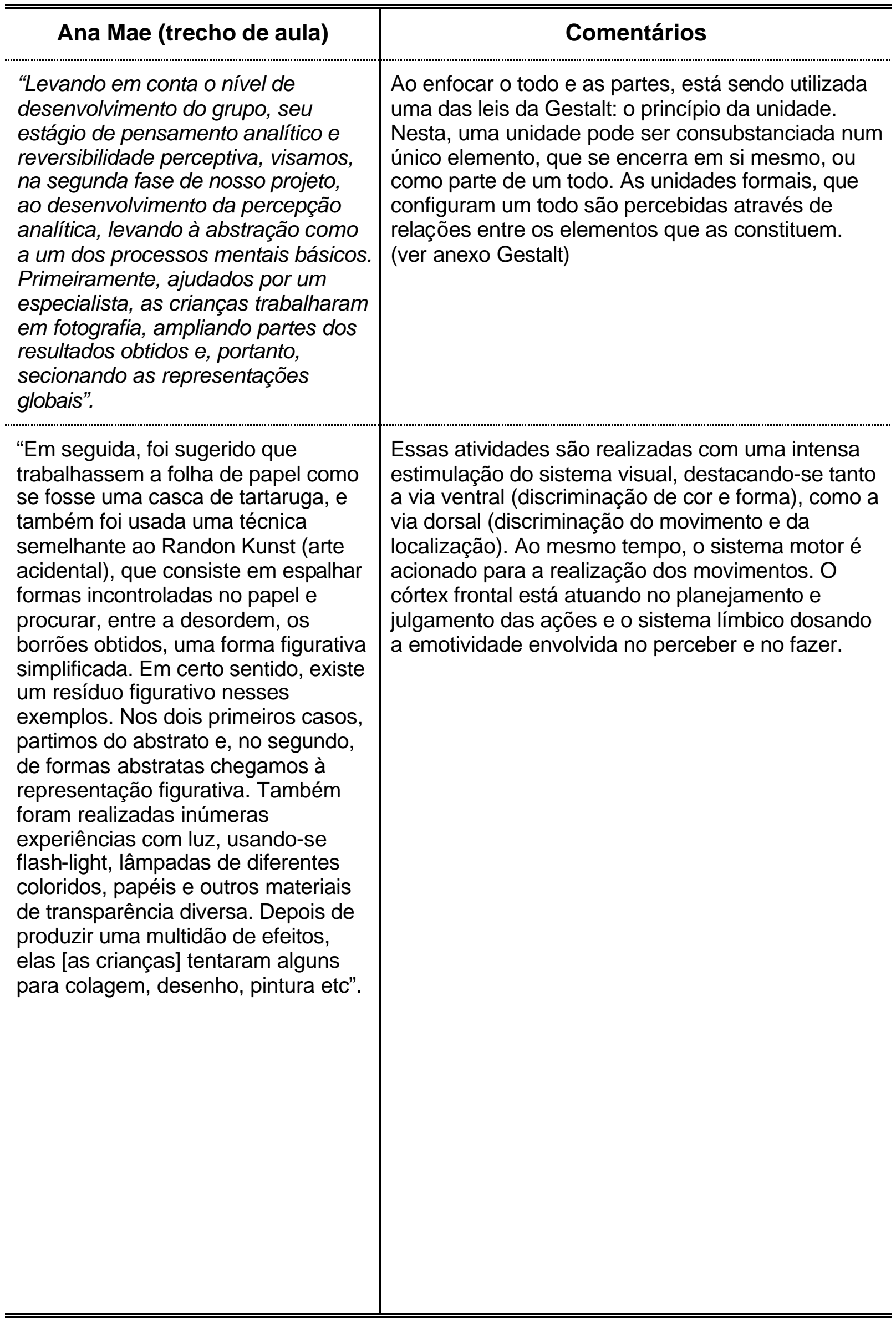




\begin{tabular}{|c|c|}
\hline Ana Mae (trecho de aula) & Comentários \\
\hline $\begin{array}{l}\text { "Em seguida, elas foram levadas a } \\
\text { uma experiência de análise mais } \\
\text { profunda, procurando abstrair os } \\
\text { objetos, retirando deles apenas } \\
\text { linhas e usando essas linhas em } \\
\text { novo contexto. Depois dessas } \\
\text { experiências, as crianças mudaram } \\
\text { sua atitude em relação ao trabalho } \\
\text { abstrato em arte. Antes elas agiam } \\
\text { como se a Arte abstrata fosse uma } \\
\text { espécie de nonsense ou jogo, em } \\
\text { lugar de trabalho. Quando tinham } \\
\text { preguiça, jogavam tinta sobre o papel } \\
\text { e diziam: "Isto é Arte Moderna". Para } \\
\text { elas, abstração era o mesmo que } \\
\text { jogar tintas, mas depois deste } \\
\text { programa, elas começaram a } \\
\text { respeitar a arte abstrata como uma } \\
\text { pesquisa." }\end{array}$ & $\begin{array}{l}\text { O físico Werner Heisenberg definiu abstração como } \\
\text { "a possibilidade de considerar um objeto ou grupo } \\
\text { de objetos de um ponto de vista ao mesmo tempo } \\
\text { em que desconsidera todas as outras propriedades } \\
\text { do objeto. A essência da abstração é escolher uma } \\
\text { característica que, em contraste com outras } \\
\text { propriedades, é considerada particularmente } \\
\text { importante". Essa definição pode ser aplicada a } \\
\text { qualquer disciplina. A atividade proposta } \\
\text { evidenciava a linguagem visual, portanto: } \\
\text { discriminação de bordas (V1), forma (IT), cor (V4), } \\
\text { movimento (MT ou V5), localização (de V1 por toda } \\
\text { via dorsal) serão enfocadas não apenas informando } \\
\text { a imagem do objeto observado, mas também } \\
\text { reconstruindo de outra forma. Cada um dos } \\
\text { elementos existentes da cena visual será focalizado } \\
\text { de forma preferencial, gerando novas possibilidades } \\
\text { de entendimento cognitivo e traduzindo esse } \\
\text { conhecimento em novas imagens. Na abstração } \\
\text { pictórica, além da intensificação da atividade } \\
\text { neuronal do sistema visual, é também necessário } \\
\text { uma ampla fluidez cognitiva que dê suporte para a } \\
\text { construção não habitual das imagens. }\end{array}$ \\
\hline
\end{tabular}

Observação: O quadro elaborado pela autora deste trabalho a partir de trechos das aulas de Ana Mae comentados.

Embora o relato se refira às atividades realizadas em 1971, ele continua atual e pertinente. As citações mais recentes do trabalho de Ana Mae Barbosa não contradizem suas citações anteriores, como, por exemplo, quando ela diz que:

Por meio da Arte é possível desenvolver a percepção e a imaginação, apreender a realidade do meio ambiente, desenvolver a capacidade crítica, permitindo ao indivíduo analisar a realidade percebida e desenvolver a criatividade de maneira a mudar a realidade que foi analisada (BARBOSA, 2003, p.18).

Esse tipo de comentário, que relaciona a experiência pedagógica com

o funcionamento do sistema nervoso, pode não ser agradável, mas não restringe 
nem retira da experiência em si, sua poesia. Apenas considera que toda ação humana parte de um alicerce neurofisiológico. A fisiologia do sistema nervoso pode ser considerada uma base, uma plataforma de lançamento, que dá sustentação neuronal à imaginação. E é com a imaginação que alçamos vôo e realizamos nossas viagens mais fantásticas.

A seguir encontram-se expostos vários desenhos de cavalos. Essas imagens foram selecionadas na internet de acordo com os seguintes critérios: pertencerem a épocas distintas, foram produzidas por pessoas de diferentes faixas etárias, com diferente formação profissional, independente do gênero.

Observe essas imagens. O que revelam esses desenhos de cavalos?
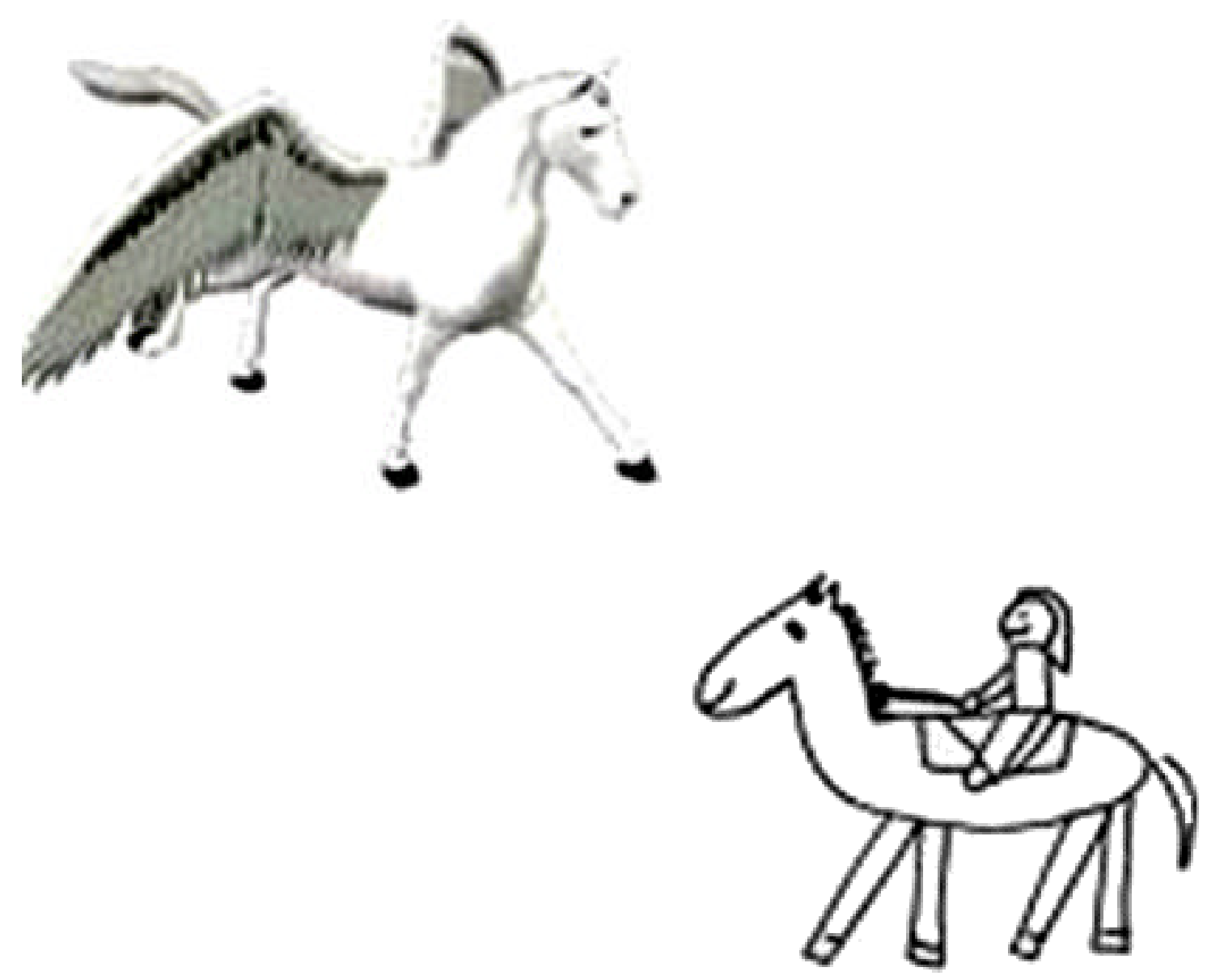

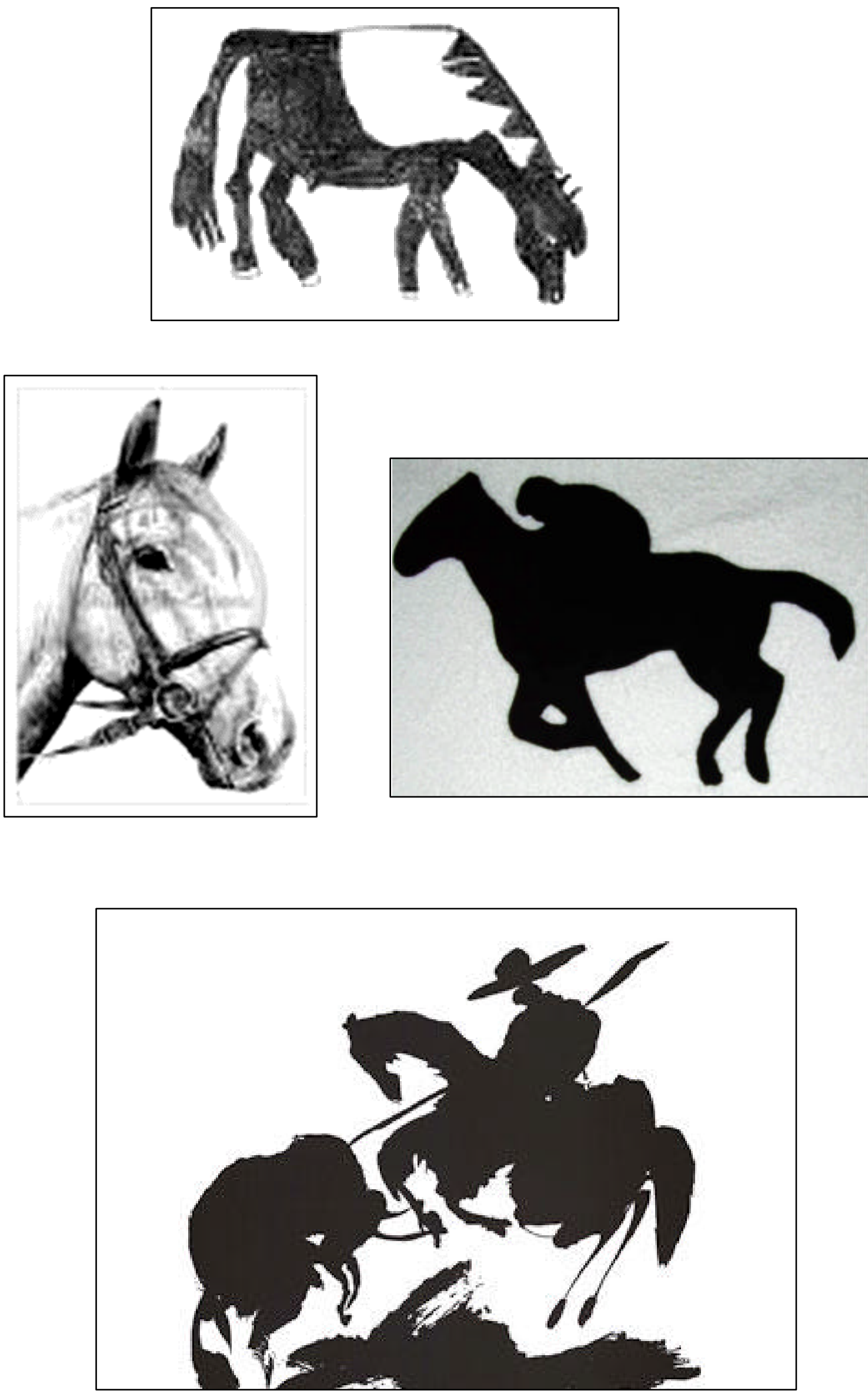

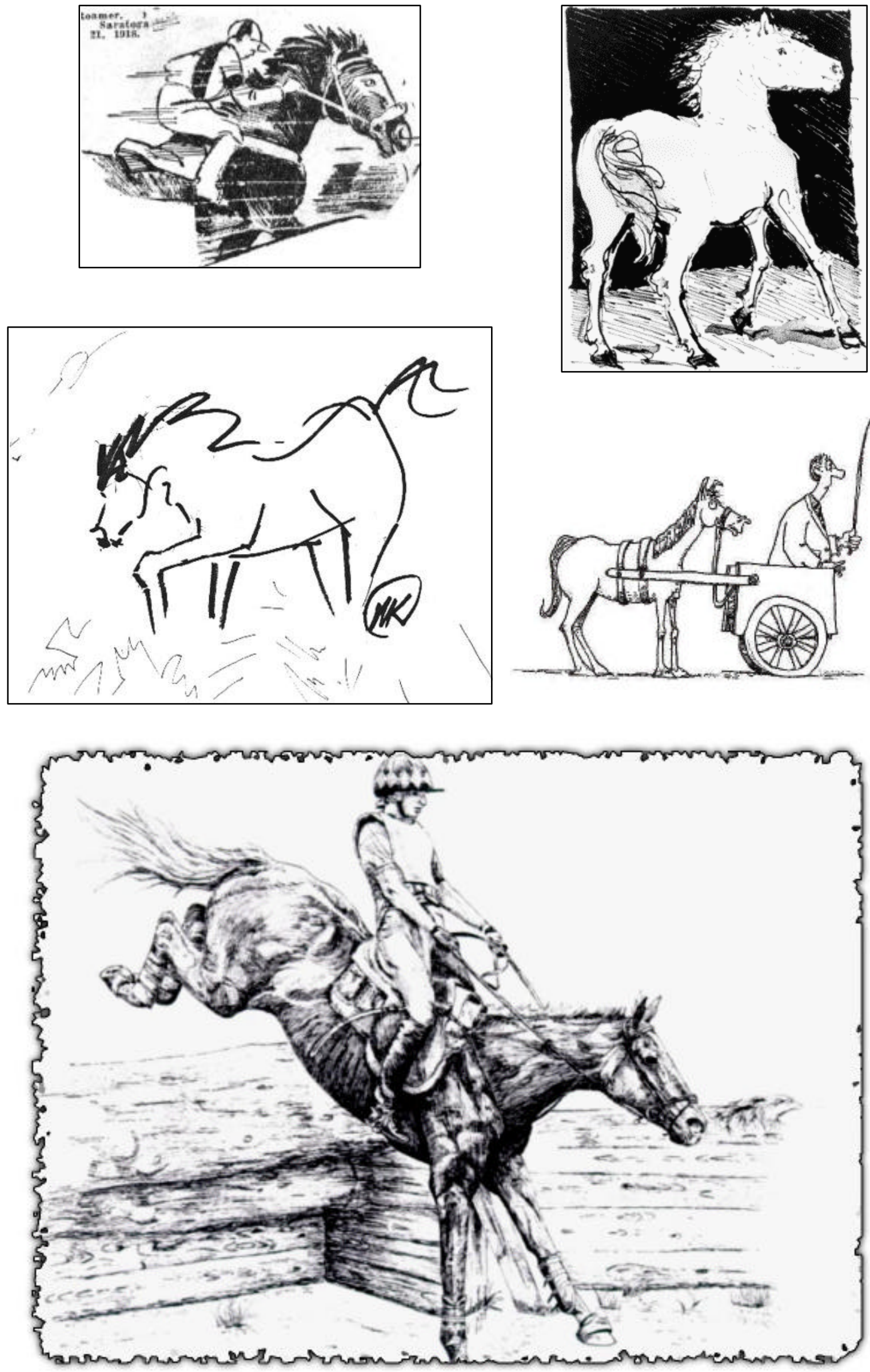
Cada desenho revela a individualidade de quem o desenhou, seu modo característico de se relacionar com o cavalo, o entorno ambiental, o entorno emocional, expectativas e sonhos. Esses desenhos, assim todos os outros, partem de uma realidade interna (referente ao autor) e externa (referente ao meio), expressam em seu traçado a imaginação de quem os criou, e ativam a imaginação de quem os observa.

Precisamos interpretar o que percebemos com a imaginação para criar compreensão. Toda ciência e toda a arte são demonstrações desse fato. O cavalo não é apenas um animal que pasta; que tem crina e rabo; que foi domesticado; que serve como meio de transporte; é também um animal de estimação, um parceiro nas batalhas e guerras; uma obra de arte... Pensar no cavalo de diversas maneiras faz com que ele seja percebido de diferentes maneiras. A fotografia, o desenho, a própria escrita, não passam de papel recoberto com um pouco de tinta ou sais de prata. O que fazemos com cada uma dessas coisas ocorre em nossa cabeça, de acordo com nossa capacidade de recriar as sensações, as emoções e as percepções do que elas devem simbolizar. Seus significados são ficções inventadas que só têm um halo de verdade se estiverem conectadas ao que consideramos verdadeiro por experiência vivencial. O pensamento produtivo ocorre quando a imaginação interna e a experiência externa coincidem, e é a partir daí que construímos o que percebemos como sendo a realidade.

Ler um romance, olhar uma escultura ou ouvir uma peça musical como se fossem apenas objetos _'algo' a ser analisado _ é perceber somente a llusão. A Realidade só pode ser vivenciada quando entendemos que a arte nasce da vida e se relaciona com ela. Há mais de sessenta anos, o filósofo de educação John Dewey afirmou em seu clássico 'Art as Experience' que a educação artística 
convencional falha exatamente da mesma forma que a educação científica _ por ocultar, em vez de revelar, as ligações entre a teoria e a prática. Para Dewey, quanto mais considerarmos os objetos artísticos distintos da experiência original que os fez surgir, tanto mais isolamos a arte num reino separado e a ameaçamos com a irrelevância. Desse modo, as 'formas refinadas e intensificadas da experiência que são as obras de arte' desconectadas dos 'eventos, das ações e dos sofrimentos do cotidiano que são universalmente reconhecidos como elementos constituintes da experiência' (ROOTBERNSTEIN, 2001, p. 31).

O que parece um simples desenho feito por alguém habilidoso tem como suporte um trabalho cognitivo de fundamental importância para o ser humano. O ensino e a aprendizagem da arte possibilita que a construção de perceptos seja significativa em quantidade e qualidade, estabelecendo um maior número de conexões na formação de memórias. Essas, quando evocadas, fornecem um repertório mnemônico com o qual formulamos nossas ações e interagimos com o meio que nos cerca. A imaginação fornece o tempero deste processo, ela poderá tornar esse "prato" uma iguaria sem precedentes ou um "prato" insosso, sem qualquer atrativo. 


\section{PESQUISAS}

\subsection{Neurociência e educação}

A Neurociência tornourse uma das mais prósperas áreas de pesquisa multidisciplinar dos nossos tempos. O objetivo da neurociência é compreender os processos mentais pelos quais percebemos, agimos, aprendemos e nos lembramos. Busca explicar o comportamento em termos das atividades neurais, e como o sistema nervoso organiza suas milhões de células nervosas individuais para gerar o comportamento.

De um modo esquemático, podem-se considerar seis grandes disciplinas que a constituem: a neurobiologia molecular, que tem como objeto de estudo as diversas moléculas de importância funcional no sistema nervoso; a neurobiologia celular, que aborda as células que formam o sistema nervoso, sua estrutura e função; a neurofisiologia, que considera populações de células nervosas situadas em diversas regiões do sistema nervoso, que constituem sistemas funcionais; a neuroanatomia, que realiza uma abordagem dos sistemas funcionais, focalizando os aspectos morfológicos; a neurociência comportamental ou psicofisiologia, que se dedica a estudar as estruturas neurais que produzem comportamentos como o sono, os comportamentos sexuais, emocionais, etc; e, finalmente, a neurociência cognitiva, que trata das capacidades mentais mais complexas, geralmente típicas do homem, como a linguagem, a autoconsciência, a memória, etc. Os limites entre essas disciplinas não são nítidos, portanto é preciso saltar de uma para a outra sempre que se tentar compreender o funcionamento do sistema nervoso. 
Com avanços significativos em vários campos, o estudo do encéfalo tem atraído profissionais de diversas áreas, como físicos, engenheiros, matemáticos, fisioterapeutas, fonoaudiólogos, biólogos, psicólogos e demais profissionais envolvidos com medicina e pesquisas biomédicas.

Esse engajamento multidisciplinar foi uma conseqüência natural da tomada de consciência de que, para entender algo tão complexo como o encéfalo, é necessário usar a criatividade e a observação a partir de vários ângulos do saber, a capacidade de diálogo permanente entre diferentes pontos de vista, a seriedade e a competência profissional aliada à aplicação de tecnologias de ponta.

As pesquisas neurocientíficas estão apenas começando a encontrar aplicação no campo do aprendizado. A aproximação entre neurociência e educação cria uma maior probabilidade de que descobertas valiosas possam ser utilizadas mais rápida e apropriadamente no campo educacional.

Alguns passos nesta direção foram dados pela Organização de Cooperação e Desenvolvimento Econômicos (OCDE), que lançou em 1999 o projeto "Ciência da Aprendizagem e Pesquisa do Cérebro". O objetivo desse projeto é estimular a colaboração entre as ciências da aprendizagem e a pesquisa neurocientífica, assim como entre pesquisadores e promotores de políticas públicas.

A partir dos fóruns realizados pela OCDE, respectivamente, em Nova York, em junho de 2000; em Granada, em fevereiro de 2001; e em Tóquio, em abril de 2001; foram obtidas significativas conclusões que emergiram de intensos debates entre neurocientistas, psicólogos, educadores, profissionais da saúde e políticos. Dentre as questões de caráter geral, desenvolvidas com o apoio da OCDE, também estão pesquisas sobre a aprendizagem permanente e função cerebral em relação a: nutrição, sono, consumo de drogas, administração do estresse, exercício físico e 
controle emocional. Este projeto continua em desenvolvimento e é possível se manter atualizado através do site oficial da OCDE.

\subsubsection{Aprendizado e neurociência}

Como as pessoas aprendem? O que acontece no cérebro quando adquirimos conhecimentos, habilidades ou atitudes? Essas questões interessam aos homens há séculos. Hoje, os cientistas estão começando a entender como o cérebro jovem se desenvolve e como o cérebro maduro aprende. A neurociência, entre outras disciplinas, vem contribuindo para o avanço desse conhecimento.

O termo cognição quer dizer, literalmente, "conhecimento". Neurocientistas cognitivos estudam a natureza do pensamento, da linguagem, da memória, da emoção e da motivação. Este estudo é delicado, pois esses processos mentais não podem ser vistos. Eles só podem ser deduzidos a partir do comportamento.

A suposição de uma base neurológica para as construções cognitivas possui riscos, mas isso não quer dizer que não deva ser pesquisada. A cognição implica na habilidade de responder a estímulos, sejam externos ou internos, identificá-los e planejar respostas significativas para eles. Se tomarmos, por exemplo, que embora as pessoas falem sobre memória como uma coisa unitária, no funcionamento encefálico a construção da memória não se revela unitária em nada. Esta se apresenta de diferentes formas, utilizando lógica distinta e diferentes circuitos no encéfalo, que partem basicamente da sinalização neuronal.

Para colaborar nas pesquisas realizadas nesta área, fornecendo mais elementos que possam ser analisados como dados, conta-se com o 
desenvolvimento de novas tecnologias. Técnicas como a neuroimagem funcional, que inclui tanto a ressonância magnética funcional (RMf), a tomografia por emissão de pósitrons (PET), aliadas à espectroscopia no infravermelho próximo (NIR), entre outras, que estão permitindo aos cientistas compreender, com maior clareza, o funcionamento do encéfalo e a natureza da mente.

\subsubsection{Cooperação entre as áreas}

Embora conhecimentos e resultados valiosos já estejam disponíveis, pode levar anos para que as descobertas dessa nova ciência possam ser pronta e seguramente aplicadas na educação. O avanço, porém, será mais rápido se as várias disciplinas que compõem a área da aprendizagem se comunicarem e cooperarem.

É natural haver problemas de comunicação entre diferentes áreas. Neurocientistas, psicólogos, educadores e artistas são comunidades que não compartilham um vocabulário profissional comum, aplicam diferentes métodos e lógicas, exploram diferentes questões, perseguem objetivos diferentes. Só a consciência dessas diferenças culturais e o convívio é que podem reduzir os préconceitos e promover o entendimento destes setores. Esse é o desafio de uma equipe multidisciplinar. Uma das dificuldades a ser enfrentada é a falta de uma linguagem comum entre as diversas disciplinas que trabalham com 0 aspecto cognitivo. Termos como plasticidade, inteligência e estimulação constituem um exemplo. A esses, seria fácil acrescentar uma longa lista: habilidade, atitude, controle, desenvolvimento, emoção, imitação, capacidade, aprendizagem, memória, mente, natureza, criação, criatividade entre outras. 
A título de exemplo, temos que plasticidade e periodicidade são termos que precisam ser entendidos de maneira que um não exclua o outro. $O$ senso comum e a neurociência confirmam que nosso cérebro é plástico; continua a desenvolver-se, a aprender e mudar, até a senilidade ou a morte. Portanto, a idéia de educação permanente faz sentido. Nunca é tarde para aprender; desde que o aprendiz tenha confiança, auto-estima e motivação.

No entanto, existem períodos receptivos, espécie de janelas de oportunidade, quando o cérebro fica particularmente receptivo a certos estímulos e muito apto a aprender. Um exemplo óbvio é a extraordinária velocidade com que as crianças aprendem sua primeira língua. Todas as crianças, a não ser as portadoras de grave deficiência, fazem isso praticamente no mesmo tempo em qualquer parte do mundo, mesmo que depois venham a ser classificadas como alunos rápidos ou lerdos, inteligentes ou fracos, de sucesso ou fracasso. Também podem existir períodos receptivos para aprender uma segunda língua, desenvolver a linguagem musical, teatral, visuoespacial e expressiva, adquirir habilidades sociais, como o trabalho em equipe, e até mesmo optar entre ser um aprendiz competente ou dependente.

A neurociência cognitiva também ajuda a compreender a distinção entre nossas diferenças individuais e o que é comum a todos os cérebros. Homens e mulheres, por exemplo, parecem usar o cérebro de forma diferenciada, mas não se sabe, ao certo, quais as implicações disso. Há diferenças significativas de amadurecimento entre o encéfalo de uma criança, de um adolescente e de um adulto. Já são suficientes as evidências demonstrando que a educação e o entorno emocional esculpem o encéfalo e modificam sua forma de processar as informações. 
Naturalmente, os cientistas são cautelosos, em especial na divulgação de suas conclusões em um campo tão sensível quanto o encéfalo humano. É conveniente que se estabeleça a distinção entre:

- o que está comprovado (a plasticidade do encéfalo);

- o que é provável (períodos receptivos);

- o que se tornou especulação inteligente (as implicações de gênero);

- o que se tornou uma série de concepções errôneas ou simplificações manipuladas pela mídia (a função dos hemisférios direito e esquerdo).

Parece provável que, nos próximos anos, a neurociência cognitiva venha a oferecer respostas confiáveis a importantes questões sobre a aprendizagem humana, tais como:

- Qual o ambiente e o programa mais adequados à aprendizagem das crianças pequenas? É aconselhável oferecer a elas um treinamento intensivo em alfabetização e matemática elementar?

- Quais os períodos mais receptivos no desenvolvimento do cérebro? Que implicações eles têm para um currículo de aprendizagem relacionado à idade?

- Por que algumas crianças apresentam extrema dificuldade na alfabetização e no aprendizado da matemática? $O$ que se pode fazer para prevenir ou remediar problemas como dislexia ou acalculia?

- Quais os limites do cérebro humano? É possível a qualquer pessoa igualar o desempenho de um Mozart ou um Einstein, com boa educação no ambiente correto? 
- O que significa desaprender? Como se pode corrigir, eficazmente, maus hábitos, incompetências ou concepções errôneas?

- Qual o papel da emoção na aprendizagem? Como facilitar a cooperação entre sistema límbico (emocional) e córtex cerebral (cognitivo) diante do desafio da aprendizagem?

- Quais regiões do encéfalo são predominantemente desenvolvidas ao executar atividades artísticas?

- Qual o período receptivo ideal para o desenvolvimento da linguagem visuoespacial?

\subsubsection{Implicações educacionais}

A compreensão das vantagens e limitações das tecnologias do imageamento encefálico, assim como a necessidade de conduzir rigorosos protocolos cognitivos, é uma etapa importante para se entender como a neurociência cognitiva poderá fornecer dados para a elaboração de currículos escolares, que estejam apoiados na atividade encefálica. Será preciso mesclar pesquisas do campo da psicologia, da neurociência e da educação em geral; para produzir uma nova geração de pesquisadores e educadores capazes de analisar questões significativas, tanto na área educacional com científica.

Mas, existem limites quanto ao tipo de temas a serem pesquisados no momento, pois os atuais métodos de pesquisa neurocientífica restringem necessariamente os tipos de questões com possibilidades de serem pesquisadas. As perguntas do tipo "Como os indivíduos aprendem a reconhecer palavras escritas?" são possíveis de serem respondidas com o atual conhecimento 
da neurociência. Porém, a questão 'Como os indivíduos comparam os temas de diferentes histórias?' é bem mais complexa de ser respondida atualmente.

Isso ocorre porque a primeira pergunta nos remete a estudos em que os estímulos e reações podem ser mais facilmente controlados e comparados aos de outra tarefa. A segunda pergunta envolve muitos fatores que não podem ser separados durante a experimentação. Por essa razão, as tarefas educacionais que os educadores gostariam de ter respondidas continuarão sendo alvo de amplas pesquisas multidisciplinares, por apresentarem múltiplas variáveis, tornando-se assim mais complexas do que aquelas que podem ser convenientes à neurociência cognitiva.

Os pesquisadores também enfatizam a necessidade metodológica de testar o aprendizado não apenas depois de alguma intervenção educativa (que se costuma fazer), mas também posteriormente, a intervalos, em especial no caso de comparações relativas à idade. Esses estudos longitudinais tiram os projetos de pesquisa do laboratório e os insere em situações da vida real, o que dificulta saber quando os resultados poderão ser interpretados e colocados à disposição da educação.

$\mathrm{Na}$ análise de dados científicos, é importante manter padrões críticos ao julgar as afirmações sobre a neurociência cognitiva e suas implicações para a educação. Alguns pontos sempre devem ser considerados, como:

- O estudo original e seus primeiros objetivos.

- Quando se trata de um único estudo ou de uma série deles.

- Se o estudo teve um resultado na aprendizagem.

- A população pesquisada. 
É importante enfatizar a importância de se adquirir uma condição crítica e esclarecida para analisar os resultados fornecidos nas descobertas científicas. É necessário desenvolver um julgamento crítico das alegações sobre aprendizagem e ensino com base em pesquisas do funcionamento do sistema nervoso.

Teremos melhores condições de chegar a adequados currículos, baseados na atividade do sistema nervoso, se forem aceitos os seguintes princípios:

- A popularidade de uma alegação neurocientífica não significa, necessariamente, que ela seja válida;

- A aprendizagem não está totalmente sujeita ao controle da consciência ou da vontade;

- A metodologia e a tecnologia da neurociência cognitiva estão ainda em formação;

- O sistema nervoso, em especial o encéfalo, passa por mudanças naturais de desenvolvimento durante a vida;

- Muitas pesquisas da neurociência têm buscado compreender ou resolver patologias ou doenças relacionadas com o encéfalo;

- Uma ciência satisfatória da aprendizagem deve considerar fatores emocionais e sociais, além dos cognitivos.

Os dados da neurociência cognitiva, aliados ao conhecimento das áreas educacionais específicas pesquisadas, podem ajudar a refinar as hipóteses, eliminar as ambigüidades e apontar direções para as pesquisas sempre mais abrangentes. Enfim, transpor com maior facilidade a distância entre o laboratório e o sistema de ensino. 


\subsection{Pesquisas relacionadas com arte e neurociência}

Embora seja extremamente antiga e persistente a presença de manifestações artísticas nas sociedades humanas, como pintura, escultura, desenho, música, dança, entre outros, apenas recentemente os cientistas dirigiram seus esforços, de uma maneira mais sistemática, no sentido da investigação dos mecanismos neurobiológicos subjacentes à complexa e sofisticada capacidade cognitiva referente à produção da arte e da apreciação estética.

As razões para que essas pesquisas só estejam sendo realizadas recentemente referem-se à inexistência anterior, tanto de teorias abrangentes capazes de dar conta da complexidade do funcionamento cerebral quanto de tecnologia adequada para esse tipo de investigação científica.

A percepção e a cognição humana apresentam um estágio de complexas construções de atividades neurofisiológicas enquanto o indivíduo está realizando uma ação artística. Assim, as pesquisas que estão investigando os processos mentais envolvidos na dança, na música, nas artes visuais e na apreciação estética, tanto podem fornecer dados para compreensão da cognição humana como subsídios para arte educadores.

Abaixo estão relacionados artigos, que se encontram à disposição na internet, de cientistas renomados que têm desenvolvido pesquisas relacionadas à percepção humana; aos processos cognitivos e à função da estética no organismo. Sempre é bom lembrar que a maioria dos artigos são escritos por neurocientistas, que embora tenham afinidade e simpatia pelo campo da arte, apresentam limitada vivência com a ação artística. Portanto, é bom ler com paciência para não correr o risco de rejeitar o artigo na íntegra, caso não concorde com algumas considerações 
sobre a função e o significado da arte.

Algumas pesquisas realizadas na área de estética e percepção:

The science of art: A neurological theory of aesthetic experience (1999)

Vilayanur Ramachandran e William Hirstein - Center for Brain and Cognition, University of California, San Diego, La Jolla, USA.

Neste artigo, os autores sugerem oito princípios universais referentes a percepção e apreciação estética da arte. As leis destacadas são: Enhancement of features that deviate from average, Grouping of related features, Isolation of a particular visual clue, Contrasting of segregated features, Dislike of unnatural perspectives, Perceptual problem solving or deciphering ambiguous scenes, Metaphor, Symmetry.

Eles partem de uma sólida base neurofisiológica e levantam interessantes questões, porém a pouca vivência com a ação artística acabou gerando acaloradas discussões entre a comunidade artística.

\section{Art and the Brain}

Semir Zeki - Department of Cognitive Neurology, University College, London.

Este artigo analisa o sistema visual e sua participação no processo cognitivo, buscando relacioná-los com o que considera ser a função da arte e apreciação estética. $\mathrm{O}$ autor tem renome internacional, um vasto trabalho em neurobiologia e apreciação estética; vêm contribuindo enormemente para o avanço das pesquisas nesse setor. $\mathrm{O}$ artigo cita vários artistas e suas obras usando uma linguagem clara e acessível. 


\section{$\underline{\text { The artist like a neuroscientist }}$}

Patrick Cavanahag - Vision Sciences Laboratory, Departament of Psychology, Haward, USA.

O artigo faz a análise de diversas pinturas considerando como os artistas se utilizam de técnicas para conseguir determinados efeitos de reflexos, coloração, sombras e contornos; independente dos conceitos da física. Do resultado desta comparação, Cavanahag considera a possibilidade de obter dados para avaliar a fisiologia do sistema visual a partir da análise pictórica de quadros disponíveis nos museus a séculos.

\section{Luminance and night vision - Cap. 3}

Margaret Livingstone - Professor of neurobiology, Haward Medical School.

Este é um capítulo de um livro à disposição na internet. A autora é uma cientista de destaque na área da visão, ela analisa o processo neurofisiológico da visão com exemplos retirados dos quadros de Picasso, Monet, e outros artistas. Para melhor entendimento, é bom um conhecimento prévio do funcionamento do sistema visual.

Existem muitas pesquisas relacionando música e neurociência, algumas já trazem importantes resultados que poderão ser usados na educação em geral, na musicoterapia e na neurociência cognitiva. Outras tantas estão em andamento. Muitas vezes é possível considerar os resultados já apresentados nesta área e inferir possibilidades a serem pesquisadas nas artes plásticas. 
Cérebro, música, cognição: variações sobre um tema inesgotável.

Cláudio Guimarães dos Santos - é médico e neurocientista da Universidade Federal de São Paulo; trabalha na reabilitação de pacientes com disfunções cognitivas.

Este trabalho traça um percurso relacionando a linguagem musical com a linguagem verbal e considera a especialização dos hemisférios cerebrais. Ao utilizar uma linguagem também apropriada para leigos, o texto se torna bastante sugestivo e aguça no leitor a vontade de se aprofundar nos temas apresentados.

\section{Music, the food of neuroscience?}

Robert Zatorre - Cognitive Neuroscientist, Montreal Neurological Institute; James McGill - Professor of neurosciense, Montreal Neurological Institute.

Neste artigo os autores fazem considerações sobre as áreas corticais e sistemas neurofisiológicos envolvidas ao tocar, ouvir e criar músicas. Essas atividades envolvem praticamente todas as funções cognitivas. Zatorre procura explicar como a música poderia dar subsídios neurocientíficos para compreensão do discurso verbal, da plasticidade neuronal e até eventualmente suposições sobre a origem das emoções.

One year of musical training affects development of auditory corticalevoked fields in young children.

Laurel Trainor - Professor na Universidade McMaster, Canadá.

Este artigo apresenta o resultado da pesquisa avaliando o desempenho cerebral de crianças com quatro a seis anos de idade, submetidas a lições musicais pelo método Suzuki, criado pelo pedagogo japonês Shinichi Suzuki (1898-1998). 
Esse desempenho mostrou ser superior quando comparado a pessoas sem treinamento especial.

$\mathrm{Na}$ área da dança, pesquisas apontam as relações existentes entre o sistema motor, sistema sensorial, apreciação estética e a importância dos neurônios espelhos.

\section{The dancing brain.}

Ivar Hagendoorn - Filósofo, coreógrafo de formação não acadêmica, fotógrafo.

Esse artigo procura relacionar a apreciação estética da apresentação de um ballet com aspectos neurofisiológicos do funcionamento do sistema nervoso.

Some speculative hypotheses about the nature and perception of dance and choreography.

Ivar Hagendoorn - Filósofo, coreógrafo de formação não acadêmica, fotógrafo.

Continuando a desenvolver o tema do artigo citado acima, o autor aprofunda sua investigação, fornecendo um trabalho mais sedimentado na literatura científica.

\section{$\underline{\text { Reflexo Revelador }}$}

David Dobbs - escreve sobre ciência, medicina e cultura. É colaborador da Scientific American Mind e do New York Times Magazine.

Esta reportagem foi publicada na revista Mente \& Cérebro ano XVI, no 161, junho 2006. Com uma linguagem própria para o público leigo, aborda a questão dos neurônios-espelho, suas funções e implicações cognitivas. A compreensão destas questões é fundamental para todas as áreas de expressão a rtística. 
The human mirror neuron system: A link between action observation and social skills.

Lindsay M. Oberman, Jaime A. Pinedo - Center for Brain and Cognition, University of California, San Diego, La Jolla, USA.

Neste artigo os autores apresentam o resultado da pesquisa, na qual avaliaram a ação do sistema neurônios-espelho (MNS), não apenas no processamento de atividades motoras como também nas atividades que apresentam relevâncias sociais. A linguagem é clara, simples e direta, permitindo que o leitorleigo tenha possibilidade de saber como se realiza uma pesquisa nesta área. 


\section{CONSIDERAÇÕES FINAIS}

"Chegar ao fim é construir um começo. O fim é o lugar de onde partimos". T. S. Eliot

Uma vez num Congresso de Arte Terapia realizado em Porto Alegre, Ana Mae Barbosa disse: "O ensino e a aprendizagem da arte é um caminho para recuperar o que há de humano no ser humano". Na ocasião essa frase teve um grande impacto sobre mim, a ponto de ser um dos motivadores da escolha dessa dissertação. Hoje após passar por todo processo do mestrado observo o quanto essa frase é exata. E tem clara sustentação na própria história da evolução da espécie humana.

Quando buscamos entender o modo como adquirimos conhecimentos, e como isso acontece no nível celular, naturalmente somos levados a considerar a evolução da espécie humana. Como foi dito anteriormente nesse trabalho, a característica que nos distingue de outras espécies e que nos torna humanos é a capacidade de realizar processos cognitivos simbólicos. O marco evolutivo de nossa espécie é a aquisição e manipulação da linguagem por meio de símbolos, o que diz respeito também a arte, que não é outra coisa a não ser uma forma de linguagem. Portanto, podemos considerar que arte e cognição estão intrinsecamente ligadas.

Arte é um fenômeno cultural, recorrente no mínimo a cerca de 50.000 anos. É uma manifestação essencial para a humanização da espécie Homo sapiens, cujo aparecimento é concomitante a época em que nos tornamos humanos.

O ser humano ao realizar uma ação artística utiliza bilhões de neurônios, milhares de músculos, requesita a ação de todo sistema sensorial e toda sua 
capacidade de memória. Todos esses sistemas passam a trabalhar como uma orquestra regida pelo sistema atencional, que por sua vez foi ativado a partir de uma intenção. São bilhões de neurônios, espalhados por todas as regiões do encéfalo, que trabalhando em harmonia irão produzir um resultado de uma complexidade incontestável. Além dos processos descritos acima, precisamos considerar que os sistemas neurofisiológicos citados não se formaram em uma semana ou um ano, eles são o resultado de um processo evolutivo de milhares de anos. Conhecer e poder visualizar as etapas neurofisiológicas envolvidas em uma ação artística é simplesmente fantástico.

O estudo da neurociência me possibilitou vislumbrar de outra maneira o alcance e a importância da arte na vida das pessoas, ou seja qual a atuação da ação artística no funcionamento do organismo.

Muitas vezes as pessoas, em geral, por não terem tido uma experiência significativa com a ação artística e a correspondente construção desse conhecimento, formam uma visão deturpada do significado e importância desta ação. E porisso consideram a arte apenas como objeto de museu ou fruto de uma ação acidental e aleatória separada da vida, o que é um equívoco. Esse equívoco restringe, quando não impossibilita o reconhecimento da importância e do significado que a arte exerce na edificação de uma civilização.

Em consequência disso, cabe em grande parte aos arte educadores, serem capazes de mostrar a necessidade e importância do ensino e aprendizagem da arte, ao meio que os cerca. Ao traçar a trajetória evolutiva da espécie humana e associar o funcionamento do encéfalo, busquei evidenciar a presença da arte nesse processo. Sendo a arte uma expressão de vital importância para todo e qualquer ser humano, podemos perfeitamente entrever a importância do ensino e da 
aprendizagem da arte, embora ainda não tenhamos como comprová-lo com resultados científicos.

Assim procurei acrescentar alguns elementos de reflexão, que contribuissem para a formação de uma concepção ampla sobre a importância que um arte educador tem ao exercer o seu ofício.

Se o arte educador percebe a importância da ação artística no processo cognitivo e tem argumentos fundamentados em pesquisas arqueológicas e neurocientíficas sobre a recorrência da arte na evolução humana, nunca mais será o último a se manifestar e o último a ser reconhecido numa reunião pedagógica.

Esse foi o ângulo de visão considerado ao realizar esse trabalho. Procurei tornar viável um diálogo entre o ensino e aprendizagem da arte e a neurociência. Um diálogo pressupõe uma troca produtiva de experiências, vivências e resultados. Não se trata simplesmente de escrever sobre o assunto consernente a essas duas áreas do conhecimento. Para estabelecer essa conversa entre duas áreas tão distintas, algumas vezes me coloquei como tradutora intérprete de conceitos, em outras busquei salientar os pontos que lhes são comuns entre elas, os pontos de conflito, ou mesmo os sempre fascinantes pontos complementares.

Após várias tentativas, considerei que os arte educadores entenderiam melhor esse trabalho se eu partisse de uma visão geral sobre o funcionamento do sistema nervoso, abordando temas como a emoção e a imaginação. Deste modo o sistema nervoso, os neurônios, a percepção e os outros temas não foram aqui descritos segundo meras transcrições dos livros ou artigos neurocientíficos. Sempre que possível procurei apresentá-los inseridos no mundo da arte e fazendo referências ao ensino e a aprendizagem. 
Acredito que valendo-se de associações e analogias, o leitor será capaz de enriquecer substancialmente esse texto e gerar para si uma visão mais abrangente da maneira como o organismo, o ser humano e sua respectiva ação artística se articulam para construir uma civilização.

A vida em um organismo se manifesta a partir da interação deste com o meio que o cerca. A morte acontece quando essas trocas deixam de ser efetivas. Assim também o ser humano ao se relacionar com o ambiente capta sensações, dirige sua atenção de diversas maneiras e constrói perceptos. Esses perceptos carregam os significados que em si foram impressos e passam a ser ordenados e armazenados na memória. E no ato contínuo da vida, o ser humano utilizando o processo aqui descrito formula e reformula-se sempre em novas ações. Esse é o processo comum inerente a todas as pessoas independente da raça, cor, idade ou crença religiosa. Porém é possível acrescentar algo mais a esse processo. Esse algo a mais, abrangente e profícuo, é acrescentado por meio do contato com a arte.

Talvez já esteja próximo o tempo em que se possa também demonstrar, com base no conhecimento neurocientífico, aquilo que mentes brilhantes como John Dewey, Herbert Read, Viktor Lowenfeld, Elliot Eisner, Ana Mae Barbosa, entre outros, argumentam: Como a arte e o ensino e aprendizagem da arte são essenciais ao desenvolvimento do ser humano.

Uma questão como essa, há alguns anos atrás, só poderia ser investigada através da prática filosófica. Afinal, técnicas como a neuroimagem funcional não haviam sido criadas, a neurociência cognitiva ainda engatinhava e os neurôniosespelho não haviam sido descobertos.

Nos dias de hoje, com o avanço tecnológico e o resultado de pesquisas sobre a psicofisiologia da memória, da percepção e da atenção (três faculdades mentais 
essenciais para a realização da ação artística), já é viável imaginar pesquisas que venham a investigar a seguinte hipótese: Se a toda ação realizada pelo ser humano corresponde um correlato neuronal próprio, então, deve existir um correlato neuronal que seja próprio de uma ação artística.

Mas por enquanto isso é apenas hipótese, algo que podemos apenas imaginar e desejar. Do mesmo modo que um dia o homem já imaginou e desejou viajar pelo espaço e colocar os pés na lua. 


\section{REFERÊNCIAS BIBLIOGRÁFICAS}

ACILLOTTI, Jean-Pierre. Art et psychologie de la perception. Palais des Congrès de Grasse, 26 février 2004.

ALEXANDER, Guerda. Eutonia, um caminho para a percepção corporal. São Paulo: Martins Fontes, 1983.

AMATO, Ivan. Super vision: a new view of nature. New York: Abrans, 2003.

ARAÚJO-JORGE, Tânia C. (org.). Ciência e arte: encontros e sintonias. Rio de Janeiro: Senac, 2004.

ARBIB, Michael. From monkey-like action recognition to human language: an evolutionary framework for neurolinguistics. Behavioral and Brain Sciences, vol. 28, 2005. p. 105-167.

ARNHEIM, Rudolf. Arte e percepção visual; uma psicologia da visão criadora. São Paulo: EDUSP, 1980.

. Intuição e intelecto na arte. São Paulo: Editora Martins Fontes,

1989.

O poder do centro. Lisboa: Edições 70, 1988.

. The split and the structure. Uiversity of California Press,

London, 1996.

AZAR, Beth. How mimicry began culture. Monitor on Psychology, vol. 36, $n^{\circ} 9$, out., 2005. p. 54-57.

AZEVEDO, Fernando A. G. Movimento Escolinhas de Arte: em cena memórias de Noemia Varela e Ana Mae Barbosa. São Paulo, Dissertação de Mestrado, ECA/USP, 2000. p166 
BALDO, M.V; HADDAD, H. llusões: o olho mágico da percepção. Rev. Bras. Psiquiatr. 2003; 25 ( Supl II): 6- 11.

BARBOSA, Ana Mae (org.). Inquietações e mudanças no ensino da arte. São Paulo: Cortez, 2003.

. A Imagem no ensino da Arte. São Paulo: Perspectiva, 1986.

Arte: educação leitura no subsolo. São Paulo: Cortez Editora, 2001.

Arte: educação no Brasil. São Paulo: Editora Perspectiva, 2002.

Arte: Educação: Conflitos / Acertos. São Paulo: Max Limonad Ltda., 1984.

História da arte: educação. São Paulo: Editora Max Limonad, 1986.

. Recorte e Colagem: Influências de John Dewey no Ensino da Arte no Brasil. São Paulo: Cortez, 1982.

Teoria e prática da educação artística. São Paulo: Editora Cultrix, 1975.

BBC - SCIENCE \& NATURE. The day we learned to think: programme transcript. London: February 2006.

BEAR, F. Mark; CONNORS, W. Barry; PARADISO, A. Michael. Neurociências, desvendando o sistema nervoso. Porto Alegre: Artmed Editora, $2^{\mathrm{a}}$ edição.

BENSAFI, M; PORTER, J; POULIOT, S; MAINLAND, J; JOHNSON, B; ZELANO, C; YOUNG, N; BREMNER, E; AFRAMIAM, D; KHAN, R; SOBEL, N. Olfactomotor activity during imagery mimics that during perception. Nature Neuroscience, nov./2003. 
CAMPOS, Roland de Azeredo. Arteciência: afluência de signos co-moventes. São Paulo: Perspectiva, 2003.

CARDOSO, Silvia Helena, SABBATINI, Renato M.E. O Que Nos Faz Humanos? Editorial. Cérebro e mente. ㄲo 10, jan. - mar, 2000.

CARDOSO, Silvia Helena. Os neurônios e a Galáxia. Cérebro\&mente. ํำ 7, set.nov, 1998.

WHITE, R. W. 2002. The historic and legal context of foreign acquisitions of Paleolithic artifacts from the Périgord: 1900-1941. In L. Straus (ed.) The Rôle of American Archaeologists in the Study of the European Uper Paleolithic. Oxford: British Archaeological Reports, p. 71-83.

CAVANAGH, Patrick. The artist as neuroscientist. Nature, 434, 301-307 (2005).

CURI, Rui; PROCÓPIO, Joaquim. (org). Fisiologia Básica. Rio de Janeiro: Guanabara Koogan, 2007. (no prelo)

DAMÁSIO, Antonio. O erro de Descartes. São Paulo: Companhia das Letras, 1998. Os mistérios da Consciência. São Paulo: Companhia das Letras, 2001.

DEWEY, John. A arte como experiência. São Paulo: Abril Cultural, 1985.

DIAMOND, Marian et al. Rat Cortical Morphology following crowded-enriched living conditions. Experimental Neurology. 96 (2), 1987, p.241-247.

DOBBS, David (2006). Reflexo Revelador. Mente \& Cérebro ANO XIV no 161, p.4651.

DONDIS, Donis A. Sintaxe da linguagem visual. São Paulo: Martins Fontes Editora, 1991.

A primer of visual literacy. MIT Press Cambridge, Massachusetts, 1995. 
DUARTE, F. João Jr. Porque arte - educação? Campinas: Papirus, 2001.

ECO, Humberto. A definição da arte. Lisboa: Edições 70, 1981.

EFLAND, Arthur. A history of art education.Intelectual and social currents in teaching the visual arts. New York: Teacher College Press, 1990.

Arts and cognition. New York: Teacher College Press, 2002.

EINSTEIN, Albert. Escritos da maturidade: artigos sobre ciência, educação, relações sociais, racismo, ciências sociais e religião. Rio de Janeiro: Editora Nova Fronteira, 1994.

EISNER, Elliot. What can education learn from the arts about the practice education? International journal of education \& the arts. vol5 $n^{\circ}=4,2004$.

. The arts and the creation of mind. USA by Donnelley \& Sons, 2002.

ENGELMANN, Arno. A psicologia da gestalt e a ciência empírica contemporânea. Psicologia e Pesquisa, vol. 18 n.1, p.001-016. ( 2002 )

FERREIRA, Sueli (Org). O Ensino das Artes: Construindo Caminhos. Campinas: Papirus, 2001.

FISCHER, Ernst. A necessidade da arte. Rio de Janeiro: Editora Guanabara, 1987.

FREEMAN, Walter. A fisiologia da percepção. Mente e Cérebro. São Paulo, edição especial, set. 2005.

FUSARI, Maria F. R. e FERRAZ, Maria Heloísa C. Arte na educação escolar. São Paulo: Cortez Editora, 1993.

GALLESE, V.; FADIGA, L.; FOGASSI, L.; RIZZOLATTI, G. Action recognition in the premotor cortex. Brain, vol. 119, n² 2, 1996. p. 593-609. 
GALLESE, V.; GOLDMAN, A. Mirror neurons and the simulation theory of mindreading. Trends in Cognitive Sciences 2, 1998. p. 493-501.

GARDNER, Howard. A nova ciência da mente: uma história da revolução cognitiva. São Paulo: Editora da Universidade de São Paulo, 2003.

. Estruturas da mente. Porto Alegre: Artmed Editora, 1994.

GAZZANIGA, Michael S. Neurociência cognitiva a biologia da mente. Porto Alegre: Artmed, 2006.

GOMBRICH, Ernest H. A história da arte. Rio de Janeiro: Editora Guanabara, 1988. Arte e llusão: um estudo da psicologia da representação pictórica.Rio de Janeiro: Ed. Martins Fontes, 1986.

Breve história do mundo. São Paulo: Martins Fontes, 2001.

GOMES FILHO, João. Gestalt do objeto: sistema de leitura visual da forma. São Paulo: Escrituras Editora, 2004.

GOULD, Stephen Jay. A montanha de moluscos de Leonardo da Vinci. São Paulo: Companhia das Letras, 2003.

GUIMARÃES DOS SANTOS, C.L.N. Tópicos em neurociência cognitiva e reabilitação neuropsicológica. São Paulo: Unidade de Reabilitação Neuropsicológica, 1998.

HAGENDOOEN, Ivar. Some speculative hypotheses about the nature and perception of dance and choreography. Journal of Consciousness Studies. 11, ํo.3-4, 2004, p. $79-110$.

. The dancing brain. From Cerebrum: The Dana Forum on brain science. Vol.5, No.2, Spring 2003.

HAUSER, Arnold. História social da literatura e da arte. São Paulo: Editora Mestre Jou, 1978. 
HEMSY DE GAINZA, Violeta. Conversas com Guerda Alexander. São Paulo: Summus, 1997.

HERCULANO-HOUZEL, Suzana. O cérebro nosso de cada dia. Rio de Janeiro: Vieira e Lent, 2004.

IZQUIERDO, Iván. Memória. Porto Alegre: ArtMed Editora AS, 2002.

KANDEL, Eric R; SQUIRE, Larry R. Memória: da mente às moléculas. Porto Alegre: Artmed, 2003.

KANDEL, R. Eric; Schwartz, H. James; Jessell, M. Thomas. Fundamentos da Neurociência e do comportamento. Rio de Janeiro: Guanabara-Koogan, 2000.

KEMP, Martin. Leonardo da Vinci. Rio de Janeiro Jorge Zahar Ed. 2005.

KLEIN, Richard G. O despertar da cultura: a polêmica teoria sobre a origem da criatividade humana. Rio de Janeiro: Jorge Zahar Ed., 2005.

KOLB, Bryan; Whishaw, Q. lan. Neurociência do Comportamento. São Paulo: Editora Manole, 2002.

KOSSILYN, S. (1994). Image and brain: the resolution of the imagery debate. Cambridge, The MIT Press.

KRELMAN G.; KOCH C.; FRIED I. (2000). Imagery neurons in the human brain. Nature 408, 2000. p. 357-360.

LANGER, Susanne K. Los problemas del arte. Buenos Aires: Ediciones Infinito, 1966.

Sentimento e forma. São Paulo: Editora perspectiva, 1980.

LARAIA, Roque de Barros. Cultura: um conceito antropológico. Rio de Janeiro: Jorge Zahar, 1988. 
LENT, Roberto. Cem bilhões de neurônios; conceitos fundamentais de neurociência. Rio de Janeiro: Ateneu, 2004.

LICHTENSTEIN, Jacqueline (org.) A pintura - Vol. 1: O mito da Pintura. São Paulo: Ed. 34,2004.

LIVINGSTONE, Margaret. Vision and art: the biology of seeing. New York: Abrams, 2002.

LOWENFELD, Viktor; BRITTAIN, W.L. Desenvolvimento da atividade criadora. São Paulo: Editora Mestre Jou, 1977.

LURIA, A. R. A construção da mente. São Paulo: Ícone, 1992.

Desenvolvimento cognitivo: seus fundamentos culturais e sociais. São Paulo: Ícone, 1990.

MACHADO, Regina. Acordais, fundamentos teóricos - poéticos da arte de contar histórias. São Paulo: DCL, 2004.

Arte educação e o conto de tradição oral: elementos para uma pedagogia do imaginário. 1989. 414 págs. (Doutorado). Escola de Comunicações e Artes da Universidade de São Paulo.

MASSIRONI, Manfredo. Ver pelo desenho; aspectos técnicos, cognitivos, comunicativos. Lisboa : Edições 70, 1982.

MITHEN, Steven J. A pré-história da mente: uma busca das origens da arte, da religião e da ciência. São Paulo: Editora UNESP, 2002.

MORAIS, Frederico. Arte é o que eu e você chamamos arte: 801 definições sobre arte e o sistema da arte. Rio de Janeiro: Record, 2004.

MORAIS, Regis de. Estudos de filosofia da cultura. São Paulo: Edições Loyola, 1992. 
OCDE. Compreendendo o cérebro: rumo a uma nova ciência do aprendizado. São Paulo: Editora Senac, 2003.

OECD (org.). Brain Mechanisms and early learning: Learning Sciences and Brain Research: Potential implications for education polices and practices. New York SA, June 2000.

OECD (org.). Brain Mechanisms and early learning: Learning Sciences and Brain Research: Potential implications for education polices and practices. Granada, Spain, fev.2001.

OECD (org.). Brain Mechanisms and early learning: Learning Sciences and Brain Research: Potential implications for education polices and practices. Tokio, Japan, 2001.

OSBORNE, Harold. Estética e teoria da arte: uma introdução histórica. São Paulo: Editora Cultrix, 1974.

OSTROWER, Fayga. A grandeza humana. Rio de Janeiro: Editora Campus, 2003. A sensibilidade do intelecto. Rio de Janeiro: Campus, 1998. Acasos e criação artística. Rio de Janeiro: Editora Campus, 1999. Criatividade e processos de criação. Petrópolis: Vozes, 1987. Universos da arte: edição comemorativa Fayga Ostrower. 24a ed. Rio de Janeiro: Elsevier, 2004.

PAREYSON, Luigi. Estética: teoria da formatividade. Petróplois: Editora Vozes, 1993.

1989. Os problemas da estética. São Paulo: Martins Fontes Editora, PINKER, Steven. Como a mente funciona. São Paulo: Companhia das letras, 2005. 
RAMÓN Y CAJAL, Santiago. El mundo visto a los ochenta años. Buenos: Editora Espasa - Calpe Argentina, 1941.

Mi infancia y juventud. Buenos Aires: Editora Espasa - Calpe Argentina, 1939.

RELEITURA. Resumo biográfico e bibliográfico de João Guimarães Rosa. Disponível em: <http://www.releituras.com/guimarosa_bio.asp>. Acesso em out. de 2006.

ROOT-BERNSTEIN, Robert; ROOT-BERNSTEIN, Michèle. Centelhas de gênios: como pensam as pessoas mais criativas do mundo. São Paulo: Nobel, 2001.

ROSENZWEIG, M.R. Aspects of the search for neural mechanisms of memory. Annual Review of Psychology, 47, 1-32. 1996.

SACKS, Oliver. O homem que confundiu sua mulher com um chapéu. São Paulo: Companhia das Letras, 1997.

SANTOS, José Luiz dos. O que é Cultura. São Paulo: Editora Brasiliense, 1985.

STRICKLAND, Carol; BROSWELL, John. Arte Comentada: da pré-história ao pósmoderno. Rio de Janeiro: Ediouro, 2004.

TATTERSAL, Ian (2006). Como nos tornamos humanos. Scientific American Brasil, Edição Especial, p.68-75.

WHITE, R. W. 2002. Observations technologiques sur les objets de parure in B. Schmider (ed.) L'Aurignacien de la grotte de Renne: Les fouilles d'André LeroiGourhan à Arcy-sur-Cure (Yonne). XXXIV e Suplément à Gallia Préhistoire, 257266.

ZAMBONI, Silvio. A Pesquisa em Arte: um paralelo entre arte e ciência. Campinas: Autores Associados, 2001.

ZATORRE, Robert. Music, the food of neuroscience? Nature Vol.434,17 March 2005. 
ZÖLLNER, Frank. Leonardo da Vinci: desenhos e esboços. TASCHEN GmbH, Edição Especial: Paisagem distribuidora de Livros, 2005.

Leonardo da Vinci: pinturas completas. TASCHEN GmbH, Edição Especial: Paisagem distribuidora de Livros, 2005. 


\section{GLossÁRIO}

Abordagens gestálticas à percepção da forma - modo de estudo da percepção da forma, baseado na noção de que a forma btal difere da soma de suas partes individuais; uma gestalt (forma) é a totalidade distintiva de um todo integrado, em oposição à mera soma das várias partes.

Ação artística - É a ação realizada a partir de uma intenção e nela estão contidos tanto o fazer (executar), o conhecer (a cognição) e o exprimir de tal forma que qualifica de modo especial e característico essas três funções da arte. A ação artística revela frequentemente, um sentido das coisas e faz com que um particular fale de modo novo e inesperado, mostrando uma nova maneira de olhar e ver a realidade.

Aferente - adjetivo que qualifica um elemento que chega a um ponto de referência qualquer do sistema nervoso.

Agnosia - um déficit grave na capacidade para perceber a informação sensorial, geralmente relacionado à modalidade sensorial visual; estranhamente, os agnósicos têm sensações normais, mas carecem da capacidade para interpretar e reconhecer o que sentem, usualmente em conseqüência a lesões cerebrais.

Amigdala - pequena estrutura em forma de amêndoa, situada dentro da região antero-inferior do lobo temporal. Interconecta-se com o hipocampo, os núcleos septais, a área pré-frontal e o núcleo dorso-medial do tálamo. Essas conexões garantem seu importante desempenho na mediação e controle das atividades emocionais de ordem maior, como amizade, amor e afeição, nas exteriorizações do humor e, principalmente, nos estados de medo e ira e na agressividade. A amigdala é fundamental para a auto-preservação, por ser o centro identificador do perigo, gerando medo e ansiedade e colocando o animal em situação de alerta, aprontando- 
se para se evadir ou lutar. A destruição experimental das amigdalas (são duas, uma para cada um dos hemisférios cerebrais) faz com que o animal se torne dócil, sexualmente indiscriminativo, afetivamente descaracterizado e indiferente às situações de risco. O estímulo elétrico dessas estruturas provoca crises de violenta agressividade. Em humanos, a lesão da amigdala faz, entre outras coisas, com que o indivíduo perca o sentido afetivo da percepção de uma informação vinda de fora, como a visão de uma pessoa conhecida. Ele sabe quem está vendo, mas não sabe se gosta ou desgosta da pessoa em questão.

Amnésia - perda grave de memória, geralmente afetando mais a memória declarativa do que a memória procedural.

Aprendizado - alterações relativamente permanentes no comportamento de um organismo que é resultado de uma experiência.

Assimilação - processo equilibrador pelo qual uma pessoa incorpora a nova informação aos esquemas cognitivos existentes.

Atenção - relação cognitiva entre a quantidade limitada de informação que realmente controlamos mentalmente e a enorme quantidade de informação disponível através de nossos sentidos, memórias armazenadas e outros processos cognitivos.

Atenção dividida - processo pelo qual uma pessoa distribui os recursos atentivos disponíveis para coordenar a execução de mais de uma tarefa ao mesmo tempo.

Atenção seletiva - processo pelo qual uma pessoa tenta seguir a pista de um estímulo ou de um tipo de estímulo e não prestar atenção a outro.

Bainha de mielina - fita espiralada, disposta em torno de alguns axônios periféricos e centrais, que tem a função isolante e contribui para aumentar a velocidade de condução do impulso nervoso.

Bulbo olfativo - local no cérebro que funciona como um centro organizador de 
sinais olfativos. São duas zonas do cérebro, situadas debaixo da parte anterior de cada um dos hemisférios cerebrais. É a sede central de elaboração das impressões olfativas transmitidas pelo nervo correspondente.

Células estelares - são neurônios arredondados; seus axônios não deixam o córtex. Essas células servem para estabelecer as conexões com as colunas corticais.

Células piramidais - projetam seus axônios para outras áreas do cérebro e medula espinhal, são neurônios excitatórios e a maioria dentre os neurônios de projeção do córtex cerebral.

Cerebelo - vem do latim e significa "pequeno cérebro". O cerebelo fica localizado ao lado do tronco encefálico. É parecido com o córtex cerebral em alguns aspectos: o cerebelo é dividido em hemisférios e tem um córtex que recobre estes hemisférios. É a parte do encéfalo responsável pela manutenção do equilíbrio e postura corporal, controlo do tónus muscular e dos movimentos voluntários, bem como pela aprendizagem motora.

Cérebro - é o principal constituinte do encéfalo; além de ser, ainda, o principal órgão do sistema nervoso central e o centro de controle de muitas atividades voluntárias e involuntárias do nosso corpo. Ele também é responsável por ações complexas, como pensamento, memória, emoção e linguagem.

Circuitos nervosos - são conjuntos de neurônios que se comunicam entre si através de junções denominadas de sinapses.

Codificação - processo pelo qual um input sensorial físico é transformado numa representação que pode ser armazenada na memória.

Cognição - ato ou processo de conhecer. Inclui a atenção, a percepção, a memória, o raciocínio, o juízo, a imaginação, o pensamento e o discurso. 
Comportamento - Segundo a Análise do Comportamento, comportamento é toda e qualquer interação de um organismo vivo com o seu ambiente. Isto é, tudo o que fazemos (abrir uma porta, pensar, perceber, ler etc.) numa relação com o ambiente, pode ser interpretado como comportamento (e consequentemente, estudado pela Análise do Comportamento). Desta forma, comportamento não é exatamente um sinônimo de resposta, mas a relação entre a resposta e o ambiente. Ação, atividade e atitude são alguns dos termos que, dependendo do contexto, podem ser considerados como equivalentes a comportamento ou resposta.

Conhecimento declarativo - informações reais que as pessoas conhecem sobre objetos, idéias e eventos, no ambiente.

Conservação - a capacidade para considerar mentalmente a estabilidade de uma dada quantidade, apesar das mudanças observadas na aparência do objeto ou da substância.

Corpo caloso - localiza-se no fundo da fissura inter-hemisférica, ou fissura sagital, é a estrutura responsável pela conexão entre os dois hemisférios cerebrais. Essa estrutura, composta por fibras nervosas de cor branca (freixes de axónios envolvidos em mielina), é responsável pela troca de informações entre as diversas áreas do córtex cerebral.

Córtex cerebral - a palavra córtex vem do latim e significa "casca". Isto porque o córtex é a camada mais externa do cérebro. A espessura do córtex cerebral varia de dois a seis milímetros. O lado esquerdo e direito do córtex cerebral são ligados por um feixe grosso de fibras nervosas chamado de corpo caloso. O córtex cerebral está dividido em mais de 40 áreas funcionalmente distintas, sendo a maioria pertencente ao chamado neocórtex.

Córtex motor - é responsável pelo controle e coordenação da motricidade voluntária. Traumas nesta área causam fraqueza muscular ou mesmo paralisia. 0 
córtex motor do hemisfério esquerdo controla o lado direito do corpo, e o córtex motor do hemisfério direito controla o lado esquerdo do corpo. Cada córtex motor contém um mapa da superfície do corpo: perto da orelha, está a zona que controla os músculos da garganta e da língua, segue-se depois a zona dos dedos, mão e braço; a zona do tronco fica ao alto e as pernas e pés vêm depois, na linha média do hemisfério.

Córtex olfativo - localizado ventral e lateralmente ao hipocampo; apresenta duas ou três camadas celulares.

Córtex pré-motor - é responsável pela aprendizagem motora e pelos movimentos de precisão. É na parte em frente da área do córtex motor, correspondente à boca, que reside a Área de Broca, relativa à linguagem. A área pré-motora fica mais ativa do que o resto do cérebro quando se imagina um movimento, sem o executar. Se se executa, a área motora fica também ativa. A área pré-motora parece ser a área que em grande medida controla o sequenciamento de acções em ambos os lados do corpo. Traumas nesta área não causam nem paralisia nem problemas na intenção para agir ou planejar, mas a velocidade e suavidade dos movimentos automáticos (ex. fala e gestos) fica perturbada. A prática de piano, tênis ou golfe envolve a zona pré-motora - sobretudo a esquerda, especializada largamente em atividades sequênciais do tipo série.

Dendritos - parte do neurônio, estas estruturas se ramificam como galhos de uma árvore e servem como o principal aparato para receber sinais de outras células nervosas. Eles funcionam como "antenas" do neurônio e são cobertos por milhares de sinapses. A membrana dendrítica sob a sinapse (a membrana pós-sinaptica) tem muitas moléculas de proteínas especializadas, os receptores, que detectam os neurotransmissores na fenda sinaptica. Uma célula nervosa pode ter muitos dendritos que se ramificam muitas vezes, sua superfície é irregular e coberta em espinhas dendríticas, que é o local onde as conexões sinapticas são feitas.

Desenvolvimento cognitivo - trata-se de mudanças qualitativas no pensamento, que ocorrem ao longo da duração média de vida, em associação à progressiva maturidade fisiológica (maturação) e experiência (aprendizagem). 
Eferente - adjetivo que qualifica um elemento que sai de um ponto de referência do sistema nervoso.

Emoção - é uma resposta neuronal e fisiológfica ao estímulo potencialmente emocional.

Engrama - é o somatório total das alterações no encéfalo, que codificaram inicialmente uma experiência e que, então, constituem o registro daquela experiência.

Evocação - um processo de memória freqüentemente empregado em tarefas de memória, no qual se solicita que a pessoa produza (não apenas o reconheça como correto) um fato, uma palavra ou outro item de memória.

Figura-fundo - um princípio gestáltico da percepção da forma: a tendência a perceber que um objeto em um campo perceptivo ou um aspecto deste parece proeminente (denominado de figura), enquanto outros aspectos ou objetos recuam para o plano de fundo (denominado de fundo).

Gestalt - embora não haja equivalente preciso em português para a palavra alemã gestalt, o sentido mais geral que se pode dar ao termo seria uma espécie de disposição ou configuração de uma organização específica das partes que constituiria um todo particular.

Habituação - tendência a acostumar-se a um estímulo e gradualmente notá-lo cada vez menos.

Hipocampo - é uma área do sistema límbico que é muito importante na memória, aprendizado e estados emocionais. É uma região do córtex que está dobrada sobre si e possui apenas três camadas celulares; localiza-se medialmente ao ventrículo lateral. Tem particular envolvimento com a formação da chamada memória de longa duração (aquela que persiste, às vezes, para sempre). Quando ambos os 
hipocampos (direito e esquerdo) são destruídos, nada mais é gravado na memória. O indivíduo esquece, rapidamente, a mensagem recém recebida. Um hipocampo intacto possibilita ao animal comparar as condições de uma ameaça atual com experiências passadas similares, permitindo-lhe, assim, escolher qual a melhor opção a ser tomada para garantir sua preservação.

Hipotálamo - também constituído por substância cinzenta, é o principal centro integrador das atividades dos órgãos viscerais, sendo um dos principais responsáveis pela homeostase corporal. Ele faz ligação entre o sistema nervoso e o sistema endócrino, atuando na ativação de diversas glândulas endócrinas. É o hipotálamo que controla a temperatura corporal, regula o apetite e o balanço de água no corpo, o sono e está envolvido na emoção e no comportamento sexual. Tem amplas conexões com as demais áreas do prosencéfalo e com o mesencéfalo. É aceito que o hipotálamo desempenha, ainda, um papel nas emoções. Especificamente, as partes laterais parecem envolvidas com o prazer e a raiva, enquanto que a porção mediana parece mais ligada à aversão, ao desprazer e à tendência ao riso (gargalhada) incontrolável. De um modo geral, contudo, a participação do hipotálamo é menor na gênese (criação) do que na expressão (manifestações sintomáticas) dos estados emocionais.

Imaginação - representação mental de objetos, de eventos, de ambientes e de outras coisas que não são imediatamente perceptíveis aos receptores sensoriais.

Impulso nervoso - é a transmissão de um sinal codificado de um dado estímulo ao longo da membrana do neurônio, a partir do ponto em que ele foi estimulado. É o evento como a informação é processada. A direção normal do impulso no organismo é do corpo celular para o axônio.

Inteligência - capacidade para aprender a partir da experiência e adaptar-se ao ambiente circundante.

Interdisciplinariedade - é a união dos componentes distintos de duas ou mais disciplinas, conduzindo a novos conhecimentos que não seriam possíveis se não fosse esta integração. A interdisciplinariedade ocorre quando as disciplinas se integram e colaboram entre si. 
Lobos - são as principais divisões físicas do córtex cerebral.

Luminância - quantidade de energia que emerge de uma fonte.

Mapas cognitivos - representações mentais do ambiente físico, particularmente quanto às relações espaciais entre os objetos no ambiente.

Memória - os meios pelos quais as pessoas recorrem ao conhecimento passado, a fim de utilizá-lo no presente; os mecanismos dinâmicos associados à retenção e à recuperação da informação.

Memória de trabalho - uma fração da memória que pode ser considerada como uma parte especializada da memória de longo prazo; mantém apenas a fração ativada mais recentemente deste tipo de memória e transfere esses elementos ativados para dentro e para fora da memória de curto prazo.

Memória episódica - codificação, armazenamento e recuperação de eventos ou episódios que a pessoa que recorda vivenciou, em um determinado tempo e lugar.

Memória explícita - uma forma de recuperação da memória na qual uma pessoa age conscientemente para evocar ou reconhecer determinada informação.

Memória implícita - uma forma de recuperação da memória na qual uma pessoa usa a informação lembrada, sem estar conscientemente inteirada da lembrança dessa informação.

Memória semântica - codificação, armazenamento e recuperação de fatos (por exemplo, conhecimento declarativo a respeito do mundo); em alguns modelos, os fatos não descrevem as experiências singulares da pessoa que evoca os fatos (cf. com memória episódica).

Mente - é a resultante gerada a partir do funcionamento encefálico. Pode ser tratada através de remédios antidepressivos, antipsicóticos ou ansiolíticos, e de 
diferentes tipos de psicoterapia. As funções mentais podem referir-se a localizações anatômicas mais ou menos específicas: fazer, lembrar e extinguir memórias é função importante do hipocampo. A mente é função do corpo e dele depende para existir, sofrer e se manifestar. Nas funções mentais participam: a percepção, o nível de alerta, a seleção do que queremos perceber, recordar ou aprender, a decisão sobre o que queremos fazer ou deixar de fazer, a vontade, a compreensão, os sentimentos, as emoções, os estados de ânimo e tudo aquilo que é englobado sob os conceitos de inteligência e consciência.

Multidisciplinariedade - ocorre quando as disciplinas trabalham lado a lado em distintos aspectos de um único problema.

Neocórtex - córtex mais complexo; separa-se do córtex olfativo mediante um sulco chamado fissura rinal; apresenta muitas camadas celulares e várias áreas sensoriais e motoras. As áreas motoras estão intimamente envolvidas com o controle do movimento voluntário.

Nervo - conjunto de fibras nervosas, aglomeradas em paralelo, geralmente situado no sistema nervoso periférico, formando longos cordões revestidos de tecido conjuntivo.

Neurônio - célula especializada do sistema nervoso capaz de conduzir sinais elétricos.

Neuroreceptores - receptores encontrados na célula nervosa. Têm como missão, receber mensagens químicas específicas e traduzi-las nas correspondentes respostas neuronais pós-sinápticas. Acredita-se que a superfície externa do neuroreceptor serve para reconhecer e unir-se ao neurotransmissor, enquanto a superfície interna efetua as alterações intracelulares esperadas.

Neurotransmissor - substância sintetizada pelo neurônio, armazenada em vesículas e liberada para o espaço extra-celular com a função de transmitir informação entre um neurônio e outra célula situada na proximidade. 
NIR - Espectroscopia no infravermelho próximo. Método não-invasivo de captação de imagem, que permite medir a concentração de hemoglobina desoxigenada no cérebro por absorção do infravermelho próximo (a luz do infravermelho próximo, de comprimento de o0nda entre $700 \mathrm{~nm}$ e $900 \mathrm{~nm}$, pode penetrar parcialmente no tecido humano).

Núcleo - aglomeração de neurônios do sistema nervoso central, identificável ao microscópio por suas características morfológicas, e geralmente tem uma única função.

Percepção - o conjunto de processos psicológicos pelos quais as pessoas reconhecem, organizam e fornecem significação (no cérebro) às sensações recebidas dos estímulos ambientais (nos órgãos dos sentidos).

Percepção subliminar - forma de processamento pré-consciente, na qual as pessoas são capazes de detectar a informação sem estarem conscientes de que estão fazendo isso.

Percepto — representação mental de um estímulo que é percebido.

PET - Tomografia por emissão de pósitrons. Técnica em que, com a utilização de um radionuclídeo, produz-se a emissão de pósitrons e cria-se uma imagem da atividade cerebral. A tomografia por emissão de pósitrons produz imagens tridimensionais e coloridas da atividade química do encéfalo.

Plasticidade - uma característica da cognição humana, pela qual parecemos ser ilimitadamente capazes de modificar nossos processos e produtos cognitivos, melhorando nossa eficácia nas tarefas com as quais nos deparamos.

Plasticidade neural - é a propriedade do sistema nervoso que permite o desenvolvimento de alterações estruturais em resposta à experiência, e como adaptação a condições mutantes e a estímulos repetidos. 
Pós-imagem - imagem negativa de um objeto muito claro fixado durante um tempo prolongado, e observado em seguida com os olhos fechados ou em algum ambiente escuro.

Potencial de ação - é um fenômeno de natureza eletro-química e ocorre devido a modificações na permeabilidade da membrana do neurônio.

Priming - processo pelo qual estímulos iniciais específicos ativam vias mentais que aumentam a capacidade para processar os estímulos subseqüentes, relacionados aos estímulos priming sob certo aspecto.

Raciocínio - refere-se a como nós chegamos a conclusões. Com base em informações tiramos inferências ou conclusões.

Representação do conhecimento - forma mental pela qual as pessoas conhecem as coisas, as idéias, os eventos, etc. que existem fora de suas mentes.

RMf - Ressonância magnética funcional. Utiliza-se um scanner para monitorar indiretamente a atividade neural por meio de mudanças químicas do sangue (como o nível do oxigênio) e investigar aumentos de atividade dentro das áreas cerebrais associadas a vários estímulos e tarefas mentais.

Semântica - o estudo das significações, sob forma de linguagem.

Sentimento - é quando a emoção atinge a consciência e é codificada.

Simbólica - significa uma forma de representação que foi escolhida arbitrariamente para representar algo e que não se assemelha perceptivamente a tudo o que está sendo representado.

Sinal - estímulo a ser detectado; segundo a teoria da detecção de sinal, há quatro pares de estímulo-resposta possíveis: um acerto, um erro, um alarme falso ou uma rejeição correta. 
Sinapse - região de proximidade entre dois neurônios, ou entre um neurônio e uma célula muscular, por onde passa a informação neural. São nestas junções que os neurônios são excitados, inibidos ou modulados. Existem dois tipos de sinapses, a elétrica e a química.

Sinapses Elétricas - ocorrem onde o terminal pré-sináptico está em continuidade com o pós-sináptico. ĺons e pequenas moléculas passam por eles, conectando então canais de uma célula à próxima, de forma que alterações elétricas em uma célula são transmitidas quase instantaneamente à próxima. Os íons podem gerar fluxos em ambos as direções destas junções, embora eles tendam a ser unidirecionais.

Sinapses nervosas - são os pontos onde as extremidades de neurônios vizinhos se encontram e o estímulo passa de um neurônio para o seguinte por meio de mediadores químicos, os neurotransmissores. As sinapses ocorrem quando as terminações nervosas (axônios) que estão em "contato" com os dendritos, o contato fisíco não existe realmente, pois ambas estruturas estão próximas, mas há um espaço entre elas (fenda sináptica). Dos axônios são liberadas substâncias (neurotransmissores), que atravessam a fenda e estimulam receptores nos dentritos e assim transmitem o impulso nervoso de um neurônio para o outro

Sinapses Químicas - o modo de transmissão não é elétrico, e sim carreado por neurotransmissores, substâncias neuroativas liberadas no lado pré-sináptico da junção. Existem dois tipos de junções químicas. O tipo I é uma sinapse excitatória, geralmente encontrada em dendritos; o tipo II é uma sinápse inibitória, geralmente encontrada em corpos celulares. Substâncias diferentes são liberadas nestes dois tipos de sinapses.

Sistema Límbico - é um grupo de estruturas que inclui hipotálamo, tálamo, amígdala, hipocampo, os corpos mamilares e o giro do cíngulo. Todas estas áreas são muito importantes para a emoção e reações emocionais. O hipocampo também é importante para a memória e o aprendizado.

Sistema motor - conjunto de regiões interligadas ao sistema nervoso, que se encarregam de diferentes aspectos da motricidade. 
Tálamo - todas as mensagens sensoriais, com exceção das provenientes dos receptores do olfato, passam por ele antes de atingir o córtex cerebral. Esta é uma região de substância cinzenta localizada entre o tronco encefálico e o cérebro. 0 tálamo atua como estação retransmissora de impulsos nervosos para o córtex cerebral. Ele é responsável pela condução dos impulsos às regiões apropriadas do cérebro, onde eles devem ser processados. O tálamo também está relacionado com alterações no comportamento emocional, que decorrem, não só da própria atividade, mas também de conexões com outras estruturas do sistema límbico (que regula as emoções).

Timbre - percepção da combinação característica de freqüências e seus harmônicos, emitidos por uma determinada fonte sonora.

Tom — percepção de uma freqüência pura emitida por uma fonte sonora.

Transdução - é a conversão de uma forma de sinal físico ou químico em outra. Em biologia celular a transdução de sinais refere-se a um processo seqüencial iniciado pela ligação de um sinal extracelular a um receptor e culminando em uma ou mais respostas celulares específicas.

Tronco - conjunto de fibras nervosas paralelas, semelhante ao nervo, mas mais calibroso que este. 


\section{ANEXOS}

\section{HeMisfÉRIo CeREBRAL DiREITO E ESQUERDO}

Quando o psicólogo Roger Sperry (1913-1994) ganhou o prêmio Nobel de medicina e fisiologia, em 1981, por seus estudos sobre a especialização hemisférica, houve um grande interresse da mídia pelo tema.

A descoberta da especialização hemisférica, ao ser levada ao público pelos meios de comunicação, incorporou uma visão exageradamente simplista da questão: um dos hemisférios seria "verbal", o outro "espacial"; um usaria a Razão, o outro a Emoção, e assim por diante. Essas dicotomias exageradas levaram, inclusive, a recomendações não-científicas do tipo: "pense com o hemisfério direito", "aja com o hemisfério esquerdo". Essas recomendações são totalmente infundadas.

Betty Davis, professora de desenho americana, desenvolveu o método de desenho Desenhando com o lado direito do cérebro, apoiada nas pesquisas de Roger Sperry. O método de Betty Davis é interessante e ajudou muitos estudantes a desenvolverem suas potencialidades. Porém, não tem comprovação científica experimental que seja aceita na comunidade científica. $O$ fato das pessoas aprenderem a desenhar a partir das estratégias criadas por Betty Davis, não significa que suas justificativas e considerações a respeito do funcionamento dos hemisférios cerebrais estejam corretas.

Após 25 anos de equívocos gerados pela mídia e por leigos irresponsáveis, torna-se difícil desfazer esse engano com poucas palavras. Por isso, recorro ao neuroanatomista Roberto Lent, que, em seu livro Cem Bilhões de 
Neurônios, relata com clareza esse tema: a especialização hemisférica. Creio que essa leitura contribuirá, de forma adequada, para suprir essa lacuna de informação.

\section{Trecho retirado de LENT, 2004, p. 642- 646}

"Quando Paul Broca apresentou à Societé Anatomique os seus pacientes afásicos, contribuiu ao mesmo tempo para fortalecer o conceito de localização de funções no sistema nervoso e lançar a idéia de dominância hemisférica, precursora da concepção moderna de especialização funcional dos hemisférios cerebrais. Durante muitas décadas os neurologistas pensaram que o hemisfério esquerdo, sede do 'centro que fala' (como pensava Broca), era dominante sobre o hemisfério direito. Este, portanto, exerceria apenas funções coadjuvantes e secundárias.

Um século depois as evidências mostraram que não era bem assim, e o conceito de dominância hemisférica se tornou ultrapassado. Percebeu-se que não há um hemisfério dominante e outro dominado, mas sim dois hemisférios especializados. Um dos hemisférios se encarrega de um grupo de funções, o segundo encarrega-se de outro. Ambos, no entanto, trabalham em conjunto, utilizando-se dos milhões de fibras nervosas que constituem as comissuras cerebrais e se encarregam se pô-los em constante interação. O novo conceito - especialização hemisférica -, de certo modo, confunde-se com dois outros relacionados: o de lateralidade e o de assimetria. Lateralidade hemisférica é um conceito essencialmente funcional: significa que, enquanto algumas funções são representadas igualmente em ambos os hemisférios (como a visão, por exemplo), outras são representadas apenas de um lado (como a fala). Assimetria é um 
conceito mais geral, que engloba o de lateralidade e apresenta-se sob várias modalidades: assimetrias morfológicas, funcionais e comportamentais. Significa que os hemisférios não são simétricos, quando vemos sob esses diferentes ângulos: sua forma à direita é diferente da esquerda, a representação funcional idem, e assim também os comportamentos que os hemisférios controlam.

A descoberta da especialização hemisférica, ao ser levada ao público pelos meios de comunicação, incorporou uma visão exageradamente simplista da questão: um dos hemisférios seria "verbal", o outro "espacial"; um usaria a Razão, o outro a Emoção, e assim por diante. Essas dicotomias exageradas levaram, inclusive, a recomendações não-científicas do tipo: "pense com o hemisfério direito", "aja com o hemisfério esquerdo", e outras tantas...

\section{Pessoas com o Cérebro Dividido}

Depois de Broca, uma grande explosão de conhecimento sobre a especialização dos hemisférios surgiu a partir da década de 60, com as pesquisas que levaram o psicólogo Roger Sperry (1913-1994) a merecer o prêmio Nobel de medicina e fisiologia em 1981, por seus estudos sobre a especialização hemisférica e as comissuras cerebrais.

As comissuras cerebrais são três (fíguras 19.17): o corpo caloso, a comissura anterior e a comissura do hipocampo. O corpo caloso é a maior delas, possuindo cerca de 200 milhões de fibras que interconectam a maior parte do cortéx cerebral de ambos os hemisférios. A comissura anterior põe em contato as regiões inferiores e ventrais do lobo temporal, e a comissura do hipocampo conecta as regiões temporais mediais.

Embora se pudesse imaginar, até os anos 60 ninguém sabia ao certo o 
uso das comissuras, porque os experimentos realizados em animais até essa ocasião não eram muito esclarecedores, a não ser para revelar o óbvio: que as comissuras transmitiam informações entre os hemisférios cerebrais. Acresce que alguns indivíduos haviam sido submetidos à transsecção cirúrgica do corpo caloso por indicação terapêutica, sem que os neurologistas pudessem detectar qualquer alteração funcional ou sintoma proveniente dessa cirurgia tão radical. Era espantoso que um feixe contendo 200 milhões de fibras não fizesse falta!

As cirurgias de transsecção das comissuras cerebrais são recomendadas para pacientes com epilepsias muito graves. Esses pacientes podem ter dezenas de crises convulsivas por dia, o que, além de lhes inviabilizar a vida social, vai aos poucos causando a morte de vários contingentes crescentes de células nervosas. Verificou-se empiricamente que a interrupção do corpo caloso impede que o foco epiléptico - local de origem da crise - se espraie para o hemisfério oposto, e com isso se generalize. O número de crises então diminuiu, e a epilepsia pode ser controlada com medicamentos.

Sperry imaginou um experimento engenhoso utilizando, como sujeitos, dois indivíduos com o cérebro dividido, isto é, os pacientes cujas comissuras haviam sido interrompidas cirurgicamente. Depois de recuperado da operação, o paciente se senta em frente a uma tela translúcida (figura 19.18A) sobre a qual o pesquisador pode projetar diapositivos com imagens variadas. Por trás da tela, o paciente tem acesso manual a diferentes objetos que correspondem de algum modo às imagens projetadas. O experimento começa com o indivíduo fixando um ponto bem no centro da tela. Em seguida, o pesquisador projeta à esquerda do ponto de fixação (hemicampo visual esquerdo) uma letra ( $R$, por exemplo), e à direita outra ( $L$, por exemplo). A imagem da letra permanece na tela por penas $150 \mathrm{~ms}$, um tempo tão 
breve que impede que ele involuntariamente retire os olhos do ponto central de fixação. Com isso, a letra $R$ projetada no hemicampo visual esquerdo será exclusivamente representada no hemisfério direito, e a letra $L$ projetada no hemicampo direito será representada exclusivamente no hemisfério esquerdo. 0 pesquisador pode, então, perguntar ao indivíduo o que ele viu na tela (figura 19.18B). Ele dirá: L Mas se for solicitado para encontrar com a mão esquerda o objeto correspondente (letras de plástico atrás da tela), pegará a letra $R$ e não a $L$. Parece impossível, mas a explicação é simples: só o hemisfério esquerdo viu L; portanto o paciente só consegue falar o que o hemisfério da linguagem viu. Mas como o hemisfério direito viu $R$ e é ele que comanda a mão esquerda, a resposta nesse caso será diferente.

Esse déficit que o paciente comissurotomizado apresenta faz parte da síndrome de desconexão inter-hemisférica, um termo que expressa a incapacidade dos hemisférios de trocar informação. Sperry e seis colaboradores tiraram partido dessa síndrome, desenvolvendo um modo eficiente de lateralizar estímulos, isto é, de fazê-los incidir exclusivamente sobre um dos hemisférios. Tornou-se possível então apresentar a cada hemisfério separadamente cálculos matemáticos, figuras tridimensionais para montar mentalmente, imagens com conteúdo emocional e toda sorte de estímulos. Além do sistema visual, estímulos auditivos lateralizados podem ser apresentados simultaneamente através de fones de ouvido e estímulos somestésicos apresentados às mãos. A resposta do hemisfério esquerdo é aferida através da fala, e a do hemisfério direito através de ações da mão esquerda. Foi possível revelar que as comissuras são responsáveis por unificar os campos sensoriais, especialmente os dois hemicampos visuais, e é delas também a responsabilidade de sincronizar o processamento funcional de ambos os 
hemisférios. Ao falar, por exemplo, simultaneamente veiculamos informações cognitivas e afetivas, e isso resulta da atividade coordenada de ambos os hemisférios através das comissuras. Finalmente, o trabalho de Sperry provocou uma intensa discussão de interesse filosófico. Se temos dois hemisférios e eles são diferentes, será que isso significa que temos dois cérebros? E se temos dois cérebros, isso significa que temos duas mentes?

O estudo da especialização hemisférica não se restringiu aos indivíduos com o cérebro dividido. Afinal, não se pode esquecer que eles são doentes epilépticos graves, e talvez as funções que eles revelam nos experimentos de Sperry não sejam inteiramente normais.

Outros estudos foram feitos com indivíduos normais, sempre utilizando estímulos lateralizados. A forma de revelar a especialização hemisférica, entretanto, tem de ser diferente porque os indivíduos normais dispõem de comissuras que distribuem a informação para o hemisfério oposto. Para contornar essa dificuldade, utiliza-se a cronometria mental. Quando um hemisfério processa uma informação que recebe diretamente, e ele mesmo comanda a resposta (neste caso geralmente manual), o tempo de reação do indivíduo tende a ser mais curto do que quando ele a recebe no hemisfério oposto. A diferença é atribuída ao tempo de passagem pelas comissuras. Nos últimos anos, as técnicas de imagem morfológicas e funcionais, bem como os métodos de registro eletro e magnetofisiológico, foram empregados em indivíduos normais para identificar a existência de assimetrias hemisféricas, associadas aos estudos morfológicos tradicionais realizados em cérebros de indivíduos falecidos. Os resultados, de um modo geral, confirmaram e ampliaram os resultados originalmente obtidos por Sperry e seus colaboradores. 


\section{Os Hemisférios não são Iguais}

Os experimentos utilizando pessoas com o cérebro dividido, complementados com os que empregam indivíduos normais, revelaram que as especialidades dos hemisférios podem ser bem diferentes (figura 19.19). Revelaram, também, que raramente a especialização hemisférica significa exclusividade funcional. O hemisfério esquerdo controla a fala em mais de $95 \%$ dos seres humanos, mas isso não quer dizer que o direito não participe: ao contrário, é a prosódia do hemisfério direito que confere à fala nuances afetivas essenciais para a comunicação interpessoal. O hemisfério esquerdo é melhor na realização mental de cálculos matemáticos, no comando da escrita e na compreensão dela através da leitura. O hemisfério direito, de sua parte, é melhor para a percepção de sons musicais e no reconhecimento de faces, especialmente quando se trata de aspectos gerais (homem ou mulher? adulto ou criança?). O hemisfério esquerdo também participa do reconhecimento de faces, mas sua especialidade é descobrir precisamente quem é o dono de cada face (José ou Joaquim?). Da mesma forma, o hemisfério direito é especialmente capaz de identificar categorias gerais de objetos e seres vivos (livros, cães), mas é o esquerdo que detecta as categorias específicas (um exemplar de Cem Bilhões de Neurônios, um pastor alemão). O hemisfério direito é melhor na detecção de relações espaciais, particularmente as relações métricas, quantificáveis, aquelas que são úteis para o nosso deslocamento no mundo (a que distância estou do carro da frente?). O hemisfério esquerdo não deixa de participar dessa função, mas é melhor no reconhecimento de espaciais categoriais qualitativas (acima de, abaixo de, dentro, fora...). Finalmente, não vamos esquecer as habilidades motoras: o hemisfério esquerdo produz movimentos mais precisos da mão e da perna direitas (na maioria das pessoas) do que o hemisfério direito é 
capaz de fazer com a mão e a perna esquerdas.

Talvez a principal generalização que se possa fazer dos estudos que revelaram que as especialidades funcionais dos hemisférios seja a de que o hemisfério direito comanda e percebe funções globais, categoriais, enquanto o hemisfério esquerdo se encarrega das funções mais específicas. De certo modo, essas diferentes especialidades se baseiam em diferentes estratégias de operação, que no final das contas podem ser devidas à segregação lateral de neurônios e circuitos com distintos modos de funcionamento.

Observe a (figura 19.20). Ela representa um quadro famoso do pintor espanhol Salvador Dalí. À primeira vista você identifica pessoas no centro da tela, observadas por uma mulher no primeiro plano à esquerda. As pessoas estão de pé em uma construção incompleta, e a mulher de torso nu se apóia em uma mesa com dois objetos. Essa descrição provavelmente Ihe basta para uma percepção global do quadro. Mas se você observar novamente com cuidado, o grupo de pessoas bem no centro subitamente se transforma em um rosto humano, o busto de Voltaire! É preciso um outro olhar para perceber isso.

Na observação do quadro de Dalí você utilizou duas estratégias de percepção: a primeira foi mais global, a segunda foi mais específica. Possivelmente o hemisfério direito participou mais da primeira estratégia, enquanto o esquerdo predominou na segunda. Evidências desses diferentes modos de operação dos hemisférios foram obtidas por psicólogos empregando estímulos lingüísticos ou pictóricos (figura 19.21) apresentados a pacientes com grandes lesões do hemisfério direito e outros do hemisfério esquerdo. Os pacientes eram solicitados a observar um estímulo e depois desenhá-lo numa folha de papel. Os que tinham apenas o hemisfério esquerdo funcionando viram os detalhes do estímulo, ou seja, os 
componentes miúdos da figura maior. O contrário ocorreu com os que tinham apenas o hemisfério direito funcionando: detectaram a configuração global, mas não os detalhes. Desse e de outros experimentos semelhantes surgiu a hipótese de que talvez predominem no hemisfério esquerdo neurônios detectores de freqüências espaciais, capazes de detectarem estímulos finos e pequenos. No hemisfério direito, predominariam detectores de freqüências espaciais mais baixas, melhores para perceber os estímulos maiores.

Além das assimetrias perceptuais e lingüísticas, as assimetrias comportamentais também refletem a especialização dos hemisférios œrebrais. De todas, a mais conhecida é a preferência manual.

A grande maioria dos seres humanos (95\% ou mais) é destra, ou seja, prefere utilizar a mão direita para as tarefas motoras de maior precisão. A minoria é de canhotos, e uma proporção muito pequena é constituída de ambidestros. Além da preferência manual, há uma preferência para uso dos pés, outra para uso dos olhos, e elas não estão necessariamente relacionadas. Da mesma forma, não parecem estar relacionadas a preferência manual e a lateralidade lingüística. É verdade que a maioria dos destros tem a linguagem representada no hemisfério esquerdo, mas a maioria dos canhotos também... Apenas uma proporção pequena dos canhotos tem a representação situada no hemisfério direito, e uma menor ainda na linguagem bilateral.

Muitos mamíferos (ratos, gatos, macacos) apresentam também preferência de uso de uma das patas em detrimento da outra. No entanto, na população a distribuição dessa assimetria é aleatória: metade dos indivíduos usa mais a pata esquerda, enquanto a outra metade prefere a pata direita.

A preferência manual humana reflete a diferença de estratégias 
funcionais dos hemisférios. Quando apontamos um lápis, por exemplo, usamos uma das mãos para segurá-lo (movimento de pequena precisão) e a outra para cortar a madeira com o canivete (movimento de maior precisão). A mão que segura o lápis é comandada pelo hemisfério direito (mesmo na maioria dos canhotos) e a mão que faz a ponta é comandada pelo hemisfério esquerdo. A diferença de estratégias para o comando manual é também evidenciada num fenômeno estranho que se observa em alguns indivíduos com o cérebro dividido: o conflito intermanual. Na ausência de comunicação entre os hemisférios, as mãos "não se estendem": iniciam movimentos opostos, à revelia do indivíduo. Uma das mãos pega uma caneta para escrever, mas a outra intercepta, retira a caneta e a coloca de volta sobre a mesa!

Uma dificuldade para o estudo da determinação neurobiológica das assimetrias comportamentais é que elas são suscetíveis a influências ambientais. Os jogadores de futebol, por exemplo, podem ser treinados a utilizar os dois pés para chutar, embora originalmente prefiram utilizar um deles. As crianças canhotas de antigamente muitas vezes tornavam-se destras, forçadas pelos pais, que acreditavam ser a mão direita necessariamente mais hábil e precisa que a esquerda."

(LENT, 2004; p.642- 646) 


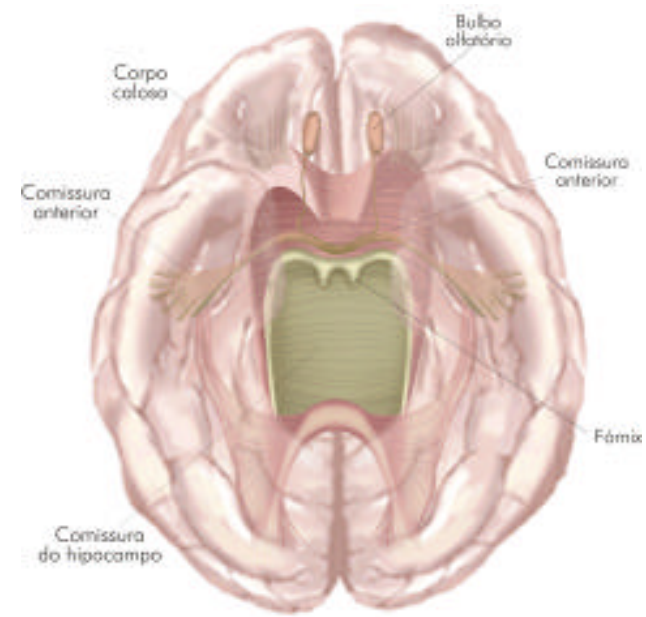

tigura $7 y .71$
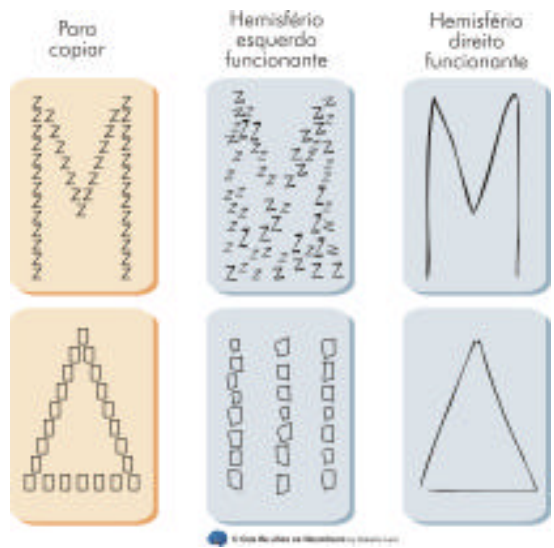

figura 19. 21
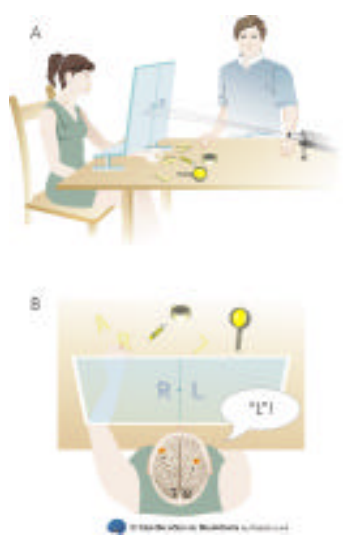

figura 19. 18

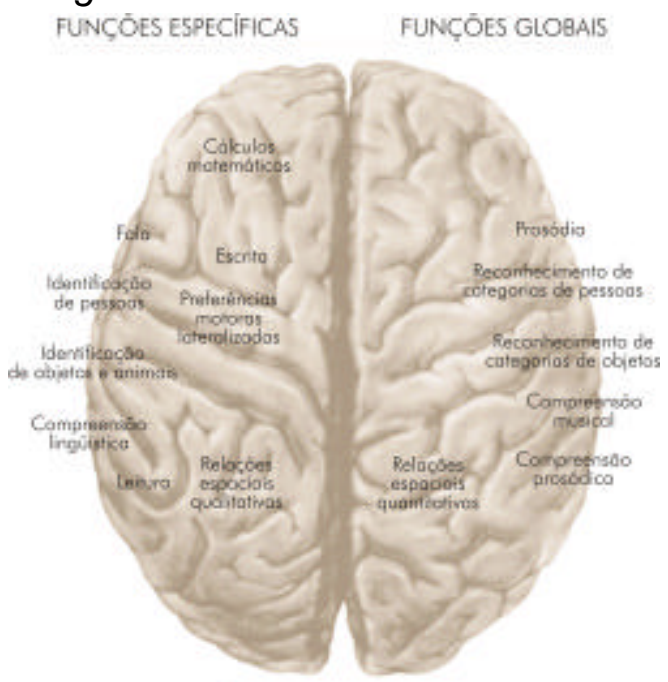

figura 19. 19

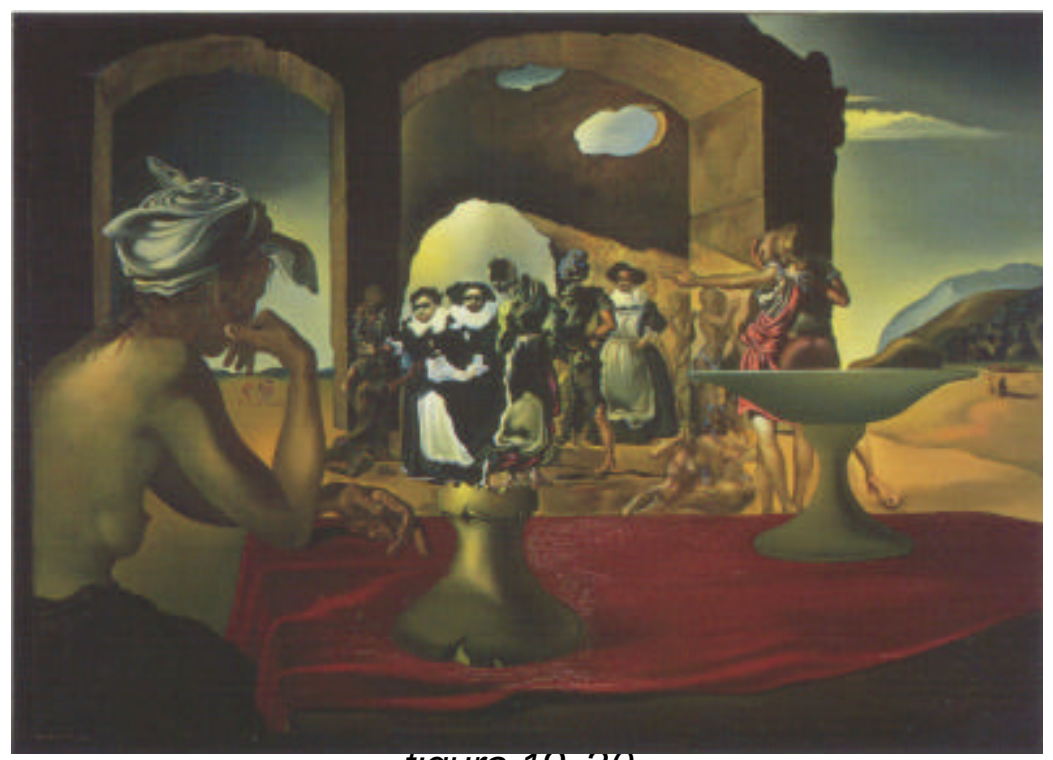

tigura 19.20 


\section{A Psicologia Experimental e AS TeORIAS dA Gestalt}

No ensaio que deu à Teoria da Gestalt seu nome, Christian von Ehrenfels, filósofo vienense do fim do séc XIX, demonstrou que, se 12 observadores escutassem cada um dos 12 tons de uma melodia, a soma de suas experiências não corresponderia à experiência de alguém que a ouvisse inteira. Portanto, o todo é diferente da soma das partes e estas não podem fornecer uma real compreensão do todo.

Considerando estes argumentos filosóficos, Max Wertheimer (18801943), Kurt Kofka (1886-1937) e Wolfgang Köhler (1887-1967), em Universidades da Alemanha, dão início a uma sistemática investigação científica para realizar a comprovação experimental desta afirmação filosófica.

Os resultados desta pesquisa são pulicados em 1912, por Max Wertheimer, em artigo que descrevia o experimento que haviam realizado para explorar certos aspectos da percepção do movimento. Numa sala escura, fizeram reluzir em rápida sucessão dois pontos de luz próximos um do outro, variando os intervalos de tempo entre os clarões. Descobriram que, quando o intervalo entre os clarões era menor que 3/100 de segundo, eles pareciam simultâneos. Quando o intervalo era de 6/100 de segundo, o observador dizia ver o clarão mover-se do primeiro ponto ao segundo. Quando o intervalo era de 20/100 de segundo ou mais, os pontos de luz foram observados como o eram de fato, ou seja, dois clarões de luz separados.

A descoberta crucial do experimento refere-se à percepção de movimento quando os clarões estavam separados por aproximadamente 6/100 de segundo. O movimento aparente não era função dos estímulos isoladamente, mas 
dependia das características relacionadas à organização neural e perceptiva do campo. Os resultados deste experimento levaram a algumas reformulações fundamentais no estudo da percepção, durante as décadas de 1920 e 1930 do século $X X$.

A partir da publicação desse artigo, estava implantada a Gestalt ${ }^{34}$ como Escola de Psicologia Experimental. Por volta de 1933, refugiando-se do nazismo, os três pesquisadores emigram para os Estados Unidos. Lá aturam em Universidades distintas, influenciando, difundindo e ramificando a psicologia da gestalt.

A psicologia da gestalt ${ }^{35}$, após sistemáticas pesquisas, apresenta uma teoria nova sobre o fenômeno da Percepção. Segundo esta teoria, o que acontece no cérebro não é idêntico ao que acontece na retina. A excitação cerebral não se dá por pontos isolados, mas por extensão. A primeira sensação já é de forma, já é global e unificada.

O postulado da psicologia da gestalt no que se refere às relações psicofisiológicas pode ser definido como sendo todo o processo consciente, toda forma psicológicamente percebida, e está estreitamente relacionada com as forças integradoras do processo fisiológico cerebral. A hipótese da gestalt para explicar a origem dessas forças integradoras, é atribuir ao sistema nervoso central um dinamismo auto-regulador que, à procura de sua própria estabilidade, tende a organizar as formas em todos coerentes e unificados.

Essas organizações, originárias da estrutura cerebral, são espontâneas, não arbitrárias e independem da vontade.

\footnotetext{
${ }^{34}$ A palavra Gestalt, de origem alemã, é um substantivo comum usado para configuração ou forma. O sentido mais geral que se pode dar ao termo seria uma espécie de disposição ou configuração de uma organização específica das partes que constituiria um todo particular.

${ }^{35}$ É importante não confundir a Psicologia da Gestalt e as teorias da gestalt com a Gestalt Terapia, estruturada por Frederick Perls.
} 


\section{Leis da Gestalt}

As leis de organização da Gestalt têm guiado os estudos sobre como as pessoas percebem componentes visuais como padrões organizados ou conjuntos, ao invés de suas partes componentes. De acordo com essa teoria, há oito fatores principais que determinam como nós agrupamos coisas de acordo com a percepção visual. Os teóricos da Gestalt propuseram uma série de princípios para percepção, tais como: proximidade, semelhança, continuidade, fechamento, unificação, segregação, unidade e pregnância da forma.

\section{A utilização das leis da Gestalt na sintaxe visual}

A partir das leis da gestalt, foi criado o suporte sensível e racional, espécie de abc da leitura visual, que permitiu e favoreceu toda e qualquer articulação analítica e interpretativa de forma do objeto, sobretudo com relação à utilização das demais categorias conceituais. A seguir, são colocados os rebatimentos operados sobre as leis da Gestalt, que dão embasamento científico a este sistema de leitura visual:

a. Unidade - Uma unidade pode ser consubstanciada num único elemento, que se encerra em si mesmo, ou como parte de um todo. Ainda, numa conceituação mais ampla, pode ser entendida como o conjunto de mais de um elemento, configurando o "todo" propriamente, ou seja, o próprio objeto.

$\checkmark$ As unidades formais que configuram um todo são percebidas, geralmente, através de relações entre os elementos (ou subunidades) que as constituem. Uma ou mais unidades formais 
podem segregadas ou percebidas dentro de um todo por meio de diversos elementos, tais como: pontos, linhas, planos, volumes, cores, sombras, brilhos, texturas e outros, isolados ou combinados entre si.

b. Segregação - Segregação significa a capacidade perceptiva de separar, identificar, evidenciar ou destacar unidades formais em um todo compositivo ou em partes deste todo. Naturalmente, pode-se segregar uma ou mais unidades, dependendo da desigualdade dos estímulos produzidos pelo campo visual (em função das forças de um ou mais tipos de contrastes).

$\checkmark$ A segregação pode ser feita por diversos meios, tais como: elementos dos pontos, linhas, planos, volumes, cores, sombras, brilhos, texturas e outros. Para efeito de leitura visual, pode-se também estabelecer níveis de segregação. Por exemplo, identificando-se apenas as unidades principais de um todo mais complexo, desde que seja suficiente para o objetivo desejado de análise e/ou interpretação da forma do objeto.

c. Unificação - A unificação da forma consiste na igualdade ou semelhança dos estímulos produzidos pelo campo visual, pelo objeto. A unificação se verifica quando os fatores de harmonia, equilíbrio, ordenação visual e, sobretudo, a coerência da linguagem ou estilo formal das partes ou do todo estão presentes no objeto ou composição. Importante salientar que, obviamente, a unificação se dá também em graus de qualidade, ou seja, varia em função de uma 
melhor ou pior organização formal.

$\checkmark$ Nesse caso se poderá atribuir índices qualitativos numa dada leitura. Em tempo, dois princípios básicos concorrem também fortemente para a unificação da organização formal, que são as leis de proximidade e semelhança quando presentes em partes ou no objeto como um todo.

d. Fechamento - O fator de fechamento é importante para a formação de unidades. As forças de organização da forma dirigem-se espontaneamente para uma ordem espacial que tende para a formação de unidades em todos fechados. Em outras palavras, obtém-se a sensação de fechamento visual de forma pela continuidade numa ordem estrutural definida, ou seja, por meio de agrupamento de elementos de maneira a constituir uma figura total mais fechada ou mais completa. Importante não confundir a sensação de fechamento sensorial, de que trata a lei da Gestalt, com o fechamento físico, contorno dos elementos dos objetos, presente em praticamente todas as formas dos objetos.

e. Continuidade - A boa continuidade, ou boa continuação, é a impressão visual de como as partes se sucedem através da organização perceptiva da forma de modo coerente, sem quebras ou interrupções na sua trajetória ou na sua fluidez visual. É também a tendência dos elementos de acompanharem uns aos outros, de maneira tal que permitam a boa continuidade de elementos como: 
pontos, linhas, planos, volumes, cores, sombras, brilhos, degradês e outros. Ou de um movimento numa direção já estabelecida. A boa continuidade atua ou concorre, quase sempre, no sentido de se alcançar a melhor forma possível do objeto, a forma mais estável estruturalmente.

f. Proximidade - Elementos ópticos próximos uns dos outros tendem a ser vistos juntos e, por conseguinte, a constituírem um todo ou unidades de um todo. Em condições iguais, os estímulos mais próximos entre si, seja por forma, cor, tamanho, textura, brilho, peso, direção e outros, terão maior tendência a serem agrupados e a constituírem unidades. Proximidade e semelhança são dois fatores que, muitas vezes, agem em comum e se reforçam mutuamente, tanto para constituírem unidades como para unificar a forma.

g. Semelhança - A igualdade de forma e de cor desperta também a tendência de se constituir, isto é, de estabelecer agrupamentos de partes semelhantes. Em condições iguais, os estímulos mais semelhantes entre si, seja por forma, cor, tamanho, direção, e outros, terão mais tendência a serem agrupados, a constituírem partes ou unidades. Em condições iguais, os estímulos originados por semelhança e em maior proximidade terão também maior tendência a serem agrupadaos, a constituírem unidades. Semelhança e proximidade são dois fatores que, além de concorrerem para a formação de unidades, concorrem também para 
promoverem a unificação do todo, daquilo que é visto, no sentido de harmonia, ordem e equilíbrio visual.

h. Pregnância da Forma - A pregnância é a Lei Básica da Percepção Visual de Gestalt e assim definida: "Qualquer padrão de estímulo tende a ser visto de tal modo que a estrutura resultante é tão simples quanto perimitam as condições dadas [...] As forças de organização da forma tendem a se dirigir tanto quanto o permitam as condições dadas, no sentido da harmonia e do equilíbrio visual". (FILHO, 2000)

$\checkmark$ Continuando, uma boa pregnância pressupõe que a organização formal do objeto, no sentido psicológico, tenderá a ser sempre a melhor possível do ponto de vista estrutural. Assim, para efeito desse sistema, pode-se afirmar e estabelecer o seguinte critério de qualificação ou julgamento organizacional de forma:

i. Quanto melhor for a organização visual da forma do objeto em termos de facilidade de compreensão e rapidez de leitura ou interpretação, maior será o seu grau de pregnância.

$\checkmark$ Naturalmente, quanto pior ou mais confusa for a organização visual da forma do objeto, menor será o seu grau de pregnância. Para facilitar o julgamento da pregnância, pode-se estabelecer um grau ou índice de pontuação como, por exemplo: baixo, médio, alto, ou ainda uma nota de 1 a 10 , respectivamente, no sentido da melhor para a pior qualificação. 


\title{
II SANTIAGO RAMÓN Y CAJAL
}

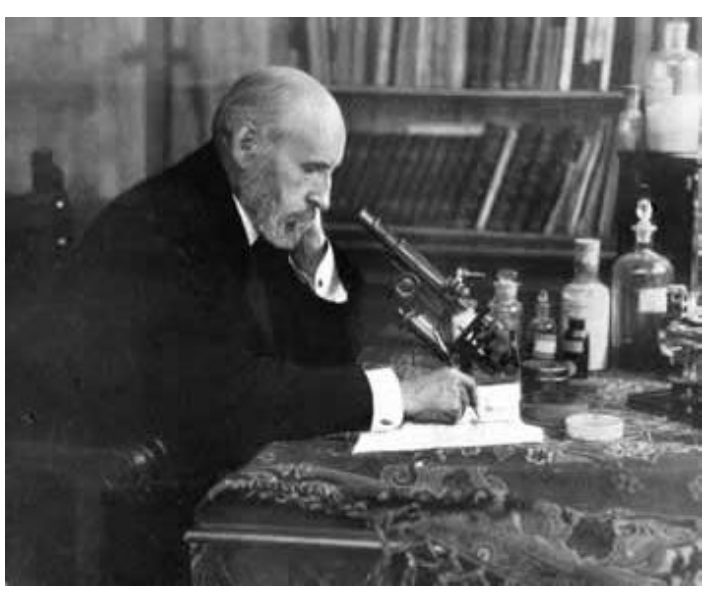

\author{
SANTIAGO RAMÓN Y CAJAL \\ "No soy en realidad un sabio sino un \\ español."
}

Santiago Ramón y Cajal nasceu em 1ํ de maio de 1852 em Petilla de Aragón, uma pequena vila ao norte da Espanha, e faleceu no dia 17 de outubro de 1934 em Madrid, aos 82 anos. É considerado o pai da neurociência moderna, pois seus estudos constituem, até os dias atuais, a base do conhecimento neste campo.

Graduou-se na Faculdade de Medicina em Zaragoza em 1873, aos 21 anos. Em seguida, ingressou no Exército Espanhol, servindo como médico em Cuba, onde contraiu malária e tuberculose, retornando à Espanha em 1875. Em 1877 obteve o grau de Doutor em Medicina, em Madrid, passando a lecionar Histologia em Zaragoza e depois assumindo a direção do Museu de Anatomia.

Em 1879 casou-se com Silveria Fañanás García, sua companheira de toda a vida, com quem teve sete filhos.

“Hay pocos lazos de amistad tan fuertes que no puedan ser cortados por um cabello de mujer"

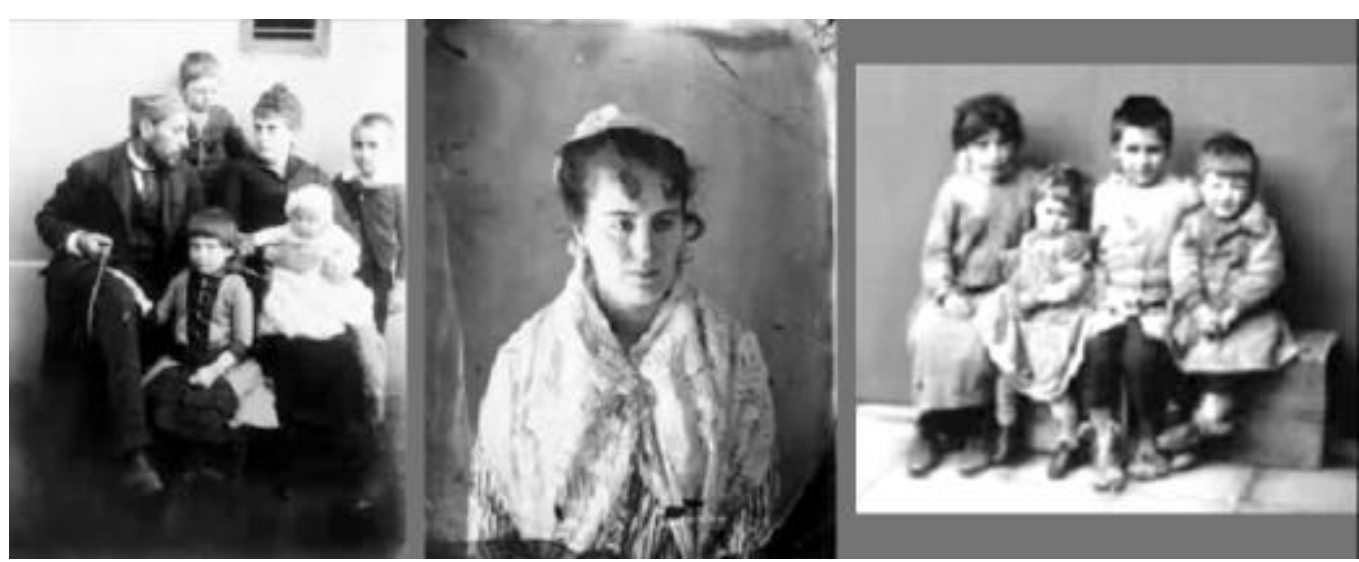

Lecionou Anatomia em Valência (1883), Histologia em Barcelona (1887), assumiu a disputada Cátedra de Histologia em Madrid (1892) e dirigiu o Laboratório de 
Investigação Biológica (1901), que constituiu o embrião do atual Instituto Cajal, um dos maiores centros de Neurociência do mundo.

Cajal permaneceu em intensa atividade científica até 1932, quando se aposentou, aos 80 anos de idade. Entre 1933 e 1934, lançou suas duas últimas obras; Neuronismo o reticularismo? e um livro de memórias El mundo visto a los ochenta años.

"El arte de vivir mucho es resignarse a vivir poco a poco"

\section{O DESENHO, A PINTURA , A FOTOGRAFIA E A MICROGRAFIA}

“...eu estava com oito ou nove anos e tinha uma irresistível vontade de desenhar, de colorir as paredes recém pintadas da vila com todo tipo de desenhos, cenas militares e touradas... mas como não podia desenhar em casa, pois meu pai considerava o desenho uma distração nefasta... saía ao campo... e desenhava cavalos, carretas, vilarejos e paisagens que me parecessem interessantes... e que guardava como ouro em pó... traduzindo meus sonhos no papel, tendo meu lápis como uma varinha mágica, eu criei o mundo que desejei, habitado por todas aquelas coisas que nutriam meus sonhos... tudo passava através de meu lápis agitado." Ramón y Cajal, Recuerdos de mi vida.
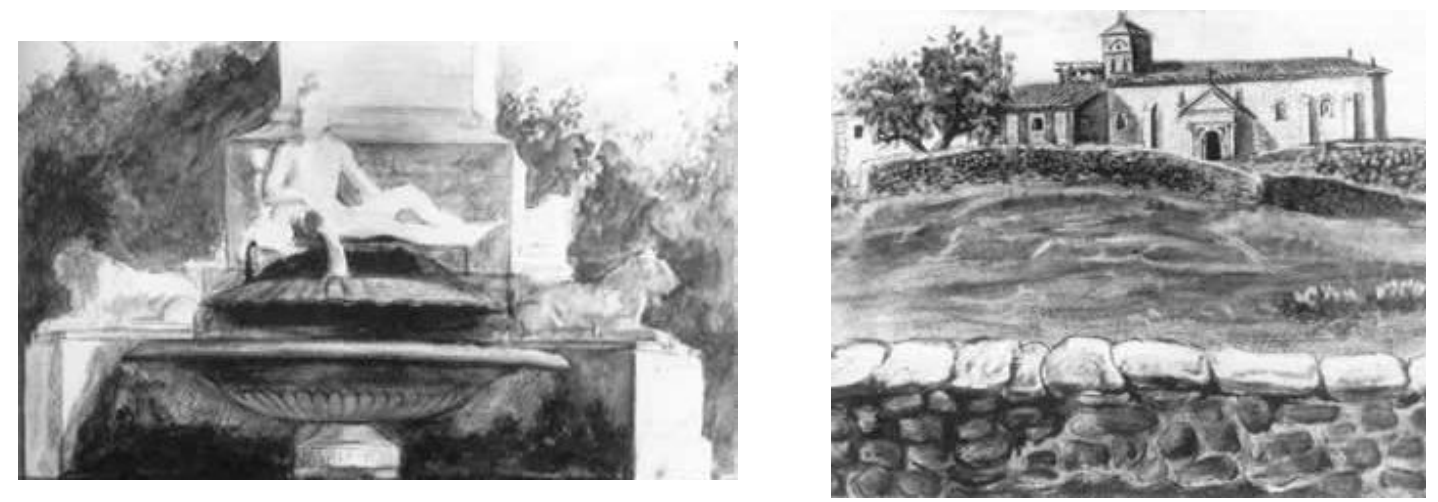

"Nos desdeñamos u odiamos porque no nos comprendemos porque no nos tomamos el trabajo de estudiarnos." 
Embora desenhasse com freqüência, sua desenvoltura ainda não the satisfazia. Ao estudar em Huesca (1861), Cajal recebeu aulas de desenho e pintura, podendo assim aprimorar sua técnica, tornando-se um aluno talentoso.

Quando Cajal se formou em medicina, a micrografia desenvolvida naquele tempo não tinha uma boa resolução e, virtualmente, a única maneira de ilustrar as observações era por meio dos desenhos, que estavam abertos ao ceticismo.

Alguns dos desenhos de Cajal foram considerados como interpretações artísticas melhores que cópias exatas de suas preparações e estão

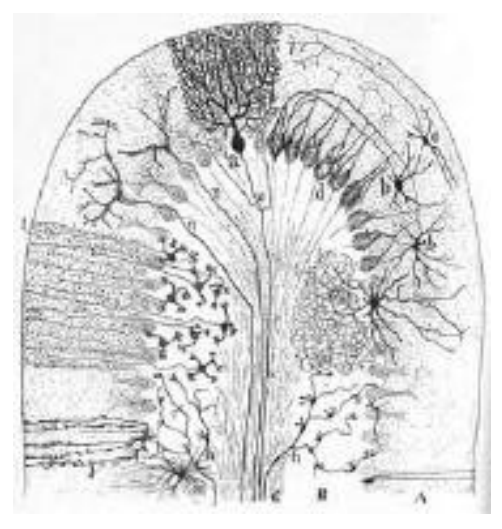
abrigadas no Museu de Cajal, no Instituto de Cajal, em Madrid.

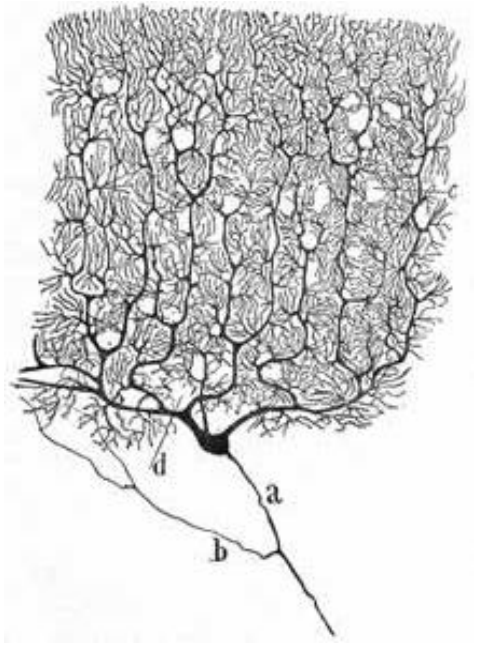

Ao aliar arte e ciência, Cajal, sem sabê-lo, adquiriu uma competência que o levaria à formulação da sua Teoria Neuronal alguns anos mais

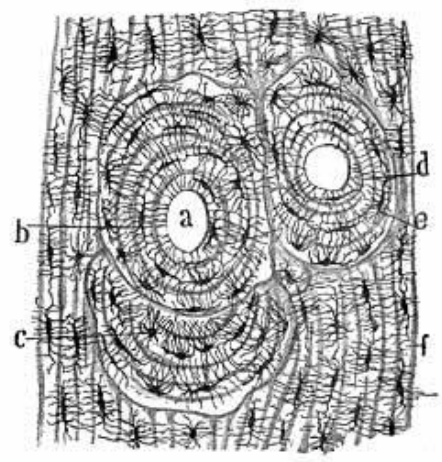
tarde.

"O que distinguiu Cajal de seus contemporâneos foi sua capacidade de superar a descrição anatômica. Ele tinha capacidade de olhar para a estrutura estática _ uma secção anatômica no microscópio_e obter noções sobre o seu funcionamento."

Eric Kandel 


\section{"Los débiles sucumben, no por ser débiles, sino por ignorar que lo son."}

Em 1870, desenhou o Álbum Anatômico. Este álbum, unido às centenas de desenhos científicos, tornourse referência no meio científico e um verdadeiro legado ao mundo das artes.

"Razonar y convencer, iqué difícil, largo y trabajoso! ¿Sugestionar? ¡Qué fácil, rápido y barato!”

"En el orden de investigaciones en que vamos a entrar procuraremos ante todo ser fieles intérpretes de los hechos, y no imponer a la naturaleza nuestros prejuicios, sujetándola al estrecho molde de nuestras concepciones. Aspiremos a comprender la organización tal cual es, no como quisiéramos que fuera; achaque general del espiritu humano, que tiende siempre a contemplar en las obras de la naturaleza una imagen de su propia inteligencia". Historia de mi labor, Ramón y Cajal, 1905.
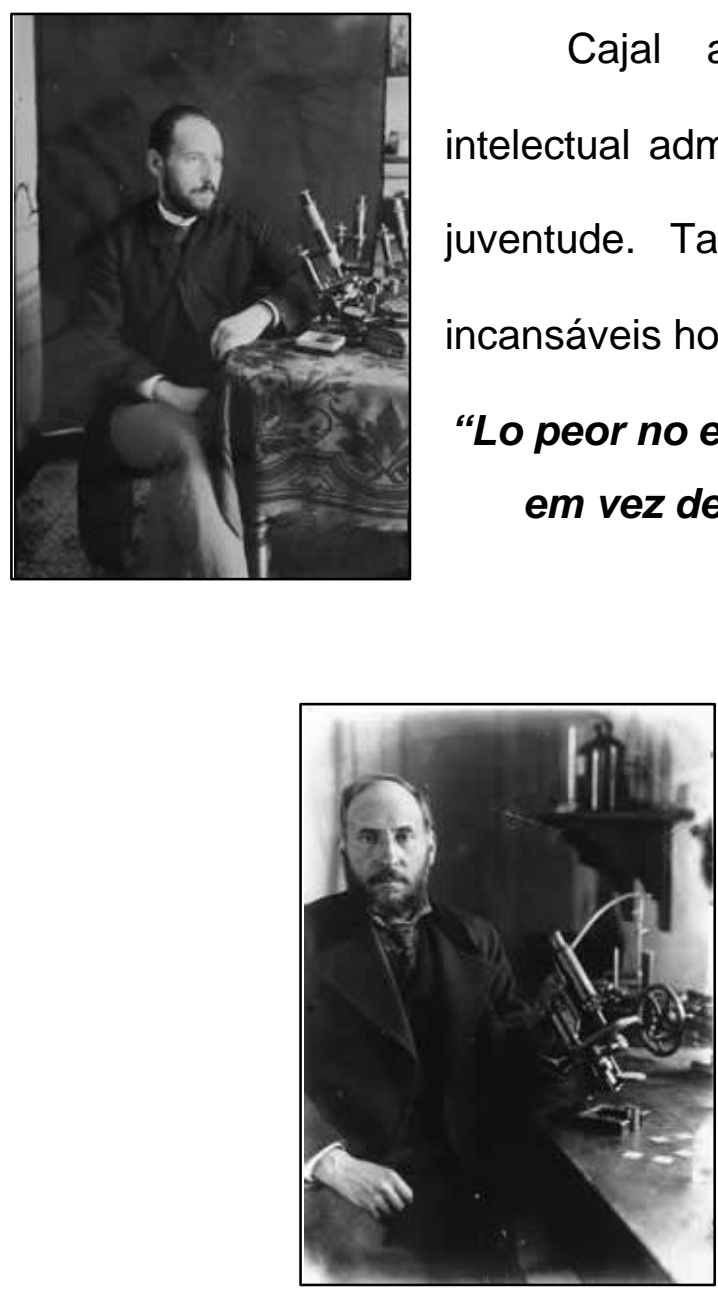

Cajal apreciava a filosofia, tinha uma disciplina intelectual admirável e um hábito por exercício físico desde a juventude. Tais predileções auxiliaram as suas longas e incansáveis horas de observação ao microscópio.

"Lo peor no es cometer um error, sino tratar de justificarlo, em vez de aprovecharlo como aviso providencial de nuestra ligereza o ignorancia."

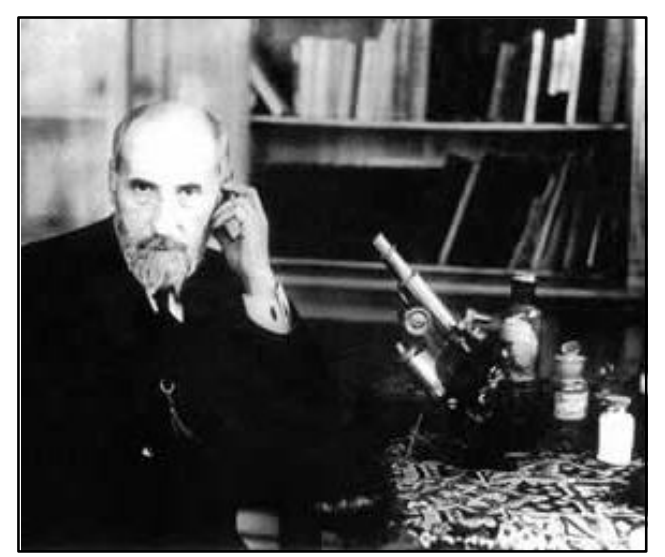




\title{
CAJAL E A FOTOGRAFIA
}

A sensibilidade artística de Cajal o levou a introduzir-se no mundo da Fotografia em Huesca (1868).

Com seu interesse pela arte de reproduzir imagens e sua dedicação constante, em 1883, aplicou a fotografia à gravura pela primeira vez na Espanha, realizando as chamadas Fotos Litográficas. Seu prestígio foi tão grande que, em 1900, foi nomeado Presidente Honorífico de la Real Sociedad Fotografica de Madrid. Em 1912 publicou o livro La fotografia de los colores. Seu interesse pela fotografia não foi unicamente circunstancial. Assim, anos mais tarde chegou, inclusive, a fabricar emulsões para placas fotográficas, criando um pequeno negócio, que mesmo com êxito não levou adiante.

\section{PRÊMIO NOBEL DE FISIOLOGIA E MEDICINA - 1906}

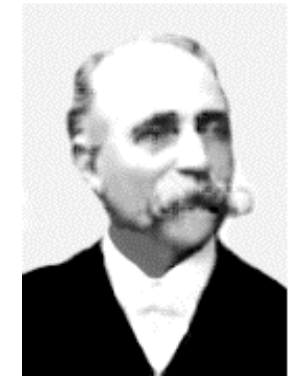

\section{Camillo Golgi}

(1843 - 1926)

\author{
Ramón y Cajal \\ $(1852$ - 1934)
}

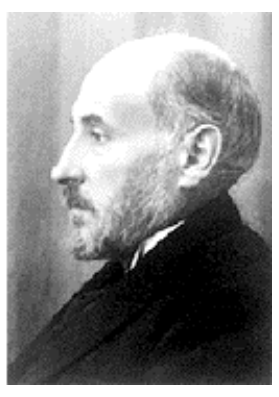

O estudo detalhado do sistema nervoso teve início no século XIX. Antes das descobertas de Cajal, os conhecimentos sobre a estrutura individual do sistema nervoso e as conexões entre os neurônios eram puramente especulativos. Essa falta de conhecimento era principalmente devido ao fato de que os métodos existentes para visualizar os neurônios não eram apropriados ou mesmo disponíveis. Entretanto, em 1873, Camillo Golgi desenvolveu um método que, pela primeira vez, tornava possível observar os neurônios em sua totalidade em preparações histológicas: soma (corpo), dendritos e axônios. Dessa forma, os neurônios marcados com o método de Golgi indicaram os seus detalhes morfológicos refinados, e conduziram, finalmente, à sua caracterização e classificação, bem como ao estudo de suas possíveis conexões, feito por Cajal. 


\section{"para ser fuerte hay que luchar com los fuertes."}

Cajal conheceu o método de Golgi em 1887. Isso trouxe mudança radical em sua carreira científica, inclusive em suas descrições do sistema nervoso, que passaram a ser baseadas em suas observações com a utilização do método de Golgi. O livro clássico "Histology of the Nervous System" contém a síntese desses estudos, sendo ainda um livro de referência em todos os laboratórios do neurociências.

Durante esse período de intensas observações, Cajal encontrou muitas evidências que favoreceram a teoria da "Doutrina neuronal", que contrastou com o outro princípio que prevalecia na época, a "Teoria reticular".

A teoria reticular continha a idéia de que o sistema nervoso era constituído por uma rede difusa de neurônios e que suas fibras eram anastomosadas. Cajal propôs, então, que o princípio organizacional e funcional fundamental do sistema nervoso é o neurônio. Além disso, comprovou que a comunicação entre os neurônios se dá por contigüidade e não por continuidade, como estudiosos afirmavam, terminando assim com a teoria reticularista. Assim, surge a forma de conexão entre os neurônios, conhecida hoje como sinapse.

Por todos esses feitos, em 1906, foi concedido o prêmio Nobel de Fisiologia ou Medicina para Golgi, por descobrir a técnica com nitrato de prata e Cajal compartilhou o prêmio Nobel por suas brilhantes interpretações, bem elaboradas, das preparações do sistema nervoso com esse método.

"La gloria, em verdad, no es outra cosa que um olbido aplazado." 


\section{NFLUÊNCIA DE CAJAL NA DIVULGAÇÃO DA CIÊNCIA}

\section{“¿No tienes enemigos? ¿Es que jamás dijiste la verdad o jamás amaste la justicia?"}

Cajal, em um dos seus discursos, falou e se auto-avaliou: "No soy en realidad un sabio, sino un patriota; tengo más de obrero infatigable que de arquitecto calculador... La Historia de mis méritos es muy sencilla: es la vulgarísima historia de una voluntad indomable resuelta a triunfar a toda costa... Mi fuerza fue el sentimiento patriótico; mi norte, el enaltecimiento de la toga universitaria; mi ideal aumentar el caudal de ideas españolas circulantes por el mundo, granjeando respeto y simpatía para nuestra ciencia..."Ramón y Cajal, Recuerdos de mi vida.

"Se conocen infinitas clases de necios; la más deplorable es la de los parlanchines empeñados en demostrar que tienen talento."

O mestre, ao completar seus 70 anos, deixou a cátedra da Universidade de Madrid, à qual se dedicou durante 30 anos. Por isso, uma das maiores homenagens da sua vida foi o grande livro "El Libro Homenaje a Cajal", constituído por trabalhos científicos e feitos honoríficos, firmados pelos mais representativos cientistas do mundo, tais como: Sherrington, Von Monarold, P. Marie, Lugaro, Marinesco, Houssay, Lewis, Kravs, P. Ramón (seu irmão), De Castro, Lafora, Ramón Fañanás, Pittaluga, entre outros.

Cajal manteve colaboração com diversos cientistas renomados, sendo sempre fiel a sua vida e sua obra científica. Essa multiplicidade integrativa, característica desenvolvida em sua personalidade, pontuou a sua fundamental influência e marco no saber neurocientífico.

Temos diante de nós um cientista espanhol que inseriu a Espanha na ciência européia, considerado mundialmente o Pai da Neurociência Moderna pelos seus feitos.

"Sólo son desgraciados el loco incapaz de escoger sus ensueños y el enfermo a quien el dolor impide soñar." 


\section{OBRA CIENTÍFICA E LITERÁRIA}

\section{"Cada hombre es escultor de su próprio cerebro."}

Cajal demonstrou sua vivacidade mental nas múltiplas facetas que desenvolveu. A literatura cultivada desde sua adolescência foi outro de seus talentos. À parte de ser um grande leitor, escreveu um bom número de livros não apenas científicos; inclusive três deles relatam suas memórias. A partir deles, penetramos em suas recordações e podemos mapear toda trajetória de seus

pensamentos, suas aspirações e suas realizações.

-Mi infancia y juventud, 1901.

- Cuentos de vacaciones (narraciones pseudocientíficas), 1905.

-Recuerdos de mi vida, 1917.

-Charlas de café. Pensamientos, anécdotas y confidencias, 1921

-Historia de mi labor científica, 1905.

- La fotografía de los colores. Bases científicas y reglas prácticas, 1912.

-El mundo visto a los 80 años. Impresiones de un arterioesclerótico, 1934.

\section{"De todas las reacciones posibles ante una injuria, la más hábil y económica es el silencio."}

"Como el entomólogo a caza de mariposas de vistosos matices, mi atención perseguía, en el vergel de la sustancia gris, células de formas delicadas y elegantes, las misteriosas mariposas del alma cuyo batir de alas, quién sabe si esclarecerá, algún día, el secreto de la vida mental". Ramón y Cajal, Recuerdos de mi vida.

Com seu "lirismo científico" como ele mesmo designava, inspirou a vocação científica de várias gerações. Trabalhou enormemente para a divulgação da ciência.

Disse em sua autobiografia: "dejando a un lado exageraciones de 
pensamiento e incorrecciones de forma, trasciende de ellas algo como un aroma confortador de confianza juvenil y de fe robusta en el progreso social y científico. Hallo también atrayente cierto sentimiento de curiosidad frescamente satisfecha, $y$ un fervor de pasión hacia el estudio de los arcanos de la vida, que en vano buscaríamos hoy en los escritos primerizos de la ponderada, ecuánime, circunspecta y financiera juventud intelectual"..

\section{"Nada me inspira más veneración y asombro que um anciano que sabe cambiar de opinión."}

O seu vasto acervo científico inclui obras como: Manual de Histología Normal y Técnica Micrográfica; Manual de Anatomía Patológica General, em 1890; Les nouvelles idées sur la fine anatomie des centres nerveux, em 1894; Textura del sistema nervioso del hombre y de los vertebrados, em 1897-1904; Die Retina der Wirbelthiere, em 1894.

Publicou seus valiosos trabalhos sobre a estrutura do sistema nervoso, incluindo ainda músculos e tecidos e assuntos sobre patologia geral em revistas científicas européias, o que destacava seu potencial e seu brilhantismo científico. Foi membro de várias sociedades científicas importantes da Itália, Alemanha, Portugal, Inglaterra, França, dentre outros países.

"El silencio de los envidiosos es el mejor elogio a que puede aspirar un autor."

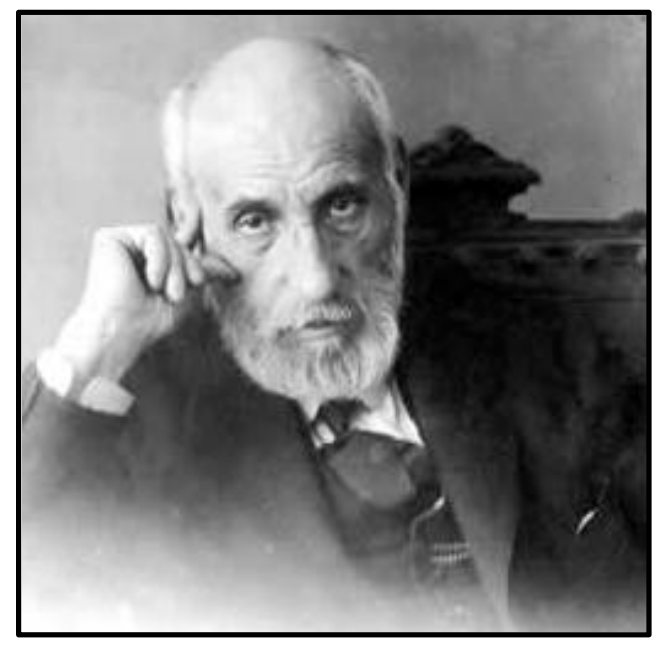




\section{LISTA DE ILUSTRAÇÕES}

Página 34: Salto de Ballet. Fonte: Aleksander Kurkov-Jean de Brienne. Raymonda, Mariinsky Theatre, 1994. Disponível em: <http://www.russiankonkurs.ru/eng/photo_video_archiv04.html>.

Salto de Paraquedas. Fonte: <http://www.mccallsmokejumpers.org/his tory/history.asp>.

Página 35: BMW Z4. Fonte: <http://www.fondochachi.com/Motor/Bmw/Bmw_Z4 Coupe.jpg>.

Página 39: Retrato de Leonardo da Vinci. Fonte: «www.ucmp.berkeley.edu/history/ images/vinci.gifs.

Página 50: Página do caderno de Leonardo:estudos da anatomia uterina e do feto. Fonte: <www.ucmp.berkeley.edu/history/images/vinci.gifs.

Mona Lisa - Fonte: <http://cv.uoc.es/ 991 0400501 web/fitxer/monali sa.jpg >.

Caderno vôo com asas - Fonte: <http://www.nitido.com/art/gallery/codex/ Articulated\%20Wing\%20-\%20Codex\%20Atlanticus.jpg>.

Última Ceia - Fonte: <http://www.salesianos.pt/images/notev/ultimaceia 251.jpg>.

Página 55: Violino. Fonte: Gazzaniga, 2006, p. 99.

Página 56: Corpo com nervos. Fonte: <http://www.corpohumano.hpg.ig.com.br/sist_ nervoso/sist_nervoso.html>.

Cerebro,cerebelo, tronco. Fonte: 丸ttp://www.msd.es/publicaciones/mm erck_hogar/seccion_06/seccion_06_059.html>.

Hemisférios cerebrais. Fonte: <http://www.public.iastate.edu/ design/ ART/NAB/brainb1.html>.

Página 57: Hemisferio e cabeça. Fonte: <http://www.public.iastate.edu/ design/ ART/NAB/brainb1.html>.

Lobos. Fonte: 丸ttp://www.msd.es/publicaciones/mmerck_hogar/seccion _06/seccion_06_059.html>. 
Página 59: Áreas e funções. Fonte: LENT, 2001 p. 290.

Neurônio. Fonte: <http://www.msd.es/publicaciones/mmerck_hogar/sec cion_06/seccion_06_059.html>.

Página 60: Transmissão sinaptica. Fonte: <http://www3.unisul.br/paginas/ensino/pos/ linguagem/0402/09.htm>.

Página 67: Sistema límbico. Fonte: <http://www.tsbvi.edu/Outreach/seehear/summer 05/smell.htm>.

Página 85: Cérebro vias visuais. Fonte: llustração adaptada a partir da Figura 1 de BALDO, 2003.

Página 91: M. Escher: Mão segurando espelho esférico. Fonte: <http://www.mces cher.com/>.

Assinatura de M. Escher. Fonte: <http://www.mcescher.com/>.

Página 92: O pensador, Rodin. Fonte: <http://www.musee-rodin.fr/welcome.htm>.

Página 96: Assinatura de Guimarães Rosa. Fonte: <http://www.releituras.com/ guima rosa_bio.asp>.

Página 108: Quadro da Memória, LENT, 2000.

Página 114: Ratinhos na gaiola. Fonte: <http://www.cerebromente.org.br/n11/mente/ eisntein/rats-p.html>.

Página 115: Gráfico, artigo Marion Diamond. Fonte: <http://www.cerebromente.org.br /n11/mente/eisntein/rats-p.html>.

Página 116: Ressonância Magnética. Fonte: 丸ttp://www.cerebromente.org.br/n11/ mente/eisntein/rats-p.html>.

Página 118: Quadro esquema evolutivo, lan Tarttesall. Fonte: <http://www.nws.it/chi siamo/testo/p_14.htm>.

Página 128: Escultura de cavalo. Fonte: <http://www.nature.com/news/2004/040705 /images/vogelherd.jpg>.

Escultura homem-leão. Fonte: <http://perso.orange.fr/coherence/pix/vo gelherd_250.jpg>.

Escultura Vênus. Fonte: <http://www.pantheon.org/areas/gallery/myth ology/other/willendorf_venus.jpg>. 
Página 129: Caverna de Chauvet. Fonte: <http://www.yale.edu/terc/democracy/may 1text/images/Chauvet\%20panorama.jpg.

Caverna de Chauvet. Fonte: 丸ttp://www.beyondbooks.com/art11/imag es/00013610.jpg>.

Página 133: Conchas. Fonte: <http://www.newscientist.com/data/images/ns/cms/ dn9392/dn9392-1_650.jpg >.

Sepultamento de Sungir. Fonte: <http://www.dominiosfantasticos.hpg.ig. com.br/sungirussian25k.jpg>.

Página 159 - 161: Cavalos. Fontes:

<http://www.rohdefineart.com/images/baronsw.jpg>.

<http://www.physics.udel.edu/ jlp/horselizwa.jpg>.

<http://us.geocities.com/xlgallery/IMG/hlebn-horse.gif>.

<http://www.dogonitgallery.com/horse/horse003.jpg>

<http://www.scifer.org/images/RunHrseCU.3-5-3.83.jpg>.

<http://www.kulacrosse.com/clipartstable/subs/standing/horse.gif>.

<http://www.artchive.com/artchive///leonardo/leonardo_rearing_horse.jpg>.

<http://www-img.fitzmuseum.cam.ac.uk/img/pdp/pdp2/PD.121-1961.jpg>.

<http://www.tarpits.org/education/guide/art/page13a.jpg>.

$<$ http://www.rpi.edu/ brownm/horse-horse.jpg>.

<http://members.tripod.com/ran_venice/images/davinci_a\%20rider\%20on\%20a\%20r earing\%20horse.jpg>.

Página 217: Especealização hemisférica. Fonte:

LENT,2000, p 646

Página 225 - 233: Fotos e desenhos de Ramón y Cajal. Fonte:

$<$ http://www.aragob.es/culytur/rcajal/escuela.htm> 
